\title{
ANALYSIS OF NATURAL GAS CONSUMPTION AND ENERGY SAVING MEASURES FOR POWDER COATING AND FOOD PROCESSING COMPANIES IN THE GREATER TORONTO AREA (GTA)
}

\author{
By \\ Md Maniruzzaman Akan \\ M.Eng (Industrial and Production Engineering) \\ Bangladesh University of Engineering and Technology, Dhaka, 2002
}

\begin{abstract}
A thesis
presented to Ryerson University

in the partial fulfillment of the requirements for the degree of

Master of Applied Science

in the program of Mechanical and Industrial Engineering
\end{abstract}

Toronto, Ontario, Canada, 2015

(C) Md Maniruzzaman Akan, 2015 


\section{AUTHOR'S DECLARATION FOR ELECTRONIC SUBMISSION OF A THESIS}

I hereby declare that I am the sole author of this thesis. This is a true copy of the thesis, including any required final revisions, as accepted by my examiners.

I authorize Ryerson University to lend this thesis to other institutions or individuals for the purpose of scholarly research.

I further authorize Ryerson University to reproduce this thesis by photocopying or by other means, in total or in part, at the request of other institutions or individuals for the purpose of scholarly research.

I understand that my thesis may be made electronically available to the public. 


\title{
ANALYSIS OF NATURAL GAS CONSUMPTION AND ENERGY SAVING MEASURES FOR POWDER COATING AND FOOD PROCESSING COMPANIES IN THE GREATER TORONTO AREA (GTA)
}

\author{
Md Maniruzzaman Akan \\ Master of Applied Science \\ Department of Mechanical and Industrial Engineering \\ Ryerson University, Toronto, Ontario, Canada, 2015
}

\begin{abstract}
Small and medium industries (SMEs) savings analysis and meaningful performance indicators can help Enbridge Gas Distribution Inc., and individual SMEs make effective decisions to improve facility performance. For this study, information on 11 SMEs' energy consumption has been provided. This entails: preliminary benchmarking, separation of process and seasonal energy consumption, heating degree days, individual facilities owned reference temperature, normalized annual energy consumption, normalized process and seasonal energy consumption, oven energy consumption, energy balance of oven, energy intensity of oven, and non-productive energy consumption. The most appropriate performance indicator is energy intensity of oven-in bake ovens, cure ovens, and dry-off ovens. The results observed energy intensity in terms of natural gas consumption of bake ovens are from $24 \mathrm{~m}^{3} / \mathrm{ft}^{3}$ to $30 \mathrm{~m}^{3} / \mathrm{ft}^{3}$, where the intensity of ovens with finishing process companies are from $8 \mathrm{~m}^{3} / \mathrm{ft}^{3}$ to $36 \mathrm{~m}^{3} / \mathrm{ft}^{3}$. Potential natural gas savings from the facilities processing powder coating and baking are $19 \%$ to $53 \%$ of total oven energy consumption by reducing exhaust energy loss. In the same study observed in analyzing production scheduling, that $8 \%$ to $69 \%$ of energy consumption can be saved by proper shutdown operation and scheduling.
\end{abstract}




\section{Acknowledgements}

Special thanks to my supervisor, Dr. Alan S Fung, P.Eng., FCSME, Department of Mechanical and Industrial Engineering, who gave me the opportunity to further my education and contributed to my program, thesis, and academic goals.

This would not have been possible without Alan's guidance, support, and trust in my personal work and innovation, and the opportunity he offered me to further my passion for industrial energy savings analysis beyond the university walls.

I would like to thank and acknowledge Paul Morrison, P.Eng. CEM, Energy Solution Consultant, Industrial Sector, Enbridge Gas Distribution Inc. and Peter Goldman, P.Eng. CEM, Energy Solution Consultant for their help and support. I would also like to acknowledge all funding partners: Enbridge Gas Distribution Inc., Connect Canada, and OCE Talent Edge.

I would like to thank Farzin Rad and Altamash Baig for their support in arranging energy audits and educating me in energy analysis calculation.

I would like to thank my fellow project partner, Tamima Ahmed, for her support in energy auditing, data collection, and the preparation of Excel-based calculating tools.

I give my immense appreciation, love, and sincere thanks to my parents and my wife for their unconditional support, love, and encouragement during my study. I would also like to thank my sons for sacrificing their summer tours due to my research work. Last but not least, I would like to thank my present supervisor Amanda Martin, CEM and Director, Sustainability Department, Graham Seaman, P.Eng., LEED AP, CEM of the City of Markham for their constant support and sacrifice by sparing me during the city's busy schedule. 


\title{
Dedication
}

\author{
My mother - Anwara Begum \\ My father - A K Abdul Mannan Akan \\ My wife - Ishrat Begum \\ My Son - Mubituzzaman Samir \\ My Son - Sabit bin Zaman
}




\section{Table of Contents}

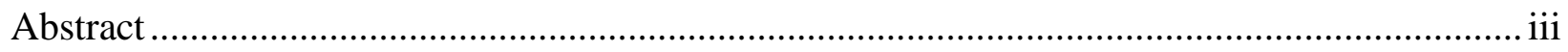

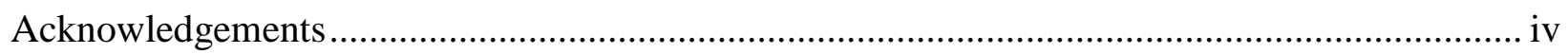

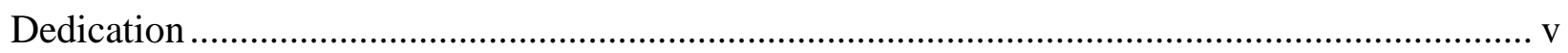

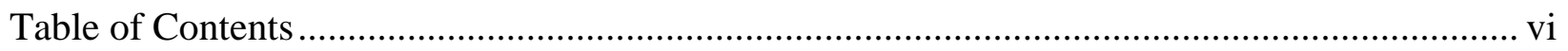

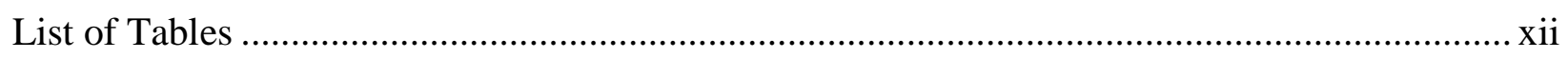

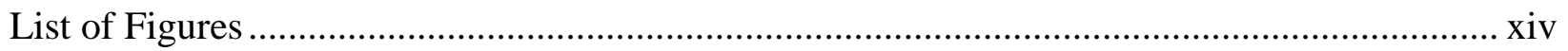

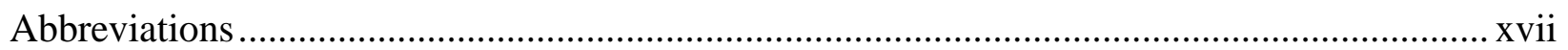

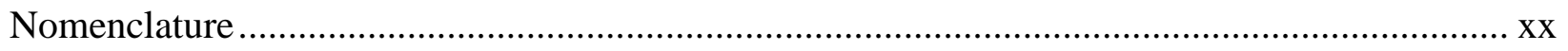

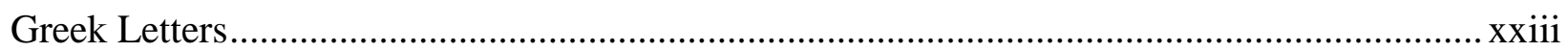

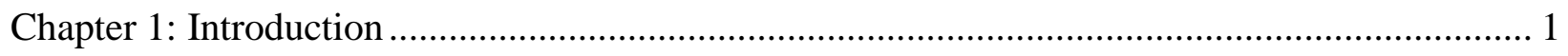

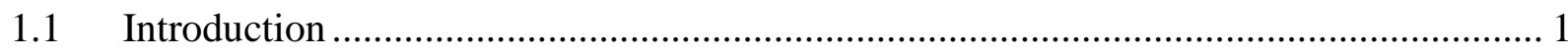

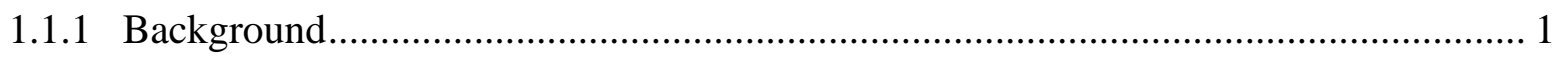

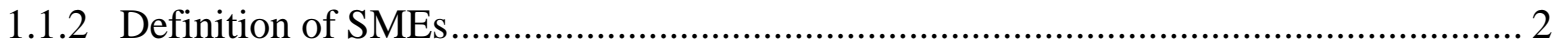

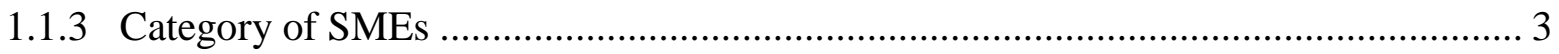

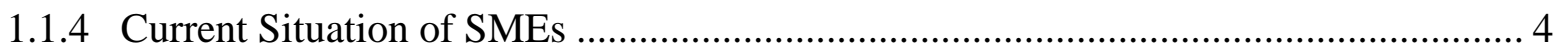

1.1.5 Benefits of SME Energy Management and Savings Programs .............................. 5

1.1.6 Barriers to Implementing Energy-Saving Programs ........................................... 6

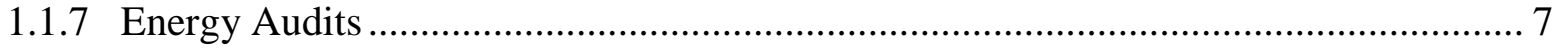

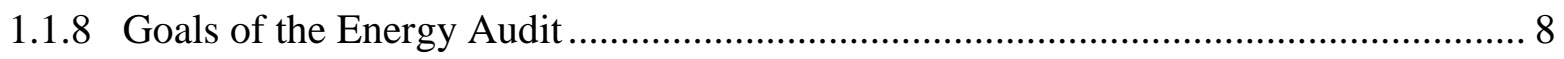

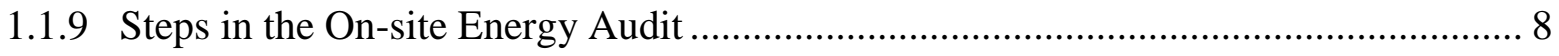

1.1.10 Equipment List for Energy Audit ........................................................ 9

1.1.11 Major Systems to Consider for Energy Audit............................................... 9 
1.1.12 Difference Between Energy Audit, Energy Conservation, and Energy Efficiency 10

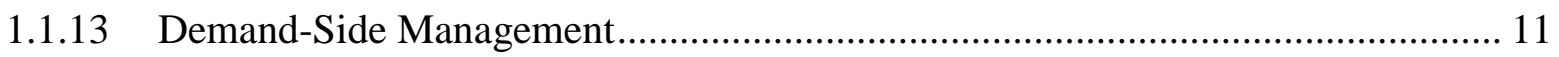

$1.2 \quad$ Energy Management Plan and Related Code ………….......................................... 12

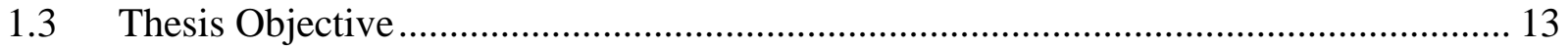

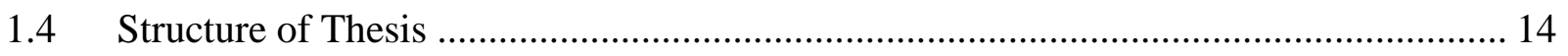

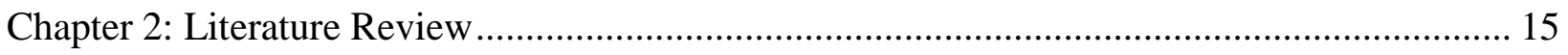

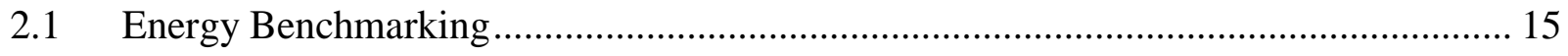

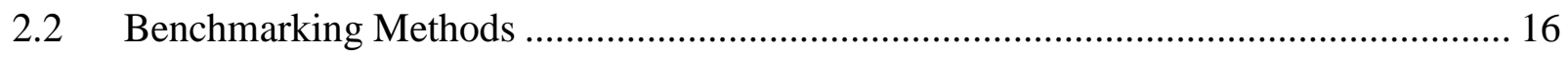

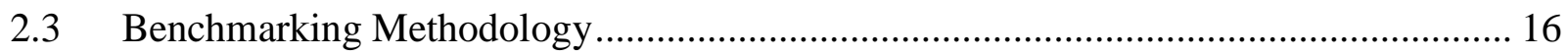

2.4 Gas Fired Oven and Heat Engineering ................................................................... 17

2.5 Industrial Powder - Coating Process ………………................................................ 19

2.6 Cure Dynamics of Powder Coating and Reducing Energy Use................................... 19

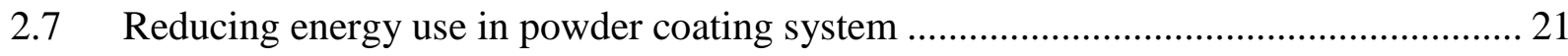

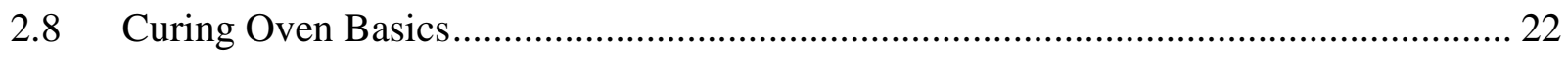

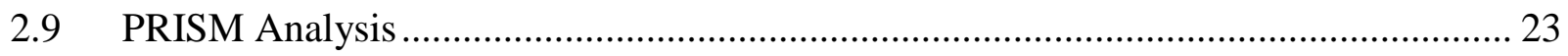

2.10 Simple Ratio-Based Weather Normalization Method.................................................... 25

2.11 Shipping and Receiving Door-Related Energy Consumption........................................ 26

2.12 Square-Foot Area Energy Consumption Method........................................................ 28

2.13 Estimating Non-productive Energy Consumption ........................................................ 28

2.14 Production Scheduling and Shift Optimization for Energy Optimization ..................... 29

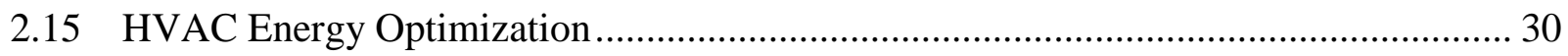

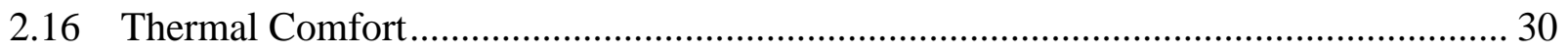

2.17 Ventilation Analysis ............................................................................................. 32 
2.18 Case Study on Energy Management

2.18.1 Advancing Opportunity in Energy Management in Ontario Industrial and

Management Sector

2.18.2 Bottom Line Improvement of Natural Gas Consumption Through Process Ovens:

A Case Study by Enbridge Gas Distribution Inc. in Canada's Greater Toronto Area .......... 35

2.18.3 A Case Study: Improving Energy Performance in Canada ................................ 40

2.18.4 A Case Study: An Energy-Efficiency Program for Swedish Industrial Small and

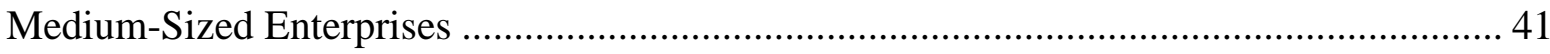

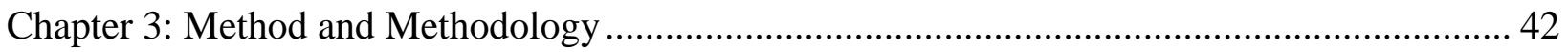

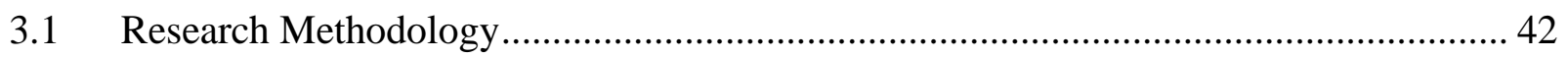

3.2 Process Flow of Powder Coating Company............................................................ 44

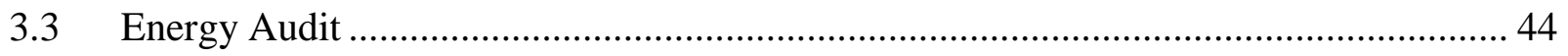

3.4 Primary Data Collection and Site Selection ................................................... 45

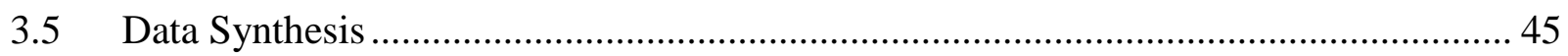

3.6 Process and Seasonal Energy Consumption ................................................... 46

3.7 Estimated Reference Temperature by Regression Analysis and Estimated Normalized

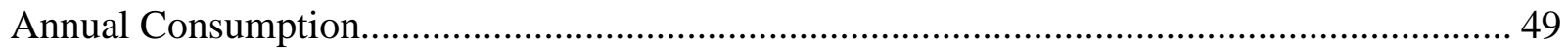

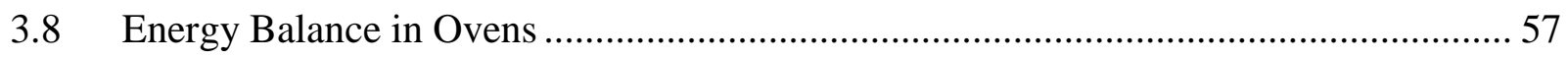

3.9 Mathematical Model and Energy Balance of Oven ........................................... 59

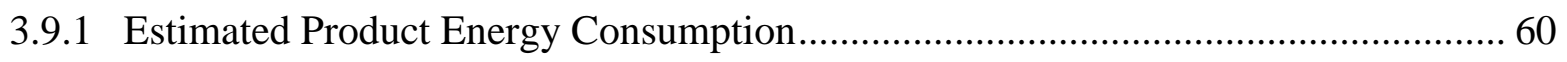

3.9.2 Estimated Energy Produced by Rated Flow Capacity …....................................... 60

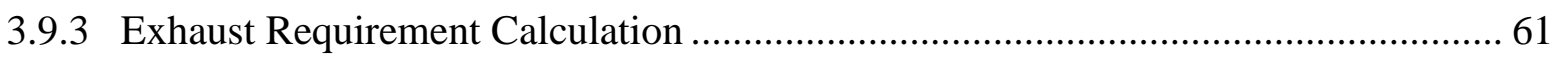

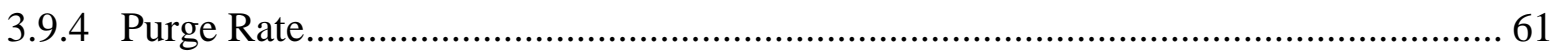




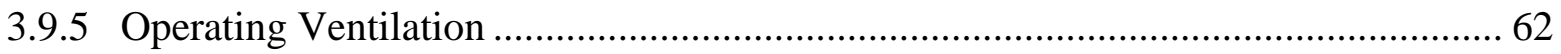

3.9.6 Exhaust Volume at Constant Volume Flow Rate ...................................................... 62

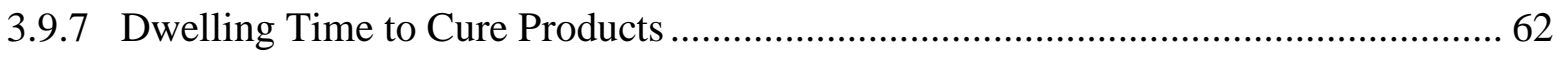

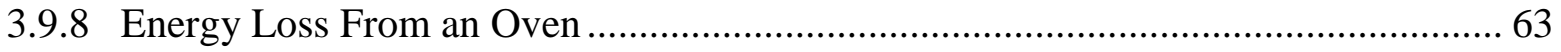

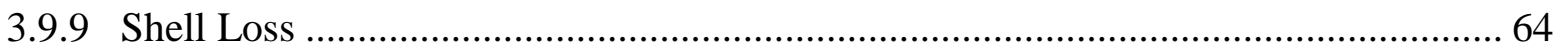

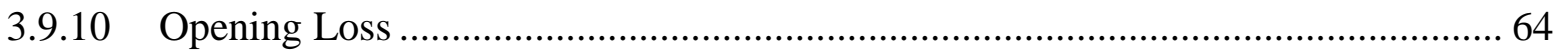

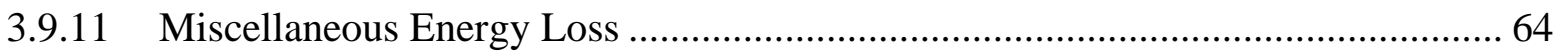

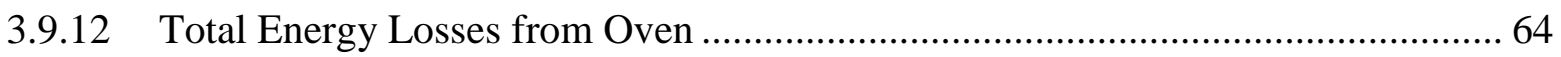

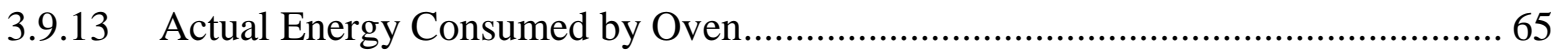

3.10 Productive vs. Non-productive Hours Energy Consumption .......................................... 65

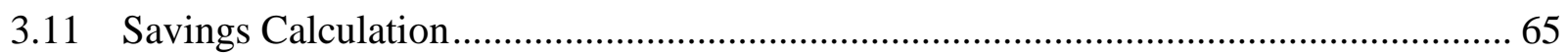

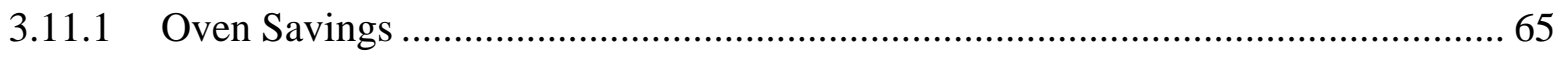

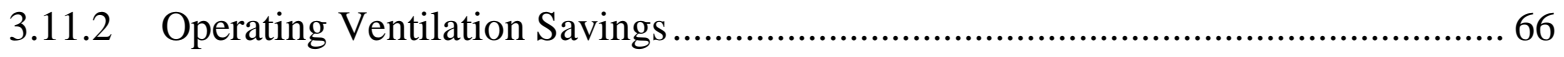

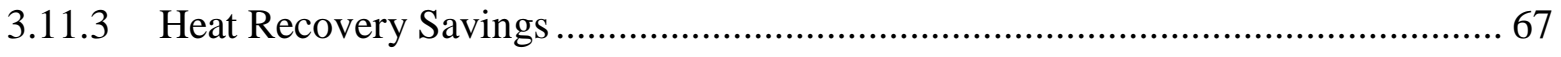

3.11.4 Productive vs. Non-productive Hours Savings Calculation ................................... 67

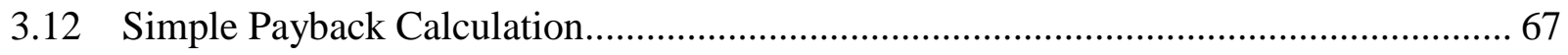

Chapter 4: Analysis of SMEs Energy Consumption and Potential Savings Opportunities .......... 69

4.1 Energy Consumption by Ovens and Percentage of Total Process Consumption........... 69

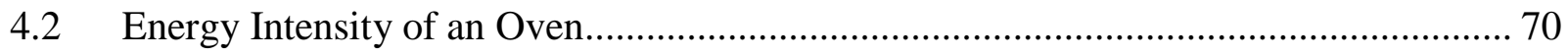

4.3 Energy Intensity Analysis with Different Oven Parameters ........................................ 73

4.4 Energy Consumption Analysis with oven Volume, Area and Operation Hours............ 79

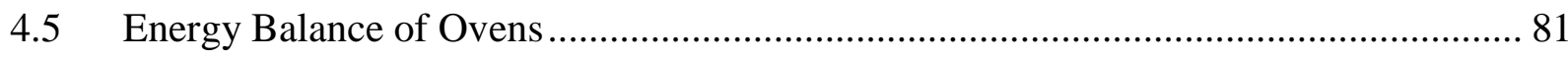

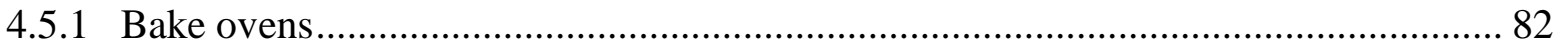




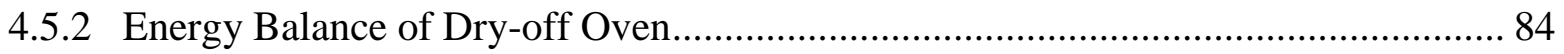

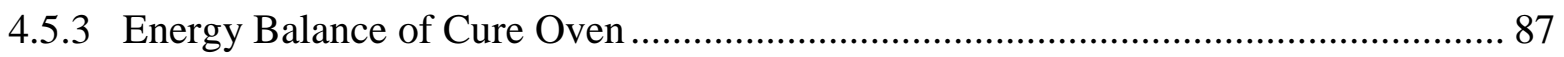

4.6 Exhaust Loss Analysis with Different Parameters ......................................................... 90

4.7 Shell Energy Loss Analysis with Different Parameters ................................................... 94

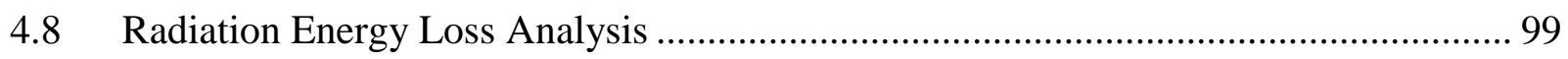

4.9 Productive and Non-productive Hours Natural Gas Consumption Analysis ............... 100

4.10 Non-Productive Hours Energy Consumption Analysis ............................................... 105

4.11 Non-Productive Hours Energy Consumption Analysis Based on Summer Months.... 107

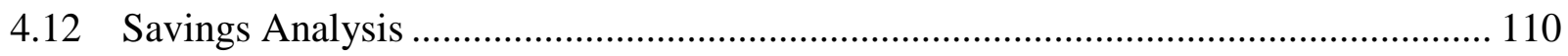

4.12.1 Energy Savings from Oven Exhaust .............................................................. 110

4.12.2 Energy Savings Opportunity from Oven Shell Energy Loss Through Improving

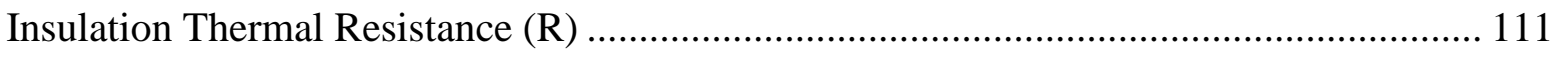

4.12.3 Exhaust Savings and Estimated Cost Savings Through Retrofits (Installation of VFD) 113

4.12.4 Cost Savings Analysis from Shell Energy Loss ................................................ 115

4.13 Maximum Potential Natural Gas Savings Analysis .................................................... 118

4.14 Natural Gas Savings Analysis with Hours of Operations …………………….......... 119

Chapter 5: Result and Discussion of SMEs' Energy Consumption............................................ 121

5.1 Savings from installing Variable Frequency Drive (VFD) ......................................... 122

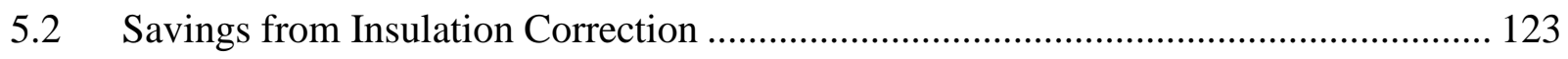

Chapter 6: Conclusion and Recommendations ....................................................................... 124

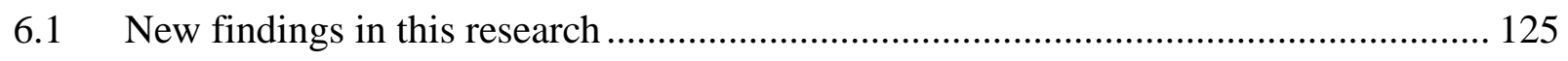

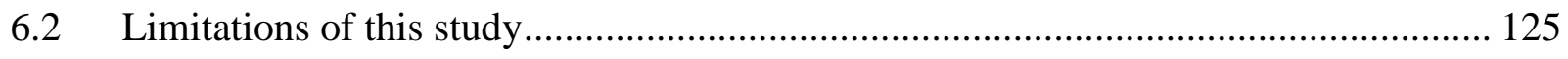


Possible Future Work ................................................................................... 126

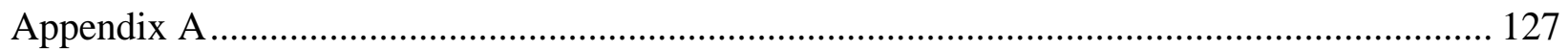

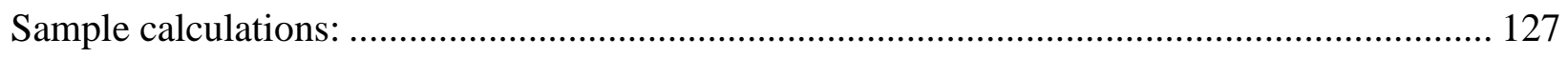

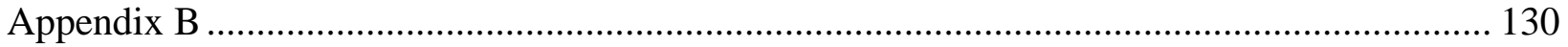

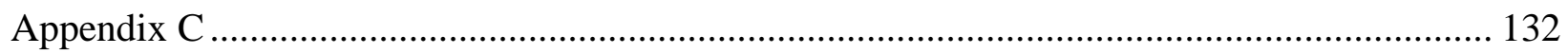

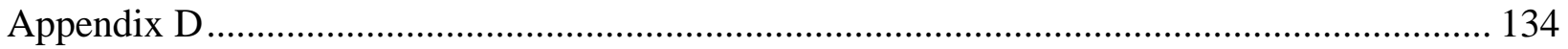

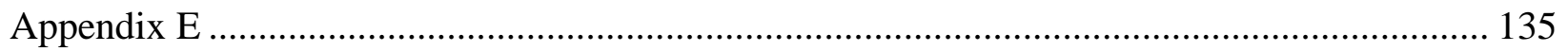

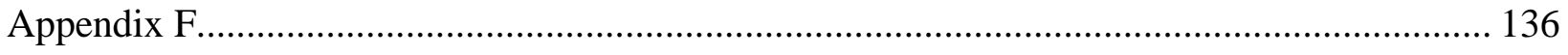

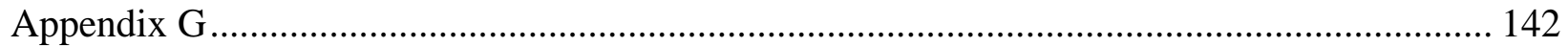

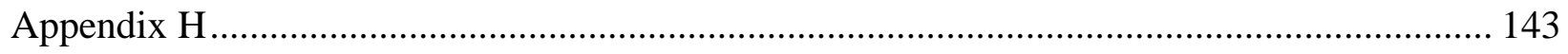

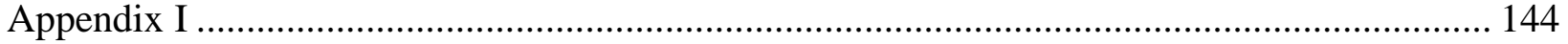

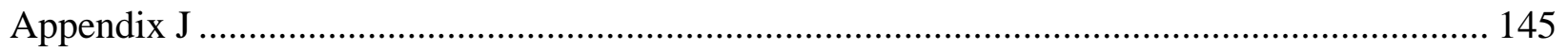

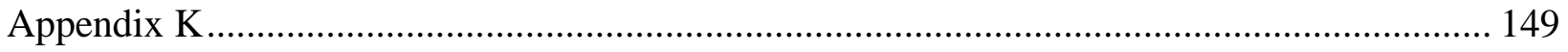

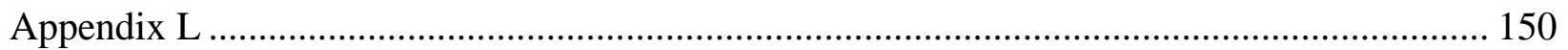

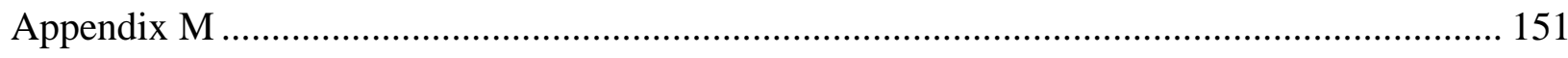

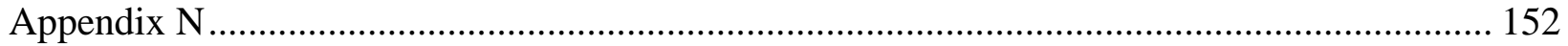

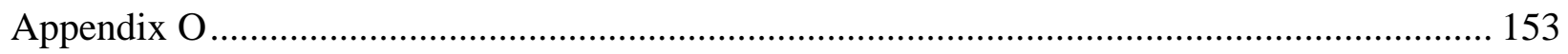

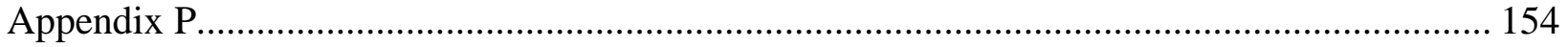

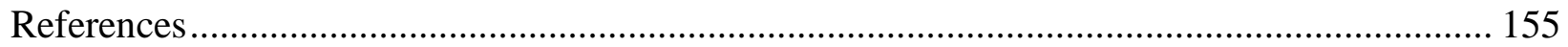




\section{List of Tables}

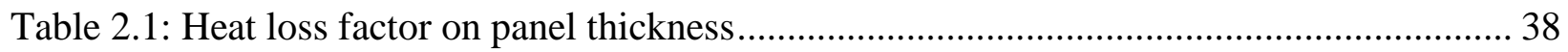

Table 3.1: Sample $\mathrm{R}^{2}$ values based on different reference temperatures in linear regression

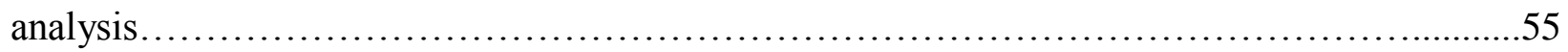

Table 4.1: Summary of energy balance of audited companies.............................70

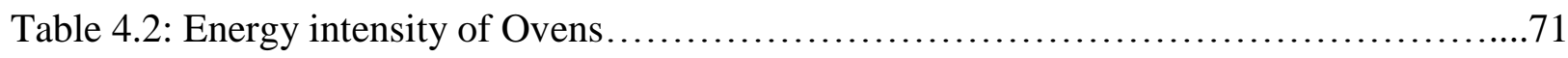

Table 4.3: Oven ranking based on energy intensity by oven volume .......................72

Table 4.4: Oven consumption and oven area/oven volumn multiply hours of operation .........79

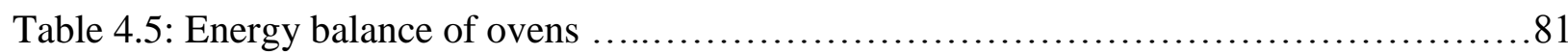

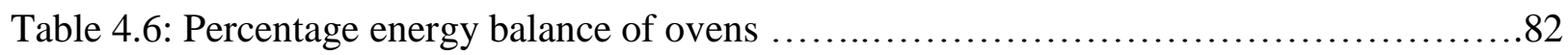

Table 4.7: Exhaust energy loss and temperature difference..............................91

Table 4.8: Oven shell loss per unit area of envelope and per unit volume of ovens .............94

Table 4.9: Oven shell loss and temperature difference ..................................96

Table 4.10: Oven shell loss and oven area ........................................... 98

Table 4.11: Radiation energy loss from oven ..................................... 100

Table 4.12: Summary of natural gas consumption of productive and non-productive hours.....101

Table 4.13: Productive time's consumption as a percentage of total annual consumption.......104

Table 4.14: Percentage non-productive hours and non-productive consumption...............106

Table 4.15: Productive and non-productive hours consumption analysis (summer months).....108

Table 4.16: Exhaust requirements and current exhaust of ovens ...........................111

Table 4.17: Shell energy loss of ovens with different loss factors.......................112

Table 4.18: Exhaust savings from different percentage of exhaust reduction ..................114

Table 4.19: Percentage savings and payback period................................... 115 
Table 4.20: Cost of energy savings with reduced oven envelope loss factors .................116

Table 4.21: Payback analysis based on different oven envelope loss factors.......................117

Table 4.22: Maximum potential savings of total natural gas consumption.........................119

Table 4.23: Natural gas savings per hour of operation.................................. 120 


\section{List of Figures}

Figure 1.1: Canada's secondary consumption by sector, 2009 .............................5

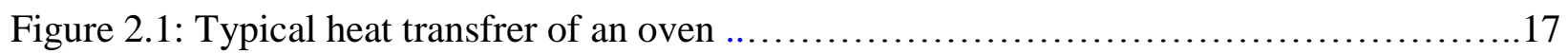

Figure 3.1: Flow diagram of research program to investigate energy-saving opportunities of

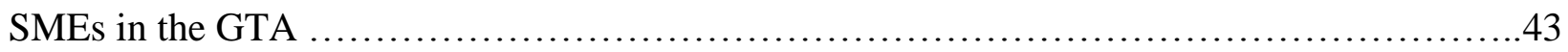

Figure 3.2: Process flow digram of powder coating company (AAWIL)....................44

Figure 3.3: Separation of process and seasonal energy consumption ......................47

Figure 3.4: Typical industrial layout with HVAC network, process flow, and ovens............47

Figure 3.5: Sankey diagram of total energy balance of an industrial plant ..........................48

Figure 3.6: Regresion analysis of outside average temperature and normalized energy

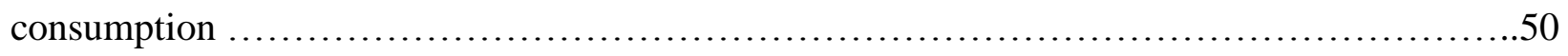

Figure 3.7: Sample analysis by PRISM and NAC value...............................52

Figure 3.8: Sample linear regression analysis in Excel and $\mathrm{R}^{2}$ value.......................54

Figure 3.9: Reference temperatures $\left({ }^{\circ} \mathrm{F}\right)$ with corresponding $\mathrm{R}^{2}$ value in Excel.................55

Figure 3.10: Separation of normalized process and normalized seasonal energy consumption...56

Figure 3.11: Time-temperature relation of curing .................................... 57

Figure 3.12: Process flow of a continuous flow gas fired finishing company.................58

Figure 3.13: Simple process flow and energy balance of ovens .........................................59

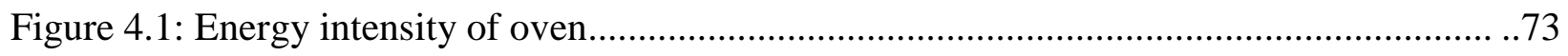

Figure 4.2: Energy intensity in terms of volume vs. oven volume ......................................74

Figure 4.3: Energy intensity in terms of volume vs. oven envelope area................................75

Figure 4.4: Energy intensity in terms of area vs. oven volume .........................................76

Figure 4.5: Energy intensity in terms of area vs. oven operating hours ................................76 
Figure 4.6: Energy intensity in terms of volume vs. temperature difference .77

Figure 4.7: Energy intensity in termd of area vs. temperature difference ...............................78

Figure 4.8: Oven consumption with operating hour $\mathrm{x}$ oven envelope area............................80

Figure 4.9: Oven consumption with operating hour $\mathrm{x}$ oven volume.....................................8

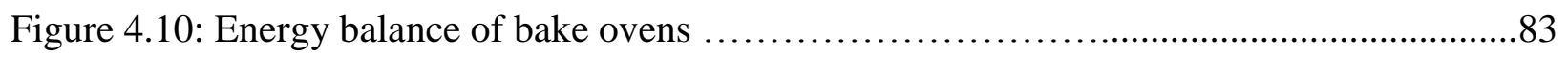

Figure 4.11: Percentage energy balance of bake ovens ............................................ 84

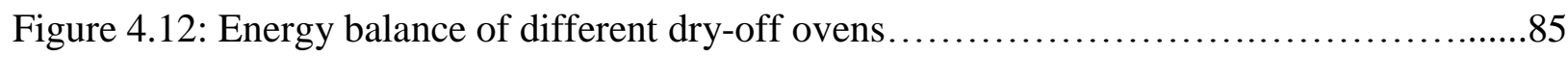

Figure 4.13: Percent energy loss due to exhaust from different dry-off ovens....................86

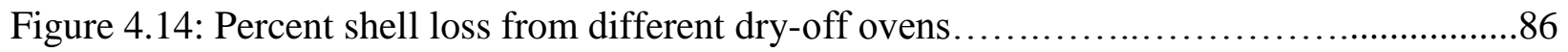

Figure 4.15: Percent product energy consumption from different dry-off ovens................87

Figure 4.16: Energy balance of different cure oven..................................... 88

Figure 4.17: Percent exhaust energy loss from different cure ovens $\ldots \ldots \ldots \ldots \ldots \ldots \ldots \ldots \ldots . . . . . \ldots 8$

Figure 4.18: Percent shell loss from different cure ovens $\ldots \ldots \ldots \ldots \ldots \ldots \ldots \ldots \ldots \ldots \ldots \ldots \ldots . . .89$

Figure 4.19: Percent product energy consumption from different cure ovens ..................90

Figure 4.20: Exhaust energy loss vs. temperature difference $\ldots \ldots \ldots \ldots \ldots \ldots \ldots \ldots \ldots \ldots \ldots . . . \ldots 2$

Figure 4.21: Exhaust energy loss vs. oven envelope area..............................92

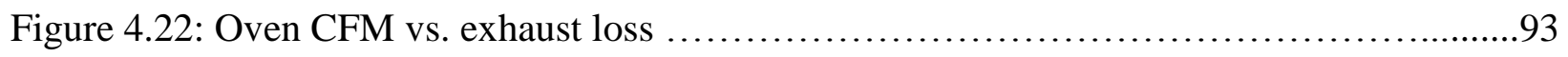

Figure 4.23: Energy loss per unit area of ovens..........................................

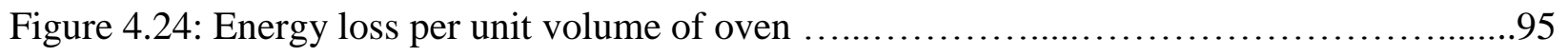

Figure 4.25: Shell loss vs. temperature difference...................................97

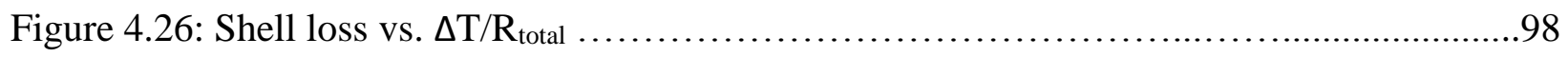

Figure 4.27: Shell loss vs. oven envelope area $\ldots \ldots \ldots \ldots \ldots \ldots \ldots \ldots \ldots \ldots \ldots \ldots \ldots \ldots \ldots \ldots \ldots$

Figure 4.28: Natural gas consumption per hour of production of audited companies ...........102 
Figure 4.29: Productive hours energy consumption index 103

Figure 4.30: Productive index of process energy of the audited plants 103

Figure 4.31: Percent natural gas consumption of productive hours ........................ 105

Figure 4.32: Energy consumption during non-productive hours ........................ 107

Figure 4.33: Energy consumption during non-productive hours (Summer months average)......109

Figure 4.34: Payback period of investment savings based on different insulation loss factors...118

Figure 4.35: Natural gas savings per hour of operation .120 


\section{Abbreviations}

$\mathrm{A} / \mathrm{C}$

ASHRAE

$\mathrm{ACH}$

ACFM

ANSI

CaGBC

CDD

CF

CRA

$\mathrm{CO}$

DHW

DSM

FEA

GDP

GHG

GTA

$\mathrm{HC}$

HDD

$\mathrm{HDD}_{\mathrm{a}}$

$\mathrm{HDD}_{\mathrm{L}}$

$\mathrm{HO}$
Air Conditioner

American Society of Heating, Refrigerating and Air Conditioning Engineers

Air Change Per Hour

Actual Cubic Feet Per Munity

American National Standard Institute

Canada Green Building Council

Cooling Degree Days

Correction Factor

Canada Revenue Agency

Cooling Only

Domestic Hot Water

Demand Side Management

Federal Energy Efficiency Act

Gross Domestic Product

Green House Gas Emission

Greater Toronto Area

Heating and Cooling

Heating Degree Days

Actual HDD of the Billing Period

Long-term Annual HDD

Heating Only 


\begin{tabular}{|c|c|}
\hline HVAC & Heating, Ventilation, and Air Conditioning \\
\hline IESNA & Illuminating Engineering Society of North America \\
\hline IEA & International Energy Agency \\
\hline IEQ & Indoor Environment Quality \\
\hline IESNA & Illuminating Engineering Society of North America \\
\hline ISO & International Organization for Standardization \\
\hline LEED & US Green Building Council's Leadership in Energy and Environmental \\
\hline & Design \\
\hline MBP & Management Best Practice \\
\hline MEPS & Maximum Energy Performance Standard \\
\hline NAC & Normalized Annual Energy Consumption \\
\hline NRCan & National Resources Canada \\
\hline NAICAS & North American Industry Classification \\
\hline NBC & National Building Code \\
\hline NECB & National Energy Code of Canada for Buildings \\
\hline NEPA & National Fire Protection Association \\
\hline NPV & Net Present Value \\
\hline OEE & Office of Energy Efficiency \\
\hline PRISM & Princeton Scorekeeping Method \\
\hline PDCA & Plan, Do, Check, Act \\
\hline RU & Ryerson University \\
\hline SCFM & Standard Cubic Feet Per Minute \\
\hline SWRN & Simple Ratio-Based Weather Normalization \\
\hline
\end{tabular}


TAU

TBP

TSSA

USGBC

VFD

VAV
Heating and Cooling Reference Temperature

Technical Best Practice

Technical Standard and Safety Authority

U.S. Green Building Council

Variable Frequency Drive

Variable Air Volume 


\section{Nomenclature}

h Heat transfer co-efficient $\left[\mathrm{Btu} / \mathrm{hr} \mathrm{ft}^{2} \mathrm{~F}\right]$

$\mathrm{R} \quad$ Over all thermal resistance $\left[{ }^{\circ} \mathrm{F} \mathrm{ft}^{2} \mathrm{hr} / \mathrm{Btu}\right]$

$\mathrm{q}_{\mathrm{c}} \quad$ Rate of heat transfer by convection $\left[\mathrm{Btu} / \mathrm{ft}^{2}{ }^{\circ} \mathrm{F}\right]$

A Surface area to the direction of fluid flow $\left[\mathrm{ft}^{2}\right]$

$\Delta \mathrm{T} \quad$ Temperature difference $\left[{ }^{\circ} \mathrm{F}\right]$

qcd $\quad$ Rate of heat flow through conduction $\left[{ }^{\circ} \mathrm{F} \mathrm{hr} / \mathrm{Btu}\right]$

$\mathrm{k} \quad$ Thermal conductivity $\left[\mathrm{Btu} / \mathrm{hr} \mathrm{ft}^{\circ} \mathrm{F}\right]$

$\mathrm{T}_{\mathrm{s}} \quad$ Surface temperature in Rankin $\left[{ }^{\circ} \mathrm{R}\right]$ scale

$\mathrm{T}_{\infty} \quad$ Ambient temperature on Rankin $\left[{ }^{\circ} \mathrm{R}\right]$ scale

$t_{\mathrm{DT}} \quad$ Overall duel time, is the time parts remain inside oven [min]

tBUT Oven bring up time [min]

$\mathrm{t}_{1} \quad$ New cure time after temperature change [min]

E Normalized annual energy consumption [ $\left.\mathrm{m}^{3} / \mathrm{year}\right]$

$\mathrm{E}_{\mathrm{a}} \quad$ Actual energy consumption $\left[\mathrm{m}^{3} /\right.$ year $]$

$\mathrm{HDD}_{\mathrm{a}} \quad$ Actual HDD of the billing period $\left[{ }^{\circ} \mathrm{F}\right.$ day $]$

$\mathrm{HDD}_{\mathrm{L}} \quad$ Long-term annual HDD [ ${ }^{\circ} \mathrm{F}$ day $]$

T base $\quad$ Base temp $\left[{ }^{\circ} \mathrm{F}\right]$

$\mathrm{T}_{\text {mean }} \quad$ Mean outside air temperature $\left[{ }^{\circ} \mathrm{F}\right]$

k Constant [0.7]

Q Air flow rate [CFM]

$\mathrm{C}_{\mathrm{A}} \quad$ Air flow co-efficient $\left[\mathrm{CFM}\left(\mathrm{ft}^{2}\right.\right.$-in. water $\left.) 0.5\right]$ 


\begin{tabular}{|c|c|}
\hline $\mathrm{R}_{\mathrm{P}}$ & Is a pressure factor (in. of water 0.5 ) \\
\hline M & Rate of metabolic heat production $\left[\mathrm{W} / \mathrm{m}^{2}\right]$ \\
\hline W & Rate of mechanical work accomplished $\left[\mathrm{W} / \mathrm{m}^{2}\right]$ \\
\hline $\mathrm{q}_{\mathrm{sk}}$ & Rate of heat loss from skin $\left[\mathrm{W} / \mathrm{m}^{2}\right]$ \\
\hline $\mathrm{q}_{\text {res }}$ & Rate of heat loss through respiration $\left[\mathrm{W} / \mathrm{m}^{2}\right]$ \\
\hline $\mathrm{E}_{\mathrm{NG} \text { input }}$ & Energy input of natural gas through burner $[\mathrm{Btu} / \mathrm{hr}]$ \\
\hline$E_{P}$ & Energy consumption by product [Btu/hr] \\
\hline$E_{c}$ & Energy consumption by conveyor $[\mathrm{Btu} / \mathrm{hr}]$ \\
\hline $\mathrm{E}_{\mathrm{Exh}}$ & Exhaust energy loss [Btu/hr] \\
\hline $\mathrm{E}_{\text {Shell }}$ & Energy loss through shell [Btu/hr] \\
\hline$E_{\text {open }}$ & Energy loss through oven opening [Btu/hr] \\
\hline $\mathrm{m}_{\mathrm{f} \text { produc }}$ & Mass of product $[\mathrm{lb} / \mathrm{hr}]$ \\
\hline$C_{p}$ & Material specific heat capacity $\left[\mathrm{Btu} / \mathrm{lb}{ }^{\circ} \mathrm{F}\right]$ \\
\hline $\mathrm{E}_{\mathrm{MH}}$ & Energy required by the material handling equipment $[\mathrm{Btu} / \mathrm{hr}]$ \\
\hline $\mathrm{m}_{\mathrm{MH}}$ & Mass of material handling equipment $[\mathrm{lb} / \mathrm{hr}]$ \\
\hline$Q_{\text {open }}$ & Flow rate of dry flue gas from the oven opening in CFM \\
\hline $\mathrm{U}$ & Overall heat transfer co-efficient of oven shell material $\left[\mathrm{Btu} / \mathrm{ft}^{2}{ }^{\circ} \mathrm{F}\right]$ \\
\hline $\mathrm{Q}_{\text {Exhaust }}$ & Flow rate of dry flue gas from exhaust from oven in CFM \\
\hline$t_{\text {purge }}$ & Purge time in minute \\
\hline$V_{\text {oven }}$ & Volume of oven $\left[\mathrm{ft}^{3}\right]$ \\
\hline $\mathrm{VF}_{\text {exh }}$ & Exhaust volume [SCFM] \\
\hline $\mathrm{CF}$ & Conversion factor \\
\hline
\end{tabular}


$\mathrm{T}_{\text {oven }} \quad$ Running temperature of oven $\left[{ }^{\circ} \mathrm{F}\right]$

$\mathrm{T}_{\text {ref }} \quad$ Facility reference temperature $\left[{ }^{\circ} \mathrm{F}\right]$

NAC Normalized annual consumption [ $\left.\mathrm{m}^{3} / \mathrm{year}\right]$

M Heating or cooling slope obtained in the regression line in the scatter plot

$\mathrm{X} \quad \mathrm{HDD}$ corresponds to optimal reference temperature $\left[{ }^{\circ} \mathrm{F}\right.$ day]

C Is the fixed value on the regression line on the scatter plot $\left[\mathrm{m}^{3}\right]$

$\mathrm{m}_{\mathrm{fp}} \quad$ Production throughput $[\mathrm{lb} / \mathrm{hr}]$

$V_{\text {line }} \quad$ Velocity of conveyor [ft/min]

PBP Payback period [year]

$A_{t} \quad$ Sum of annual return $[C A D]$

$\mathrm{C}_{\mathrm{o}} \quad$ Capital investment [CAD] 


\section{Greek Letters}

$\sigma \quad$ Stefan Boltzmann constant $\left[1.714 \times 10^{-9} \mathrm{Btu} / \mathrm{hr} \mathrm{ft}^{2} \mathrm{R}^{4}\right]$

$\varepsilon \quad$ Emissivity (assumed value of one as ideal emitter)

$\alpha \quad$ Base-level consumption [HO, $\mathrm{CO}, \mathrm{HC}]\left[\mathrm{m}^{3} /\right.$ year $]$

$\beta_{\mathrm{h}} \quad$ Heating slope $[\mathrm{HO}, \mathrm{HC}]\left[\mathrm{m}^{3} /{ }^{\circ} \mathrm{F}\right.$ year $]$

$\beta_{\mathrm{c}} \quad$ Cooling slope $[\mathrm{CO}, \mathrm{HC}]\left[\mathrm{m}^{3} /{ }^{\circ} \mathrm{F}\right.$ year $]$

$\delta_{\mathrm{h}} \quad 1$ for heating only (HO) and combined heating and cooling (HC) model, otherwise zero

$\delta_{\mathrm{c}} \quad 1$ for cooling only $(\mathrm{CO})$ and combined heating and cooling (HC) model, otherwise zero

$\tau_{\mathrm{h}} \quad$ Heating reference temperature $[\mathrm{HO}, \mathrm{HC}]\left[{ }^{\circ} \mathrm{F}\right]$

$\tau_{\mathrm{c}} \quad$ Cooling reference temperature $[\mathrm{CO}, \mathrm{HC}]\left[{ }^{\circ} \mathrm{F}\right]$

$\mathrm{H}_{0}\left(\tau_{\mathrm{h}}\right)$ Long term average heating degree day per year to the PRISM to estimate reference temperature

$\mathrm{C}_{0}\left(\tau_{\mathrm{c}}\right)$ Long term average cooling degree day per year to the PRISM to estimate reference temperature 


\section{Chapter 1: Introduction}

\subsection{Introduction}

Business is a dynamic and complex process with challenges such as globalization and climate change. Business changes rapidly and frequently. The manufacturing sector faces new competition every day; to survive in the market, manufacturing companies must manage challenges such as manufacturing technology, product features, production partners, and working style. These are the major research fields of manufacturing companies aside from energy consumption optimization. In addition to competition, studies continue to investigate managing energy resources and reducing harmful environmental effects such as greenhouse gas (GHG) emissions and global warming. Large-scale manufacturing industries are capable of keeping pace with this changing environment, but small and medium-scale manufacturers lag behind. Small and medium-scale enterprises (SMEs) provide support to large-scale businesses; few operate independently. SMEs have limited capability and skilled workers to implement new and competitive trends. As a result, they are struggling to survive these obstacles. Therefore, the sustainable development of SMEs is not encouraging as energy management and savings measures reduce production costs, which results in reduced operating costs, advantages heretofore available mainly to large companies that maintain internal energy management departments [1].

\subsubsection{Background}

Industrial energy use has been growing in recent decades. The growth rate varies between large and small industries. The fastest growth in industrial energy demand has been in emerging 
economies, although efficiency has improved substantially in all the energy-intensive manufacturing industries over the last 25 years in every region [1]. Basic industrial processes and products are similar across the globe, which enables the use of universal indicators such as break-even analysis, profitability ratio analysis, and other tools. However, the greatest challenge in establishing precise indicators lies in detailed analysis. In order to make a proper comparison between similar types of companies, their system boundaries should be identical. Reliable indicators can be obtained from a good data set from detailed analysis collected through energy audits of the companies. Good data sets are more accurate in best-practice companies. A report by the International Energy Agency (IEA) showed that small-scale manufacturing plants using outdated processes, low-quality fuel and feedstock, and weak transportation infrastructure contribute to industrial inefficiency [2]. This report shows that the profitability opportunity is there for industries in which energy is not the main operating cost. However, energy-intensive SMEs have a potential opportunity to reduce operating costs through energy-saving programs.

\subsubsection{Definition of SMEs}

Industry Canada defines a business as a registered establishment that has at least one paid employee, with payroll deductions remitted to the Canada Revenue Agency. Also, the business must have reported annual sales revenue of $\$ 30,000$ and must have filed for a federal corporate income tax return at least once in the previous three years. For SME research and statistics, Industry Canada uses a definition based on the number of paid employees (excluding indeterminate employees, i.e., contract and self-employed workers). Also excluded from the definition of SMEs from the industrial sector are public administration institutions, including 
schools and hospitals, public utilities, and nonprofit associations. More specifically, Industry Canada defines types of businesses based on paid employees in the following categories [3]:

1. A small business that has 1 to 99 paid employees

2. A medium business that has 100 to 499 paid employees

3. A large business that has 500 or more paid employees

\subsubsection{Category of SMEs}

SMEs are defined as firms with fewer than 500 employees. This is an acceptable definition by Statistics Canada, Industry Canada, the Small Business Association of Canada, the World Bank, and the Organization for Economic Co-operation and Development. They are subdivided into three major categories [3]:

1. Micro-sized enterprise, which has fewer than 5 employees

2. Small-sized enterprise, which has at least 5 but fewer than 100 employees

3. Medium-sized enterprise, which has at least 100 but fewer than 500 employees There are other types of classifications based on revenue or shipments. Industries or businesses with revenue under $\$ 25$ million or a volume of manufacturing shipments less than $\$ 25$ million can be categorized as an SME firm. This categorization is not widely used because the value of revenue and shipments is affected by inflation. All industries are classified as per their processes or economic activities in North America through the North American Industry Classification System (NAICS). The goods-processing sector is limited to the following NAICS codes [4]:

- 11 - Forestry

- 21 - Mining

- 22 - Utilities 
- 23 - Construction

- 31-33 - Manufacturing

The manufacturing sector (NAICS 31-33) is the major concern of this research work.

\subsubsection{Current Situation of SMEs}

The sustainable growth rates of Canada's small, medium, and large businesses are 82\%, 63\%, and $60 \%$, respectively, over the period $2000-2010$ [1]. The sustainable growth rate defines the maximum growth a company can sustain without additional investment [5]. SMEs are categorized in different sectors based on businesses that are mainly goods (primary, construction, and manufacturing), services (wholesale trade, retail trade, professional, scientific, and technical), and producing sectors. Of all subsectors, the primary and manufacturing sectors had growth rates of $2 \%$ and $3 \%$, respectively. The growth rates in the service sectors were $5 \%$ to $7 \%$ [1]. The overall correlation coefficient between actual growth and sustainable growth was -0.16 in that period. These findings raise the question of capabilities and limitations of SMEs in Canada [1]. At the same time, energy consumption is escalating, although energy remain limited.

In Canada, the manufacturing sector accounted for largest share $(67.8 \%)$ of energy consumption within the industrial sector (37\%) [5]. In 2011, energy consumption in the manufacturing sector grew $1.8 \%$ over 2010 , where the output grew $2.9 \%$ in the same period of time [5]. Overall consumption rose from $28 \%$ to $29.8 \%$. Overall energy consumption in different sectors is presented in Figure 1.1 [5]. 


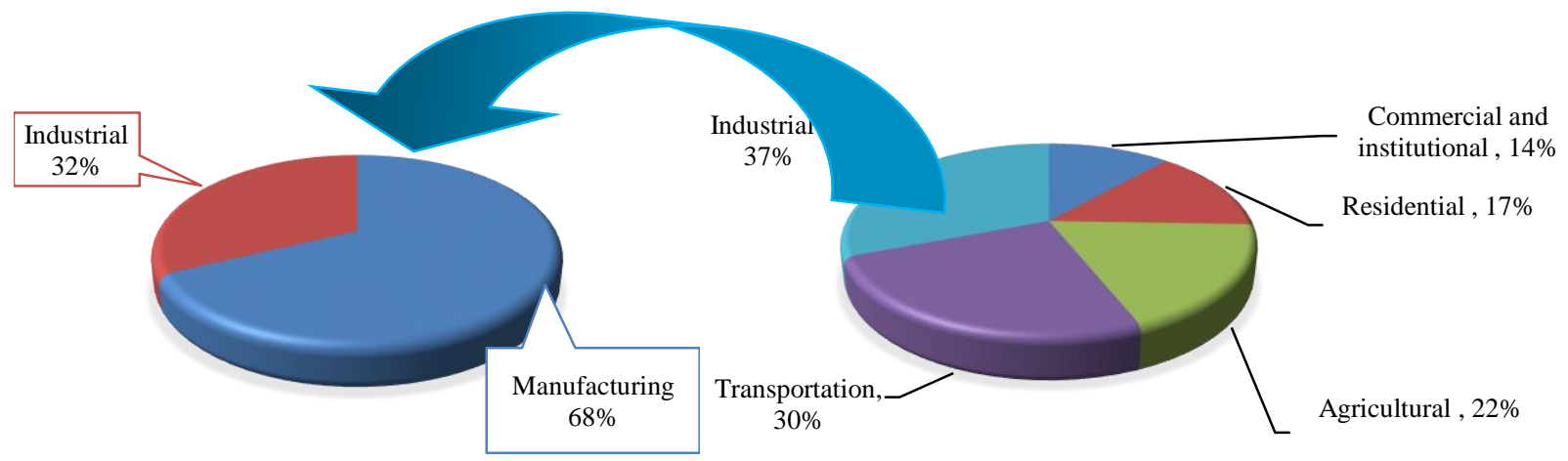

Source: National Resource Canada 2012

Figure 1.1: Canada's secondary consumption by sector, 2009 [5]

Approximately 3.5 billion tons of crude oil are consumed in a year; within this consumption data, the transportation sector consumed the most, followed by the industrial sector [3]. It is commonly recognized by business owners that efficient energy use can reduce operating costs and harmful environmental effects [4].

The SME sector is a significant part of the Canadian economy, with almost 250,000 establishments in 2003 [4]. These SMEs are consuming significant amounts of energy. However, energy consumption data specific to this sector is sparse. This shortage of energy consumption data is a drawback to energy-management programs, keeping them from addressing the specific needs of SMEs.

\subsubsection{Benefits of SME Energy Management and Savings Programs}

The Canadian Industrial Energy End-Use Data Analysis Center studied SME energy-saving opportunities in 2003 for 11,000 SME industries. It found cost-saving opportunities of 35\% in the categories of lighting, air compressors, and motors [4]. 
The Canadian manufacturing sector had an energy-saving opportunity of \$1.532 billion in 2003 . Individual establishments accounted for energy-saving opportunities of an average of $\$ 24,000$ annually [4,5]. This was the result in 2003 (without any previous research ever being done on this aspect of SMEs). Beginning then, Natural Resources Canada (NRCan) started working to provide more potential data sets for energy consumption analysis. NRCan identified that the manufacturing sector consumed the most energy and held the highest potential for energy savings. Therefore, energy-saving programs in SMEs will help reduce operating costs and further investigate sustainable improvements.

\subsubsection{Barriers to Implementing Energy-Saving Programs}

Energy audits are the preliminary stage of energy-saving programs. However, there are barriers that SME companies face, including economics, technology, and resources. These barriers restrict the actual realization of energy-saving potential. In recent decades, there has been apparent improvement because of continuous research on energy-saving opportunities. Although

there is gradual progress, there are also factors that limit actual improvement $[6,7,8]$ :

- Conflict of priority between energy conservation and capacity expansion

- Shortage of funds for energy-conservation projects

- Shortage of human capital and lack of information on technological options

- Lack of production management and inefficient products 


\subsubsection{Energy Audits}

Energy audits are the process of verifying, monitoring, and analyzing energy uses in a facility. An energy audit is the first step to understanding how energy is being used in a firm [10]. Costbenefit analysis and steps to reduce energy consumption are major parts of energy audits [11].

There are two major types of energy audits: macro and micro. Both macro and micro audits depend on the scope of work and requirements by potential customers. A macro audit starts at relatively higher levels and involves a broad physical scope and less detail. A micro audit has a narrow scope that often begins where a macro audit ends. In-depth analysis is conducted in micro audits. Individual equipment energy-efficiency analysis is a major part of micro-energy audits. Generally, micro-level analysis requires expertise in the field of engineering and technology. Therefore, energy-consumption analysis and identification of specific energy-saving measures are the main focus of energy audits [12]. These have different levels and depths, which are listed below [13]:

1. Level I analysis: walkthrough analysis which is inspection of the facility to identify maintenance, operation, or deficient equipment issue and to also identify area which need further appraisal.

2. Level II analysis: where performing cost-effective calculations and may include performing, monitoring, metering, testing to identify actual energy consumption and losses. ASHRAE-level-II energy survey and analysis includes in this type.

3. Level III analysis: where performance of detail analysis through computer modeling to determine the actual yearly energy consumption. ASHRAE-level-III energy survey and analysis includes in this type. 
The type of audit depends on the funding, cost and potential of the energy conservation opportunity, accuracy of the information, type of facility, and processes within a facility.

\subsubsection{Goals of the Energy Audit}

The goals of an energy audit are:

1. Determine the type and cost of energy use.

2. Identify how energy is being used and where it is wasted.

3. Identify and analyze more cost-effective ways to use energy.

4. Perform an economic analysis on those cost-effective energy uses alternatives.

\subsubsection{Steps in the On-site Energy Audit}

The step-by-step progression of an energy audit is:

1. Data collection and review

2. Plant survey and system measurements, including layout and operating schedule for facility

3. Equipment inventory

4. Building use pattern to show annual needs for heating, cooling, and lighting

5. Observation and review of operating practices

6. Data analysis

This information is necessary to determine where, when, why, and how energy is being used. 


\subsubsection{Equipment List for Energy Audit}

Before conducting an energy audit, some information and review of equipment in the facility are important:

1. Identify all large pieces of energy-consuming equipment such as heaters, Heating, Ventilation, and Air Conditioning (HVAC), and specific process-related equipment.

2. List all major energy-consuming equipment, their annual hours of use, and energy ratings or efficiency.

\subsubsection{Major Systems to Consider for Energy Audit}

Major equipment depends on function and type of the facility. However, there is common major equipment to consider during an energy audit:

1. Building envelope

2. HVAC system

3. Electrical supply system

4. Lighting

5. Boiler and steam system

6. Hot/Cold water system

7. Compressed air system

8. Motors

9. Special purpose process equipment

10. Water and sewer system 


\subsubsection{Difference Between Energy Audit, Energy Conservation, and Energy Efficiency}

An energy audit is a systematic analysis of energy consumption in a facility, which provides an energy use depiction in the field of energy management [14]. The purpose of an energy audit in energy management is to balance total energy input with its use.

Energy conservation is the reduction of energy consumption in a process or by an organization through economy, reduction of waste, and more efficient use. Energy conservation is separate from energy efficiency, but they are related concepts. Energy conservation is achieved when utilizing new technology and improved processes and is measured in physical terms. Therefore, energy conservation can be the result of several improved processes or developments, such as productivity increases or technological progress, for example, opening a window in the summertime instead of turning on an air conditioner.

Energy efficiency is the percentage of total energy input to produce useful output. Energy efficiency is achieved by reducing energy intensity of equipment, processes, or areas of production without affecting output, or comfort levels. One specific example is replacing traditional light bulbs with compact fluorescent lamps. The light level is better, and energy costs are reduced.

The difference between energy conservation and energy efficiency is that energy conservation means less energy use through behavioral change while energy efficiency means reducing energy consumption through effective use of equipment without changing the comfort standard. Energy conservation can sometimes affect comfort level [15]; for example, lowering the thermostat in the winter is energy conservation, but installing an energy-efficient heater and insulation is energy efficiency [15]. 


\subsubsection{Demand-Side Management}

Demand-side management (DSM) is also known as demand management. The purpose of DSM is to reduce consumers' energy demand or shift energy demand to off-peak hours through various methods [16] such as financial incentives and education. The goal is not to reduce overall energy consumption but to shift demand to off-peak hours, such as nights and weekends. When peak demand is increased, the system requires higher production capability and reliability, which incurs more costs. If some peak demand is shifted to off-peak hours, then peak demand can be reduced. The concept of DSM appeared after the energy crises in 1973 and 1979. DSM was introduced by the Electric Power Research Institute in 1980 [16]. The basic concept is to store energy during off-peak hours and deliver it during peak hours to balance the overall demand load. DSM has a major role in high investments in generation, transmission, and distribution networks. DSM also reduces harmful greenhouse gas emissions and provides significant economic and environmental benefits [17]. The objectives of DSM are:

- Reduction of customer energy bills

- Reduction in the need for new natural gas sources

- Stimulation of economic development

- Increase in the competitiveness of local enterprises

- Reduction in air pollution

- Reduced dependency on foreign energy sources 


\subsection{Energy Management Plan and Related Code}

Energy management plans are roadmaps to maximize industrial facilities' productivity while minimizing energy use. Energy management plans reach their goals for reducing energy consumption and achieve cost savings. Components of an energy management program are [18]:

1. Company energy strategy

2. Energy cost and use, tracking, profiling

3. Energy audit of facility

4. Analysis of operation and maintenance

5. Energy economics analysis

6. Implementing energy projects

7. Monitoring energy conservation measures

8. Company training

An energy management plan has to maintain several codes and standards for safety and comfort. There is no difference between codes and standards. A code is broad in scope and covers a wide range of issues while a standard is narrow in scope and covers a limited range of issues. Both are enforceable through legislation [18].

1. National Model Construction Code

(a) National Building Code of Canada (NBC): addresses the design and construction of new buildings and the substantial renovation of existing buildings

(b) National Energy Code of Canada for Buildings (NECB): addresses technical requirements for the construction of energy-efficient buildings

2. ASHRAE/IESNA 90.1-2010: addresses building compliance of HVAC, energy trade off with cost budget method, building envelope, and lighting 
3 ASHRAE/IESNA standard 189.1: addresses high-performance green buildings

4. ANSI/ASHRAE/IESNA 100-2006: addresses potential energy-saving measures for existing buildings

5. Energy Performance Standard (MEPS): addresses the maximum amount of energy that may be consumed by a product

6. Federal Energy Efficiency Act (EEA): addresses regulating energy efficiency for products in some provinces

7. Standard 55-2004: addresses thermal environmental conditions for human occupancy

8. Standard 62.1-2007: addresses ventilation for acceptable air quality

9. Standard 62.2-2007 addresses ventilation and acceptable indoor air quality in low rise residential buildings

10. Indoor Environment Quality (IEQ) level: addresses lighting level, noise, and controllability of indoor environment management systems

11. National Fire Protection Association (NFPA) 86: addresses safe operation standards for ovens and furnaces

\subsection{Thesis Objective}

Potential energy-saving analysis and process energy-consumption analysis are the major methods of this research. This research has made an effort to identify indicators by which industry facilities and processes can be benchmarked. Industries can be categorized by high-potential energy-saving opportunities and low-potential energy-savings opportunities from different subsectors. This research also identifies two indices: 1) an index of oven energy intensity by 
which industrial plants can be benchmarked; 2) productive hours index, which can also be used to benchmark industrial plants.

Major analysis focused on powder-coating and food-processing companies. Approximately 11 companies' data sets from each subsector with actual hourly production output provided realistic energy-consumption trends. A payback analysis was performed with cash flow (e.g., payback with a simple interest rate, benefit-cost ratio, and net present value).

\section{$1.4 \quad$ Structure of Thesis}

The work is organized into five chapters:

Chapter 1: Introduction and background on the research, and outline of the overall objective of the study

Chapter 2: Literature review on small and medium-sized enterprises' current features, energyconsumption trends, and benchmarking

Chapter 3: Energy audit method and methodology for energy consumption, and energy-savings analysis and payback analysis in order to update or modify system operations and/or processes to reduce energy consumption in SMEs

Chapter 4: Analysis of SMEs energy consumption and potential savings opportunities.

Chapter 5: Results and discussion of energy consumption and savings in audited companies, analysis of trends of process energy consumption of SMEs in the Greater Toronto Area (GTA), and discussion of energy indicators in process energy consumption

Chapter 6: Conclusion and recommendations 


\section{Chapter 2: Literature Review}

Published research papers and reports are the basis of this literature review. Actual energy data sets used for this thesis were done through an energy audit of SMEs arranged by Enbridge Gas Distribution Inc. Many case studies on energy audits and benchmarking were reviewed to enhance this research work.

\subsection{Energy Benchmarking}

Benchmarking is the process of determining a baseline of energy consumption to compare with other companies. Companies can see how well they are performing in comparison with others through the benchmarking process and can determine ways in which to become more competitive with other companies [15].

In the past, surveyors used to mark on hard surfaces and place indentations on items to help other craftsmen with a point of reference to continue building. This process was known as benchmarking. Companies use benchmarking as a point of reference in the present business world, but they utilize statistical tools instead of physical benchmarking. Therefore, benchmarking is a process of comparing manufacturing operations to other similar companies. A practical example is a school report card or a standardized test, by which one student is compared to his/her peers. The benchmarking process also provides some indicators, such as revenue, production amount, energy consumption, employee productivity and quality, etc. [15]. 


\subsection{Benchmarking Methods}

Benchmarking is the most effective method of analysing organizational activities, including finance, production, energy consumption and quality, etc. It marks comparative trends of one or more types of activities achieved within the same type of company by in-depth analysis and study. Benchmarking starts one on the way to a deeper understanding of the internal processes. Then, competitors or the same types of organizations are comparatively analyzed. Benchmarking focuses on practices, and its main purpose is to learn from those practices that support the best results. There is a clear trend in developing specific characteristics and the need for benchmarking. It is widely practiced as a structured process of improvement. This generally follows the Deming continuous improvement cycle: plan, do, check, act (PDCA) [17].

\subsection{Benchmarking Methodology}

Energy performance benchmarking/rating methodology is suitable for product energy consumption (unit product). Exhaust emission performance benchmarking is used to analyze exhaust emission levels. Environmental impact analysis is used to identify environmental pollution and climatic change. There are a few ratings, such as ISO 14001 and ISO 1403, and the Global Reporting Initiative provides guidance for benchmarking direct and indirect energy use [17]. A key performance indicator is another type of benchmarking methodology that helps to indicate a company's annual achievement target over goals. 


\subsection{Gas Fired Oven and Heat Engineering}

Heat transfer is a key principle in the process of powder-coating and curing for finishing companies, as well as baking food products in a gas fired oven for food companies. The basic principle is heat transfer, which includes conduction, convection, and radiation. Among these heat transfer principles, convection and conduction play the major role in the process, while radiation contributes much less. Convection is a process by which heat energy is transferred between a solid and fluid flowing past it. The rate of heat transfer through convection is determined by Newton's law [19]:

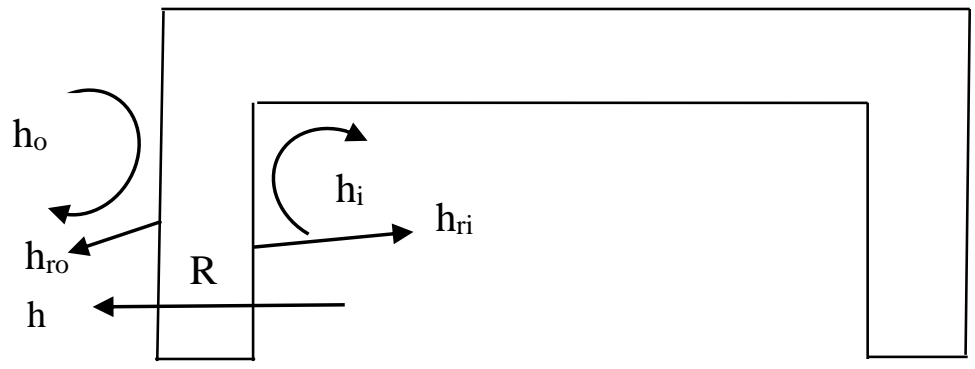

Figure 2.1: Typical heat transfer in an oven

$\mathrm{q}=\mathrm{hA}(\Delta \mathrm{T})[\mathrm{Btu} / \mathrm{hr}]$

Where,

$\mathrm{q}=$ rate of heat transfer by convection $[\mathrm{Btu} / \mathrm{hr}]$

$\mathrm{h}=$ average convective heat transfer co-efficient. The value of convective heat transfer

co-efficient depends on: physical properties of a fluid, geometry of the surface, and temperature difference $\left[\mathrm{Btu} / \mathrm{hr} \mathrm{ft}^{2}{ }^{\circ} \mathrm{F}\right]$.

$\mathrm{A}=$ surface area normal to the direction of fluid flow $\left[\mathrm{ft}^{2}\right]$. 
$\Delta \mathrm{T}=$ Temperature difference between the surface and the fluid $\left[{ }^{\circ} \mathrm{F}\right]$

Conduction heat transfer (wall) in an oven is determined by Fourier's law:

$\mathrm{q}=-\mathrm{k} A \frac{\mathrm{dT}}{d x} \quad[\mathrm{Btu} / \mathrm{hr}]$

Where,

$$
\begin{aligned}
& \mathrm{q}=\text { rate of heat flow in } \mathrm{X} \text { direction (or } \mathrm{Y} / \mathrm{Z} \text { direction) through conduction } \\
& \mathrm{k}=\text { thermal conductivity of material }\left[\mathrm{Btu} / \mathrm{hr} \mathrm{ft}{ }^{\circ} \mathrm{F}\right] \\
& \frac{\mathrm{dT}}{d x}=\text { temperature gradient (positive when heat flows from higher temperature to lower } \\
& \text { temperature and negative when opposite.) }\left[{ }^{\circ} \mathrm{F} / \mathrm{ft}\right]
\end{aligned}
$$

Radiation heat transfer in an oven is determined by Stefan-Boltzmann's law:

$\mathrm{q}=\varepsilon \sigma \mathrm{A}\left(\mathrm{T}_{\mathrm{s}}{ }^{4}-\mathrm{T}_{\infty}{ }^{4}\right)$

Where,

$$
\begin{aligned}
& \mathrm{q}=\text { rate of heat flow by radiation }[\mathrm{Btu} / \mathrm{hr}] \\
& \mathrm{T}_{\mathrm{s}}=\text { surface temperature on Rankin }\left({ }^{\mathrm{o}} \mathrm{R}\right) \text { scale }\left[{ }^{\circ} \mathrm{R}={ }^{\circ} \mathrm{F}+459.67\right] \\
& \mathrm{T}_{\infty}=\text { ambient temperature on Rankin }\left({ }^{\circ} \mathrm{R}\right) \text { scale } \\
& \mathrm{A}=\text { surface area of radiation }\left[\mathrm{ft}^{2}\right] \\
& \sigma=\text { Stefan Boltzmann constant }\left(1.714 \times 10^{-9} \mathrm{Btu} / \mathrm{hr} \mathrm{ft}^{2} \mathrm{R}^{4}\right) \\
& \varepsilon=\text { emissivity (assumed value of one as ideal emitter) }
\end{aligned}
$$




\subsection{Industrial Powder - Coating Process}

Powder-coating processes involve the cleaning, rinsing, phosphating (improving corrosion protection), rinsing, drying, powder-coating, and curing of parts [20]. The cleaning to drying steps are part of the pre-treatment process, then a part goes into the actual coating processes, followed by the powder application, which requires a spray device with a powder delivery system. The final stage of coating is the curing of the powder-coated parts. Thermal energy is applied for a certain amount of time in order to produce a chemical reaction and form a film on the surface. Powder materials melt when exposed to heat, flow into a level film, then chemically reform and reach the full cure. Heat energy contributes to the chemical reaction and curing. There are several types of ovens, depending on the curing processes, namely convection ovens, infrared ovens, and combination ovens [21]. Heat transfer takes place from the article or paint film to the surrounding air inside the heated chamber throughout the convection oven. Air is heated up in the heated chamber and circulated by fans. This method is suitable for large and irregular-shaped objects. Radiation ovens are known as infrared ovens. In this method, infrared radiation is emitted, which heats up the paint film or surface of an object. Infrared bulbs or infrared electric heaters work as a source where suitable reflectors directed this infrared emission to the object. This surface-heating process is suitable for objects that have simple and straight geometric shapes. Combination ovens are a combination of convection and infrared ovens [22].

\subsection{Cure Dynamics of Powder Coating and Reducing Energy Use}

The oven is a major piece of processing equipment in powder-coating and food-processing companies. The processing time depends on the curing dynamics. Curing dynamics is a changing process through chemical reactions and kinetics of the organic binder between paint and 
substrate metal [23]. Another dependent variable is temperature. Therefore, temperature and time are two important variables of the curing process. Other variables include concentration, particle size, and catalyst. Bruno Fawer developed a mathematical formula [23] for this based on the trial-and-error method. This formula is widely used in convection ovens, though it is not fully supported by the cure dynamics theorem. The formula is:

$\mathrm{t}_{\mathrm{DT}}=\left(\mathrm{t}_{\mathrm{BUT}}+\mathrm{t}_{1}\right)=\mathrm{t}_{\mathrm{BUT}}+\frac{t_{0}}{1.024\left[ \pm \Delta T\left({ }^{\circ} \mathrm{F}\right)\right]}$

Where,

$$
\begin{aligned}
& \mathrm{t}_{\mathrm{DT}}=\text { oven dwell time }[\mathrm{min}] \\
& \mathrm{t}_{\mathrm{BUT}}=\text { oven bring-up time (known or assumed) [min] } \\
& \mathrm{t}_{1}=\text { new cure time after temperature change }[\mathrm{min}] \\
& \mathrm{t}_{0}=\text { cure time after temperature change }[\mathrm{min}] \\
& \Delta \mathrm{T}=\text { new temperature minus initial (base) temperature }\left[{ }^{\circ} \mathrm{F}\right]
\end{aligned}
$$

The processing time, called the dwell time, is defined as the total time a part remains in the cure oven. The total time is made up of two parts: bring-up time and cure time. The bring-up time is the time it takes for a part to reach the cure temperature, while the cure time is the time it takes to cure and settle. There is still confusion with respect to defining dwell time because people in a laboratory environment have stated that oven dwell time and cure time are essentially the same [23]. The bring-up time is a known or assumed parameter determined through trial and error. Therefore, only cure time can be calculated by this formula. Dwell time is a critical phenomenon that can balance conveyor speed (material handling speed), setup temperature, and energy 
consumption. Therefore, to minimize heat requirements, dwell time for quality parts with specific coatings or specific food processing is required [24].

\subsection{Reducing energy use in powder coating system}

Ovens are the major processing equipment in powder coating companies. The finishing process consumed half the total plant's energy [25]. Natural gas is the highest energy used followed by electricity. Therefore, energy cost is a major concern in production price of powder coating companies. Raising energy costs significantly affects production cost and profitability of this finishing process companies [25]. From 2002 to 2006, the cost of energy increased from $\$ 39,500$ to $\$ 107,576$, which is a $275 \%$ increase from 2002 from a single shift coating company [25]. High energy prices significantly increased the importance of minimizing energy use in the powdercoating process. Energy savings can be achieved by following by these strategies [25]:

a. Minimizing high-temperature operation

b. Retain heated air

c. Automate and control

A 75 degree $\left({ }^{\circ} \mathrm{F}\right)$ cuts energy consumption by 700,000 Btu per day, which is $\$ 16,000$ annually [25]. Retaining heated air can cause products to process faster, which will increase oven efficiency. This increases production rate, shortens oven time, and reduces oven temperature. Thus, upgrading or existing ovens with air barrier heat seals provides multiple benefits. Heat sealing ovens can reduce energy usage by half, which provides less than one year's payback period. Upgrading control ensures effective product cleaning and coating, which ensures consistent high-quality finish. A study found that applying the improvement measures described above can reduce plant's energy usage by $25 \%$ [25]. 


\subsection{Curing Oven Basics}

The curing oven is the major processing equipment at powder coating companies, and consumes the majority of the plant's energy. This is the final process of painting and coating. The curing oven raises the temperature of the product being cured and holds it at the required temperature for an amount of time suggested by coating suppliers. The time and temperature are determined by coating manufacturers or suppliers based on chemical composition and metal substrate. There are other factors affecting curing time and temperature, including line speed, product size, hanger spacing, product and conveyor weight, and oven windows. The average time required to achieve curing is 20 minutes [26]. However, time and temperature are not the only variables for curing; many other variables affect curing quality and energy consumption. Parameters to consider when estimating energy consumption include: product energy consumption, radiation energy loss through enclosed panels, energy consumption by conveyor and hanger, energy loss through air seals or openings, fresh air requirements for burners, continuous exhaust for safety requirements, and release of coating materials (if any volatile material is being used with the coating material) [26]. To estimate moving product and conveyor load weight, the following equations can be used.

\section{Assumptions:}

A production rate of 600 parts per hour.

Each carrier holds two parts.

Required number of carriers per hour is $600 / 2=300$ carriers per hour

Required number of carriers per minute $=300 / 60=5$ carriers per minute

Carrier spacing of 36 inches or 3 feet.

Five carriers per minute $\mathrm{x} 3 \mathrm{ft} .=15 \mathrm{ft} / \mathrm{min}$ 
Example:

Conveyor length $=$ ware center $\mathrm{x}$ required production.

$=3[\mathrm{ft}] \times 1,.000[$ number per shift $]=3,000[\mathrm{ft} / \mathrm{shift}]$

Conveyor speed $=3,000[\mathrm{ft}$ per shift $] / 7.5[\mathrm{hrs}$. per shift $]=400[\mathrm{ft} / \mathrm{hour}]=6.67[\mathrm{ft} / \mathrm{min}]$

Assumptions:

Product weight $=[\mathrm{lb}]$

Unit carrier weight $=[\mathrm{lb}]$

Conveyor weight $=[\mathrm{lb}]$

Design conveyor speed $=[\mathrm{fpm}]$

Unit product per hour $=$ conveyor speed $[\mathrm{fpm}] \times$ x 60/ware center $[\mathrm{ft}]=.[$ number per $\mathrm{hr}$.

Lbs product per hour $=$ units product per $\mathrm{hr}$. [number per $\mathrm{hr}$.$] x product weight [\mathrm{lb}]=\mathrm{lb} / \mathrm{hr}$.]

Lbs hanger per hour $=$ unit hanger weight $[\mathrm{lb}] \mathrm{x}$ unit per hour $[\mathrm{unit} / \mathrm{hr}]=.[\mathrm{lb} / \mathrm{hr}$.

Lbs conveyor per hour $=$ conveyor weight $/ \mathrm{ft} .[\mathrm{lb}]$ x conveyor speed fpm x $60=[\mathrm{lb} / \mathrm{hr}$.

\subsection{PRISM Analysis}

The Princeton Scorekeeping Method (PRISM) is a reliable method of energy data analysis for potential energy savings. It is a dependable tool with which to evaluate the effectiveness of retrofits or energy-conservation methods implemented on buildings in the United States. The software and methods were designed by Princeton University in 1984 and then later modified to best utilize the available utility data. Heating and cooling models and automated data correction were added subsequently [27]. 
The PRISM method is a procedure that uses utility billing data from periods before and after installation of industry retrofit measures and average daily temperature data from local weather stations to determine whether there are adjusted energy savings. This results in weatherization programs. This method uses regression analysis to produce pre-weatherization and postweatherization normalized annual consumption values for each industry analyzed, and the difference between these values provides the normalized annual savings for that particular industry $[27,28,29]$.

PRISM assumes that the energy consumption base load remains the same for the whole year. This base load includes lighting, appliances, and domestic hot water. The seasonal load with respect to non-heating has been ignored in PRISM analysis. Usually the highest non-heating consumption occurs during winter, which is caused by increasing demands in water heating, cooking, lighting, clothes drying, etc. A study shows that the difference between non-heating consumption between winter and summer can be up to $20 \%$ [30, 31, 32]. Those changes are linked with seasonal changes similar to space heating and cooling [30, 31, 32]. Therefore, nonheating consumption methodically adds onto the space heating or cooling loads [30, 31, 32].

Because it analyzes a set of data through nonlinear regression, PRISM is an important tool for research. It's a simple method that can represent a curve in a single step. PRISM is a good tool for getting many folds of output from a single selected equation. PRISM does this automatically through the given equation and displays the results as a table, i.e., draws a curve on the graph and interpolates unknown values [28]. PRISM provides weather-adjusted normalized annual consumption (NAC) [33]. This gives two indices at the same time: one being the NAC index, and the other being the best reference temperature of the building being analyzed. In this regression analysis, there are two variables: NAC, which is a dependent variable, and 
HDD/cooling degree day (CDD), which is the independent variable. The correlation between these two variables is expressed by the coefficient of correlation $\mathrm{R}^{2}$. The correlation coefficient explains the behavior of one variable with another. The $\mathrm{R}^{2}$ value ranges from 0 to 1 . The value 0 indicates no relation between these variables, and the value 1 indicates a perfect relationship between these two variables. It is evident that an $\mathrm{R}^{2}$ value of more than 0.7 is the more reliable relation between these two variables [33]. This method is utilized for many purposes, including reference temperature, energy-consumption trends, and weather-adjusted normalized annual energy consumption.

\subsection{Simple Ratio-Based Weather Normalization Method}

Simple ratio-based weather normalization (SRWN) is another method of estimating heating energy requirements. In this method, HDDs are used for the analysis. HDDs are a simplified form of historical weather data. They commonly include monitoring, targeting, and modeling the relationship between energy consumption and outside air temperature. HDDs are commonly used to calculate the weather normalization of energy consumption. Weather normalization or weather correction can show energy consumption from different periods and places with different weather conditions.

The estimated energy consumption is calculated using the Equation 2.14 [33].

$\mathrm{E}=\frac{\mathrm{Ea}}{\mathrm{HDDa}} \mathrm{X} \mathrm{HDD}_{\mathrm{L}}$

Where,

$$
\begin{aligned}
& \mathrm{E}=\text { normalized annual natural gas consumption }\left[\mathrm{m}^{3} / \text { year or Btu/year }\right] \\
& \mathrm{Ea}=\text { actual natural gas consumption }\left[\mathrm{m}^{3} / \text { year or Btu/year }\right]
\end{aligned}
$$




$$
\begin{aligned}
& \mathrm{HDDa}=\text { actual HDD of the billing period }\left[{ }^{\circ} \mathrm{F} \text { day }\right] \\
& \mathrm{HDD}_{\mathrm{L}}=\text { long-term annual HDD }\left[{ }^{\circ} \mathrm{F} \text { day }\right]
\end{aligned}
$$

In the degree-day, the base temperature, balance point, or reference temperature of a building is the outside temperature above which the building doesn't require heating. Different industry buildings have different base temperatures [34]. For the purpose of calculating normalized energy consumption, HDD is essential. If for any reason it is not obtained with a suitable base temperature, it can be obtained with mean air-temperature data (e.g., monthly readings of the mean air temperature) and an assumed base temperature (set-up temperature); these results approximate degree day. This degree day can be obtained by using Hitchin's formula, which is shown in Equation 2.15 [35].

Average degree days per day $=\frac{T_{\text {base }}-T_{\text {mean }}}{1-e^{-k\left(t_{\text {base }}-t_{\text {mean }}\right)}}$

Where,

$$
\begin{aligned}
& \mathrm{T}_{\text {base }}=\text { base temperature }\left[{ }^{\circ} \mathrm{F}\right] \\
& \mathrm{T}_{\text {mean }}=\text { mean outside air temperature }\left[{ }^{\circ} \mathrm{F}\right] \\
& \mathrm{k}=\text { constant }(0.71)
\end{aligned}
$$

This is an alternative methods of calculating degree days from the mean daily temperature where limited data are available. The relation can be plotted in Excel, which provides a trend and $\mathrm{R}^{2}$ value. From this value, conclusions about energy efficiency can be drawn.

\subsection{Shipping and Receiving Door-Related Energy Consumption}

The shipping and receiving door location, opening time, and opening frequency also play an important role with respect to energy-saving opportunities. This activity is important for every 
industry. A model of air infiltration through the door opening was developed to estimate the energy-saving impacts as stated in the American Society of Heating, Refrigerating, and AirConditioning Engineers' (ASHRAE) energy standard ASHRAE 90.1-2007. The energy-saving opportunity regarding door openings can be calculated where air flow rates have already been estimated [36]. The door-opening frequency for different types of buildings was estimated based on available data and occupancy data. In ASHRAE 90.1-2007, the energy savings for each building and each climatic location were estimated. The research shows that strip malls, standalone retail businesses, quick service restaurants, and sit-down restaurants have a larger percentage of energy savings as compared to other buildings which have less frequency of door opening [36, 37]. Air infiltration through door openings can be determined by type of door, usage of buildings, door openings, wind speed, and building pressure differences. The air infiltration can be determined by the Equation 2.16 [36]:

$$
Q=C_{A} A R_{\mathrm{p}}
$$

Where,

$$
\begin{aligned}
& \mathrm{Q}=\text { is air flow rate (cubic feet per minute, or CFM) } \\
& C_{A}=\text { is air flow coefficient }\left(\mathrm{CFM} / \mathrm{ft}^{2} \text {-(in. of water) } 0.5\right. \text { ) } \\
& \mathrm{A}=\text { is area of the door opening }\left(\mathrm{ft}^{2}\right) \\
& \mathrm{R}_{\mathrm{p}}=\text { is a pressure factor (in. of water } 0.5 \text { ) }
\end{aligned}
$$

Energy loss due to air infiltration through a shipping and receiving door can be determined through ventilation energy consumption analysis. 


\subsection{Square-Foot Area Energy Consumption Method}

Shape and size are important considerations in energy-efficient building designs due to their significant impact on energy performance. This decision has to be made during the conceptual stage. A building that is well-shaped, is well-oriented, has a good envelope, is well-configured, and has a high-quality design can consume $40 \%$ less energy than a poorly designed one [38]. The building shape and orientation are two of the most important factors during the conceptual stage of the design process. This design and orientation of the envelope satisfies two performance criteria: maximum daylight use and minimum operating energy consumption. There is a case study in which a typical pentagon-shaped floor showed optimum energy usages than a multiobjective generic algorithm [38, 39]. Analysis of square footage could provide an easier way to compare and benchmark the energy efficiency of a similar type of processing facility.

\subsection{Estimating Non-productive Energy Consumption}

The non- productive energy determined for each facility is the energy extrapolated to zero production in these regression models. Non-productive energy consumption is an important aspect in analyzing the potential saving opportunities in the manufacturing sector. From this research, an important technique for estimating the non-productive energy (also known as overhead energy) in industrial and manufacturing buildings will be analyzed [40]. This process is based on regression analysis on monthly building energy use versus the monthly production rate. The monthly average production data of each facility corresponds to average total building energy use (productive and non-productive). The energy at zero production as a percentage of the average production energy is the non-productive energy percentage [40]. The non-productive 
energy consumption and productive energy consumption (identical facility) can be determined and used for benchmarking the energy-efficiency of facility units.

\subsection{Production Scheduling and Shift Optimization for Energy Optimization}

Meeting due dates and reducing tardiness have always been important objectives of scheduling in manufacturing companies. Both tardiness and earliness have direct and indirect penalties on a company's profitability [41] and add more costs as a result of increased energy consumption. There are many algorithms for operation hour optimization and scheduling of jobs in single or Nmachines [42]. Among them, a single machine with no tardiness issues would be the best method of utilizing productive time. However, decision makers face the issue of selecting which algorithm is best suited to solving their scheduling problems [41]. The first is an " $n$ " job, a sequencing algorithm for one machine for minimizing the number of late jobs, which is the simplest to reduce late jobs [43]. Another popular algorithm is for scheduling one machine to minimize the maximum earliness and the number of tardy jobs [44], which is more appropriate for scheduling in powder-coating and food-processing companies. This algorithm provides a minimized maximum earliness and a minimum number of tardy jobs for an industrial plant. An oven is considered one machine. Shift changes, product changes, and color changes can be considered in this algorithm. Energy consumption is minimized as a result of an optimal production schedule. Fray et al. pointed out that job earliness creates inventory costs and contributes to additional energy consumption [44]. This could be another field of research based on process type and identity. However, the process time and schedule of production can be analyzed in order to establish a potential index on scheduling or shift of operation. 


\subsection{HVAC Energy Optimization}

Heating, ventilation, and air conditioning (HVAC) systems maintain thermal comfort and air quality in buildings. A survey in the U.S. Department of Energy and ASHRAE Standard 62.1 User's manual showed that of the around $40 \%$ of the building energy utilized by HVAC systems, an air-handling system is one of the most energy-intensive components which takes 41.4\% of HVAC energy usages [45]. HVAC demand management cuts down on rising energy demand and costs. Building-management software or an intelligent energy-management device can make this decision automatically. As a result, energy savings can be achieved [46].

\subsection{Thermal Comfort}

The main purpose of HVAC design is to provide indoor thermal comfort for humans. The definition of thermal comfort is "the condition of mind that expresses satisfaction with the thermal environment" (ASHRAE standard 55) [47, 48]. In short, it is these inputs that have an influence on humans physically, physiologically, and psychologically [47]. Human thermal comfort depends on many factors, including temperature and moisture sensation through the skin, deep body temperature, and regular body temperature [48]. Comfort also depends on activity, changing locations, changing thermostat settings, open windows, and indoor spaces. All these factors influence body temperature, skin moisture, and physiological efforts. In general, comfort is achieved when these parameters are minimized. Winslow et al. defined the body as "a skin wittedness index of thermal discomfort indicators." The human body is considered to be two concentric cylinders: a core cylinder, and the skin as a thin cylinder surrounding it [47]. Metabolic activities dissipate heat and are regulated to maintain a normal body temperature. There are two characteristics of body-thermal activities: hyperthermia, in which there is 
insufficient heat dissipating from the body, and hypothermia, in which excessive heat dissipates, resulting in the cooling of the body. A study showed that a skin temperature greater than 45 degrees centigrade or less than 18 degrees centigrade causes pain [48]. Usual comfortable skin temperatures are 33 degrees centigrade to 34 degrees centigrade and decrease with increasing activity [48]. As a result, internal temperatures rise with activity. The comfort temperature in the brain is about 36.8 degrees centigrade. It increases to 37.4 degrees centigrade when walking and 37.9 degrees centigrade when jogging. An internal temperature of less than 28 degrees centigrade can cause serious cardiac arrhythmia and greater than 43 degrees centigrade can cause irreversible brain damage. Considering these facts, the comfort regulation of HVAC design is important. Another factor to be considered is that an adult produces $100 \mathrm{~W}$ of heat when he or she is at rest. This is about $58 \mathrm{~W} / \mathrm{m}^{2}$ and called 1 met. The average skin surface area of a male is about $1.8 \mathrm{~m}^{2}$, and the average skin surface of a female is $1.6 \mathrm{~m}^{2}$ (ASHRAE, 2013) [48]. A person walking is considered to have five times the metabolic rate compared to when in a resting position (about 5 met).

The energy balance equation for humans is shown in Equation 2.17 [48].

$\mathrm{M}-\mathrm{W}=\mathrm{q}_{\mathrm{sk}}+\mathrm{q}_{\mathrm{res}}+\mathrm{S}$

Where,

$$
\begin{aligned}
& \mathrm{M}=\text { rate of metabolic heat production }\left[\mathrm{W} / \mathrm{m}^{2}\right] \\
& \mathrm{W}=\text { rate of mechanical work accomplished }\left[\mathrm{W} / \mathrm{m}^{2}\right] \\
& \mathrm{q}_{\mathrm{sk}}=\text { rate of heat loss from the skin }\left[\mathrm{W} / \mathrm{m}^{2}\right] \\
& \mathrm{q}_{\mathrm{res}}=\text { rate of heat loss through respiration }\left[\mathrm{W} / \mathrm{m}^{2}\right] \\
& \mathrm{S}=\text { Surplus or deficit stored energy }\left[\mathrm{W} / \mathrm{m}^{2}\right]
\end{aligned}
$$

The net heat produced by a human is transferred to the environment through the skin's surface $\left(\mathrm{q}_{\mathrm{sk}}\right)$ and respiratory tract $\left(\mathrm{q}_{\mathrm{res}}\right)$, with the surplus or deficit stored $(\mathrm{S})$, resulting in the body 
temperature rising or falling. In this research study, occupants and their activities were considered in order to standardize the reference temperature setting.

\subsection{Ventilation Analysis}

Ventilation is a process of maintaining indoor air quality in order to achieve human comfort. This is done by changing or replacing air in a space through quality air transfer. Quality of air depends on its temperature, oxygen content, and moisture content, odor, smoke, heat, and carbon monoxide content.

The definition of ventilation is "the intentional movement of air from outside of a building to the inside" (ASHRAE Standard 62.1). Another definition for this in the ASHRAE handbook is "the air used to provide acceptable indoor air quality."

Enbridge Gas Distribution Inc. follows a rule of thumb which is one cubic meter natural gas required for space heating of one square foot facility area in year. This rule of thumb is used for ventilation analysis and this result can be utilized to calculate air changes per hour (ACH). This calculation uses ASHRAE standard 62.1, 2013 [50], where ACH used for ventilation of an industrial plant is $0.18 \mathrm{CFM} / \mathrm{ft}^{2}$.

The following method can be used to calculate ventilation. Initially, the total plant's natural gas consumption is calculated:

Total natural gas consumption $\left[\mathrm{m}^{3} /\right.$ year $]=$ average process load $\left[\mathrm{m}^{3} /\right.$ year $]+$ average seasonal load $\left[\mathrm{m}^{3} /\right.$ year]

Then,

Total seasonal load $=$ space heating $\left[\mathrm{m}^{3} /\right.$ year $]+$ ventilation $\left[\mathrm{m}^{3} /\right.$ year $]$

Space heating $=$ rule of thumb by Enbridge Gas Distribution Inc. 
1 square foot requires $1 \mathrm{~m}^{3}$ of natural gas per year

So, ventilation $=$ total seasonal load $\left[\mathrm{m}^{3} /\right.$ year $]-$ space heating $\left[\mathrm{m}^{3} /\right.$ year $]$

Therefore,

ventilation $\left[\mathrm{m}^{3} /\right.$ year $]=$ operational hrs $[\mathrm{hr} / \mathrm{yr}] \times 1.08\left[\mathrm{Btu}-\mathrm{min} / \mathrm{ft}^{3}{ }^{\circ} \mathrm{F} \mathrm{hr}\right] \mathrm{x} \mathrm{CFM} \times \Delta \mathrm{T}\left[{ }^{\circ} \mathrm{F}\right]$

Now, air changes per hour $(\mathrm{ACH})=(\mathrm{CFM} \times 60) /$ volume

\subsection{Case Study on Energy Management}

\subsubsection{Advancing Opportunity in Energy Management in Ontario Industrial and Management Sector}

Canadian Manufacturing \& Exporters, in conjunction with the consulting services of Stantec

Consulting, Marbek, and ODYNA, conducted a study to examine energy management opportunities in the manufacturing sector in Ontario. This research report was published on March 17, 2010. The objective of the study was to assess energy-management performance to estimate the economic potential for energy management. Extended research objectives included the benchmarking of greenhouse-gas emissions and the reduction of air contaminants. The reference year for this analysis is 2007 [51].

Five objectives were set in this research project study: (a) reduce operating costs, (b) increase productivity, (c) retain manufacturing jobs and value addition, (d) reduce air emissions, and (e) defer or avoid new energy infrastructure [51]. The scope of work encompassed three performance indicators: energy intensity, technical best practices (TBP), and management best practices (MBP). Energy intensity is the amount of energy used to produce output - for example, 
a kilowatt-hours per ton of product produced. TBP is the production system and efficiency measure that assesses reduction in energy use per unit of production. An example is the installation of a heat recovery boiler, which exhausts gas from the generator in order to reduce process energy. MBPs relate to a manager's actions to reduce energy use. Examples include company policies and plans to reduce energy use.

Energy benchmarking was investigated over selected companies in the GTA. The area of investigation included energy intensity, TBPs, and MBPs. The results showed very low implementation of the TBP method. Thirty-one percent to $42 \%$ of the firms in the sample implemented TBPs and achieved the 75th percentile. Fifty-eight percent of the firms had the opportunity to implement TBPs. Large plants were $10 \%$ more likely to implement TBPs compared to SMEs. TBPs were grouped into three different fields: lighting, process specification, and indirect-process heating. TBP implementation rates on lighting large firms and SMEs were $33 \%$ and $3 \%$, respectively; $43 \%$ and $14 \%$ on process-specific heating, respectively; and $37 \%$ and $21 \%$ on indirect-process heating, respectively. Results showed that fewer than $48 \%$ of the plants implemented MBPs and achieved the 75th percentile. Fifty-two percent of the firms had to implement MBPs. Large firms were $30 \%$ more likely to implement MBPs compare to SMEs. MBPs were divided into three different fields: financing, policy and planning, and monitoring. Large firms and SMEs implemented MBPs at the following rates: $70 \%$ and 20\%, respectively, in the financing field; $42 \%$ and $7 \%$, respectively, in policy and planning; and $46 \%$ and 12\%, respectively, in the monitoring field. A correlation existed between TBPs and MBPs. Research showed that the higher the degree of MBPs implemented, the higher the degree of TBPs implemented [52]. Overall, 22\% of the selected plants implemented both TBPs and MBPs. Individually, TBPs were implemented $40 \%$ more often than MBPs. Sixty-three percent of the 
TBPs and MBPs implemented were in large plants. Two-thirds of SMEs implemented TBPs at a rate of less than $40 \%$. Therefore, a large potential exists for further research in this sector.

\subsubsection{Bottom Line Improvement of Natural Gas Consumption Through Process Ovens: A Case Study by Enbridge Gas Distribution Inc. in Canada's Greater Toronto Area}

Powder-coating ovens or process ovens provide decorative or protective finishes applied on a surface without the aid of solvents or carrier liquids $[53,54,55]$. Dwelling time is the main feature of this process. Dwelling time involves bring-up time and cure time. These processes require heat energy or thermal energy. The low thermal efficiency of an oven is the major concern of this research [23].

A team from Toronto, Canada's Enbridge Gas Distribution Inc. examined industrial process ovens to assess DSM and energy savings. Industrial ovens are usually used for baking, drying, powder-coating, and curing. Enbridge's energy team studied a case on powder-coating companies wherein two types of ovens - dry-off ovens and cure ovens, both of which are heat convection-type ovens-were involved. George Koch Sons, LLC, shows the percentage of energy consumption of ovens by different uses, including pre-treatment heating (38\%), pre-treatment motor $(7 \%)$, air handler (13\%), oven heating (38\%), oven motors $(3 \%)$, and lights or miscellaneous motors (1\%). The energy balance of ovens is shown in Equation $2.23[55,56]$.

$$
\mathrm{E}_{\mathrm{NG} \text { input }}=\mathrm{E}_{\mathrm{p}}+\mathrm{E}_{\mathrm{c}}+\mathrm{E}_{\mathrm{Exh}}+\mathrm{E}_{\text {Shell }}+\mathrm{E}_{\text {Opening }}[\mathrm{Btu} / \mathrm{hr}]
$$

Where,

$$
\begin{aligned}
& \left.E_{N G i n p u t}=\text { energy input of natural gas through burner }[\mathrm{Btu} / \mathrm{hr}]\right] \\
& \left.\mathrm{E}_{\mathrm{p}}=\text { energy consumed by product }[\mathrm{Btu} / \mathrm{hr}]\right]
\end{aligned}
$$




$$
\begin{aligned}
& \left.E_{c}=\text { energy consumed by conveyor }[\mathrm{Btu} / \mathrm{hr}]\right] \\
& \left.E_{E x h}=\text { exhaust energy loss }[\mathrm{Btu} / \mathrm{hr}]\right] \\
& \left.E_{\text {Shell }}=\text { energy loss through shell }[\mathrm{Btu} / \mathrm{hr}]\right] \\
& \left.E_{\text {Open }}=\text { energy loss through oven opening }[\mathrm{Btu} / \mathrm{hr}]\right]
\end{aligned}
$$

Heat loss from an oven is a major concern in this analysis. This happens in many ways, namely through conveyor (material handling) losses, oven opening losses, shell losses, and exhaust losses. Energy required by the product can be determined by the Equation 2.24.

$\mathrm{E}_{\text {Products }}[\mathrm{Btu} / \mathrm{hr}]=\mathrm{m}_{\mathrm{f} \text { products }}[\mathrm{lb} / \mathrm{hr}] \mathrm{x} \mathrm{C}_{\mathrm{p}}\left[\mathrm{Btu} / \mathrm{lb}{ }^{\circ} \mathrm{F}\right] \mathrm{x} \Delta \mathrm{T}\left[{ }^{\circ} \mathrm{F}\right]$

Where,

$$
\begin{aligned}
& E_{\text {Products }}=\text { energy required by the product to cure or process }[\mathrm{Btu} / \mathrm{hr}] \\
& \mathrm{m}_{\mathrm{f} \text { products }}=\text { mass of the product }[\mathrm{lb} / \mathrm{hr}] \\
& \mathrm{C}_{\mathrm{p}}=\text { material's specific heat capacity }\left[\mathrm{Btu} / \mathrm{lb}{ }^{\circ} \mathrm{F}\right] \\
& \Delta \mathrm{T}=\text { temperature difference of material between before and after the process }\left[{ }^{\circ} \mathrm{F}\right]
\end{aligned}
$$

Conveyor energy loss or material handling (MH) loss contributes in two ways: firstly, through conveyor chain loss, and secondly, through conveyor hanger loss. Both losses can be named MH loss. This MH energy loss is determined by the Equation 2.25 .

$\mathrm{E}_{\mathrm{MH}}[\mathrm{Btu} / \mathrm{hr}]=\mathrm{m}_{\mathrm{MH}}[\mathrm{lb} / \mathrm{hr}] \times \mathrm{C}_{\mathrm{p}}\left[\mathrm{Btu} / \mathrm{lb}{ }^{\circ} \mathrm{F}\right] \times{ }^{\circ} \mathrm{T}\left[{ }^{\circ} \mathrm{F}\right]$

Where,

$\mathrm{E}_{\mathrm{MH}}=$ energy required by the material handling equipment $[\mathrm{Btu} / \mathrm{hr}]$ 
$\mathrm{m}_{\mathrm{MH}}=$ mass of the material handling equipment $[\mathrm{lb} / \mathrm{hr}]$

$\mathrm{C}_{\mathrm{p}}=$ material's specific heat capacity $\left[\mathrm{Btu} / \mathrm{lb}{ }^{\circ} \mathrm{F}\right]$

$\Delta \mathrm{T}=$ temperature difference of material handling equipment before and after the process

$\left[{ }^{\circ} \mathrm{F}\right]$

Continuous flow dry-off ovens and cure ovens usually have two openings. One is at a beginning of a process, and the other is at an exit of a process side. There is a definite loss of heat energy, which is approximately $1 \%$ to $3 \%$ of the total energy consumption of an oven. This is calculated by the Equation 2.26 .

$\mathrm{E}_{\text {open }}=\mathrm{Q}_{\text {open }}[\mathrm{CFM}] \times 1.08 \times \Delta \mathrm{T}\left[{ }^{\circ} \mathrm{F}\right]$

Where,

$\mathrm{E}_{\mathrm{open}}=$ energy loss due to opening of oven $[\mathrm{Btu} / \mathrm{hr}]$

$\mathrm{Q}_{\mathrm{open}}=$ flow rate of dry flue gas from opening in CFM

$\Delta \mathrm{T}=$ temperature difference between the opening part of an oven and indoor temperature of a facility $\left[{ }^{\circ} \mathrm{F}\right]$

(Explanation of 1.08. In general for standard air $\rho=0.075 \mathrm{lb} / \mathrm{ft}^{3}$. For dry air $\mathrm{C}_{\mathrm{p}}=0.24 \mathrm{Btu} / \mathrm{lb}{ }^{\circ} \mathrm{F}$. Therefore, the constant's value is

$\left.=\frac{0.75 \mathrm{lb}}{f t 3} \times \frac{0.75 \mathrm{Btu}}{l b^{\circ} \mathrm{F}} \times \frac{60 \mathrm{~min}}{\text { hour }}=1.08 \mathrm{Btu}-\mathrm{min} / \mathrm{ft}^{3} \mathrm{o} \mathrm{F} \mathrm{hr}\right)$ 
The shell is an enclosure of an oven, and it can be made in different geometric shapes and have more than one layer. The geometric shape and number of layers depend on its uses. Shells usually protect heat loss. Shell energy loss can be calculated by the Equation 2.27.

$\mathrm{E}_{\text {shell }}=\mathrm{A}_{\text {shell }}\left[\mathrm{ft}^{2}\right] \mathrm{x}\left[\mathrm{Btu} / \mathrm{ft}^{2}{ }^{\circ} \mathrm{F}\right] \times \Delta \mathrm{T}\left[{ }^{\circ} \mathrm{F}\right]$

Where,

$E_{\text {Shell }}=$ energy loss from oven shell [Btu]

$\mathrm{U}=$ overall heat transfer co-efficient of oven shell material $\left[\mathrm{Btu} / \mathrm{ft}^{2}{ }^{\circ} \mathrm{F}\right]$

$\Delta \mathrm{T}=$ temperature difference between the opening part of an oven and indoor temperature of a facility $\left[{ }^{\circ} \mathrm{F}\right]$

Table 2.1: Heat loss factor on panel thickness [57]

\begin{tabular}{|c|c|c|c|c|c|}
\hline Panel thickness (inches) & 3 & 4 & 5 & 6 & 8 \\
\hline $\begin{array}{c}\text { Loss factor (these insulation factor assume that the } \\
\text { insulating material is rated as 4-pound density) }\end{array}$ & 0.40 & 0.35 & 0.30 & 0.25 & 0.20 \\
\hline
\end{tabular}

Exhaust contributes to heat loss in an oven. Burnt gases travel through the exhaust system as a result of combustion. Theoretically, waste created through combustion is expelled from the oven, where useful heat energy and toxic gas are present. Energy loss through exhaust can be calculated by Equation 2.19, where the exhaust flow rate and temperature differential between exhaust air temperature and ambient temperature are required. The exhaust energy can be found through Equation 2.28.

$\mathrm{E}_{\text {Exhaust }}=\mathrm{Q}$ Exhaust $[\mathrm{CFM}$ or SCFM $] \times 1.08 \times \Delta \mathrm{T}\left[{ }^{\circ} \mathrm{F}\right]$ 
Where,

$\mathrm{E}_{\text {Exhaust }}=$ energy loss due to exhaust from oven $[\mathrm{Btu} / \mathrm{hr}]$

$\mathrm{Q}_{\text {Exhaust }}=$ flow rate of dry flue gas from exhaust from oven in CFM or SCFM

$\Delta \mathrm{T}=$ temperature difference between the opening part of an oven and indoor temperature of a facility $\left[{ }^{\circ} \mathrm{F}\right]$

Purge is another kind of energy loss from an oven. This is a definite requirement to maintain safety and expel partially burned gases before an oven reached to operating temperature. Different manufacturers recommended different purge times and purge frequencies, which depend on oven volumes and operating temperatures. Usually there were 4-6 purge observed in an oven of audited industrial plants. This purge time can be calculated by Equation 2.29.

$t_{\text {purge }}[\min ]=\frac{4 \times \mathrm{V}_{\text {Oven }}}{\mathrm{VF}_{\text {exh }}}$

Where,

$$
\begin{aligned}
& \mathrm{t}_{\text {purge }}=\text { purge time in minute } \\
& \mathrm{V}_{\text {oven }}=\text { volume of oven }\left[\mathrm{ft}^{3}\right] \\
& \mathrm{VF}_{\text {exh }}=\text { exhaust volume }[\mathrm{SCFM}]
\end{aligned}
$$

Another requirement is to calculate the exhaust ventilation while the oven is running. This calculation requires the correction factor $(\mathrm{CF})$ at the running temperature. $\mathrm{CF}$ can be estimated by Equation 2.30 .

$$
\text { Oven } \mathrm{CF}=\frac{\left(\mathrm{T}_{\mathrm{Oven}}+460\right)}{\left(\mathrm{T}_{\mathrm{ref}}+460\right)}
$$


Where,

$$
\begin{aligned}
& \mathrm{T}_{\text {oven }}=\text { running temperature of oven }\left[{ }^{\circ} \mathrm{F}\right] \\
& \mathrm{T}_{\text {ref }}=\text { facility reference temperature }\left[{ }^{\circ} \mathrm{F}\right]
\end{aligned}
$$

Exhaust at constant volume can be estimated by Equation 2.31.

$\mathrm{Q}(\mathrm{SCFM})=\frac{\text { number of purge } \mathrm{x} \text { oven volume }}{\text { purge time }}$

Most gas meters measure the volume of gas at the existing pressure and temperature. The value of the gas (i.e., heat content) is referred to in gas measurement as the standard volume or volume at standard conditions of pressure and temperature. Charles' Law describes the effect of temperature on volume, stating, "At constant pressure, a volume of a given mass of ideal gas increases or decreases by the same factor as its temperature on the absolute temperature scale" [58]. In other words, as the temperature increases, the gas expands, and as the temperature decreases, the gas contracts. Expanding temperature using the Charles' Law temperature correction factor can be calculated as [58]:

Temperature Correction Factor $(\mathrm{CF})=\frac{\text { Base Temperature }+460}{\text { Flow Temperature }+460}$

(Absolute temperature conversion are ${ }^{\circ} \mathrm{R}={ }^{\circ} \mathrm{F}+460$ )

\subsubsection{A Case Study: Improving Energy Performance in Canada}

The research performed aimed to improve energy efficiency in earliest possible time in Canada. This research showed the most affordable and most effective way to control energy costs. [59] An energy-efficiency program was implemented through a regulation named the Energy Efficiency Act [59], helping to control energy costs in homes, buildings, industries, and vehicles. 
At the same time, renewable energy production was encouraged for clean energy production. Energy intensity was the outcome by which changes in the energy uses can be estimated. This research found that $38 \%$ of total secondary energy used was consumed in the industrial sector, $29.5 \%$ was consumed in the transportation sector, $16.5 \%$ was consumed in residential sector, $14 \%$ was consumed in the commercial sector, and $2 \%$ was consumed in the agricultural sector. The Energy Efficiency Act gives an enforcement power to government of Canada to become overall energy efficient. [59]

\subsubsection{A Case Study: An Energy-Efficiency Program for Swedish Industrial Small and Medium-Sized Enterprises}

Research was performed in Sweden to fulfill the 20-20 target energy-efficiency program created by the European Union. [60] As part of this research, SMEs reduced their energy use to 700 to 1400 GWh annually. [60] This energy efficiency was achieved through energy audits and longterm agreements. Programs helped guide potential energy savings after an ex-ante evaluation program. The European Commission's Council Regulation No. 1083/2006 defines an ex-ante evaluation as the process of developing a policy program performed before the implementation

of main programs to stakeholders. [60] After implementing the ex-ante program, an annual savings of 700 to $1400 \mathrm{GWh}$ was achieved by Swedish SMEs. The cost effectiveness achieved by the ex-ante evaluation was 0.25 to 0.50 eurocent $/ \mathrm{kWh}$. [60] 
The methodology is based on utility bills and other available data collected through energy audits. The purpose was to perform process energy consumption analysis and develop meaningful indicators, which estimate consumption patterns and potential savings.

\subsection{Research Methodology}

Figure 3.1 shows the research flow diagram. The energy consumption during different parts of processes is analyzed to identify trends. 

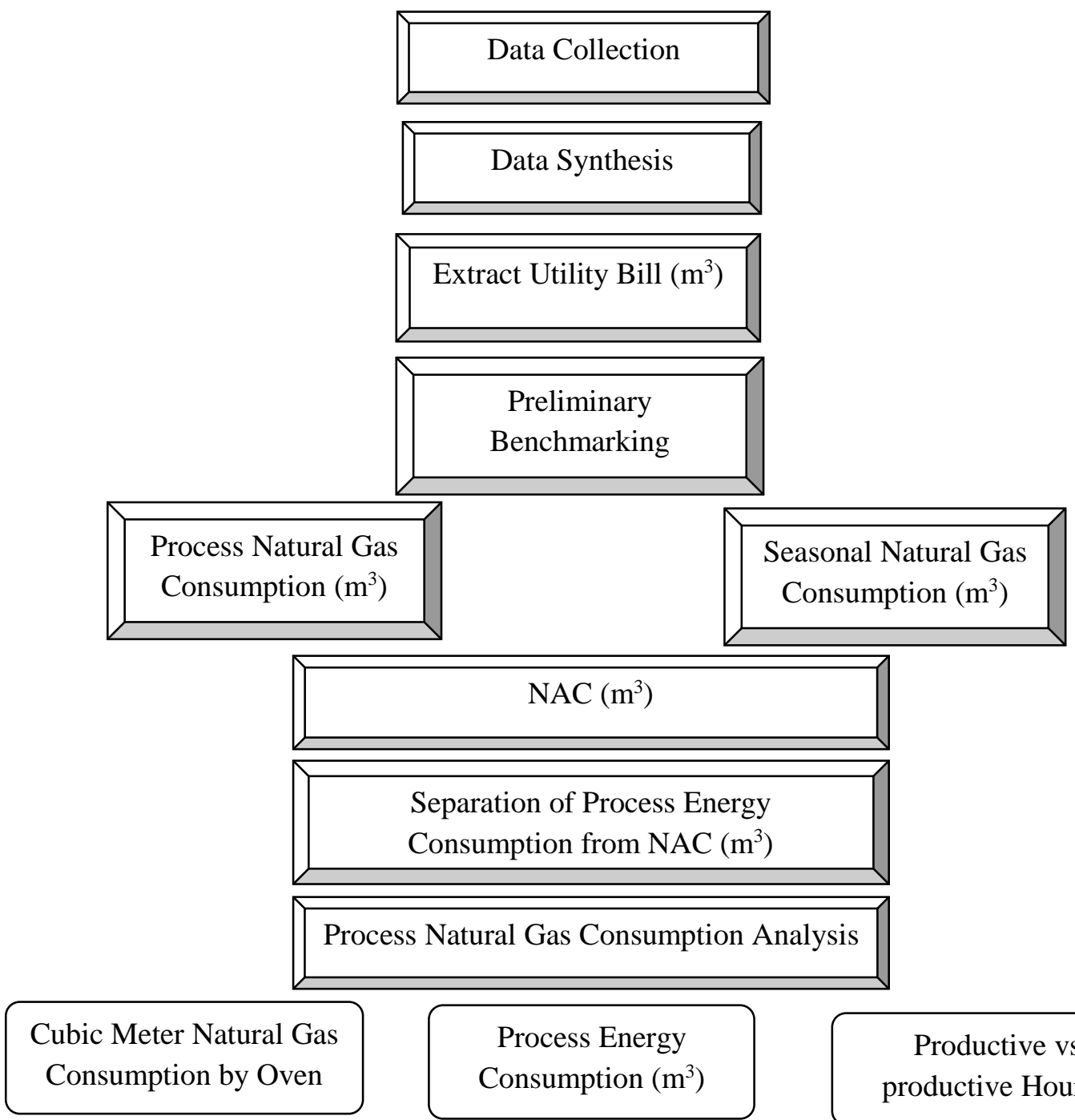

Productive vs. Nonproductive Hours Energy

Exhaust Energy

Consumption $\left(\mathrm{m}^{3}\right)$

Holiday Energy

Consumption $\left(\mathrm{m}^{3}\right)$

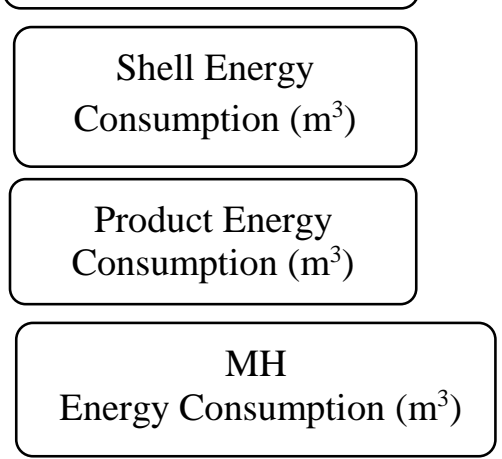

Oven Opening
Energy Consumption $\left(\mathrm{m}^{3}\right)$

Miscellaneous Energy Consumption $\left(\mathrm{m}^{3}\right)$

Figure 3.1: Flow diagram of research program to investigate energy-saving opportunities of SMEs in the GTA 


\subsection{Process Flow of Powder Coating Company}

Powder coating is a dry finishing process that became trendy due to its high quality, durability, maximum production, improved efficiency, and environmental compliance. Powder coating is based on polymer resin systems including curative, pigments, leveling agents, flow modifiers, and other additives. These melt after mixing, and then cool to make a uniform powder. These powders are used as a coating on metal substrate through an electrostatic spray deposition. The process usually observed in the powder coating process is presented in Figure 3.2.

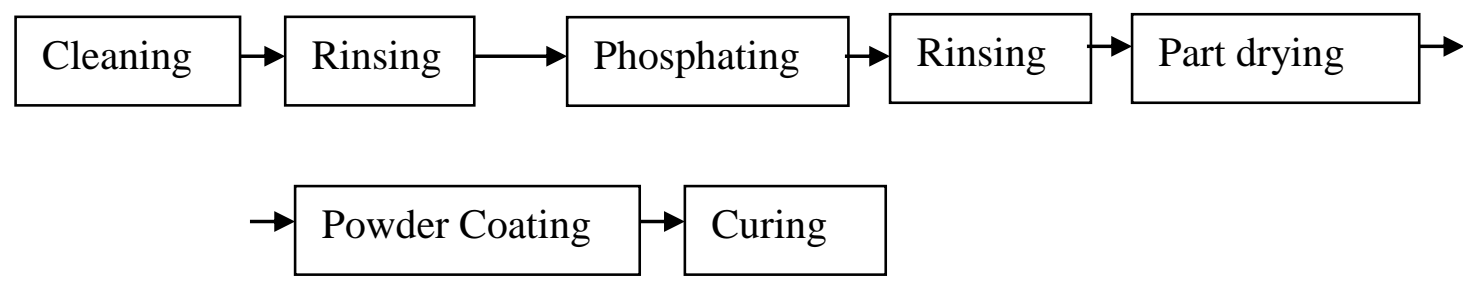

Figure 3.2: Process flow diagram of powder coating company (AAWIL)

The cleaning process typically uses an alkaline cleaner based on substrate. Some of the plants observed use phosphating to protect from corrosion. In this process, drying and curing are the energy-intensive operations.

\subsection{Energy Audit}

Energy audits provide accountability of energy use [61]. Energy audits quantify the amount of energy consumption in different systems in a firm. The evaluation of the consumption pattern is the objective of energy-management activities achieved through energy audits [61]. This accountability provides a baseline for comparison. Comparing energy information illuminates 
the performance of firms. Furthermore, energy audits provide options to reduce energy consumption or become energy efficient.

\subsection{Primary Data Collection and Site Selection}

The first step of energy consumption analysis is to collect required information, or conduct primary data collection. This includes data on energy consumption, production, and facilities. Data from a few other related categories were gathered through on-site energy audits. They are listed here and in Appendix B:

- Specifications of ovens and other production equipment (rated capacities, purge times, exhaust rates, dimensions, conveyor lengths, conveyor speeds, oven materials, etc.)

- Burner capacities

- HVAC specifications and design capacities

- Annual production schedules

- Types of products (dimensions and weights)

- Product and color changes over time

Site and facility selection were based on a screening process by Enbridge Gas Distribution Inc. within the GTA.

\subsection{Data Synthesis}

The synthesis process depends on estimated analysis outcomes. Data from plant managers and on-site audits were gathered for use in subsequent analyses. Other data were gathered from the 
National Fire Protection Association (NFPA) and Technical Standards and Safety Authority (TSSA) to calculate oven exhaust, and minimum purge time assessment [62, 63].

\subsection{Process and Seasonal Energy Consumption}

Utility bills were collected for pre-benchmarking, and process energy consumption and seasonal energy consumption were separated. To evaluate the process energy consumption, summer months' average consumption was considered. The summer month defines "in the Northern Hemisphere the usually warmest season of a year, occurring between spring and autumn and constituting June, July, and August" [64]. To obtain seasonal energy consumption, process energy was subtracted from total utility bills. The vertical axis (y-axis) is the average monthly energy consumption in cubic meters of natural gas, and the horizontal axis (x-axis) is the year and month. The color blue represents seasonal energy consumption, and red represents the average process load in a year. June, July, and August are considered summer months, during which it is assumed no space heating is required [65]. The separation of process and seasonal load is identified in Figure 3.3. In this thesis, 11 audited companies' energy consumption data were used to investigate potential energy-saving opportunities. These analyses were based on published methodology from journals and established heat transfer principles. Major analysis was focused on process energy consumption and industrial ovens. The overall potential savings (cost and energy) from oven has been analyzed in this research. 


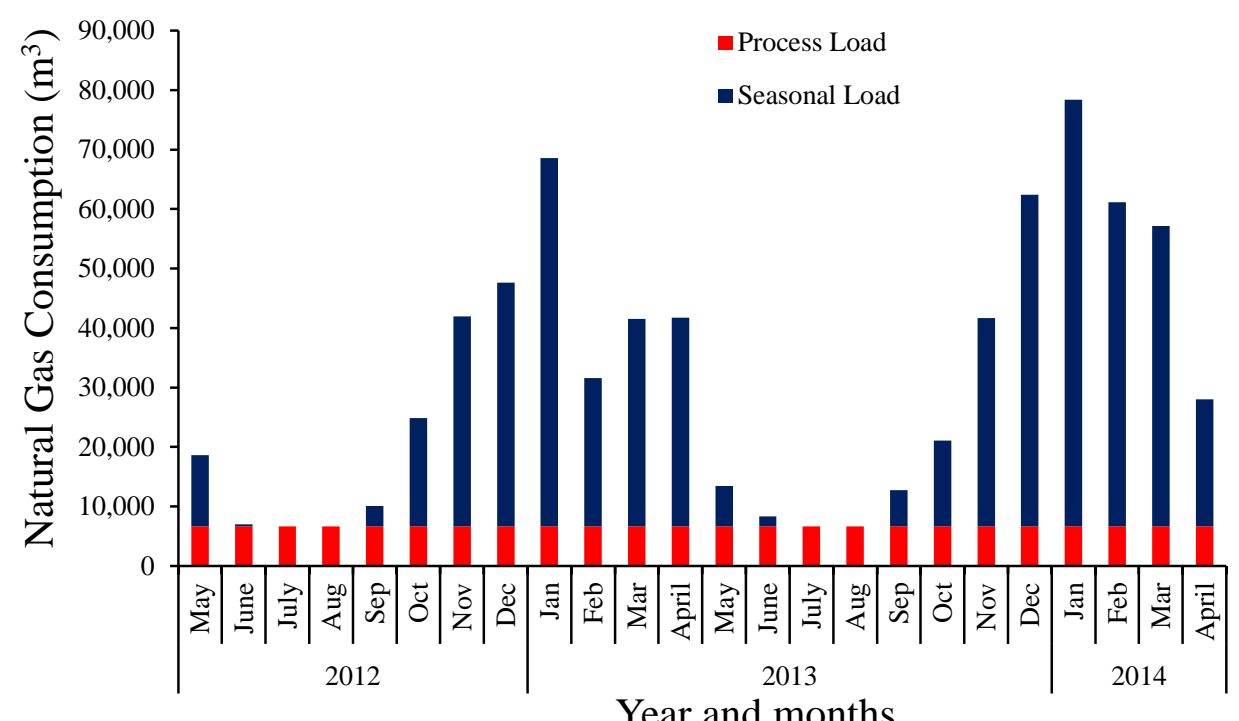

Figure 3.3: Separation of process and seasonal energy consumption (AASPEC)

Figure 3.4 shows an approximation of the oven location, energy losses, process flow, and HVAC flow found during the on-site energy audits. Yellow arrow indicates heat energy loss from a facility.

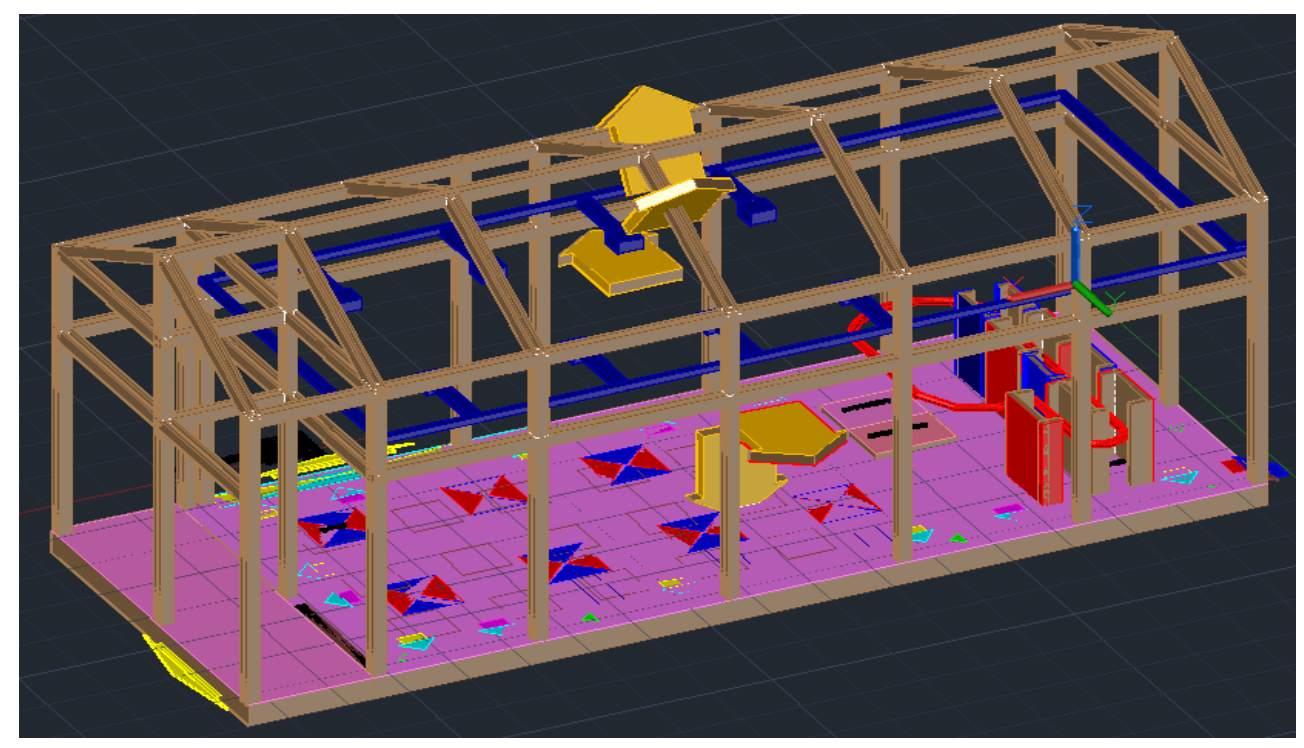

Figure 3.4: Typical industrial layout with HVAC network, process flow, and ovens (simulated based on AASPEC) 
Natural gas consumption, collected from utility bills, was separated into process energy consumption and seasonal consumption. Process energy consumption, marked in yellow in Figure 3.5, was again subdivided based on audit findings:

- Energy consumption by production equipment.

- Energy consumption by boiler/major equipment.

- Oven energy consumption.

- Oven exhaust energy loss.

- Oven process energy consumption.

- Shell energy loss.

- Material handling (MH) energy loss.

- Oven's door opening energy loss.

- Miscellaneous energy consumption

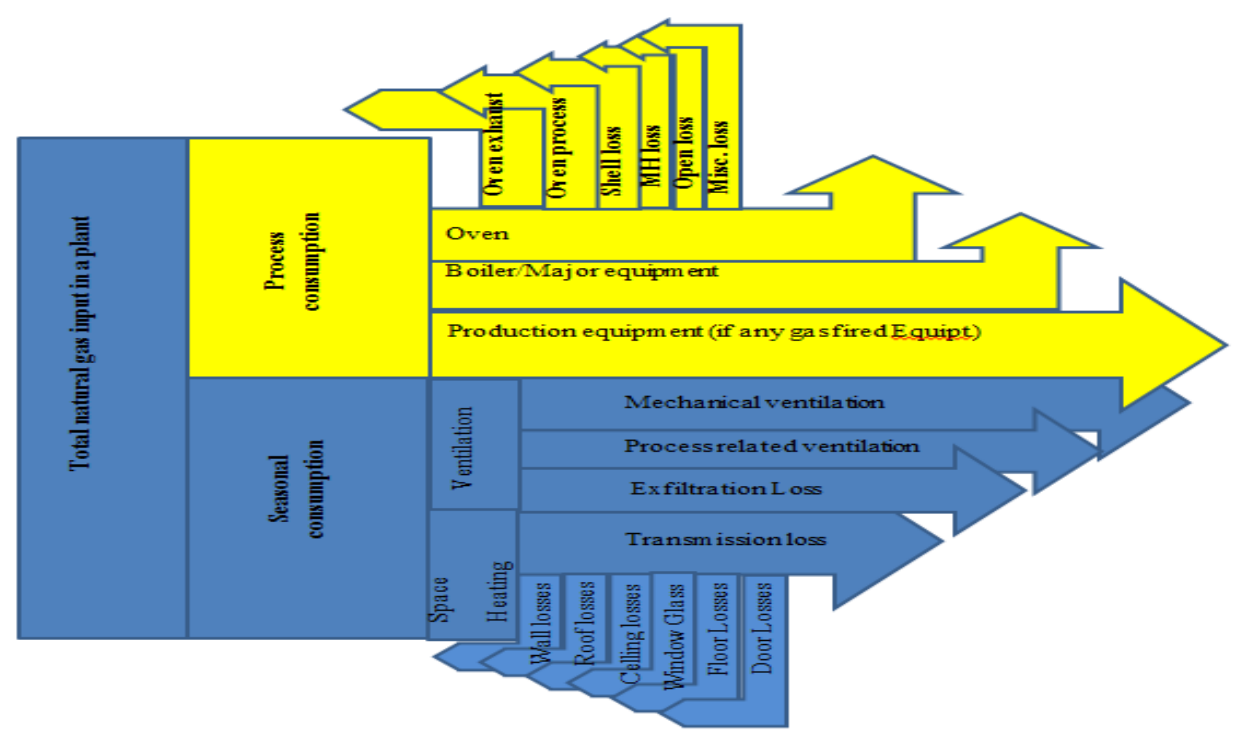

Figure 3.5: Sankey diagram of total energy balance of an industrial plant (AASPEC) 


\subsection{Estimated Reference Temperature by Regression Analysis and Estimated Normalized Annual Consumption}

Energy-savings calculation in engineering does not always correlate with real-world performance. Weather is one of the important differences between engineering energy-savings calculation and real-world performance $[66,67]$. Weather varies from year to year and continues to change. As a result, it is becoming difficult to forecast weather effectively. Therefore, in energy-savings calculation, it is vital to remove the energy consumption due to weather from the total energy consumption, because does not have control. Calculating energy consumption due to weather relies on a reference temperature of individual buildings and can be normalized with historical weather data for realistic estimation. Linear correlation exists between energy consumption and average mean daily outdoor temperature. This shows the performance of space heating systems in a facility. The normalized energy consumption is plotted on the Y-axis and outdoor temperature on the X-axis. A custom Excel analysis shows a line graph with a downward slope. This indicates that as outside temperatures increase, space heating energy consumption decreases.

Internal process heating influences space heating; a variation of HVAC set point temperature and space reference temperature was observed. Figure 3.6 shows that few points close to temperature $67^{\circ} \mathrm{F}$ to $75^{\circ} \mathrm{F}\left(19^{\circ} \mathrm{C}\right.$ to $\left.24^{\circ} \mathrm{C}\right)$ which shows a different trend than other points. From this different trend a reference temperature can be estimated if the reference temperature cannot be calculated by other method. This was used to estimate a new reference temperature for a facility, requires calculating process energy consumption analysis. This shift of reference temperature from set point temperature occurs because of internal heat gain by process machinery. 


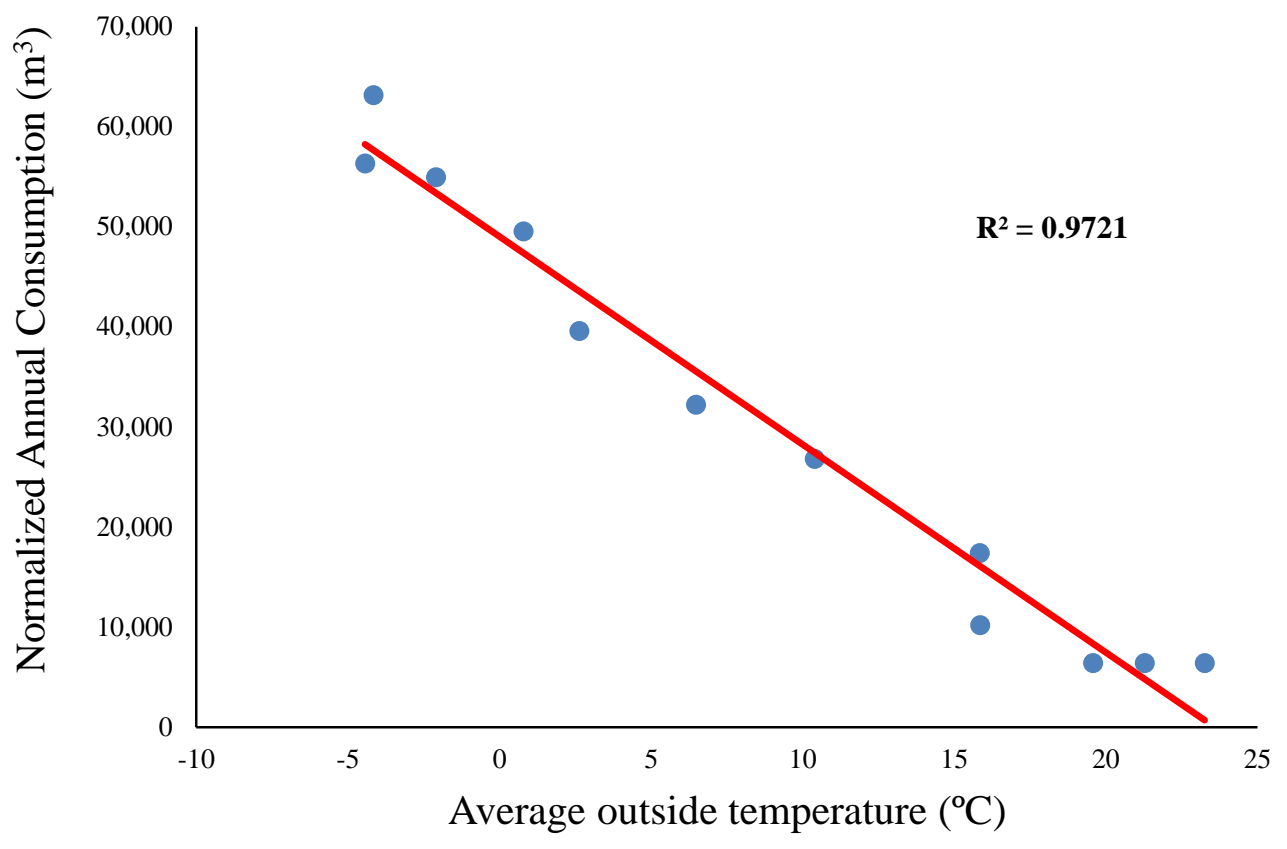

\section{Figure 3.6: Typical regression analysis of outside average temperature and normalized energy consumption (AASPEC)}

Other approaches for determining reference temperature include using PRISM and Excel [68]. PRISM is commercially available software based on statistical procedures that converts common utility billing data into useful weather-adjusted estimates of annual energy use [68, 69, 72-75]. In these methods, actual utility billing data were collected from industrial plants. These billing periods' weather data (outdoor temperature) have been taken from Environment Canada (19842013) [69]. Research analysis was performed in both Excel and PRISM software to verify results. PRISM calculates a reference temperature in order to achieve optimized linear regression [70]. This reference temperature obtained from the statistical approach is influenced by a few factors: facility envelopes, HVAC, production machinery, and appliances. Therefore, optimum reference temperature is a characteristic of a facility [71]. Higher reference temperatures in 
heating-dominated facilities indicate higher space heating requirement at lower outdoor temperatures.

Obtaining the reference temperature in PRISM requires two important data files for each company: daily average outside temperature in Fahrenheit, and monthly energy consumption in any unit (in this analysis, $\mathrm{m}^{3}$ of natural gas is used), showing respective billing dates. These files must be converted to the Windows' Notepad format as described in the PRISM user manual or prepared in an Excel or Notepad.txt file and converted to a Notepad file by PRISM through a readable temperature file (file ends with .TPS in PRISM) and meter file (file ends with .MTR), which are described in Chapter 1 of the PRISM Users' Guide: Reference Manual $[68,70,73]$. After the data file has been successfully prepared, PRISM uses the data to get the heating and cooling reference temperature (TAU, $\tau$ ), NAC, and correlation coefficient $\left(\mathrm{R}^{2}\right)$.

PRISM calculated the NAC value through estimated consumption under average weather conditions [68], which is shown in Equation 3.1. Fels and Reynolds defined "heating-only (HO), cooling-only (CO), and heating-and-cooling (HC) automated models in PRISM" [68].

$\mathrm{NAC}=365 \alpha+\delta_{\mathrm{h}} \beta_{\mathrm{h}} \mathrm{H}_{0}\left(\tau_{h}\right)+\delta_{\mathrm{h}} \beta_{\mathrm{c}} \mathrm{C}_{0}\left(\tau_{c}\right)\left[\mathrm{m}^{3} /\right.$ year $]$

(base level) + (heating part) + (cooling part)

Where,

$$
\begin{aligned}
& \text { NAC }=\text { Normalized annual consumption }\left[\mathrm{m}^{3} / \text { year }\right] \\
& \alpha=\text { base-level consumption }\left[\mathrm{m}^{3} / \mathrm{day}\right][\mathrm{HO}, \mathrm{CO}, \mathrm{HC}] \\
& \beta_{\mathrm{h}}=\text { heating slope }\left[\mathrm{m}^{3} /{ }^{\circ} \mathrm{F}-\text { day }\right][\mathrm{HO}, \mathrm{HC}] \\
& \beta_{\mathrm{c}}=\text { cooling slope }\left[\mathrm{m}^{3} /{ }^{\circ} \mathrm{F}-\mathrm{day}\right][\mathrm{CO}, \mathrm{HC}] \\
& \delta_{\mathrm{h}}=1 \text { for heating only }(\mathrm{HO}) \text { and combined heating and cooling }(\mathrm{HC}) \text { model, otherwise } \\
& \text { zero } \\
& \delta_{\mathrm{h}}=1 \text { for cooling only }(\mathrm{CO}) \text { and combined heating and cooling }(\mathrm{HC}) \text { model, otherwise } \\
& \text { zero }
\end{aligned}
$$


$\tau_{\mathrm{h}}=$ heating reference temperature $\left[{ }^{\circ} \mathrm{F}\right][\mathrm{HO}, \mathrm{HC}]$

$\tau_{\mathrm{c}}=$ cooling reference temperature $\left[{ }^{\circ} \mathrm{F}\right][\mathrm{CO}, \mathrm{HC}]$

$\mathrm{H}_{0}\left(\tau_{\mathrm{h}}\right)=$ Long term average heating degree day per year to the PRISM to estimate reference temperature

$\mathrm{C}_{0}\left(\tau_{\mathrm{c}}\right)=$ Long term average cooling degree day per year to the PRISM to estimate reference temperature

In Equation 3.1, $\delta_{\mathrm{h}}=1$ is estimated for $\mathrm{HO}$ and $\mathrm{HC}$ models and $\delta_{\mathrm{c}}=0$, while $\delta_{\mathrm{c}}=1$ is estimated for the $\mathrm{CO}$ and $\mathrm{HC}$ models and $\delta_{\mathrm{h}}=0$. Long-term heating and cooling degree days per year can be determined by $\mathrm{H}_{0}\left(\tau_{\mathrm{h}}\right)$ and $\mathrm{C}_{0}\left(\tau_{\mathrm{c}}\right)$, respectively. Therefore, base temperature $\tau_{\mathrm{h}}$ and $\tau_{\mathrm{c}}$ are determined by PRISM. A coefficient of correlation $\left(\mathrm{R}^{2}\right)$ of linear regression between energy consumption and HDDs demonstrates the reliability of the model. A good model has an $\mathrm{R}^{2}$ value close to 1.

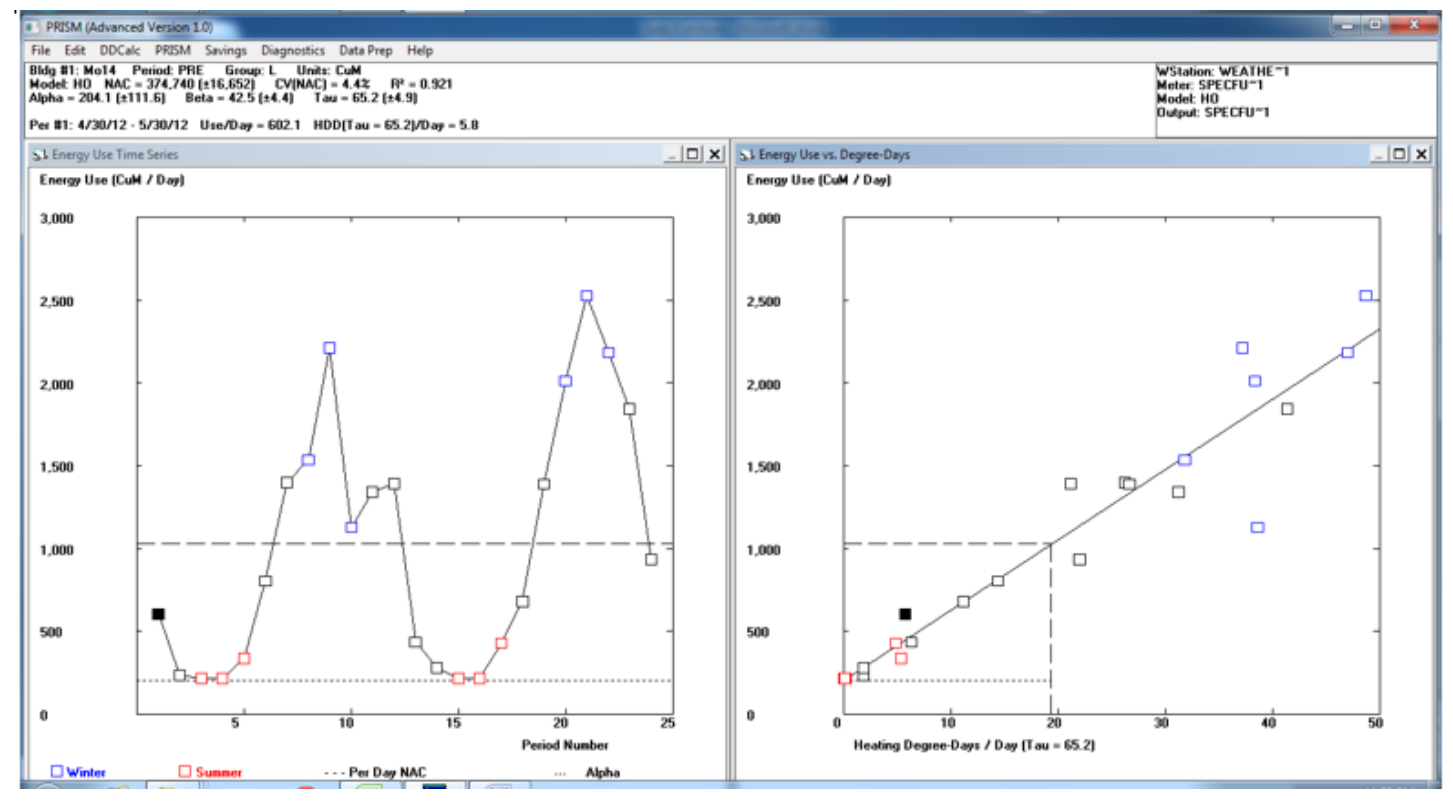

Figure 3.7: Sample analysis by PRISM and NAC value (AASPEC) 
Another approach for determining reference temperature and NAC has been performed in Excel using simple mathematical and statistical methods. HDDs are calculated by Equation 3.2. ASHRAE defines HDDs as measures of how much in degrees and for how long in days the outside air temperature was below a certain level [66].

$\mathrm{HDD}=($ reference temperature - outdoor temperature $) *$ number of days in a month

This analysis was performed several times using variable reference temperature data to determine the best $\mathrm{R}^{2}$ value. Outdoor temperatures were gathered from monthly weather data from Environment Canada. HDDs were determined for each month using Equation 3.2. A regression line was obtained by using the scatter plots in Excel where HDDs are presented on the $\mathrm{x}$-axis, while monthly consumption is presented on the $\mathrm{y}$-axis. From this scatter plot, an $\mathrm{R}^{2}$ value is found. Maximum $\mathrm{R}^{2}$ value can be determined by varying the reference temperature in HDD Equation 3.2 and in the scatter plot. This maximum $\mathrm{R}^{2}$ value and corresponding reference temperature is the base temperature of this analysis through Equation 3.2 [72]. To calculate NAC in Excel, Equation 3.3 is used, where this reference temperature is used as the base temperature. The monthly average temperature over a 31-year period was used instead of over the billing periods [73].

$\mathrm{NAC}=\mathrm{MX}+\mathrm{C}$

Where,

$\mathrm{NAC}=$ Normalized annual consumption $\left[\mathrm{m}^{3} /\right.$ year $]$

$\mathrm{M}=$ heating or cooling slope obtained in the regression line in the scatter plot 


$$
\begin{aligned}
& \mathrm{X}=\text { HDD obtained from Equation } 3.2 \text { corresponds to optimal reference temperature }\left[{ }^{\circ} \mathrm{F}\right. \text { - } \\
& \text { day }] \\
& \mathrm{C}=\text { is the fixed value on } \mathrm{Y} \text { intercept in the regression line on the scatter plot }\left[\mathrm{m}^{3}\right]
\end{aligned}
$$

Figure 3.8 presents a sample regression analysis of the industrial plants.

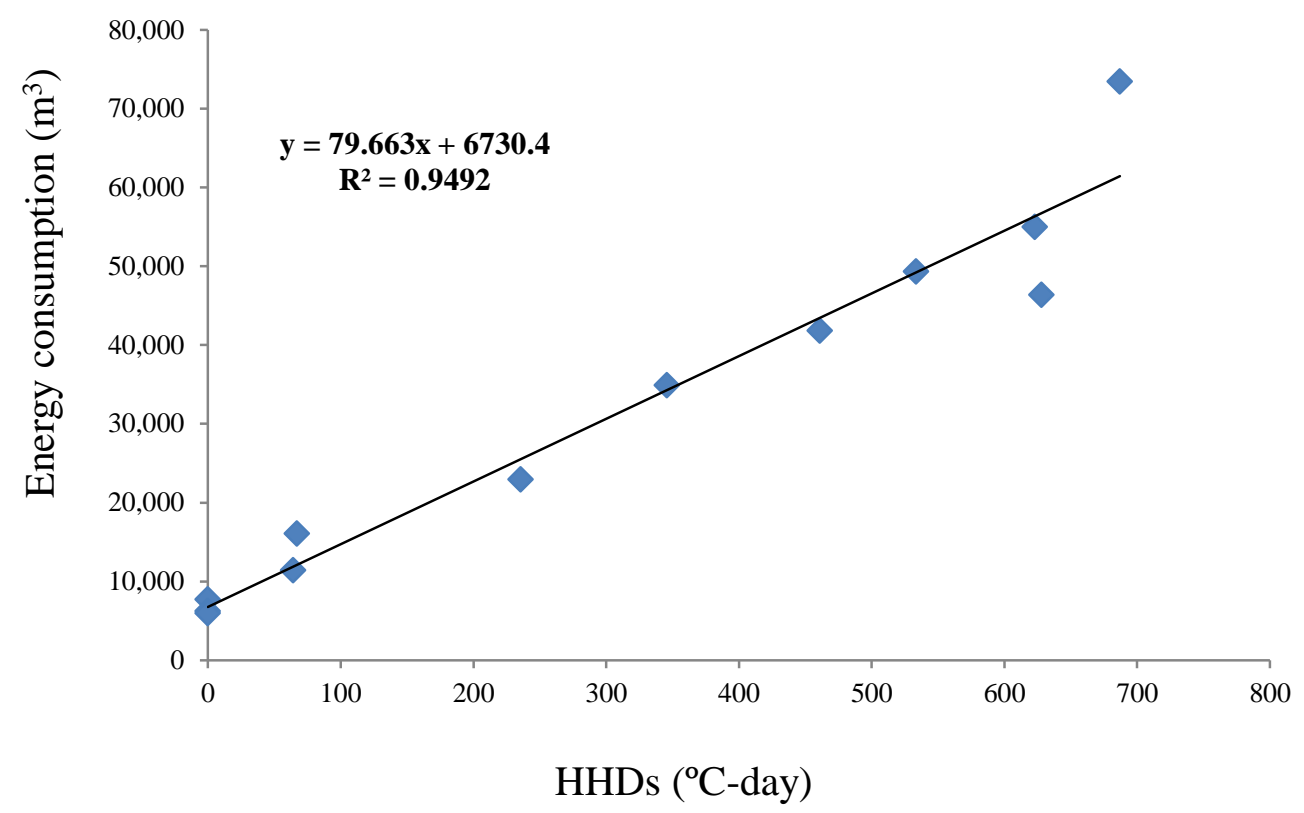

\section{Figure 3.8: Sample linear regression analysis in Excel and $\mathbf{R}^{2}$ value (AASPEC)}

The normalized energy consumption value can be estimated by Equation 3.4, which can be obtained by regression analysis.

$y=43.778 x+6394.7$

The value of " $\mathrm{y}$ ", calculated by Equation 3.4, results in a maximum $\mathrm{R}^{2}$ value obtained through varying reference temperatures. These repeated approaches of determining reference temperature and corresponding maximum $\mathrm{R}^{2}$ value are presented in Table 3.1. 
Table 3.1: $\mathbf{R}^{2}$ values based on different reference temperatures in linear regression analysis

\begin{tabular}{|c|c|c|c|c|c|c|c|c|c|c|}
\hline$R^{2}$ Value & $\frac{\sigma}{\grave{\sigma}}$ & $\underset{\hat{\sigma}}{\sigma}$ & ई̊ & 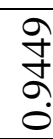 & $\begin{array}{l}\infty \\
\infty \\
0 \\
0\end{array}$ & $\begin{array}{l}\text { ta } \\
\text { aे } \\
0\end{array}$ & ণু & 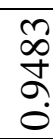 & 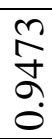 & 守 \\
\hline $\begin{array}{c}\text { Reference } \\
\text { temperature } \\
\left({ }^{\circ} \mathbf{F}\right)\end{array}$ & in & $\stackrel{\infty}{n}$ & 8 & $\widetilde{\sigma}$ & t & 6 & lo & 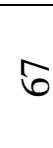 & 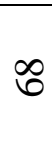 & $?$ \\
\hline $\begin{array}{c}\text { Reference } \\
\text { temperature } \\
\left({ }^{\circ} \mathrm{C}\right)\end{array}$ & $\stackrel{2}{2}$ & $\Xi$ & $\underset{\simeq}{0}$ & $\Xi$ & $\stackrel{\infty}{=}$ & $\infty$ & 2 & 2 & ণ & $\bar{\sim}$ \\
\hline
\end{tabular}

Results obtained through Excel analysis by varying reference temperature value have been plotted in another Excel graph, presented in Figure 3.9., to estimate the precise reference temperature.

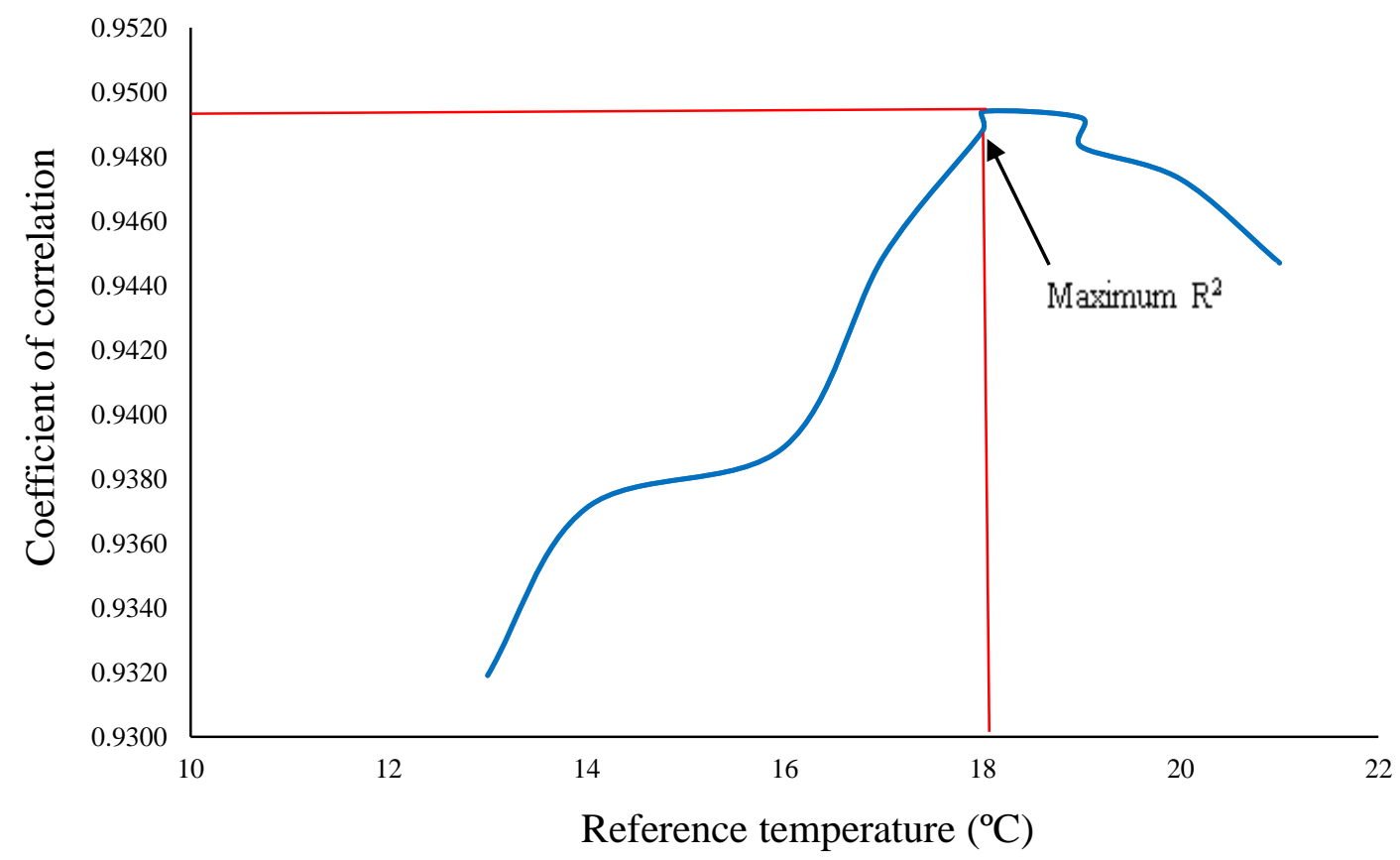

Figure 3.9: Reference temperatures $\left({ }^{\circ} \mathrm{C}\right)$ with corresponding $R^{2}$ value from Excel (AASPEC) 
Weather corrected consumption was calculated after obtaining best reference temperature by Equation 3.4. The same methodology was applied to evaluate process energy consumption, where summer months' average consumption was considered. To obtain seasonal energy consumption, process energy was subtracted from normalized energy consumption. The vertical axis (y-axis) is the average monthly weather normalized energy consumption in cubic meters of natural gas, and the horizontal axis (x-axis) is the year and month. Blue represents seasonal energy consumption, and red represents average process load in a year. June, July, and August are considered summer months, during which it is assumed no space heating is required [64, 65].

The separation of process and seasonal load is identified in Figure 3.10.

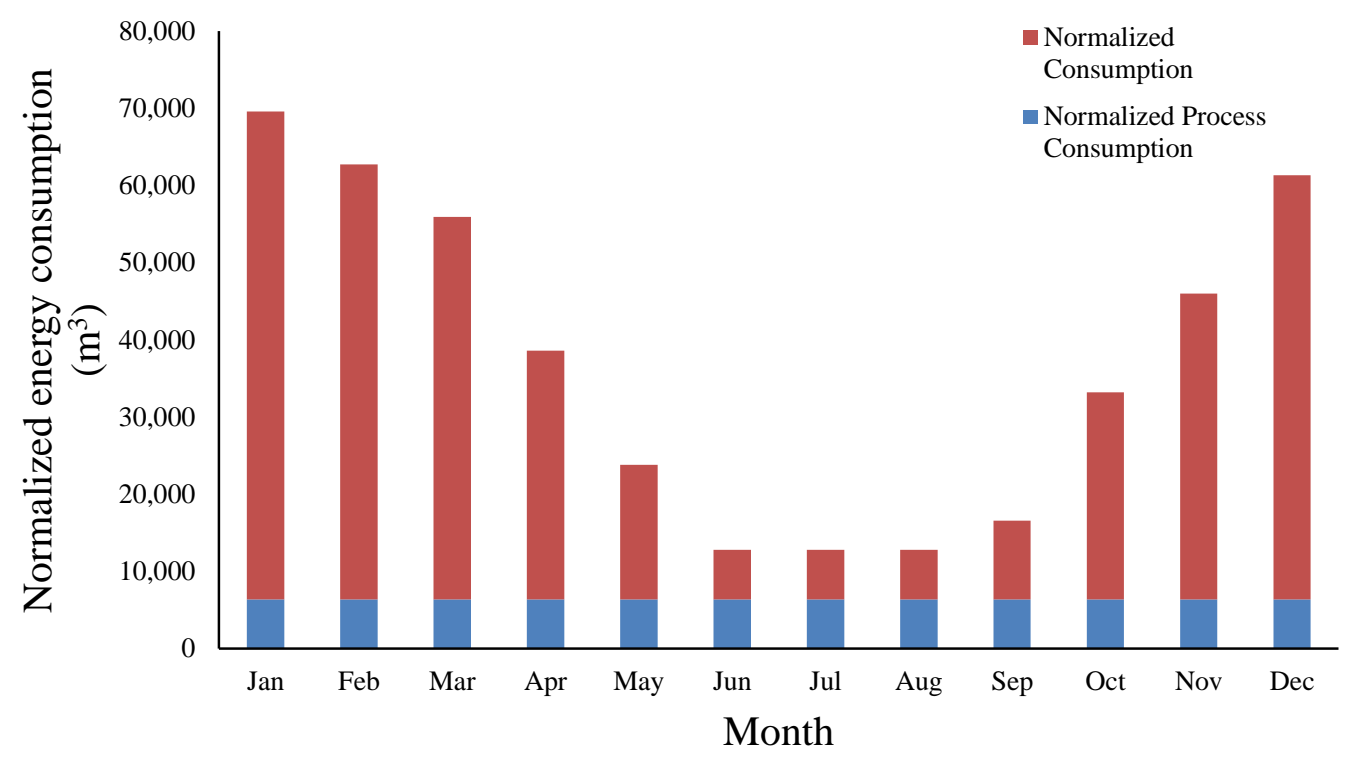

Figure 3.10: Separation of normalized process and normalized seasonal energy consumption (AASPEC) 


\subsection{Energy Balance in Ovens}

Thermodynamics in ovens is focused on energy balance [77]. This energy balance depends on the physicochemical properties of adsorption. Spontaneous adsorption is a process that can be concluded by a thermodynamic consideration called Gibbs free energy [78], which is an indicator of spontaneous chemical reaction. This chemical reaction contributes to powder coating and curing. According to the second law of thermodynamics, the heat energy produced depends on temperature and entropy [79], which are analyzed for energy balance.

Proper curing and energy application are important to powder coaters. Convection and conduction heat transfer are major modes of thermodynamic applications in ovens. Air is the medium in the convection heat transfer. Air heats the metal substrate, and the substrate heats the coating by conduction [80]. The oven must maintain the appropriate temperature for the proper duration of time to cure 100\%. Proper curing depends on the time-temperature relation. Figure 3.11 shows the time-temperature relation to curing. Time in the oven must include the time required to bring the part up to temperature.

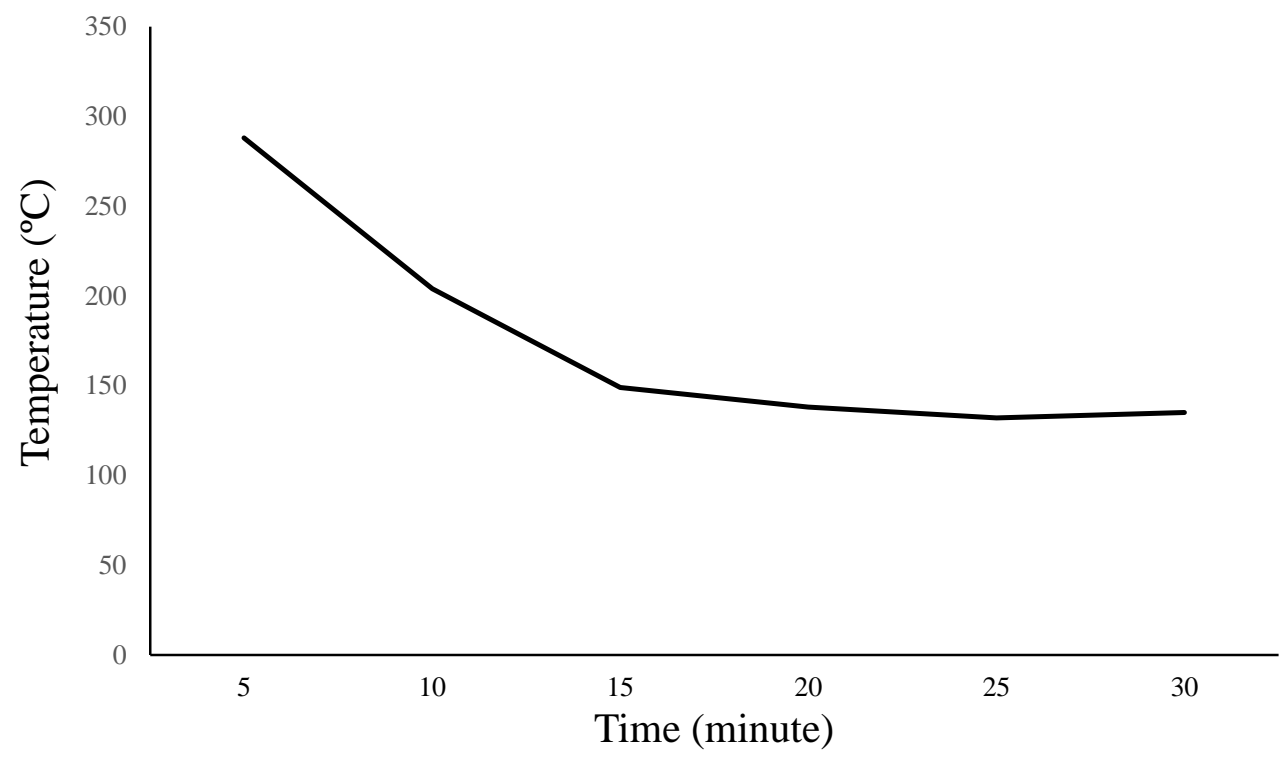

Figure 3.11: Time-temperature relation of curing [19] 
Convection gas-fired ovens are continuous flow ovens. A gas-fired convection oven is an insulated enclosure with the heat source located within the unit. Ducting maintains inlet air and exhaust flue gas. The physical shape and design of ovens depends on their usage. The burner capacity depends on the heat requirements. A burner box with an air blower inside distributes heated air inside the oven chamber.

A simple oven configuration is shown in Figure 3.12. Direct gas-fired convection is used by powder-coating companies. Energy consumption relates to three factors: (1) product loading, (2) oven-panel radiation loss, and (3) exhaust loss. There are other factors contributing to natural gas consumption. These are calculated and analyzed in the subsequent subsection.

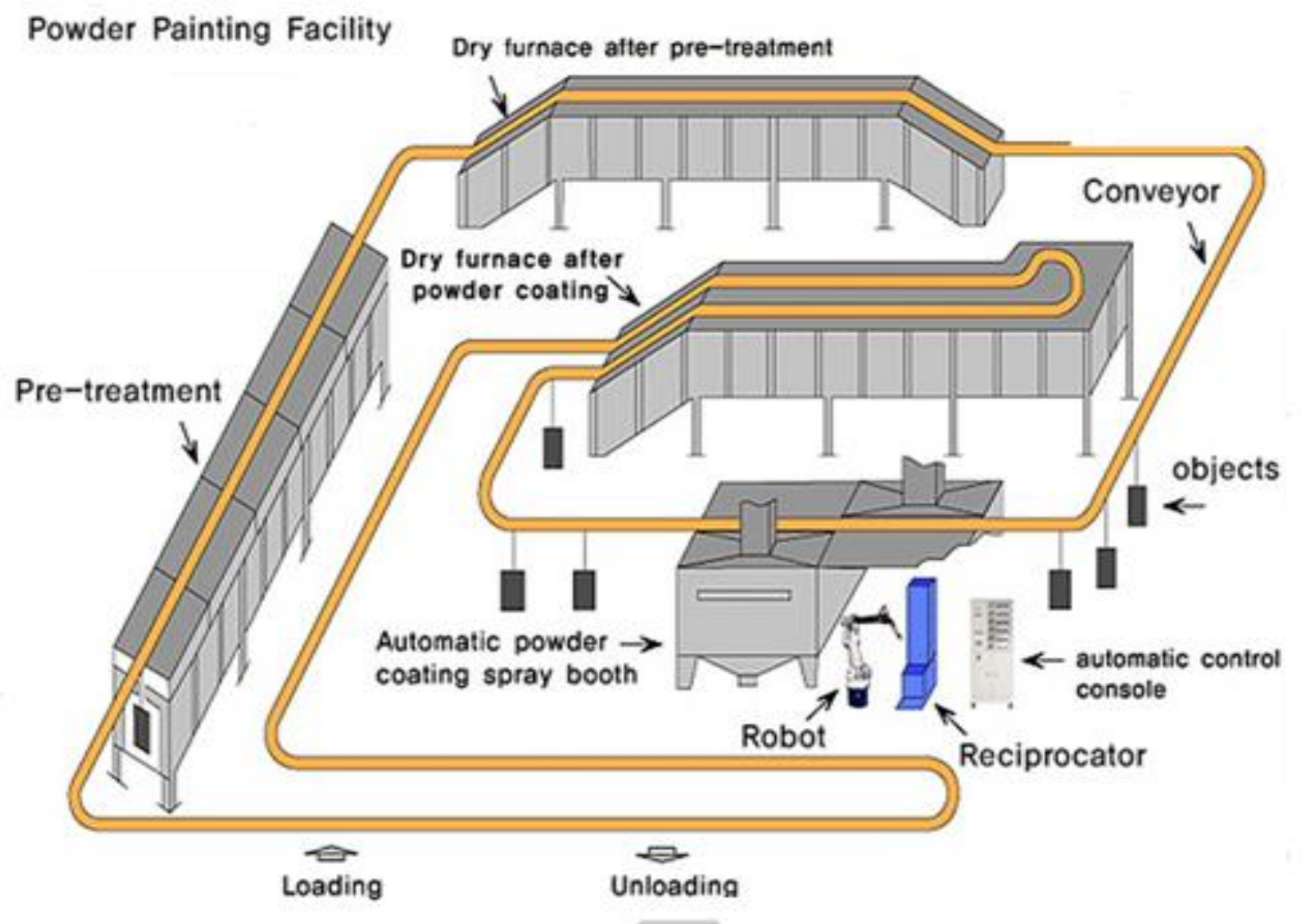

(Source: Hangzhau Color Powder Coating Equipment Co. Ltd)

Figure 3.12: Process flow of a continuous flow gas fired finishing company [81] 
Figure 3.13 shows the energy balance through a Sankey diagram

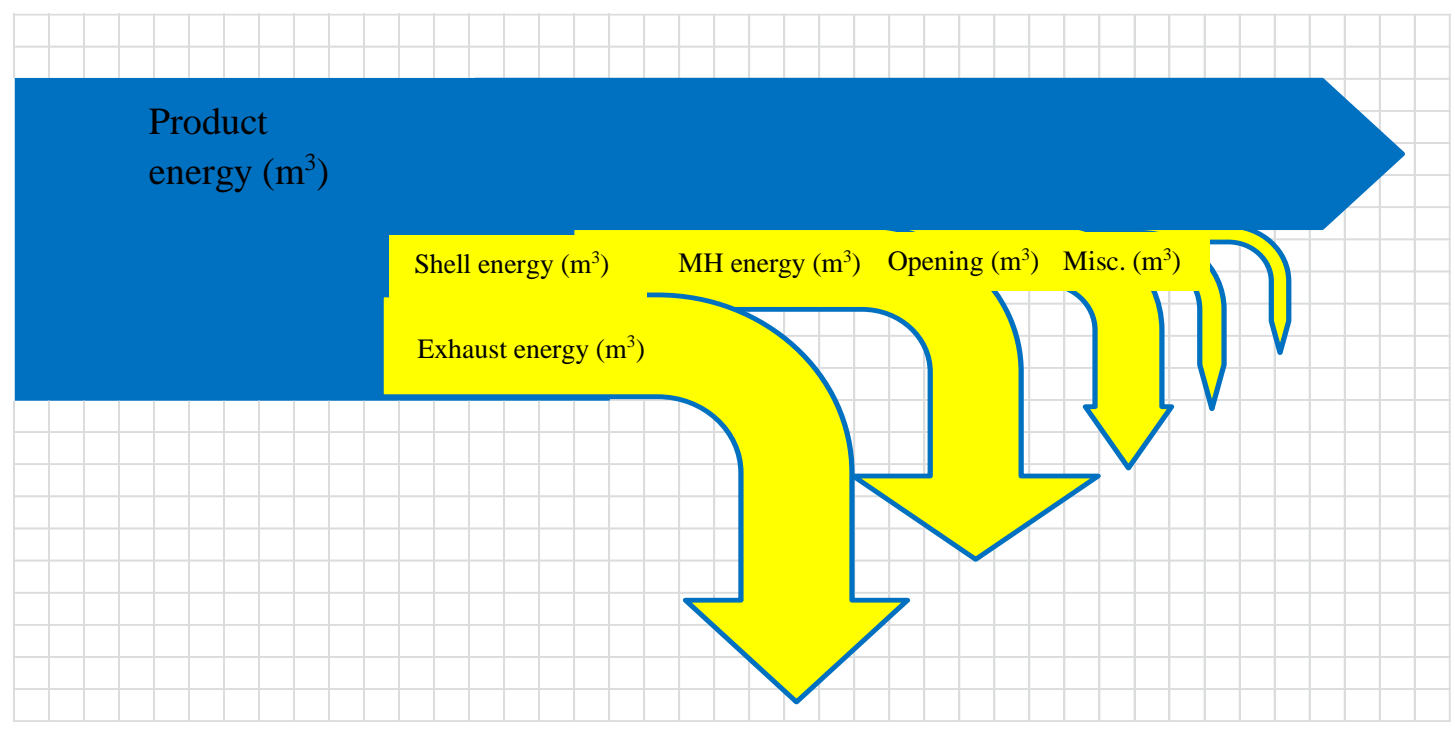

Figure 3.13: Simple process flow and energy balance of ovens (AASPEC)

\subsection{Mathematical Model and Energy Balance of Oven}

This is a mathematical model based on the heat transfer principle, a case study of a company in the GTA, and published journal literature. NFPA 86 [62] and TSSA standards [63] are considered because of safety factors and minimum protection standards. Oven energy consumption is simulated based on current production data and information gathered from discussions with the plant manager.

Data collected from plant manager,

Consumption of dry-off oven $=\left[\mathrm{m}^{3} /\right.$ year $]$

Exhaust flow rate $\left(\mathrm{Q}_{\mathrm{exh}}\right)=\mathrm{CFM}$

Dimension of dry-off oven $=\mathrm{L} \times \mathrm{W} \times \mathrm{H}\left[\mathrm{ft}^{3}\right]$

Velocity of conveyor $=\left[\mathrm{V}_{\text {line }}\right][\mathrm{fpm}]$

Average product mass and dimensions $=\left[\mathrm{m}_{\mathrm{p}}\right][\mathrm{lb}]$ 
Average product dimensions $=\left[\mathrm{ft}^{2}\right]$

Actual annual production $=[\mathrm{pcs}]$

Operation hours $=[$ shift hours per day $] \times$ [working days/week $] \times$ [working weeks per year $]=$ hours in a year

\subsubsection{Estimated Product Energy Consumption}

(a) Product throughput

$$
\begin{aligned}
\mathrm{m}_{\mathrm{fp}}[\mathrm{lb} / \text { hour }]=\mathrm{m}_{\mathrm{p}} \times \mathrm{V}_{\text {line }} \mathrm{x} 60 \times \text { Loading } / \mathrm{h}_{\mathrm{s}} \\
=[\mathrm{lb} / \text { hour }], \text { and } \\
=[\mathrm{lb} / \text { hour }] /\left[\mathrm{m}_{\mathrm{p}}\right][\mathrm{lb}]=\text { pcs product per hour }
\end{aligned}
$$

$($ Relevant parts per hook spacing $=50 \%$; hook spacing $=1 \mathrm{ft})$

Annual estimated production $=[\mathrm{pcs}] \mathrm{x}$ [hours per shift $] \mathrm{x}$ [working days in a year $]$

$$
=\text { estimated annual production }[\mathrm{pcs}]
$$

(b) Opportunity loss $=$ estimated annual production [pcs] - actual annual production [pcs] $=$ [pcs]

(c) Energy required per product $=\left[\mathrm{m}_{\mathrm{p}}\right][\mathrm{lb}] \mathrm{x}\left[\mathrm{C}_{\mathrm{p}}\right]\left[\mathrm{Btu} / \mathrm{lb}{ }^{\circ} \mathrm{F}\right] \times[\Delta \mathrm{T}]\left[{ }^{\circ} \mathrm{F}\right]$

(d) Estimated product energy required $=$ [Btu required per product] $\mathrm{x}$ [qty. of product throughput per hour $\mathrm{x}$ [number of operation hours $]=[$ Btu/year $]$

$=$ converted to $\left[\mathrm{m}^{3} /\right.$ year $]$

\subsubsection{Estimated Energy Produced by Rated Flow Capacity}

Oven efficiency $=80 \%$

Rated flow capacity, $\mathrm{q}=1,200,000[\mathrm{Btu} / \mathrm{hr}], \eta=80 \%$, 
Total estimated energy produced $=1,200,000[\mathrm{Btu} / \mathrm{hr}] \times(0.8)=1.2 \times 10^{10}$ Btu/year $=$ $1,20,000,000 \mathrm{ft}^{3} /$ year $=330,600 \mathrm{~m}^{3} /$ year

\subsubsection{Exhaust Requirement Calculation}

(a) Oven volume consists of

Oven volume $(\mathrm{A})=\mathrm{L} \times \mathrm{W} \times \mathrm{H}=\left[\mathrm{ft}^{3}\right]$

Combustion chamber volume $=\mathrm{B}\left[\mathrm{ft}^{3}\right]$

Air sealed $=\mathrm{C}\left[\mathrm{ft}^{3}\right]$

Exhaust stack $=\mathrm{D}\left[\mathrm{ft}^{3}\right]$

Total oven volume $=\mathrm{A}+\mathrm{B}+\mathrm{C}+\mathrm{D}\left[\mathrm{ft}^{3}\right]$

(b) Exhaust requirement $=$ combustion volume $\left[\mathrm{ft}^{3}\right]+$ turnover volume $\left[\mathrm{ft}^{3}\right]$

\subsubsection{Purge Rate}

Oven volume $=\mathrm{L} \times \mathrm{W} \times \mathrm{H}\left[\mathrm{ft}^{3}\right]$

NFPA 86 requires four purges before lighting $=4 \mathrm{x}$ oven volume

Existing fan design purge time $=\frac{4 \mathrm{x} \text { oven volume }}{\text { Design at constant flow rate (SCFM) }}$

If the oven kicks out at temperature, TSSA requires full purge, with the correction factor.

Correction factor $(\mathrm{CF})=\frac{T+460}{\text { Ref temp }+460}\left[\mathrm{~T}\right.$ is the oven temperature in $\left.{ }^{\circ} \mathrm{F}\right]$

Therefore, the minimum purge time should be set at operating temperature $=\mathrm{CF} \times$ calculating purge time [minute] 


\subsubsection{Operating Ventilation}

To calculate standard cubic feet per minute (SCFM) using the NEPA 86 standard which used by

Enbridge Gas Distribution Inc to their "Activity Book-Process ovens workshop" convert [MBtu/hr] to standard cubic feet per minute (SCFM)

$$
=183 \times[\mathrm{MBtu} / \mathrm{hr}]=\text { total }[\mathrm{SCFM}]
$$

Convert to actual CFM (SCFM) by CF @ $\mathrm{T}\left[{ }^{\circ} \mathrm{F}\right]=$ total $[\mathrm{SCFM}]$ x CF $=$ total $[\mathrm{ACFM}]$

Existing exhaust fan operating at $[\mathrm{SCFM}]$

Convert to ACFM by CF @ T $\left[{ }^{\circ} \mathrm{F}\right]=\mathrm{ACFM} / \mathrm{CF}=\operatorname{design}[\mathrm{ACFM}]$

Opportunity to reduce $=$ design $[\mathrm{ACFM}]-$ total $[\mathrm{ACFM}]=[\mathrm{ACFM}]_{\text {savings }}$

Heat required bringing up to $\mathrm{T}\left[{ }^{\circ} \mathrm{F}\right]$ from reference facility temperature $\left[{ }^{\circ} \mathrm{F}\right]=$ reduced $\mathrm{CFM} \mathrm{x}$ $1.08 \times \Delta \mathrm{T}=[\mathrm{Btu} / \mathrm{hr}]=$ converted to $\left[\mathrm{m}^{3} / \mathrm{year}\right]$

\subsubsection{Exhaust Volume at Constant Volume Flow Rate}

Exhaust at constant volume flow rate $=\frac{\text { oven volume }}{\text { purge time }}=[\mathrm{CFM}]$

Exhaust energy loss $=\frac{4 \times \text { oven volume }}{\text { purge time }}=[\mathrm{SCFM}]$

Energy loss due to purge $=\frac{4 \times \text { oven volume }}{\text { purge time }} \times 4 \times 1.08 \times \Delta \mathrm{T}=[\mathrm{Btu} / \mathrm{hr}]$

\subsubsection{Dwelling Time to Cure Products}

Oven dwelling time $=$ bring-up time + cure time

(Dwelling time depends on the chemical nature of the powder, concentration, particle size, and catalyst.)

$$
\mathrm{t}_{1}=\frac{t_{0}}{1.024^{\left[ \pm \Delta T\left({ }^{\circ}\right)\right]}}
$$


Where,

$$
\begin{aligned}
& \mathrm{t}_{1}=\text { new cure time after temperature change }[\mathrm{min}] \\
& \mathrm{t}_{0}=\text { cure time after temperature change }[\mathrm{min}] \\
& \Delta \mathrm{T}=\text { new temperature minus initial (base) temperature }\left[{ }^{\circ} \mathrm{F}\right]
\end{aligned}
$$

\subsubsection{Energy Loss From an Oven}

Part of input energy to oven has been loosed with material handling process. This energy loss due to continuous flow of chain and hangers which takes the product inside the oven and brings out after process.

Conveyor material handling $(\mathrm{MH})$ loss

Assume, chain weight $=\left[\mathrm{m}_{\mathrm{c}}\right][\mathrm{lb} / \mathrm{ft}]$

Assume, hook weight $=\left[\mathrm{m}_{\mathrm{h}}\right][\mathrm{lb} / \mathrm{ft}]$

Conveyor weight $=$ chain weight $\left[\mathrm{m}_{\mathrm{c}}\right][\mathrm{lb} / \mathrm{ft}]+$ hook weight $\left[\mathrm{m}_{\mathrm{h}}\right][\mathrm{lb} / \mathrm{ft}]$

Weight of material handling per hour $=[$ conveyor weight $] \times$ [conveyor speed fpm] $x$ [60]

$$
=[\mathrm{lb} / \mathrm{hr}]
$$

$\mathrm{E}_{\mathrm{mat}}$ hand $=[$ weight of material handling (chain and hook) per hour] $\mathrm{x}$ [material's specific heat capacity] $\mathrm{x} \Delta \mathrm{T}$

$$
=\mathrm{Btu} / \mathrm{hr}
$$

(This loss depends on material's specific capacity and temperature differences.) 


\subsubsection{Shell Loss}

Oven shell act as heat seal, cause to rise temperature. Thus increasing temperature is the requirement for the drying and curing process. Maximum heat seal enabling the production rate and oven efficiency.

$\mathrm{E}_{\text {shell }}[\mathrm{Btu} / \mathrm{hr}]=\mathrm{A}_{\text {shell }}\left[\mathrm{ft}^{2}\right] \mathrm{x}$ loss factor $\mathrm{x} \Delta \mathrm{T}\left[{ }^{\circ} \mathrm{F}\right]$

$$
=\text { converted to }\left[\mathrm{m}^{3} / \text { year }\right][49]
$$

\subsubsection{Opening Loss}

Continuous flow oven had two opening for process flow in and out from the oven which cause energy loss.

This is approximately $1 \%$ to $3 \%$ of the total energy $[51,53]$ :

$$
\begin{aligned}
& =[0.03] \times[\text { total oven energy consumption }]=\left[\mathrm{m}^{3} / \text { year }\right] \\
\text { Or, } \quad & =[\text { opening CFM }] \times[1.08] \times[\Delta \mathrm{T}]=[\text { Btu } / \mathrm{hr}]
\end{aligned}
$$

\subsubsection{Miscellaneous Energy Loss}

Miscellaneous energy loss can be estimated to be $1 \%$ of the total oven energy consumption [55, 57]. Miscellaneous energy loss includes radiation, fan motors etc.

\subsubsection{Total Energy Losses from Oven}

Total energy losses from oven $=[$ exhaust energy loss by oven $]+[$ shell energy loss by oven $]+$ [MH loss by oven] + [oven opening loss by oven $]+[$ miscellaneous energy loss $]$ 


\subsubsection{Actual Energy Consumed by Oven}

Actual product energy consumption $[\mathrm{Btu} / \mathrm{hr}]=$ total energy consumed by oven $[\mathrm{Btu} / \mathrm{hr}]-$ total energy losses from oven [Btu/hr]

\subsection{Productive vs. Non-productive Hours Energy Consumption}

Productive hours natural gas consumption is defined as the energy consumed in number of hours when a plant is producing [86]. Energy intensity is defined as the energy consumed over a given area $[86,87,88]$. It can be expressed in a facility as energy used per unit area. On the other hand, non-productive hours energy consumption is defined as the energy consumed when a plant is not producing. Non-productive hours include scheduled weekends, declared statutory holidays in Ontario, scheduled annual shut-down periods, and before and after work hours [89, 90, 91]. An analysis was performed on energy consumption during productive and non-productive hours to determine indices for benchmarking a plant and potential savings opportunities. The indices were natural gas consumption per unit area, process energy consumption per hour, energy intensity of a plant, and production energy index.

\subsection{Savings Calculation}

\subsubsection{Oven Savings}

There were potential savings identified in these analyses: operating ventilation savings and heat recovery savings. 


\subsubsection{Operating Ventilation Savings}

If an oven was equipped with a 1.5 -inch diameter burner, then the estimated savings were calculated:

As per NEPA $86[62,80], 1.5$ inch burner produces $1.5 \mathrm{MBtu} / \mathrm{hr}$ and converts to SCFM burner $=$ $183 \times 1.5=275$ SCFM

This SCFM burner can be converted to actual CFM by a CF.

The CF can be determined by Equation 2.10, because when an oven starts running at operating temperature, then operating ventilation CFM requirement changes to purge CFM, which is described in NEPA 86. Therefore, the NEPA 86 standard was utilized to investigate savings potential instead of constant volume ventilation.

Correction factor $=\frac{\text { oven setpoint temperature }+460}{\text { inlet temperature of oven }+460}$

Burner $(\mathrm{ACFM})_{\text {burner }}=(\mathrm{SCFM})_{\text {burner }} \mathrm{x} \mathrm{CF}$

Oven current SCFM can be converted to ACFM divided by CF.

(Oven CFM is 928, collected from specification plate during energy audit.)

Convert to ACFM by CF at operating temperature of oven $=\frac{\text { oven } \mathrm{CFM}}{\mathrm{CF}}=(\mathrm{ACFM})_{\text {oven }}$

Opportunity to reduce $=(A C F M)_{\text {burner }}-(A C F M)_{\text {oven }}=(A C F M)_{\text {savings }}$ or $(A C F M)_{\text {savings }} x$ CF

Energy required for bringing up oven setup temperature from inlet temperature $\left({ }^{0} \mathrm{~F}\right)$

$$
=(\mathrm{ACFM})_{\text {Savings }} \times 1.08 \times \Delta \mathrm{T}
$$




\subsubsection{Heat Recovery Savings}

The majority of input energy losses found in this thesis analysis were through exhaust, shell, and oven opening. Exhaust and opening loss can be reused by a heat exchanger or heat recovery wheel. A negative pressure vacuum pump controlled by a temperature sensor can be used to recover heat loss through oven opening. This excess heated air can be used to the inlet path of air flow to burner. However, shell energy loss can be reduced through improvements to the insulation. These require a major rebuild and investment of the oven. Thus, heat recovery was calculated from available sources of losses by using simple heat transfer principles.

\subsubsection{Productive vs. Non-productive Hours Savings Calculation}

It is obvious that when a plant is producing, it requires energy. However, after analyzing daily and hourly data, potential energy savings were found. This was calculated from the productive and non-productive schedules and energy consumed during the non-productive hours [89, 90 , 91]. These non-productive hours consumption savings can be achieved through proper scheduling and automation. Demand side management is the part of scheduling which can be done through proper production planning. There are different algorithm available to schedule the process. While process automation can reduce energy consumption when plant is operating.

\subsection{Simple Payback Calculation}

The payback period of an investment is defined as the number of years required to recover the capital investment through project return [93, 96, 101,]. Capital investments are strategic investments which have a long term effect aside from routine ongoing operational expenses. This 
simple payback is a popular indicator for investment decisions which is used in economic analysis. A simple approach to calculate payback period:

$\mathrm{PBP}=$ the smallest $\mathrm{m}$ such that $\sum_{\mathrm{t}=1}^{\mathrm{m}} \mathrm{A}_{\mathrm{t}} \geq \mathrm{C}_{\mathrm{o}}$

Where,

$$
\begin{aligned}
& \mathrm{PBP}=\text { Payback period [year }] \\
& \mathrm{A}_{\mathrm{t}}=\text { Sum of annual return [CAD] } \\
& \mathrm{C}_{\mathrm{o}}=\text { Capital investment }[\mathrm{CAD}]
\end{aligned}
$$

It is estimated that if PBP is less than or equal to a pre-determined time then the investment is attractive. However, this type of payback calculation ignores the time value of money. 


\section{Chapter 4: Analysis of SMEs Energy Consumption and Potential Savings Opportunities}

\subsection{Energy Consumption by Ovens and Percentage of Total Process Consumption}

This study analyzed the process energy consumption of eleven SMEs, which are involved in the food and finishing process industries, within the GTA. Specifically, two of the eleven companies are bakeries and use bake ovens, while the nine remaining SMEs are finishing process companies which use two types of ovens: Dry-off and Cure ovens. The acronym of the company followed by the letters B, D, and C, which refer to bake oven, dry-off oven, and cure oven, respectively.

Table 4.1 column 1 shows the type of oven, column 2 shows the type of company, column 3 shows the plant area, column 4 shows the normalized annual energy consumption, column 5 shows the normalized process energy consumption, column 6 shows the normalized seasonal energy consumption, column 7 shows the total consumption by each type of oven, and column 8 the percentage consumption of energy of normalized process energy consumption.

The study observed that bakeries have major process consumption wherein their ovens consumed $47 \%$ and $73 \%$ of total process energy respectively. The remaining process energy was consumed for other processes before and after baking. In the same study, each type of ovens from the finishing process industries consumed $26 \%$ to $68 \%$ of normalized process energy. Finishing process industries regularly employed processes of powder coating and curing which require higher temperatures and longer operating times than bake ovens. Maintaining the internal thermal condition of the oven and removing moisture from parts coated from direct fired powder coating and curing require thermal energy from burning a mixture of natural gas and oxygen. 
Table 4.1: Summary of energy balance of audited companies

\begin{tabular}{|c|c|c|c|c|c|c|c|c|}
\hline 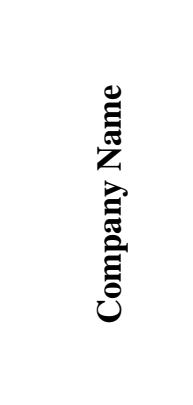 & 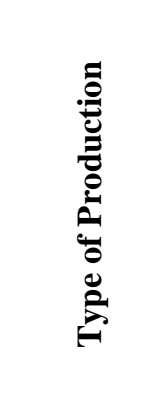 & 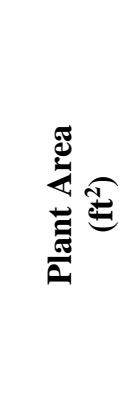 & 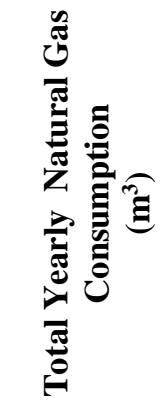 & 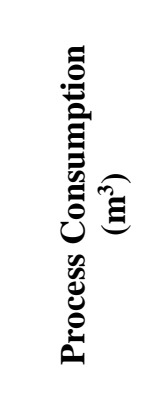 & 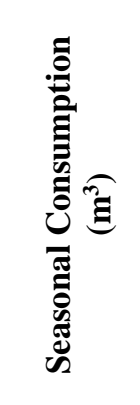 & 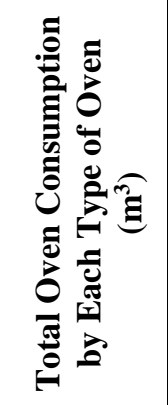 & 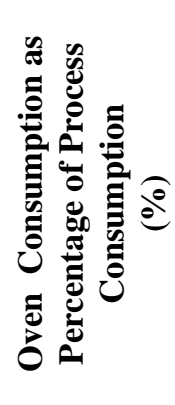 & 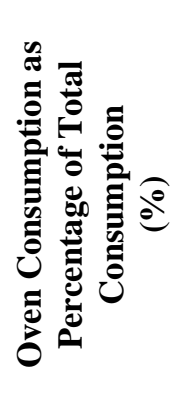 \\
\hline AAGF-B & Food & 188,290 & $3,372,327$ & $2,781,456$ & 590,871 & $1,300,000$ & 47 & 39 \\
\hline AASN-B & Food & 188,045 & 546,832 & 483,924 & 62,908 & 355,280 & 73 & 65 \\
\hline AAAL-D & \multirow{2}{*}{ Finishing } & \multirow{2}{*}{66,142} & \multirow{2}{*}{584,907} & 465,608 & 119,880 & 120,184 & 26 & 21 \\
\hline AAAL-C & & & & 465,608 & 119,880 & 150,275 & 32 & 26 \\
\hline AABN-D & \multirow{2}{*}{ Finishing } & \multirow{2}{*}{98,370} & \multirow{2}{*}{363,976} & 251,124 & 112,852 & 119,317 & 48 & 33 \\
\hline AABN-C & & & & 251,124 & 112,852 & 171,134 & 68 & 47 \\
\hline AACF-D & \multirow{2}{*}{ Finishing } & \multirow{2}{*}{46,786} & \multirow{2}{*}{437,383} & 403,590 & 34,185 & 108,000 & 27 & 25 \\
\hline AACF-C & & & & 403,590 & 34,185 & 163,000 & 40 & 37 \\
\hline AAMP-D & \multirow{2}{*}{ Finishing } & \multirow{2}{*}{67,604} & \multirow{2}{*}{514,025} & 345,588 & 168,437 & 129,000 & 37 & 25 \\
\hline AAMP-C & & & & 345,588 & 168,437 & 168,509 & 49 & 33 \\
\hline AAACT-D & \multirow{2}{*}{ Finishing } & \multirow{2}{*}{10,327} & \multirow{2}{*}{161,682} & 134,316 & 27,684 & 42,565 & 32 & 26 \\
\hline AAMP-C & & & & 134,316 & 27,684 & 57,809 & 43 & 36 \\
\hline AASPEC-D & \multirow{2}{*}{ Finishing } & \multirow{2}{*}{60,713} & \multirow{2}{*}{369,364} & 76,736 & 292,628 & 39,500 & 51 & 11 \\
\hline AASPEC-D & & & & 76,736 & 292,628 & 37,000 & 48 & 10 \\
\hline AAWIL-D & \multirow{2}{*}{ Finishing } & \multirow{2}{*}{110,270} & \multirow{2}{*}{298,809} & 187,836 & 110,973 & 68,243 & 36 & 23 \\
\hline AAWIL-C & & & & 187,836 & 110,973 & 100,394 & 53 & 34 \\
\hline D-78-D & \multirow{2}{*}{ Finishing } & \multirow{2}{*}{230,453} & \multirow{2}{*}{951,907} & 190,896 & 761,011 & 58,714 & 31 & 6 \\
\hline D-78-C & & & & 190,896 & 761,011 & 90,361 & 47 & 9 \\
\hline D-225-D & \multirow{2}{*}{ Finishing } & \multirow{2}{*}{213,668} & \multirow{2}{*}{$1,306,121$} & 448,308 & 857,813 & 121,134 & 27 & 9 \\
\hline D-225-C & & & & 448,308 & 857,813 & 140,804 & 31 & 11 \\
\hline
\end{tabular}

\subsection{Energy Intensity of an Oven}

The International Energy Agency (IEA) defines "energy intensity as the amount of energy consumed per activity or output for subsectors and end uses" [85]. An oven processing the same amount of product with less energy consumption can be considered more efficient. Energy intensity in terms of volume of oven is calculated by dividing the oven's total energy consumption by the volume of the oven and, likewise, energy intensity in terms of area of oven is calculated by dividing the oven's total energy consumption by the area of oven envelope. 
Columns 5 and 6 in Table 4.2 show the energy intensity of different ovens of the companies studied and, therefore, provides an idea of which ovens are the most and least efficient. Table 4.2 shows that among the audited companies AAWIL's cure oven is the most energy efficient oven by energy intensity in terms of volume and AAMP's dry-off oven is the least efficient oven in the same category. On the other hand, AASPEC's cure oven is the most efficient oven by energy intensity in terms of area.

Table 4.2: Energy intensity of ovens

\begin{tabular}{|c|c|c|c|c|c|}
\hline 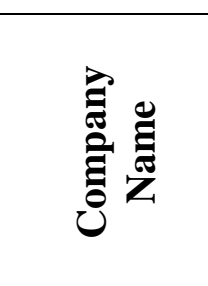 & 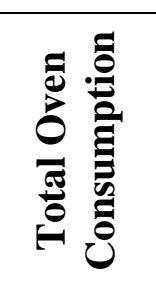 & 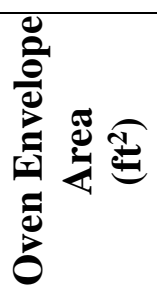 & 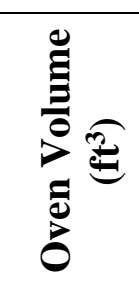 & 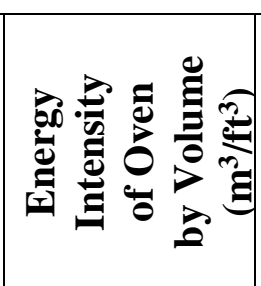 & 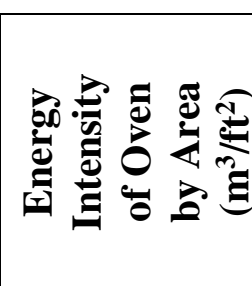 \\
\hline AAGF-B & 325,000 & 5,044 & 13,520 & 24 & 64 \\
\hline AASN-B & 355,280 & 4,640 & 12,000 & 30 & 77 \\
\hline AAAL-D & 120,184 & 4,200 & 10,000 & 12 & 29 \\
\hline AAAL-C & 150,275 & 5,080 & 13,200 & 11 & 30 \\
\hline AABN-D & 119,317 & 2,680 & 4,800 & 25 & 45 \\
\hline AABN-C & 171,134 & 3,760 & 9,600 & 18 & 46 \\
\hline AACF-D & 108,000 & 1,960 & 4,000 & 27 & 55 \\
\hline AACF-C & 163,000 & 2,880 & 7,200 & 23 & 57 \\
\hline AAMP-D & 129,000 & 2,040 & 3,600 & 36 & 63 \\
\hline AAMP-C & 168,509 & 2,600 & 6,000 & 28 & 65 \\
\hline AAACT-D & 42,565 & 1,400 & 2,400 & 18 & 30 \\
\hline AAMP-C & 57,809 & 2,000 & 4,800 & 12 & 29 \\
\hline AASPEC-D & 39,500 & 2,360 & 4,200 & 9 & 17 \\
\hline AASPEC-C & 37,000 & 2,320 & 4,800 & 8 & 16 \\
\hline AAWIL-D & 68,243 & 3,576 & 6,480 & 11 & 19 \\
\hline AAWIL-C & 100,394 & 5,520 & 14,400 & 7 & 18 \\
\hline D-78-D & 58,714 & 2,808 & 5,040 & 12 & 21 \\
\hline D-78-C & 90,361 & 3,936 & 10,080 & 9 & 23 \\
\hline D-225-D & 121,134 & 4,032 & 9,216 & 13 & 30 \\
\hline D-225-C & 140,804 & 5,760 & 18,432 & 8 & 24 \\
\hline
\end{tabular}


Table 4.3 shows oven ranking by energy intensity in terms of volume. The audited companies were categorized according to the energy intensity of their ovens. These categories are, highperforming, regular-performing, and low-performing companies. Table 4.3 shows that energy intensities in terms of volume ranging from 7-10 were classified as high-performing companies, energy intensities ranging from 10-20 were regular-performing companies, and energy intensities ranging from 20-36 low-performing companies. This benchmarking done based on eleven companies data where twenty ovens were considered. Result of this benchmarking would be more reasonable if this analysis performed by more data set (approximately 50 companies' data)

Table 4.3: Oven ranking based on energy intensity by oven volume

\begin{tabular}{|c|c|c|c|}
\hline \multirow[t]{2}{*}{$\begin{array}{l}\text { Company Name } \\
\text { and Oven Type }\end{array}$} & Oven Volume & $\begin{array}{c}\text { Energy } \\
\text { Intensity by } \\
\text { Oven Volume }\end{array}$ & \multirow[t]{2}{*}{$\begin{array}{c}\text { Benchmarking } \\
\text { Based on Oven } \\
\text { Energy } \\
\text { Intensity }\end{array}$} \\
\hline & $\left(\mathbf{m}^{3}\right)$ & $\left(\mathrm{m}^{3} / \mathbf{f} \mathbf{t}^{3}\right)$ & \\
\hline AAWIL-C & 14,400 & 7 & \multirow{5}{*}{$\begin{array}{c}\text { High } \\
\text { performing } \\
\text { industrial plants }\end{array}$} \\
\hline D-225-C & 18,432 & 8 & \\
\hline AASPEC-C & 4,800 & 8 & \\
\hline D-78-C & 10,080 & 9 & \\
\hline AASPEC-D & 4,200 & 9 & \\
\hline AAWIL-D & 6,480 & 11 & \multirow{8}{*}{$\begin{array}{c}\text { Regular } \\
\text { performing } \\
\text { industrial plants }\end{array}$} \\
\hline AAAL-D & 13,200 & 11 & \\
\hline D-78-D & 5,040 & 12 & \\
\hline AAAL-C & 10,000 & 12 & \\
\hline AAACT-C & 4,800 & 12 & \\
\hline D-225-D & 9,216 & 13 & \\
\hline AAACT-D & 2,400 & 18 & \\
\hline AABN-C & 9,600 & 18 & \\
\hline AACF-C & 7,200 & 23 & \multirow{7}{*}{$\begin{array}{l}\text { Low performing } \\
\text { industrial plants }\end{array}$} \\
\hline AAGF-B & 13,520 & 24 & \\
\hline AABN-D & 4,800 & 25 & \\
\hline AACF-D & 4,000 & 27 & \\
\hline AAMP-C & 6,000 & 28 & \\
\hline AASN-B & 12,000 & 30 & \\
\hline AAMP-D & 3,600 & 36 & \\
\hline
\end{tabular}


Figure 4.1 provides a comparative analysis of the energy intensity of different ovens used by the audited companies. The $\mathrm{X}$-axis shows the acronym of the company followed by the letters $\mathrm{B}, \mathrm{D}$, and $\mathrm{C}$, which refer to bake oven, dry-off oven, and cure oven, respectively. The Y-axis shows the energy intensity. The most efficient oven is AAWIL-C while the least efficient is AAMP-D.

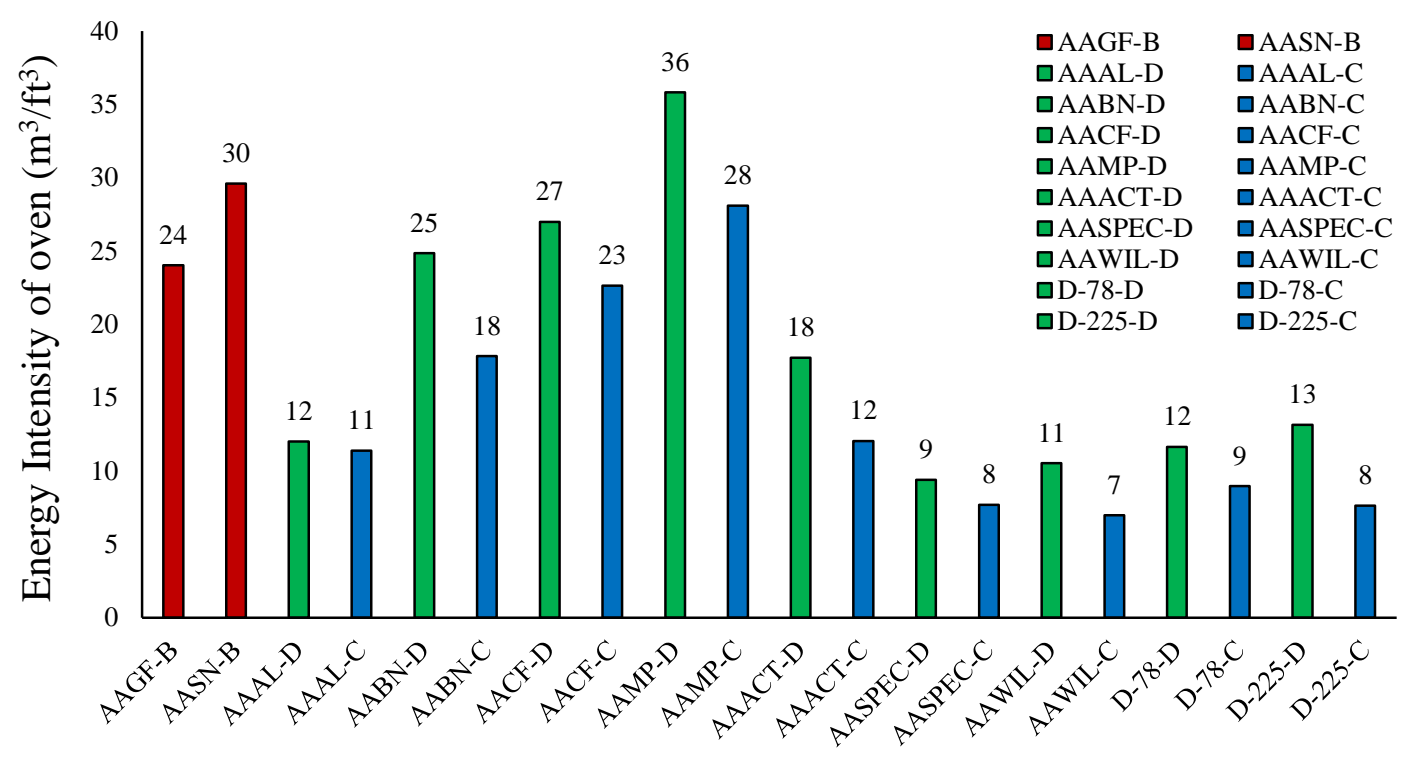

Type of Oven

Figure 4.1: Energy intensity of oven

\subsection{Energy Intensity Analysis with Different Oven Parameters}

"Oven energy intensity" refers to the energy consumption in a unit volume (energy intensity by volume), or per unit area (energy intensity by area of oven envelope) [85]. Energy intensity with different parameters was analyzed to identify the potential factor/factors on which energy intensity depends. The considered parameters are; oven volume, oven envelope area, and temperature difference. Data for these parameters were collected during energy audit. 
Figure 4.2 displays energy intensity and oven volume. Energy intensity decreases when the oven volume increases. Low $\mathrm{R}^{2}$ value shows that there is no significant correlation between energy intensity and oven volume. AAMP-D shows higher energy intensive oven while AAWIL-C is the lowest energy intensive.

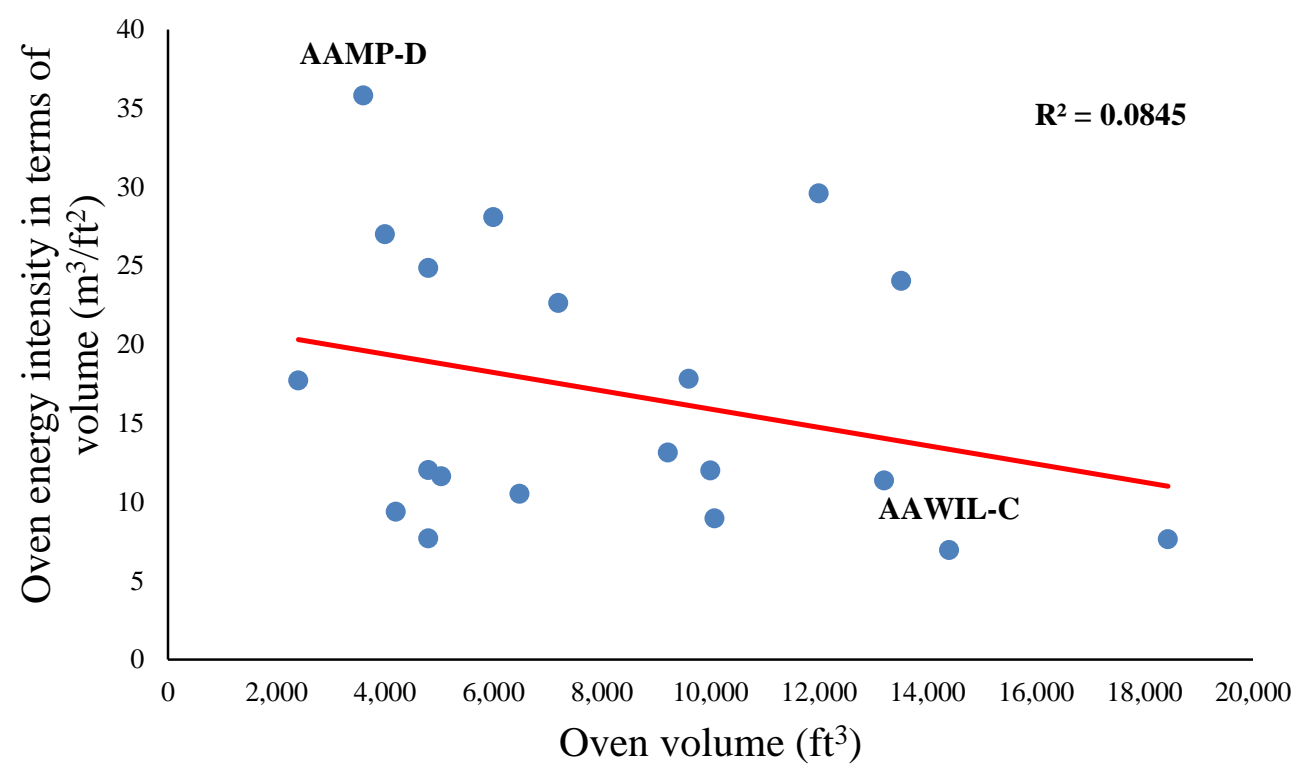

Figure 4.2: Energy intensity in terms of volume vs. oven volume

Figure 4.3 displays the oven envelope area, on the X-axis. Oven energy intensity in terms of volume is plotted on the Y-axis. A statistical analysis shows that the correlation between these parameters is not very strong. Graph shows that energy intensity decreases with the increase of oven envelope area. AAMP-D shows the highest energy intensive oven while AAWIL-C is the lowest energy intensive among the others.

The graph shows that points are widely dispersed in a scattered plot from the trend line because temperature differences and operating hours are not same for each type of oven and facility. On the other hand, improper burning affects energy intensity. 


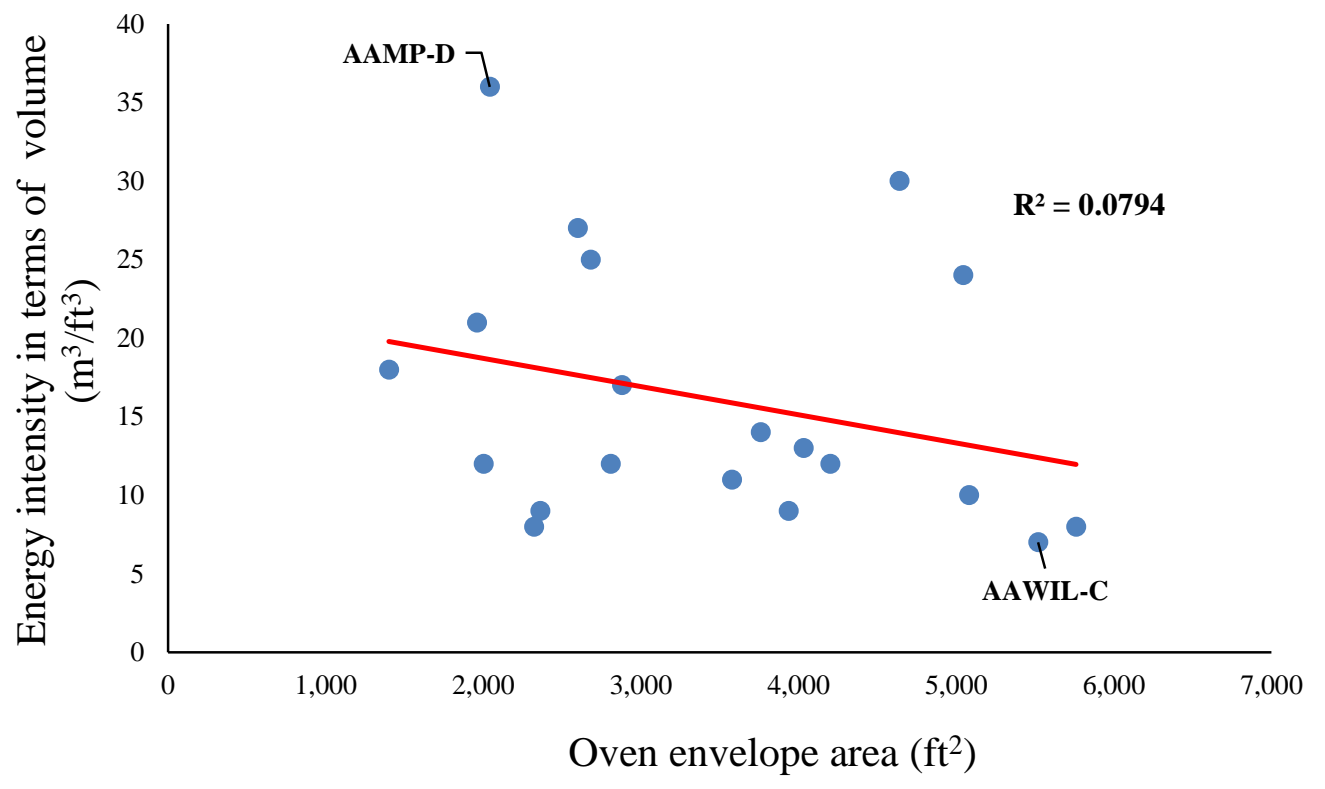

Figure 4.3: Energy intensity in terms of volume vs. oven envelope area

Figure 4.4 displays the oven envelope area, on the X-axis. Oven energy intensity in terms of area is plotted on the Y-axis. A statistical analysis shows that there is no significant relationship between two parameters. The graph shows that an increase in the oven envelope area results in a very insignificant decrease in energy intensity. Analysis shows that AASN-B is the highest energy intensive oven while AASPEC-D is the lowest.

Only a few points are dispersed in the scattered plot from the trend line due to of dissimilar temperature differences, operating hours, and production types. Improper combustion is another cause of higher energy intensity. 


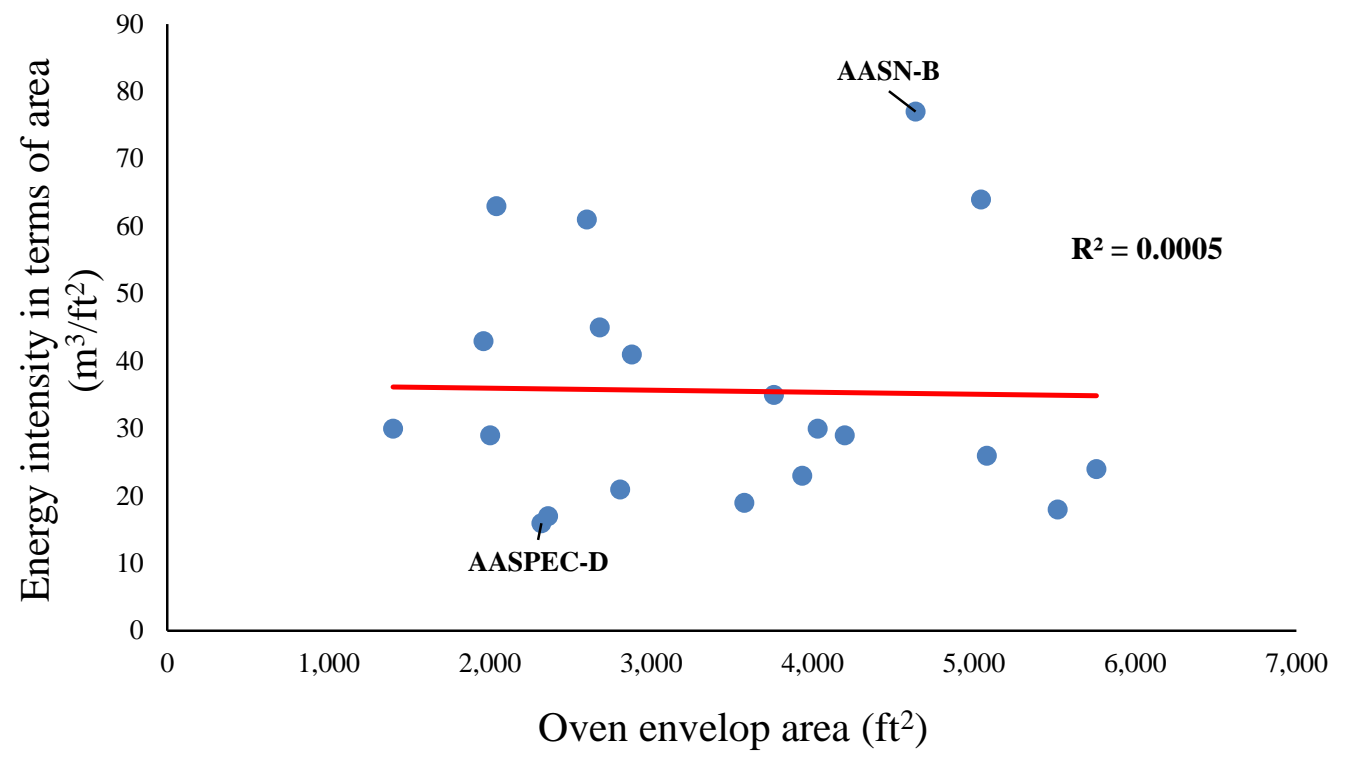

Figure 4.4: Energy intensity in terms of area vs. oven envelope area

Figure 4.5 displays oven operating hour times, on the $\mathrm{X}$-axis while the oven energy intensity in terms of area is plotted on the Y-axis. Analysis shows that the correlation between these parameters is very strong. Oven operating hour affect energy intensity. Study shows that AASN$\mathrm{B}$ is the highest energy intensive and AASPEC-C is the lowest among the ovens.

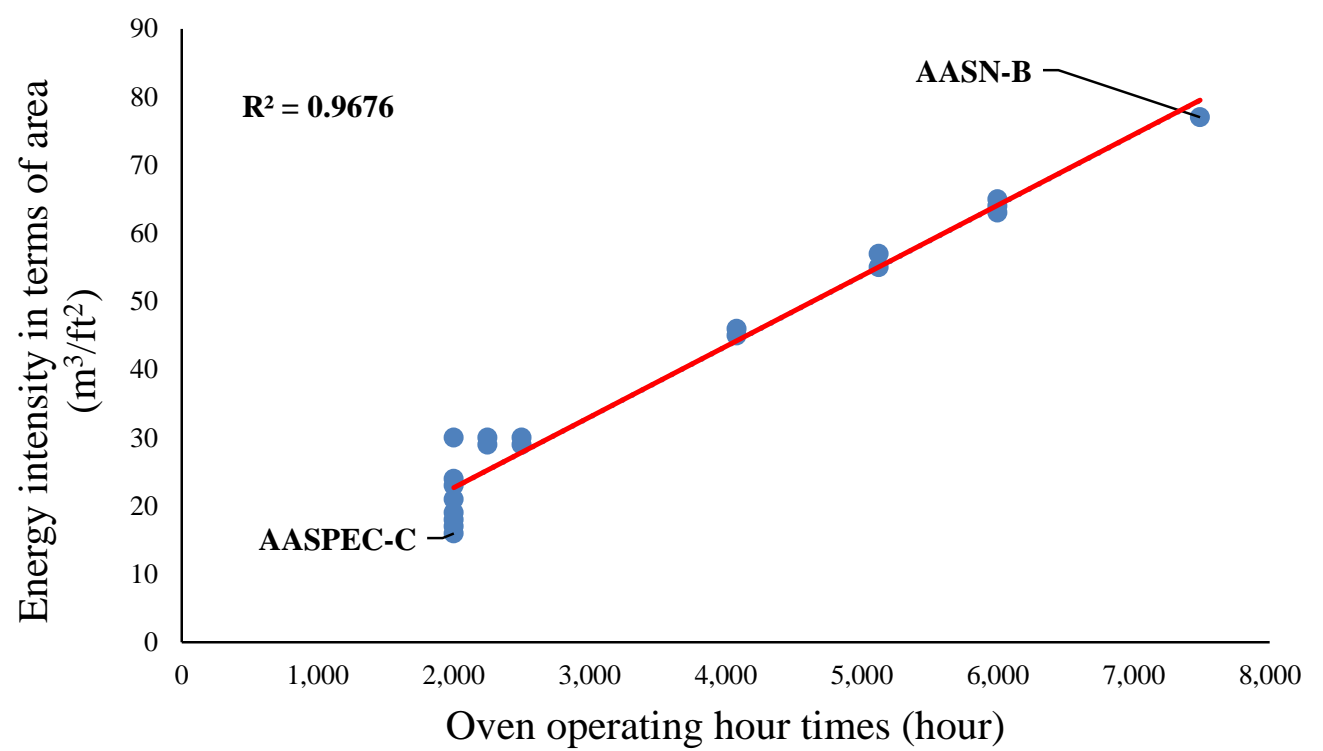

Figure 4.5: Energy intensity in terms of area vs. oven operating hour 
On the X-axis of Figure 4.6, the differences in operating temperatures of ovens are displayed. Oven energy intensity in terms of volume is plotted on the $\mathrm{Y}$-axis. Low $\mathrm{R}^{2}$ shows that the correlation between energy intensity in terms of volume and temperature difference is not strong. Energy intensity in terms of volume increased with operating temperature differences. Result of this analysis shows that AAMP-D is the highest energy intensive and AAWIL-C is the lowest energy intensive ovens.

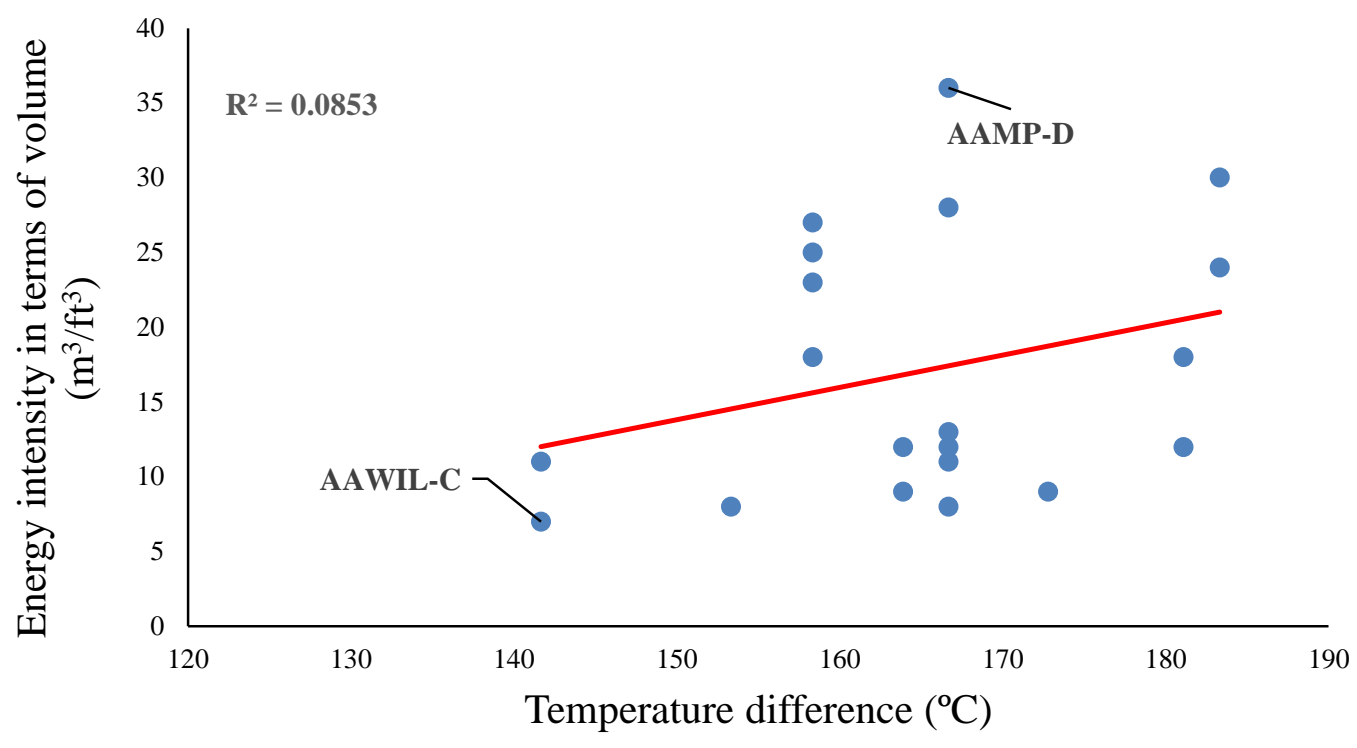

Figure 4.6: Energy intensity in terms of volume vs. temperature difference

On the X-axis of Figure 4.7, the differences of operating temperature of ovens are displayed. Oven energy intensity in terms of area is plotted on the Y-axis. Analysis shows the correlation between energy intensity by area and temperature is not strong. 


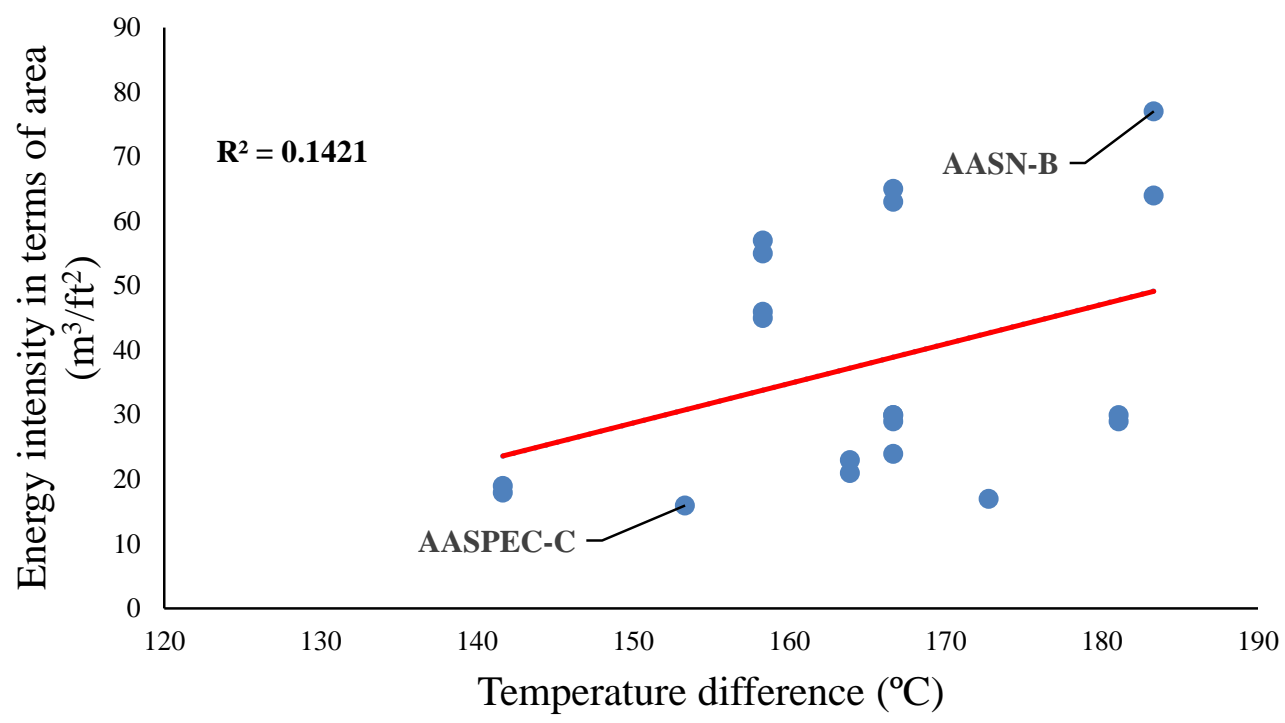

Figure 4.7: Energy intensity in terms of area vs. temperature difference

In Figures 4.2 to Figure 4.7, oven energy intensities are plotted on the Y-axes while other parameters are plotted on the X-axes. It is found that intensity does not have strong relation with oven volume, oven envelope area, and operating temperature difference, while energy intensity increases with operating temperature difference and oven volume. This means that energy intensity is affected by other factors such as exhaust loss, shell loss, radiation loss, and loss with product etc.

Points are scattered in the plot area because the ovens are not all the same size, and don't all have the same operating hours or burner capacity. Processing parts inside the oven aren't the same size and shape, which causes different energy consumption. Therefore, few of the points stray from the trend. However, the graph shows that with the increase of temperature differences, energy consumption also increases. 


\subsection{Energy Consumption Analysis with oven Volume, Area and Operation Hours}

Table 4.4 displays the oven energy consumption and $\mathrm{ft}^{2} \mathrm{hr}$ and $\mathrm{ft}^{3} \mathrm{hr}$. Column 2 displays the energy consumption of an oven while Column 6 and 7 shows oven area multiply by operation hours and oven volume multiply by operation hours.

Table 4.4: Oven consumption and oven area, and oven volume multiply hour of operation

\begin{tabular}{|c|c|c|c|c|c|c|}
\hline $\begin{array}{c}\text { Company } \\
\text { Name }\end{array}$ & $\begin{array}{c}\text { Total Oven } \\
\text { Consumption }\end{array}$ & $\begin{array}{c}\text { Oven } \\
\text { Envelope } \\
\text { Area }\end{array}$ & $\begin{array}{c}\text { Oven } \\
\text { Volume }\end{array}$ & $\begin{array}{c}\text { Workings } \\
\text { Hours in a } \\
\text { Year }\end{array}$ & $\begin{array}{c}\text { Oven Area } \\
\text { and } \\
\text { Operation } \\
\text { Hour }\end{array}$ & $\begin{array}{c}\text { Oven Volume } \\
\text { and Operation } \\
\text { Hour }\end{array}$ \\
\cline { 2 - 6 } & $\mathbf{( m}^{\mathbf{3} / \mathbf{y e a r})}$ & $\left.\mathbf{f f t}^{\mathbf{2}}\right)$ & $\mathbf{f f t}^{\mathbf{3}} \mathbf{)}$ & $\mathbf{( h r )}$ & $\mathbf{f t}^{\mathbf{2}} \mathbf{h r}$ & $\mathbf{f t}^{\mathbf{3}} \mathbf{h r}$ \\
\hline AAGF-B & 325,000 & 5,044 & 13,520 & 6,000 & $30,264,000$ & $81,120,000$ \\
\hline AASN-B & 355,280 & 4,640 & 12,000 & 7,488 & $34,744,320$ & $89,856,000$ \\
\hline AAAL-D & 120,184 & 4,200 & 10,000 & 2,500 & $10,500,000$ & $25,000,000$ \\
\hline AAAL-C & 150,275 & 5,080 & 13,200 & 2,500 & $12,700,000$ & $33,000,000$ \\
\hline AABN-D & 119,317 & 2,680 & 4,800 & 4,080 & $10,934,400$ & $19,584,000$ \\
\hline AABN-C & 171,134 & 3,760 & 9,600 & 4,080 & $15,340,800$ & $39,168,000$ \\
\hline AACF-D & 108,000 & 1,960 & 4,000 & 5,125 & $10,045,000$ & $20,500,000$ \\
\hline AACF-C & 163,000 & 2,880 & 7,200 & 5,125 & $14,760,000$ & $36,900,000$ \\
\hline AAMP-D & 129,000 & 2,040 & 3,600 & 6,000 & $12,240,000$ & $21,600,000$ \\
\hline AAMP-C & 168,509 & 2,600 & 6,000 & 6,000 & $15,600,000$ & $36,000,000$ \\
\hline AAACT-D & 42,565 & 1,400 & 2,400 & 2,250 & $3,150,000$ & $5,400,000$ \\
\hline AAMP-C & 57,809 & 2,000 & 4,800 & 2,250 & $4,500,000$ & $10,800,000$ \\
\hline AASPEC-D & 39,500 & 2,360 & 4,200 & 2,000 & $4,720,000$ & $8,400,000$ \\
\hline AASPEC-C & 37,000 & 2,320 & 4,800 & 2,000 & $4,640,000$ & $9,600,000$ \\
\hline AAWIL-D & 68,243 & 3,576 & 6,480 & 2,000 & $7,152,000$ & $12,960,000$ \\
\hline AAWIL-C & 100,394 & 5,520 & 14,400 & 2,000 & $11,040,000$ & $28,800,000$ \\
\hline D-78-D & 58,714 & 2,808 & 5,040 & 2,000 & $5,616,000$ & $10,080,000$ \\
\hline D-78-C & 90,361 & 3,936 & 10,080 & 2,000 & $7,872,000$ & $20,160,000$ \\
\hline D-225-D & 121,134 & 4,032 & 9,216 & 2,000 & $8,064,000$ & $18,432,000$ \\
\hline D-225-C & 140,804 & 5,760 & 18,432 & 2,000 & $11,520,000$ & $36,864,000$ \\
\hline & & & & & & \\
\hline
\end{tabular}

On $\mathrm{Y}$ axis of Figure 4.8, the oven operating hour multiply with oven area are plotted and energy consumption of ovens are plotted on the $\mathrm{X}$ axis. The value of $\mathrm{R}^{2} 0.9794$ shows a strong corelation observed between these two variables. Therefore it can be estimated that oven consumption increases with the increases of oven operating hours and oven area. 


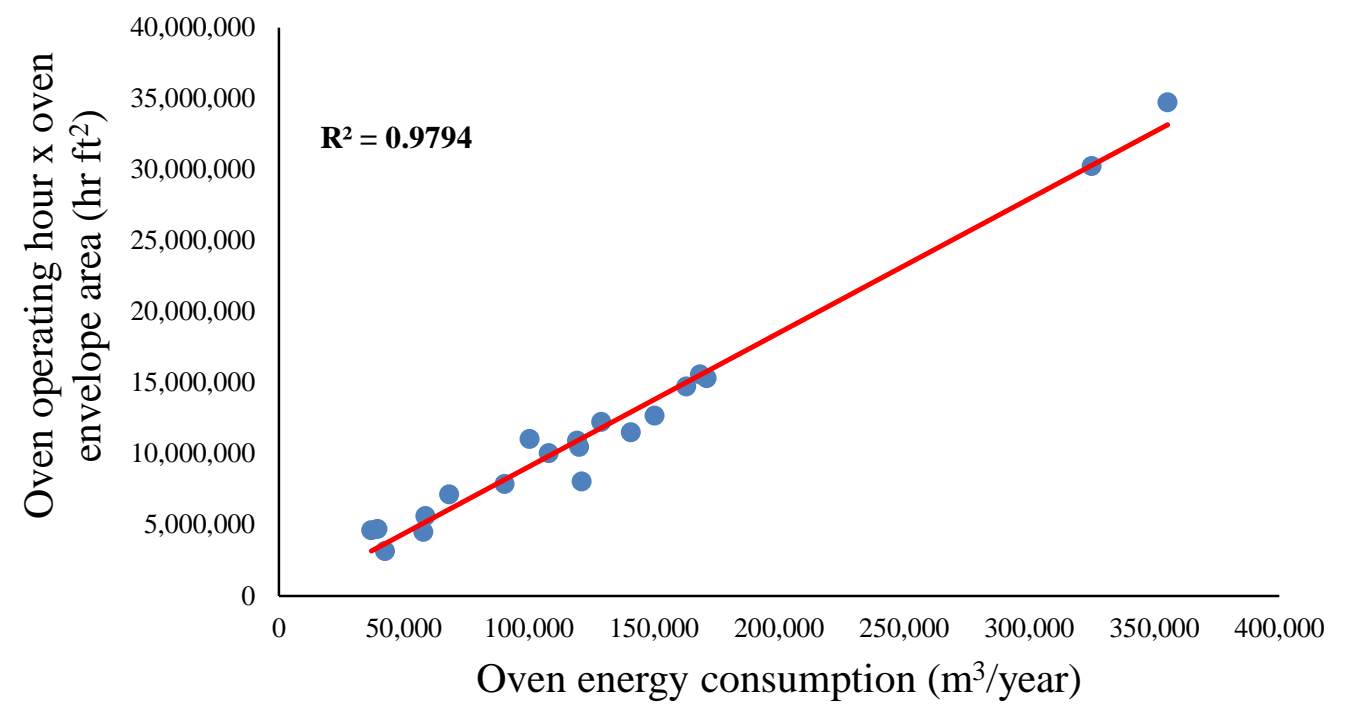

Figure 4.8: Oven consumption with operating hour $x$ oven envelope area

The value of $\mathrm{R}^{2} 0.9675$, in the Figure 4.9 shows a strong co-relation observed between these two variables. Therefore it can be estimated that oven consumption increases with the increases of oven operating hours and oven volume.

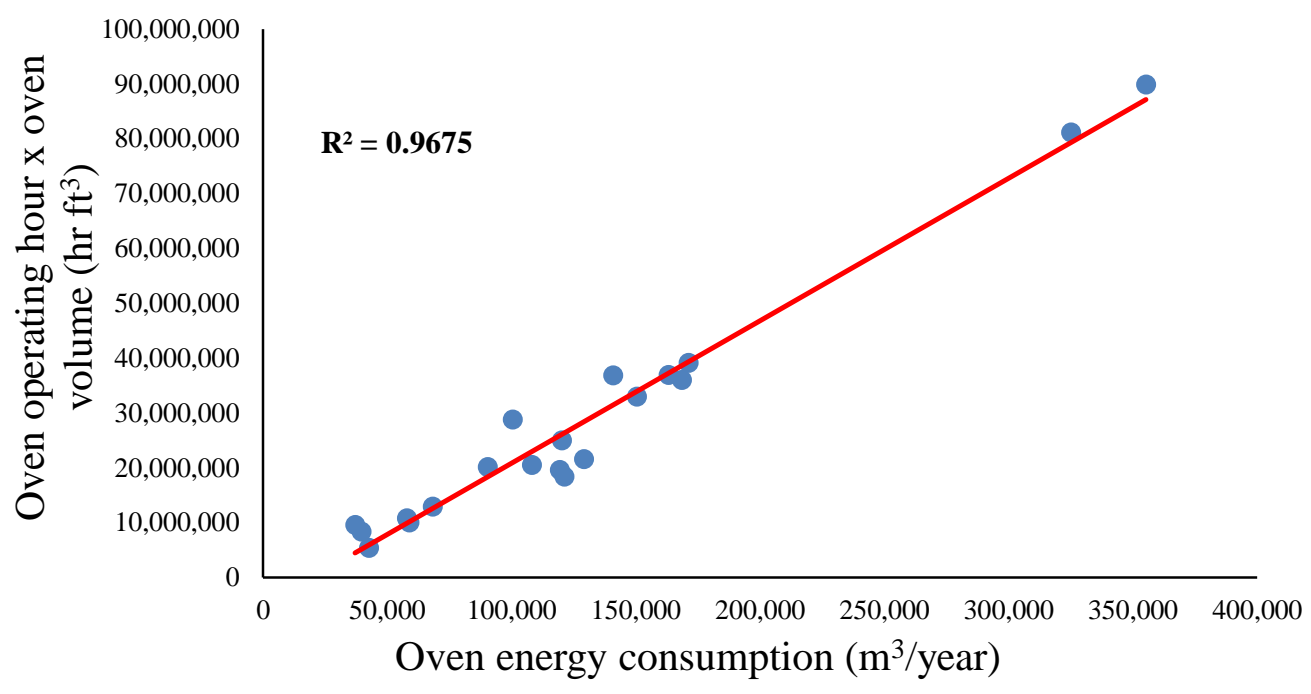

Figure 4.9: Oven consumption with operating hour $x$ oven volume 


\subsection{Energy Balance of Ovens}

Eleven SMEs and their oven energy consumptions were studied. A preliminary study of energy balance was conducted by simple heat transfer principles. The temperature inside the ovens and the set-up temperatures of the facilities were taken during on-site audit. Oven length, width, height, oven exhaust CFM, and product data were collected from the facility managers. The specific heat of oven and product material (mild steel - $0.12 \mathrm{Btu} / \mathrm{lb}{ }^{\circ} \mathrm{F}$ ) was obtained from literature $[55,56,57]$. This is estimated because of limited information about the oven shell and product from the facility.

Table 4.5: Energy balance of ovens

\begin{tabular}{|c|c|c|c|c|c|}
\hline $\begin{array}{l}\text { Company Name } \\
\text { and Oven Type }\end{array}$ & $\begin{array}{c}\text { Exhaust } \\
\text { Energy Loss }\end{array}$ & $\begin{array}{c}\text { Oven } \\
\text { Shell } \\
\text { Energy } \\
\text { Loss }\end{array}$ & $\begin{array}{c}\text { Product } \\
\text { Energy } \\
\text { Consumption }\end{array}$ & $\begin{array}{c}\text { Material } \\
\text { Handling } \\
\text { Loss }\end{array}$ & $\begin{array}{l}\text { Miscellaneous } \\
\text { Loss }\end{array}$ \\
\hline & $\left(\mathrm{m}^{3} /\right.$ year $)$ & (m³/year) & (m³ear) & $\left(\mathrm{m}^{3} /\right.$ year $)$ & $\left(\mathrm{m}^{3} /\right.$ year $)$ \\
\hline AAGF-B & 206,508 & 71,337 & 28,512 & 9,750 & 8,893 \\
\hline AASN-B & 228,748 & 81,897 & 23,722 & 10,658 & 10,255 \\
\hline AAAL-D & 57,857 & 22,500 & 34,714 & 3,606 & 1,507 \\
\hline AAAL-C & 76,371 & 27,214 & 34,714 & 4,508 & 7,467 \\
\hline AABN-D & 43,057 & 22,259 & 48,439 & 3,580 & 1,982 \\
\hline AABN-C & 86,114 & 31,229 & 48,439 & 5,134 & 218 \\
\hline AACF-D & 45,071 & 20,449 & 38,310 & 3,240 & 930 \\
\hline AACF-C & 81,127 & 30,047 & 38,310 & 4,890 & 8,625 \\
\hline AAMP-D & 49,989 & 26,229 & 45,360 & 3,870 & 3,553 \\
\hline AAMP-C & 83,314 & 33,429 & 45,360 & 5,055 & 1,351 \\
\hline AAACT-D & 13,580 & 7,335 & 17,202 & 1,277 & 3,171 \\
\hline AAACT-C & 27,160 & 10,479 & 17,202 & 1,734 & 1,234 \\
\hline AASPEC-D & 17,811 & 10,485 & 9,213 & 1,185 & 806 \\
\hline AASPEC-C & 16,181 & 9,147 & 8,176 & 1,110 & 2,385 \\
\hline AAWIL-D & 25,494 & 13,027 & 12,590 & 2,047 & 15,085 \\
\hline AAWIL-C & 56,654 & 20,109 & 12,590 & 3,012 & 8,030 \\
\hline D-78-D & 22,939 & 11,834 & 20,390 & 1,761 & 1,789 \\
\hline D-78-C & 45,878 & 16,587 & 20,390 & 2,711 & 4,794 \\
\hline D-225-D & 42,657 & 17,280 & 25,920 & 3,634 & 31,643 \\
\hline D-225-C & 85,314 & 24,686 & 25,920 & 4,224 & 660 \\
\hline
\end{tabular}


Energy balance in terms of percentage is presented in Table 4.6.

Table 4.6: Percentage energy balance of ovens

\begin{tabular}{|c|c|c|c|c|c|}
\hline $\begin{array}{c}\text { Company Name and } \\
\text { Oven Type }\end{array}$ & $\begin{array}{c}\text { Percent } \\
\text { Exhaust Energy } \\
\text { Loss }\end{array}$ & $\begin{array}{c}\text { Percent } \\
\text { Oven Shell } \\
\text { Energy } \\
\text { Loss }\end{array}$ & $\begin{array}{c}\text { Percent } \\
\text { Product } \\
\text { Energy } \\
\text { Consumption }\end{array}$ & $\begin{array}{c}\text { Percent } \\
\text { Material } \\
\text { Handling } \\
\text { Loss }\end{array}$ & $\begin{array}{c}\text { Percent } \\
\text { Miscellaneous } \\
\text { Loss }\end{array}$ \\
\cline { 2 - 6 } & $\mathbf{( \% )}$ & $\mathbf{( \% )}$ & $\mathbf{( \% )}$ & $\mathbf{( \% )}$ & $\mathbf{( \% )}$ \\
\hline AAGF-B & 63 & 22 & 9 & 3 & 3 \\
\hline AASN-B & 64 & 23 & 7 & 3 & 3 \\
\hline AAAL-D & 48 & 19 & 29 & 3 & 1 \\
\hline AAAL-C & 51 & 18 & 23 & 3 & 5 \\
\hline AABN-D & 35 & 19 & 41 & 3 & 2 \\
\hline AABN-C & 50 & 19 & 28 & 3 & 1 \\
\hline AACF-D & 42 & 18 & 24 & 3 & 1 \\
\hline AACF-C & 50 & 20 & 35 & 3 & 5 \\
\hline AAMP-D & 39 & 27 & 3 & 3 \\
\hline AAMP-C & 49 & 17 & 30 & 3 & 7 \\
\hline AAACT-D & 33 & 27 & 23 & 3 & 2 \\
\hline AAACT-C & 47 & 25 & 22 & 3 & 6 \\
\hline AASPEC-D & 45 & 19 & 18 & 3 & 22 \\
\hline AASPEC-C & 44 & 20 & 13 & 3 & 8 \\
\hline AAWIL-D & 38 & 20 & 35 & 3 & 3 \\
\hline AAWIL-C & 56 & 18 & 23 & 3 & 5 \\
\hline D-78-D & 39 & 14 & 21 & 3 & 26 \\
\hline D-78-C & 51 & 18 & 18 & 3 & 1 \\
\hline D-225-D & 35 & & & \\
\hline D-225-C & 60 & & & 3 & 2 \\
\hline
\end{tabular}

\subsubsection{Bake ovens}

Of the eleven SMEs studied, two companies have bake ovens. The bake ovens consume most of the plant's energy. Significant energy losses were observed in different processes, specifically exhaust, through the shell, during material handling, energy absorbed by the product and miscellaneous energy loss. Studied bakeries were observed running 24 hours a day without limited halts. Energy loss with flue gas as exhaust was observed to be the major loss. Data from only two companies bake oven are not enough for analysis and determining performing 
parameters. Figure 4.10 presents the energy balance of bake ovens where exhaust loss is the highest, shell loss is second highest, and product energy consumption is third highest.

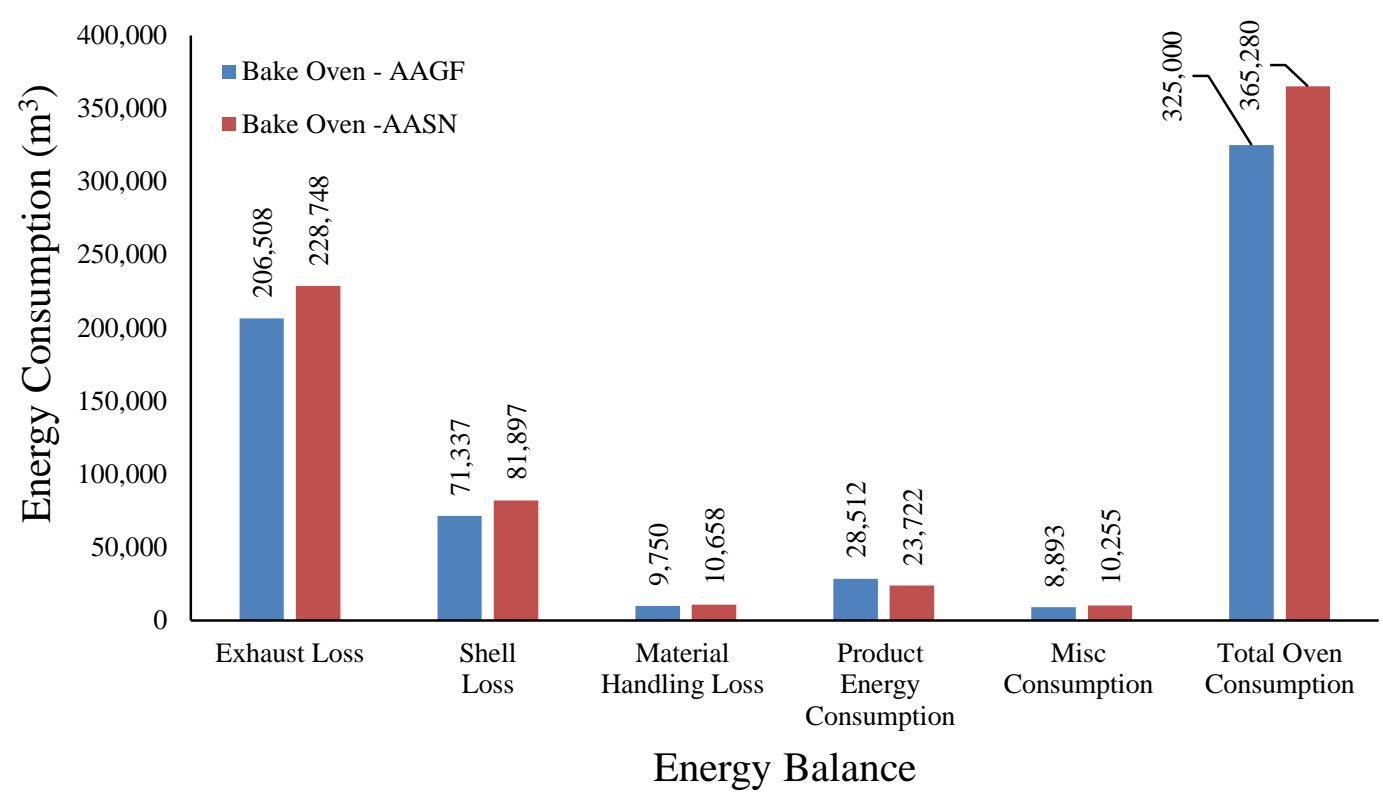

Figure 4.10: Energy balance of bake ovens

The study revealed that major energy loss occurred due to exhaust from the ovens. The energy loss from oven exhaust was from $63 \%$ to $64 \%$. Oven shells had the second highest energy consumption from $22 \%$ to $23 \%$. The third major energy consumption was for the product, which accounted for $7 \%$ to $9 \%$. These findings are presented in Figures 4.11. A significant result from this analysis could not be done due to imitated data. Both bake ovens are found identical in this analysis. 


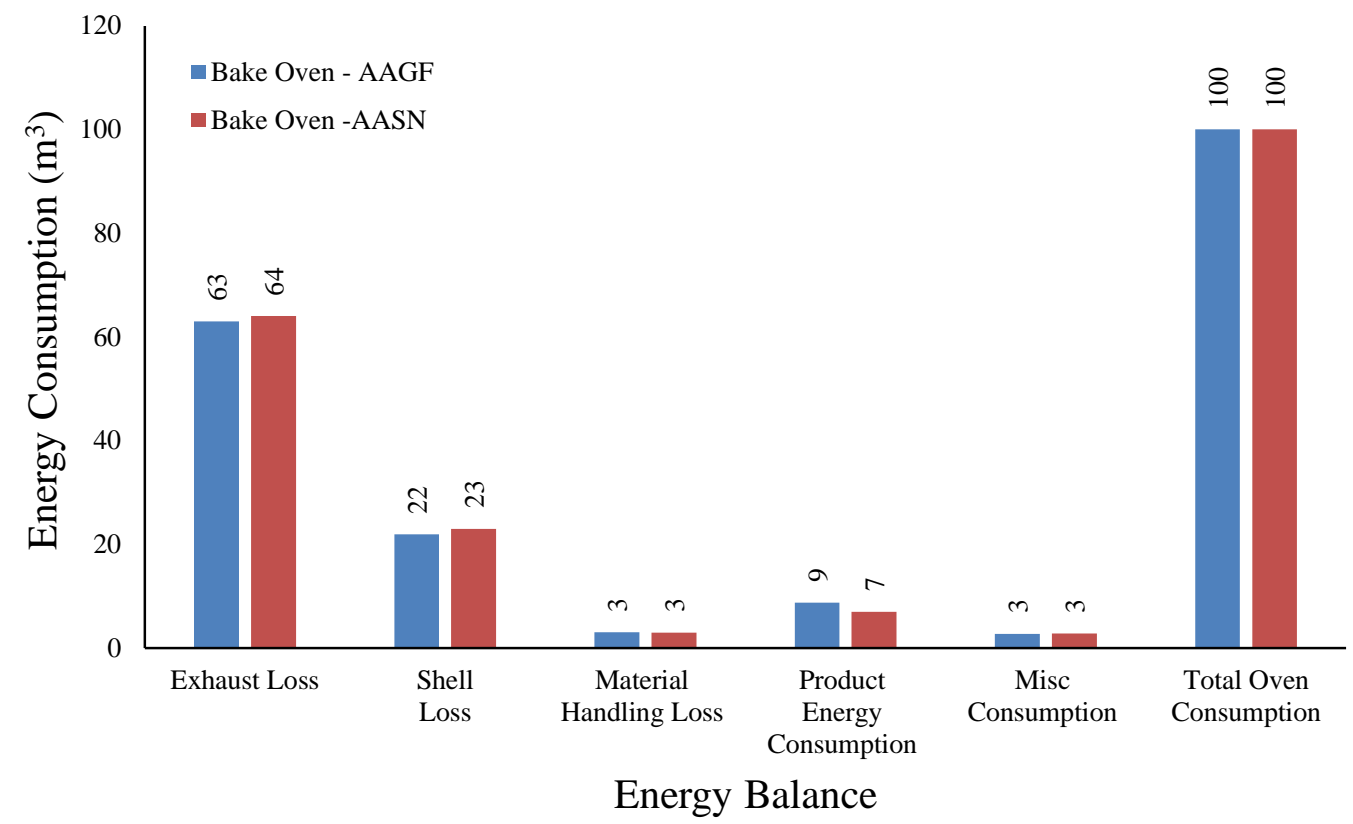

Figure 4.11: Percent energy balance of bake ovens

\subsubsection{Energy Balance of Dry-off Oven}

Nine out of the eleven audited sites were finishing process industries that had dry-off ovens and cure ovens. Energy consumption of dry-off ovens are presented in the subsequent sections. This study observed that dry-off ovens consumed $26 \%$ to $48 \%$ of the total process energy depending on the oven size, the type of production, and the hours of operation. A comparative study of the energy consumed by the ovens of different companies is presented in Figure 4.12. Each cluster in Figure 4.12 represents the type of loss from dry-off ovens of each company. 


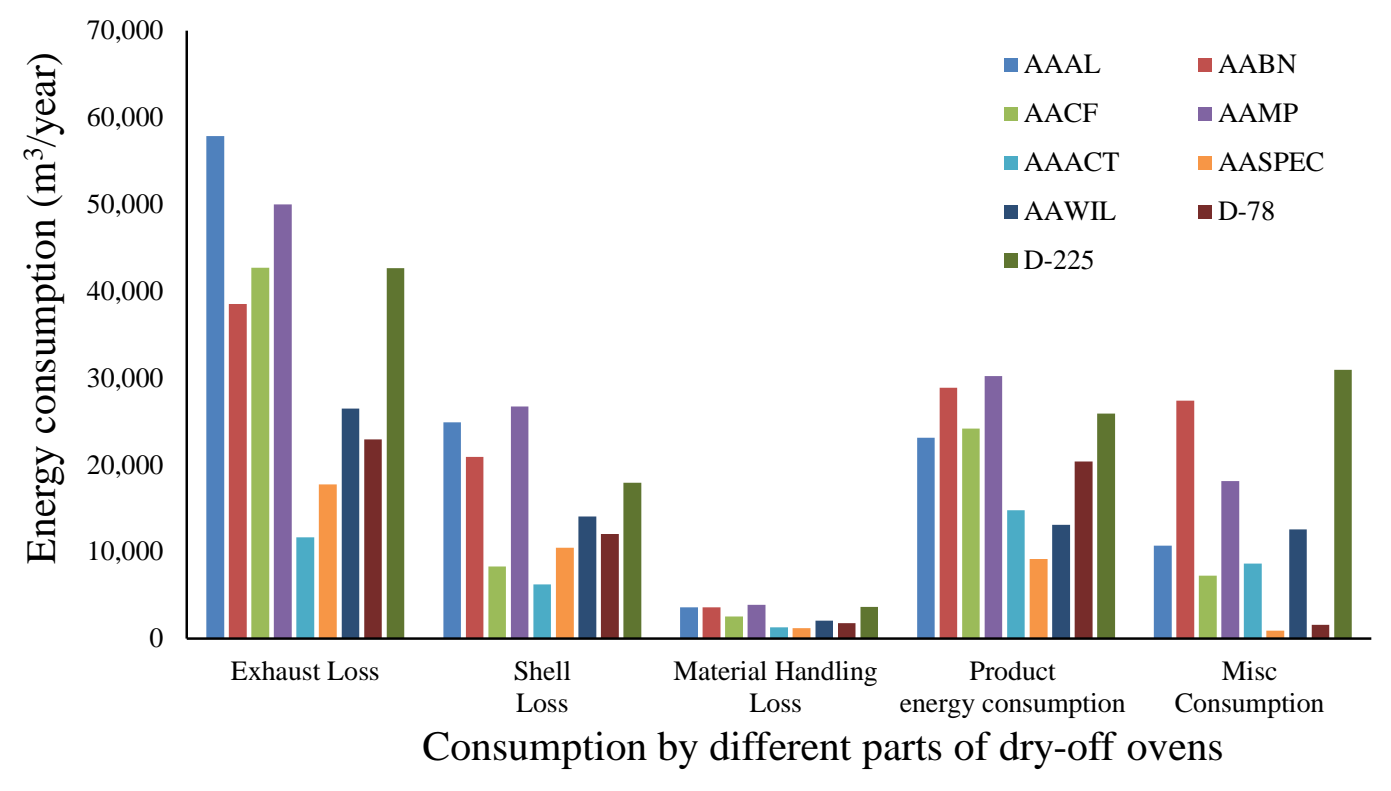

Figure 4.12: Energy balance of different Dry-Off Oven

The first cluster of bars represents energy loss through exhaust, the second cluster of bars is energy loss through the shell, the third cluster of bars represents material handling energy consumption, the fourth cluster of bars is product energy consumption, and the fifth cluster of bars represents miscellaneous loss. Miscellaneous includes radiation loss and shell opening loss, among others.

Figure 4.13 displays the percent exhaust loss of the audited companies' dry-off ovens. As seen in Figure 4.13, company AACF displayed the highest exhaust loss (53\%). 


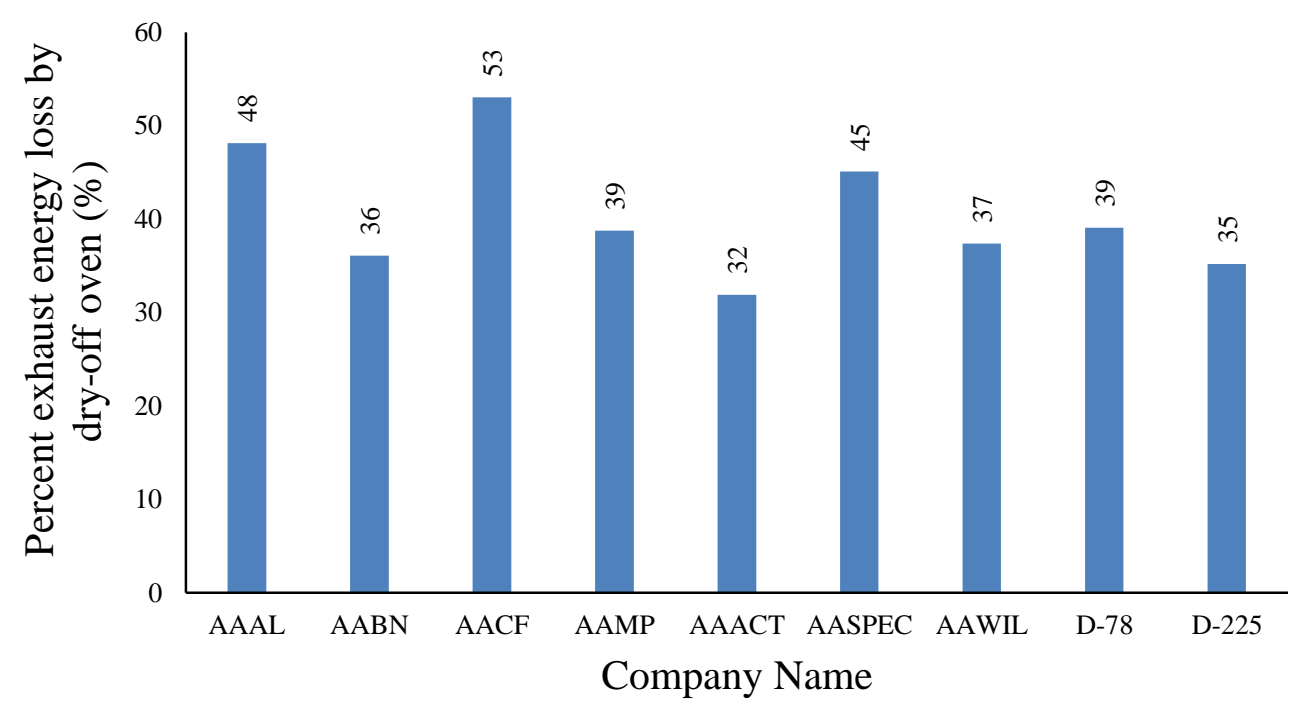

Figure 4.13: Percent energy loss due to exhaust from different dry-off ovens

Figure 4.14 displays the percent shell loss of the audited companies' dry-off ovens. As can be seen, company D-225 displayed the lowest shell loss (14\%) while company AASPEC displayed the highest shell loss (27\%).

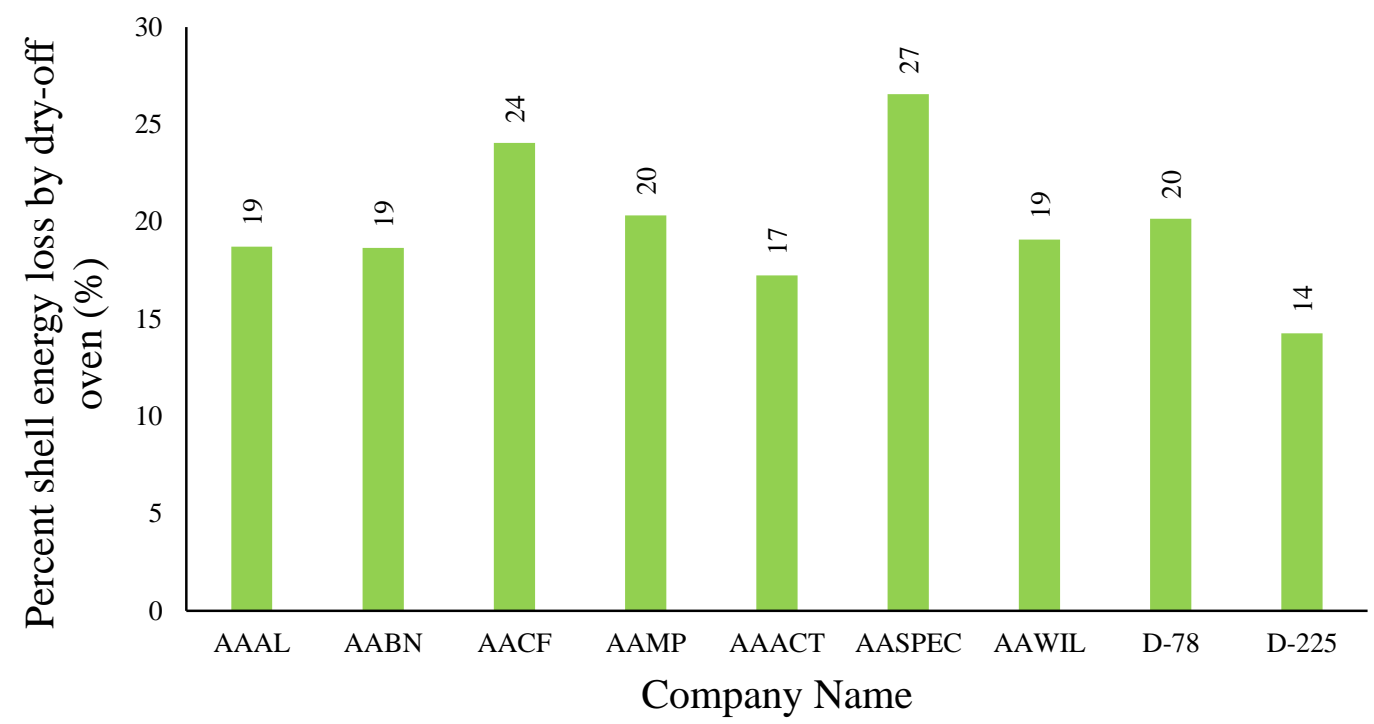

Figure 4.14: Percent shell energy loss from different dry-off ovens 
Figure 4.15 displays the percent product energy consumption of the audited companies' dry-off ovens. Product energy consumption includes the amount of energy required to process the product. Of all the companies, AAWIL displayed lowest consumption (18\%) while AAACT and D-78 displayed the highest consumption (45\%).

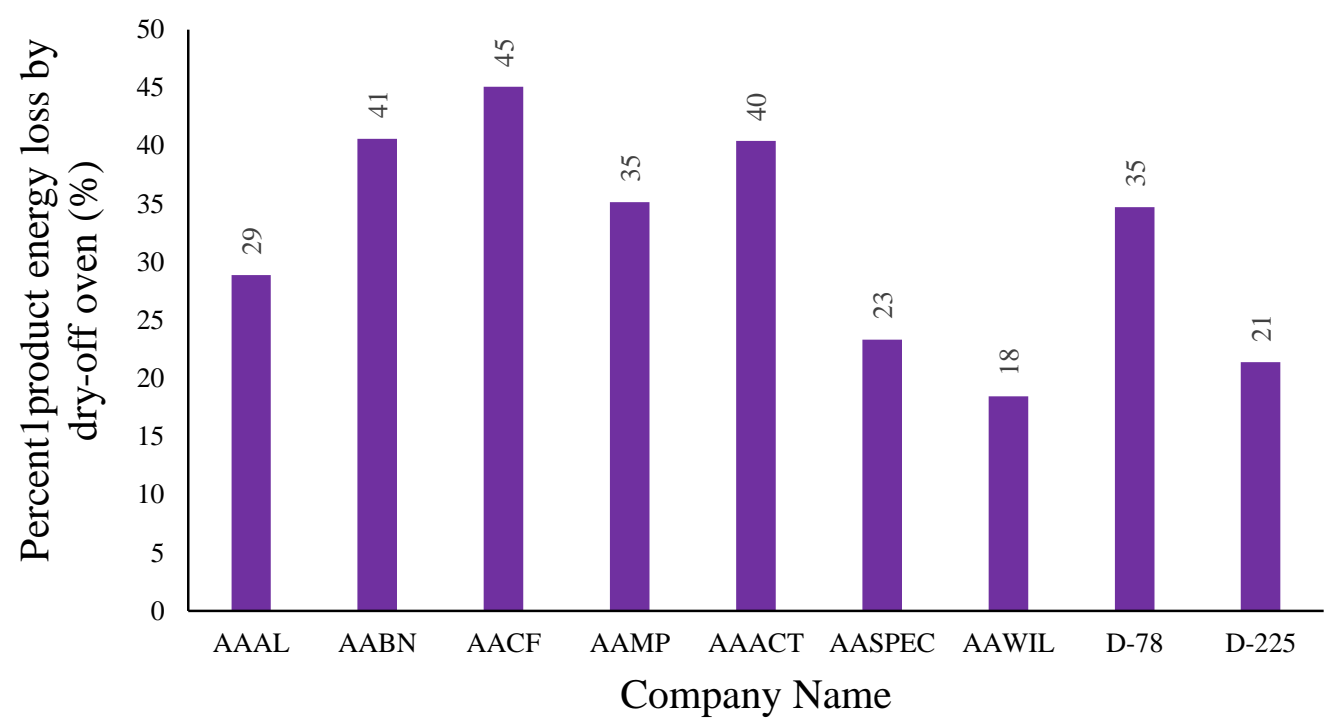

Figure 4.15: Percent product energy consumption from different dry-off ovens

\subsubsection{Energy Balance of Cure Oven}

This study observed that cure ovens consume $31 \%$ to $68 \%$ of the process energy depending on the oven size, production type, and hours of operation. A comparison of the energy consumption of cure ovens at the audited sites is presented in Figure 4.16. The first cluster of bars in the diagram represents energy loss due to exhaust, the second cluster of bars is energy loss through the shell, the third cluster of bars represents energy consumption from handling material, the fourth cluster of bars is product energy consumption, and the fifth cluster of bars represents miscellaneous losses. 


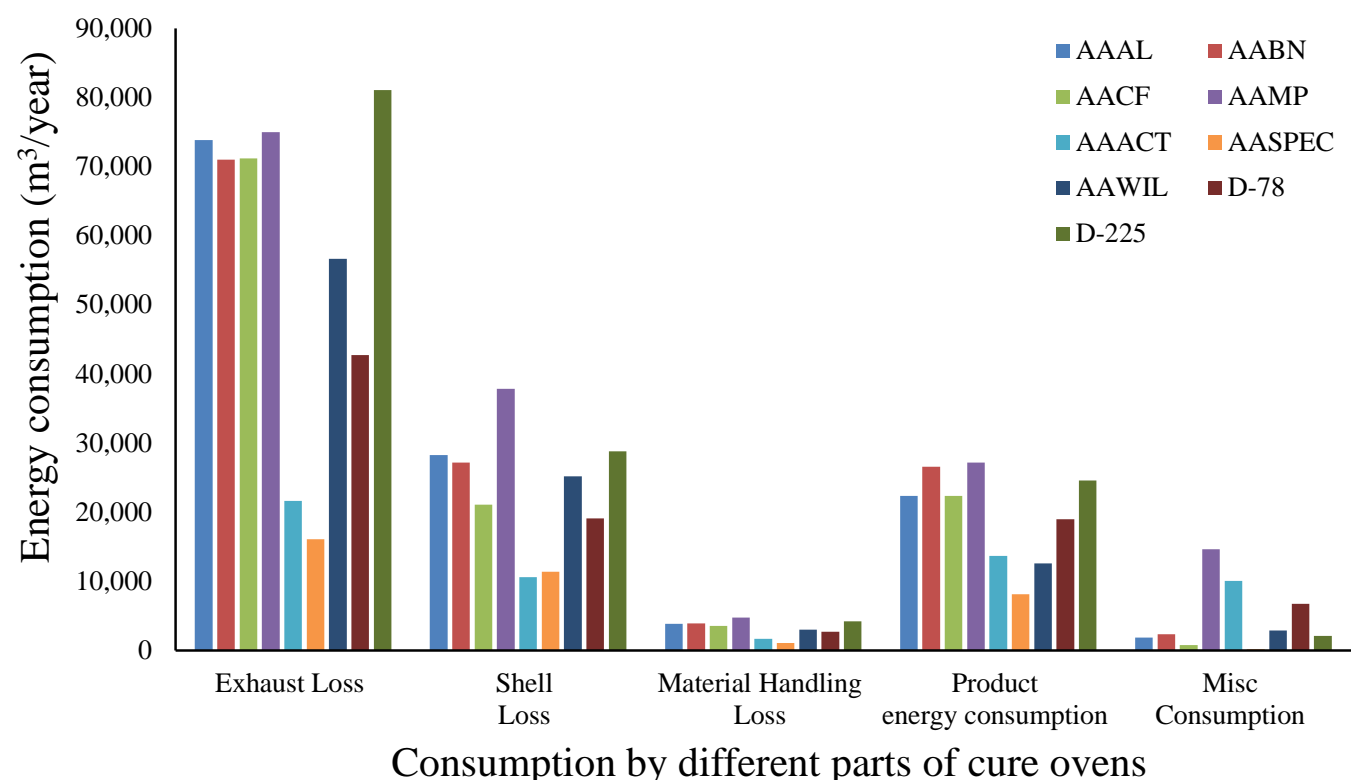

Figure 4.16: Energy balance of different cure ovens

Figure 4.17 displays the percent exhaust loss of the audited companies' cure ovens. As seen in Figure 4.17, company D-225 displayed the highest exhaust loss (61\%) and company AASPEC displayed the lowest exhaust loss (44\%).

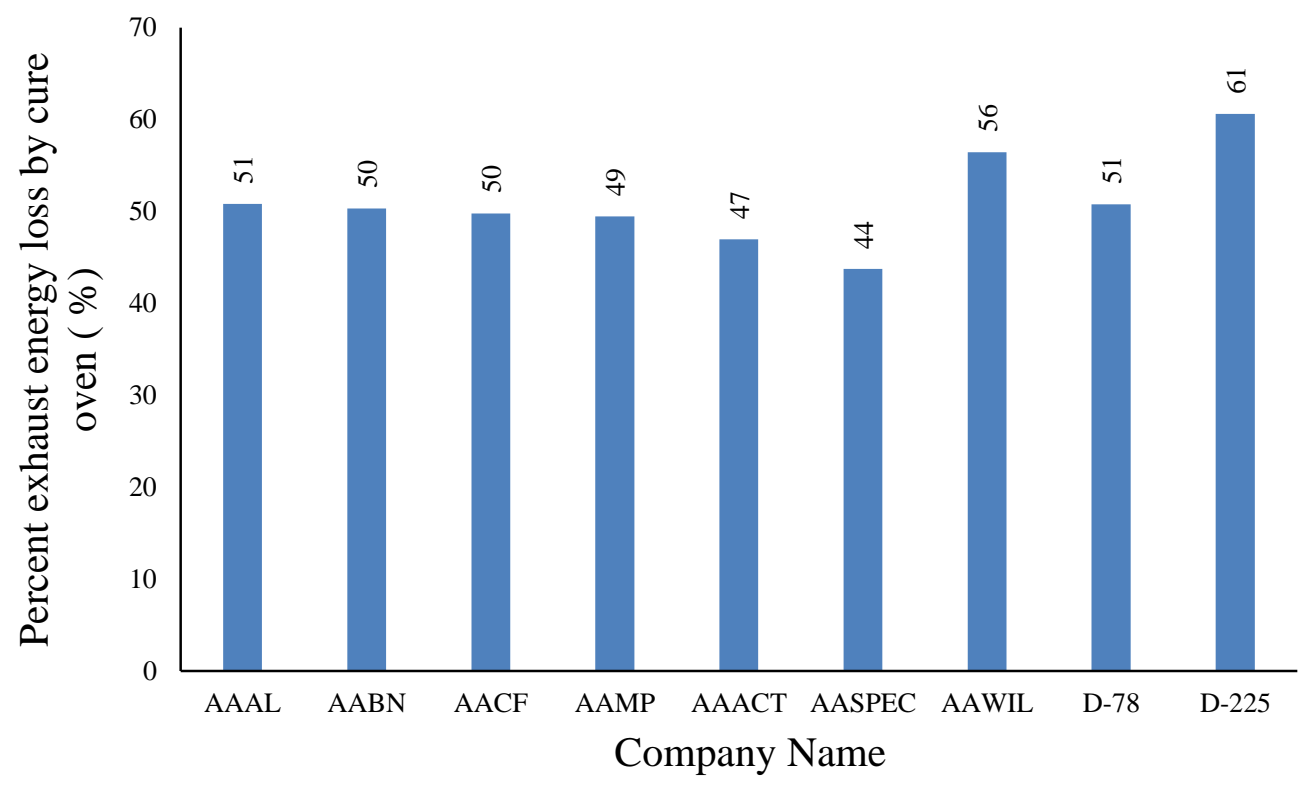

Figure 4.17: Percent exhaust energy loss from different cure ovens 
Figure 4.18 displays the percent shell loss of the audited companies' cure ovens. As can be seen, company AAAL, AABN, AACF, AAACT, D-78, and D-225 had the lowest shell loss (18\%) while company AASPEC displayed the highest shell loss (25\%).

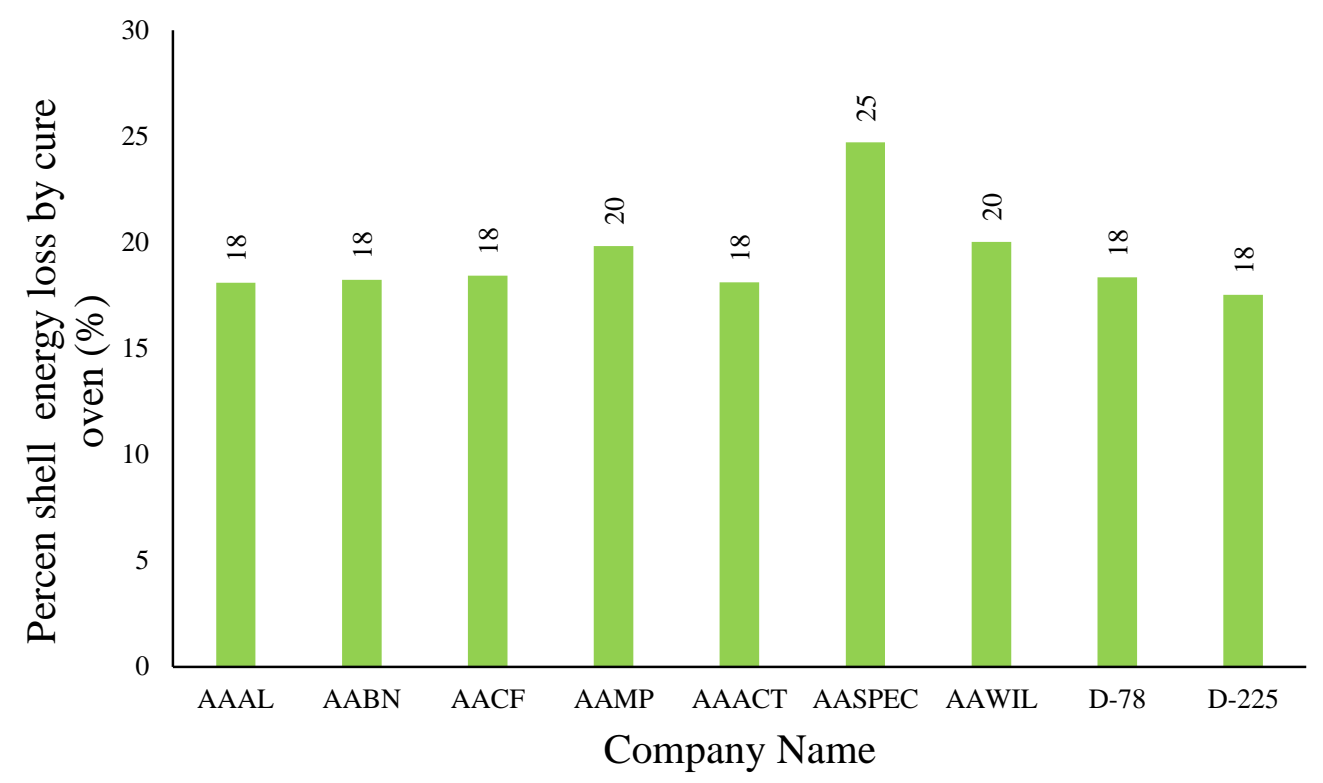

Figure 4.18: Percent shell loss from different cure ovens

Figure 4.19 displays the percent product energy consumption of the cure ovens of the audited companies. AAWIL had the lowest (13\%), while AAACT had the highest product energy consumption loss $(30 \%)$. 


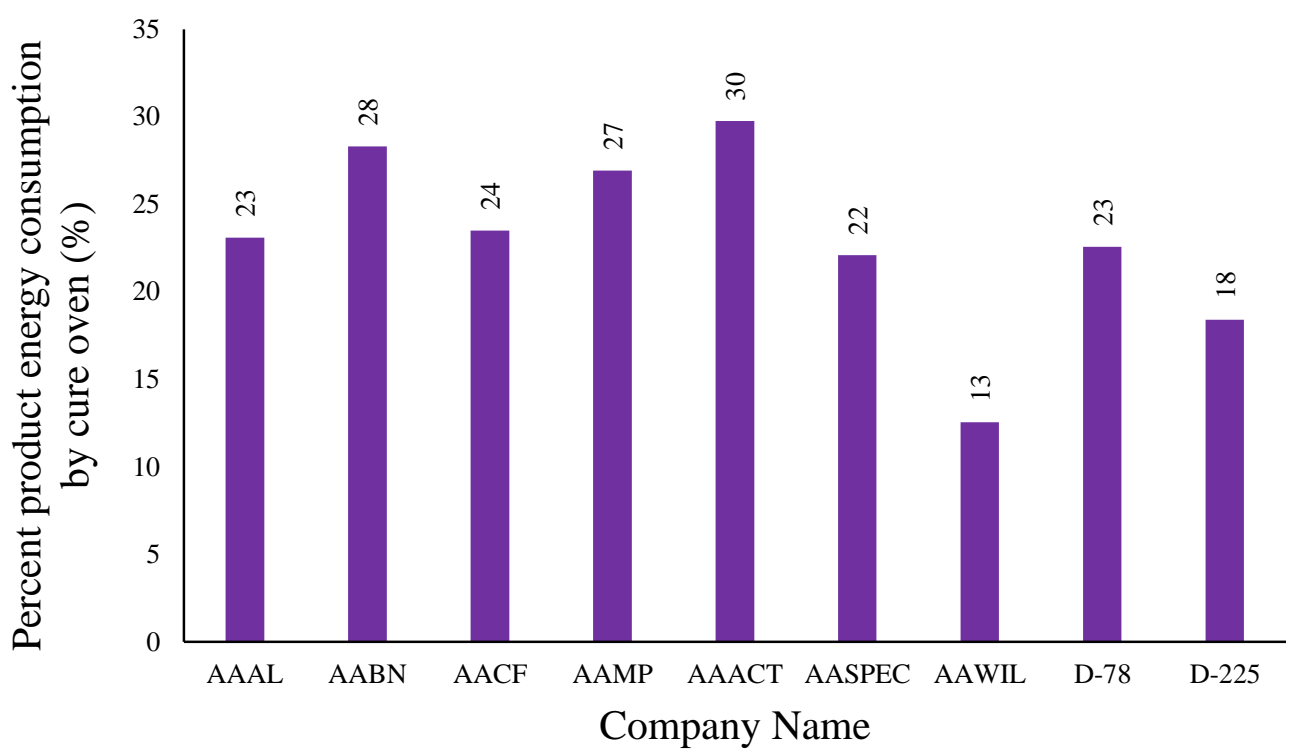

Figure 4.19: Percent product energy consumption from different cure ovens

Oven efficiency can be estimated using different parameters - exhaust energy loss, shell energy loss, and miscellaneous energy loss - which account for energy consumption. It was observed that although one oven might be efficient in terms of exhaust loss, it could, at the same time, experience more losses through shell envelope. Therefore, all parameters of energy consumption and their comparative consumption indicators should be used to identify the overall best performing oven.

\subsection{Exhaust Loss Analysis with Different Parameters}

Based on analysis, $33 \%$ to $64 \%$ of oven energy input is wasted as exhaust. In the subsequent section, the causes of this major loss and potential savings were analyzed. Exhaust losses from ovens are presented in Table 4.7. 
Table 4.7: Exhaust energy loss and temperature difference

\begin{tabular}{|c|c|c|c|}
\hline \multirow[t]{2}{*}{$\begin{array}{l}\text { Company Name } \\
\text { and Oven Type }\end{array}$} & $\begin{array}{c}\text { Exhaust Energy } \\
\text { Loss }\end{array}$ & $\begin{array}{l}\text { Temperature } \\
\text { Difference }\end{array}$ & $\begin{array}{c}\text { Temperature } \\
\text { Difference }\end{array}$ \\
\hline & (m³/year) & $\left({ }^{\circ} \mathbf{F}\right)$ & $\left({ }^{\circ} \mathrm{C}\right)$ \\
\hline AAGF-B & 206,508 & 330 & 183 \\
\hline AASN-B & 228,748 & 330 & 183 \\
\hline AAAL-D & 57,857 & 300 & 167 \\
\hline AAAL-C & 76,371 & 300 & 167 \\
\hline AABN-D & 43,057 & 285 & 158 \\
\hline AABN-C & 86,114 & 285 & 158 \\
\hline AACF-D & 45,071 & 285 & 158 \\
\hline AACF-C & 81,127 & 285 & 158 \\
\hline AAMP-D & 49,989 & 300 & 167 \\
\hline AAMP-C & 83,314 & 300 & 167 \\
\hline AAACT-D & 13,580 & 326 & 181 \\
\hline AAACT-C & 27,160 & 326 & 181 \\
\hline AASPEC-D & 17,811 & 311 & 173 \\
\hline AASPEC-C & 16,181 & 276 & 153 \\
\hline AAWIL-D & 25,494 & 255 & 142 \\
\hline AAWIL-C & 56,654 & 255 & 142 \\
\hline D-78-D & 22,939 & 295 & 164 \\
\hline D-78-C & 45,878 & 295 & 164 \\
\hline D-225-D & 42,657 & 300 & 167 \\
\hline D-225-C & 85,314 & 300 & 167 \\
\hline
\end{tabular}

Figure 4.20 displays exhaust energy loss with operating temperature difference of ovens. Analysis shows that AASN-B had the highest, while AASPEC-D had the lowest, exhaust energy loss. It can be seen that operating temperature difference is a major factor in exhaust loss. Other contributing factors are burner capacity, proper burning of gas, air flow inside the oven, and oven volume. 


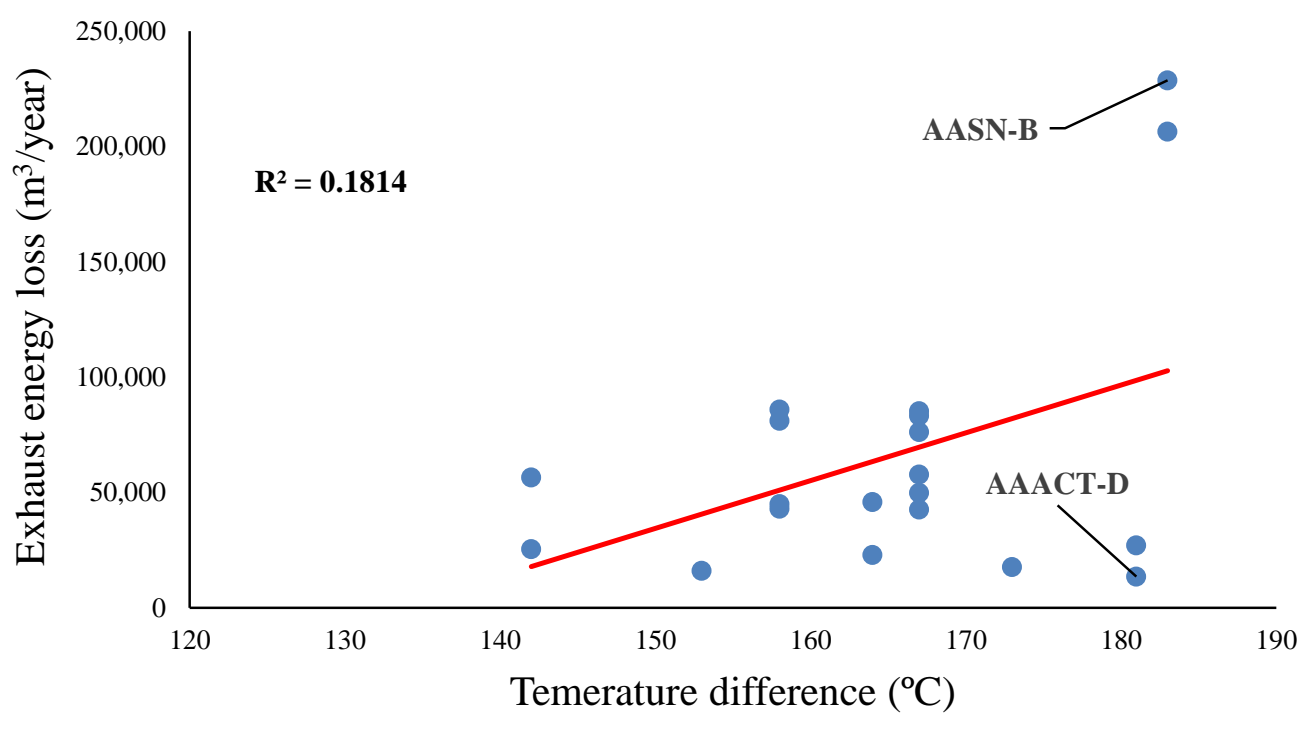

Figure 4.20: Exhaust energy loss vs. temperature difference

Figure 4.21 displays exhaust energy loss with oven envelope area. Analysis shows that AASN-B had the highest, while AAACT-D had the lowest exhaust energy loss.

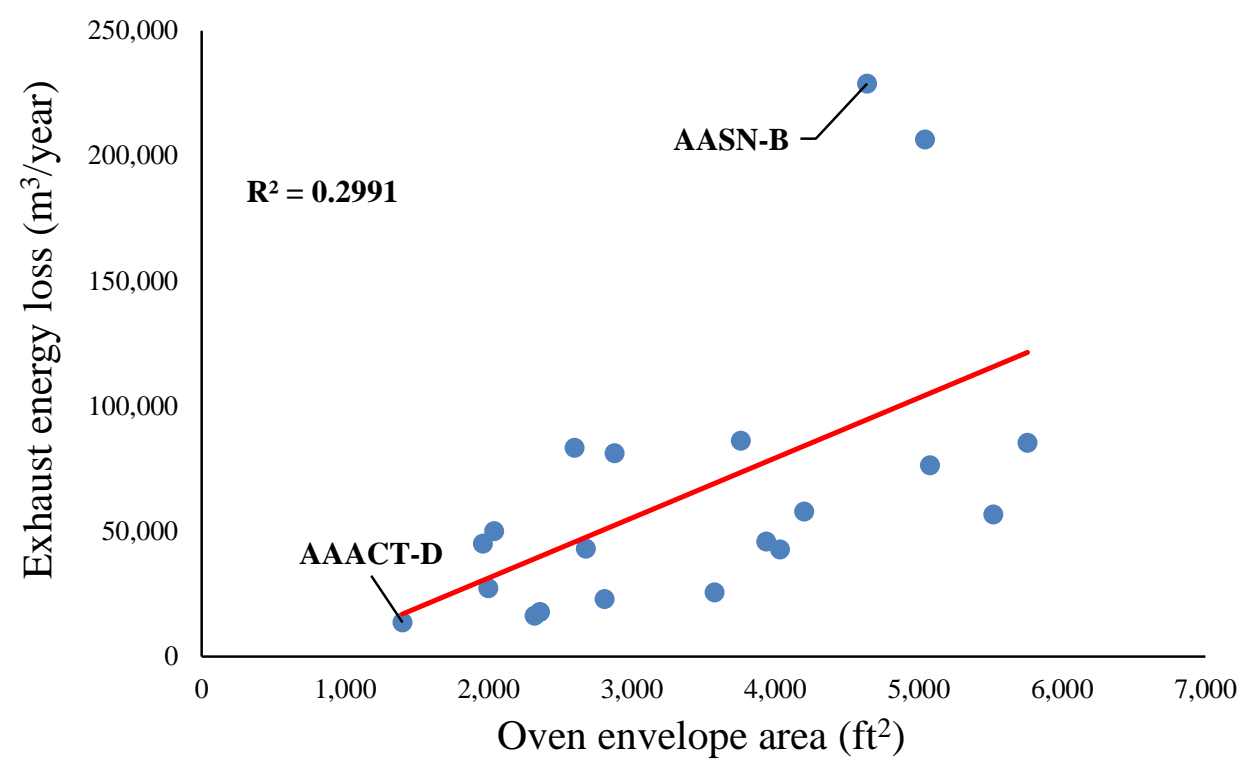

Figure 4.21: Exhaust energy loss vs. oven envelop area 
Figure 4.22 displays oven CFM verses exhaust loss. The $\mathrm{R}^{2}$ value shows that there is no significant correlation between these two parameters; however, an increasing trend of exhaust energy loss was observed with increasing of CFM.

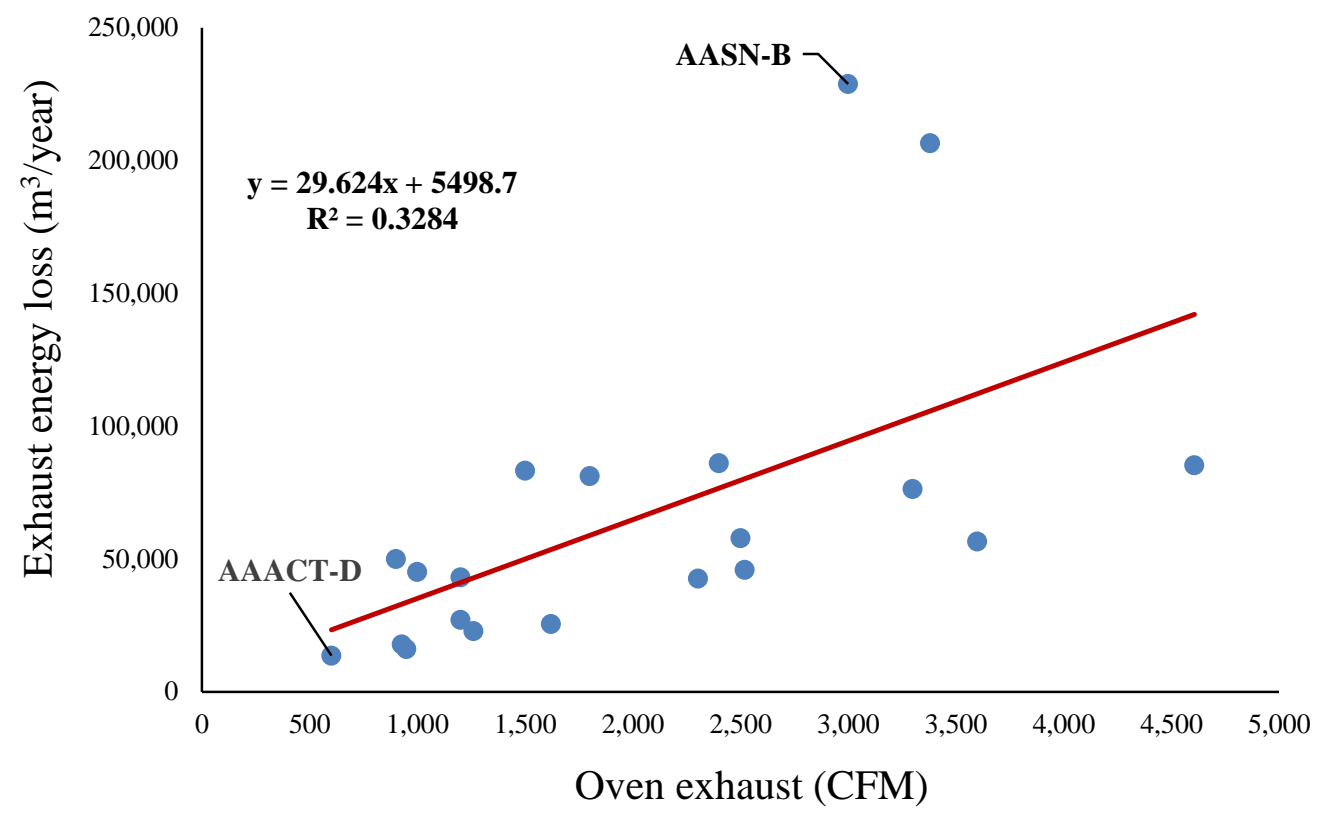

Figure 4.22: Oven CFM vs. exhaust loss

Figures $4.20,4.21$, and 4.22 show that only a few points are widely dispersed in the scattered plot from the trend line. Oven envelope area, oven volume, operating temperature, and CFM contributed energy loss. Excess air combustion is a major cause of exhaust energy loss which results in longer processing time and higher operating temperature. The reasons why there are outlying points in those graphs are dissimilar oven sizes, operating temperatures, and products. 


\subsection{Shell Energy Loss Analysis with Different Parameters}

Table 4.8 displays the summary of shell loss by unit area of envelope and unit volume of oven. Column 5 displays the energy loss per unit area while column 6 displays the energy loss per unit volume. Potential savings opportunities are there of those ovens that have high values of energy loss per square footage and unit volume of oven.

Table 4.8: Oven shell loss per unit area of envelope and per unit volume of oven

\begin{tabular}{|c|c|c|c|c|c|}
\hline $\begin{array}{l}\text { Company } \\
\text { Name }\end{array}$ & $\begin{array}{l}\text { Oven } \\
\text { Area }\end{array}$ & $\begin{array}{c}\text { Oven } \\
\text { Volume }\end{array}$ & $\begin{array}{c}\text { Shell } \\
\text { Energy Loss }\end{array}$ & $\begin{array}{c}\text { Energy Loss per } \\
\text { Square Footage } \\
\text { of Oven } \\
\text { Envelope } \\
\left(\mathbf{m}^{3} / \mathbf{f t}^{2}\right)\end{array}$ & $\begin{array}{c}\text { Energy Loss } \\
\text { per } \\
\text { Unit Volume } \\
\text { of Oven } \\
\left(\mathbf{m}^{\mathbf{3}} / \mathbf{f t}^{3}\right)\end{array}$ \\
\hline & & & & & \\
\hline AAGF-B & 5,044 & 13,520 & 71,337 & 14.14 & 5.28 \\
\hline AASN-B & 4,640 & 12,000 & 81,897 & 17.65 & 6.82 \\
\hline AAAL-D & 4,200 & 10,000 & 22,500 & 5.36 & 2.25 \\
\hline AAAL-C & 5,080 & 13,200 & 27,214 & 5.36 & 2.06 \\
\hline AABN-D & 2,680 & 4,800 & 22,259 & 8.31 & 4.64 \\
\hline AABN-C & 3,760 & 9,600 & 31,229 & 8.31 & 3.25 \\
\hline AACF-D & 1,960 & 4,000 & 20,449 & 10.43 & 5.11 \\
\hline AACF-C & 2,880 & 7,200 & 30,047 & 10.43 & 4.17 \\
\hline AAMP-D & 2,040 & 3,600 & 26,229 & 12.86 & 7.29 \\
\hline AAMP-C & 2,600 & 6,000 & 33,429 & 12.86 & 5.57 \\
\hline AAACT-D & 1,400 & 2,400 & 7,335 & 5.24 & 3.06 \\
\hline AAACT-C & 2,000 & 4,800 & 10,479 & 5.24 & 2.18 \\
\hline AASPEC-D & 2,360 & 4,200 & 10,485 & 4.44 & 2.50 \\
\hline AASPEC-C & 2,320 & 4,800 & 9,147 & 3.94 & 1.91 \\
\hline AAWIL-D & 3,576 & 6,480 & 13,027 & 3.64 & 2.01 \\
\hline AAWIL-C & 5,520 & 14,400 & 20,109 & 3.64 & 1.40 \\
\hline D-78-D & 2,808 & 5,040 & 11,834 & 4.21 & 2.35 \\
\hline D-78-C & 3,936 & 10,080 & 16,587 & 4.21 & 1.65 \\
\hline D-225-D & 4,032 & 9,216 & 17,280 & 4.29 & 1.88 \\
\hline D-225-C & 5,760 & 18,432 & 24,686 & 4.29 & 1.34 \\
\hline
\end{tabular}

Figure 4.23 and Figure 4.24 display shell energy loss per unit area of oven envelope and oven

volume. AAMP-D shows the highest and D-225-C is the lowest on energy loss per unit volume 
while AASN-B shows the highest and AAWIL-D and AAWIL-C shows the lowest energy loss per square footage of oven envelope.

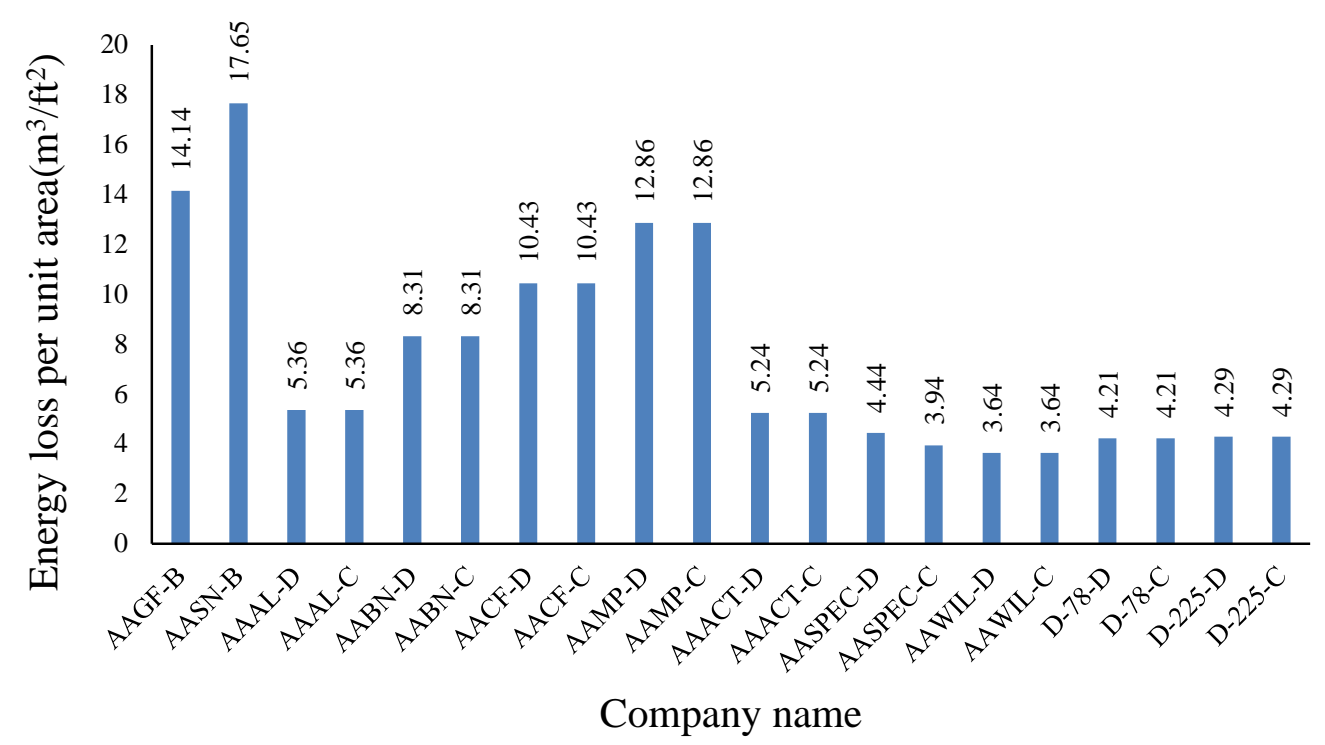

Figure 4.23: Shell energy loss per unit area of oven

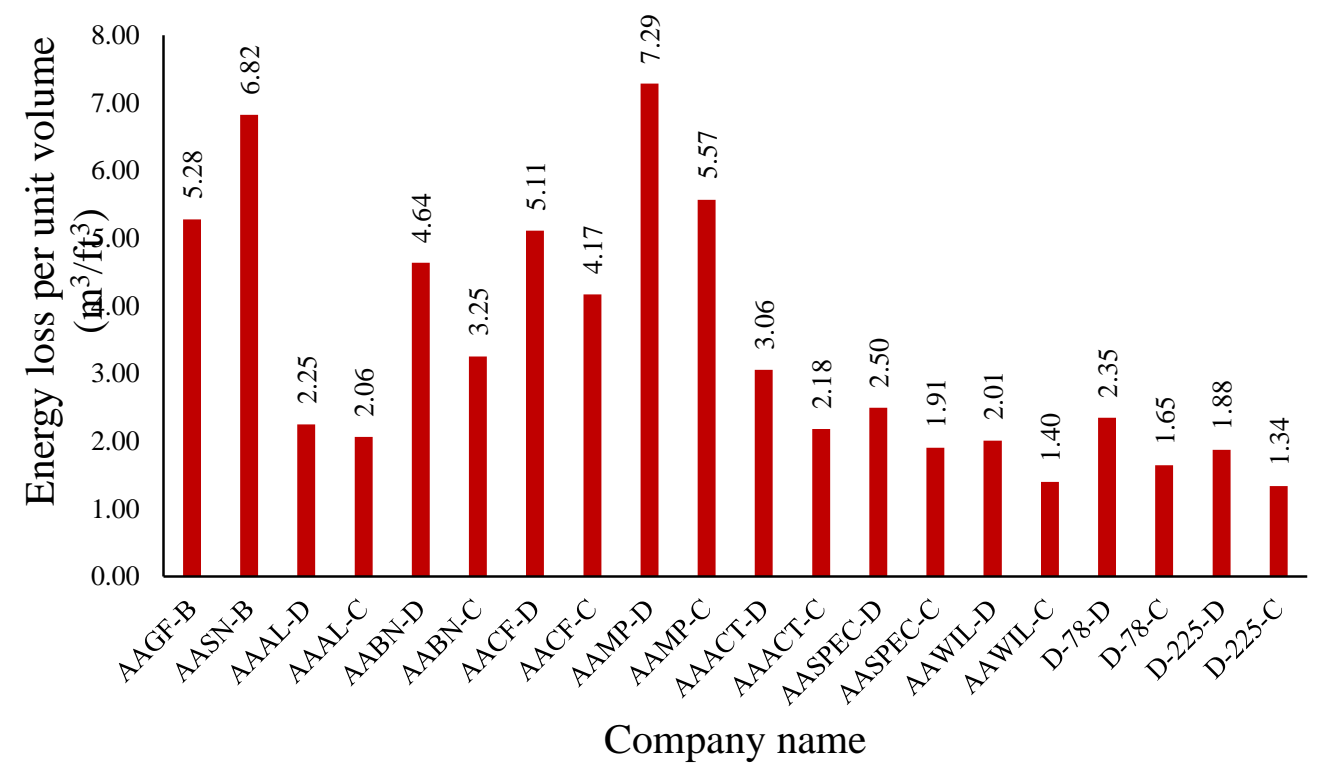

Figure 4.24: Shell energy loss per unit volume of oven 
Table 4.9 displays shell loss and temperature difference. Audited companies ovens were found operating temperature differences from $255^{\circ} \mathrm{F}$ to $330^{\circ} \mathrm{F}\left(142^{\circ} \mathrm{C}\right.$ to $\left.183^{\circ} \mathrm{C}\right)$. AASN-B shows the highest shell loss while AAACT-D shows the lowest shell loss among the ovens. Highest temperature difference does not show the highest shell loss, on the other hand lowest temperature difference does not shows the lowest.

Table 4.9: Oven shell loss and temperature difference

\begin{tabular}{|c|c|c|c|}
\hline $\begin{array}{c}\text { Name of } \\
\text { Company }\end{array}$ & Shell Energy Loss & $\begin{array}{c}\text { Temperature } \\
\text { Difference }\end{array}$ & $\begin{array}{c}\text { Temperature } \\
\text { Difference }\end{array}$ \\
\cline { 2 - 4 } & $\mathbf{( \mathbf { m } ^ { 3 } / \mathbf { y e a r } )}$ & $\mathbf{(} \mathbf{F})$ & $\mathbf{( { } ^ { \mathbf { } } \mathbf { C } )}$ \\
\hline AAGF-B & 71,337 & 330 & 183 \\
\hline AASN-B & 81,897 & 330 & 183 \\
\hline AAAL-D & 22,500 & 300 & 167 \\
\hline AAAL-C & 27,214 & 300 & 167 \\
\hline AABN-D & 22,259 & 285 & 158 \\
\hline AABN-C & 31,229 & 285 & 158 \\
\hline AACF-D & 20,449 & 285 & 158 \\
\hline AACF-C & 30,047 & 285 & 158 \\
\hline AAMP-D & 26,229 & 300 & 167 \\
\hline AAMP-C & 33,429 & 300 & 167 \\
\hline AAACT-D & 7,335 & 326 & 181 \\
\hline AAACT-C & 10,479 & 326 & 181 \\
\hline AASPEC-D & 10,485 & 311 & 173 \\
\hline AASPEC-C & 9,147 & 276 & 153 \\
\hline AAWIL-D & 13,027 & 255 & 142 \\
\hline AAWIL-C & 20,109 & 255 & 142 \\
\hline D-78-D & 11,834 & 295 & 164 \\
\hline D-78-C & 16,587 & 295 & 164 \\
\hline D-225-D & 17,280 & 300 & 167 \\
\hline D-225-C & 24,686 & 300 & 167 \\
\hline
\end{tabular}

There might be other factors contributing to shell loss. Those are: oven insulation, panel thickness, and oven opening etc. Analysis performed with available data and presented in the 
following sections. This analysis was performed because shell loss found the second contributing factor of oven's energy loss.

Figure 4.25 displays shell loss vs. temperature difference. $\mathrm{R}^{2}$ value shows that the correlation between these two parameters is not strong. Analysis shows AASN-B has the highest while AAACT-D has the lowest shell loss among others.

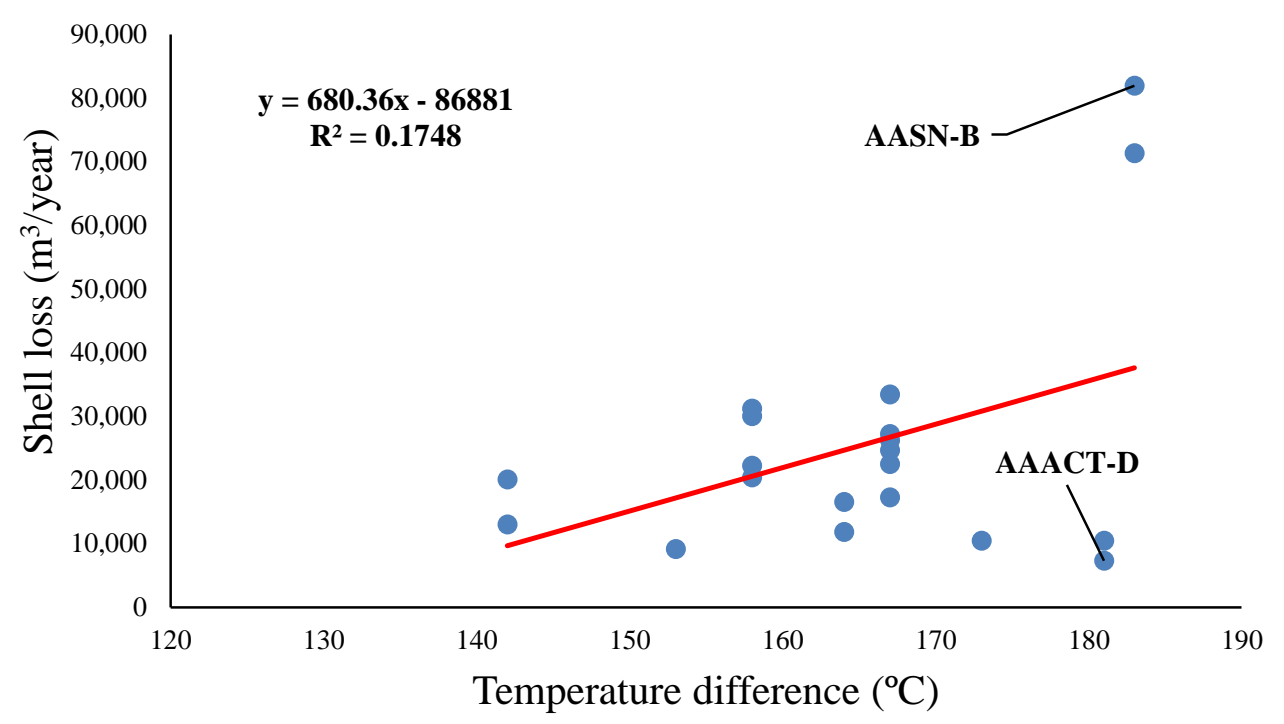

Figure 4.25: Shell loss vs. temperature difference

Figure 4.26 displays shell loss with the ration of temperature difference and overall thermal resistance of oven shell. Analysis shows that AASN-B had the highest, while AAACT-D had the lowest shell loss with the ration of this two variables. Operating temperature difference and thermal resistance are the factors contributed to exhaust loss. Graph shows a shell loss has an increasing trend with the ration of temperature difference and overall thermal resistance. 


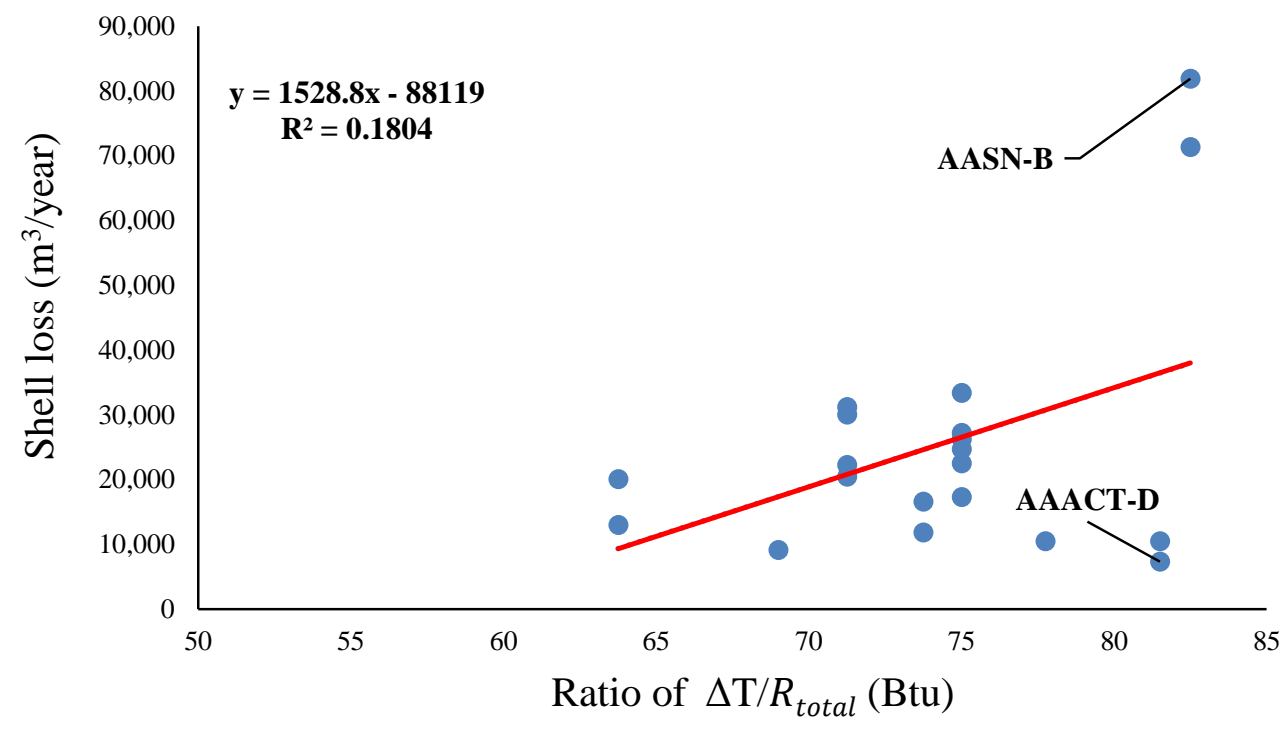

Figure 4.26: Shell loss vs. $\frac{\Delta \mathrm{T}}{R_{\text {total }}}$

Table 4.10: Oven shell loss and oven area

\begin{tabular}{|c|c|c|}
\hline Name of Company & Shell Energy Loss & Oven Envelope Area \\
\hline & $\left(\mathbf{m}^{\mathbf{3} / \text { year })}\right.$ & $\left.\mathbf{( f t}^{\mathbf{}}\right)$ \\
\hline AAGF-B & 71,337 & 5,044 \\
\hline AASN-B & 81,897 & 4,640 \\
\hline AAAL-D & 22,500 & 4,200 \\
\hline AAAL-C & 27,214 & 5,080 \\
\hline AABN-D & 22,259 & 2,680 \\
\hline AABN-C & 31,229 & 3,760 \\
\hline AACF-D & 20,449 & 1,960 \\
\hline AACF-C & 30,047 & 2,880 \\
\hline AAMP-D & 26,229 & 2,040 \\
\hline AAMP-C & 33,429 & 2,600 \\
\hline AAACT-D & 7,335 & 1,400 \\
\hline AAACT-C & 10,479 & 2,000 \\
\hline AASPEC-D & 10,485 & 2,360 \\
\hline AASPEC-C & 9,147 & 2,320 \\
\hline AAWIL-D & 13,027 & 3,576 \\
\hline AAWIL-C & 20,109 & 5,520 \\
\hline D-78-D & 11,834 & 2,808 \\
\hline D-78-C & 16,587 & 3,936 \\
\hline D-225-D & 17,280 & 4,032 \\
\hline D-225-C & 24,686 & 5,760 \\
\hline & & \\
\hline
\end{tabular}


Figure 4.27 displays shell loss vs. oven envelope area. The $\mathrm{R}^{2}$ value was 0.2143 , meaning that the correlation between these parameters is not significantly strong. AASN-B shows the highest shell loss while AAACT-D shows the lowest among others.

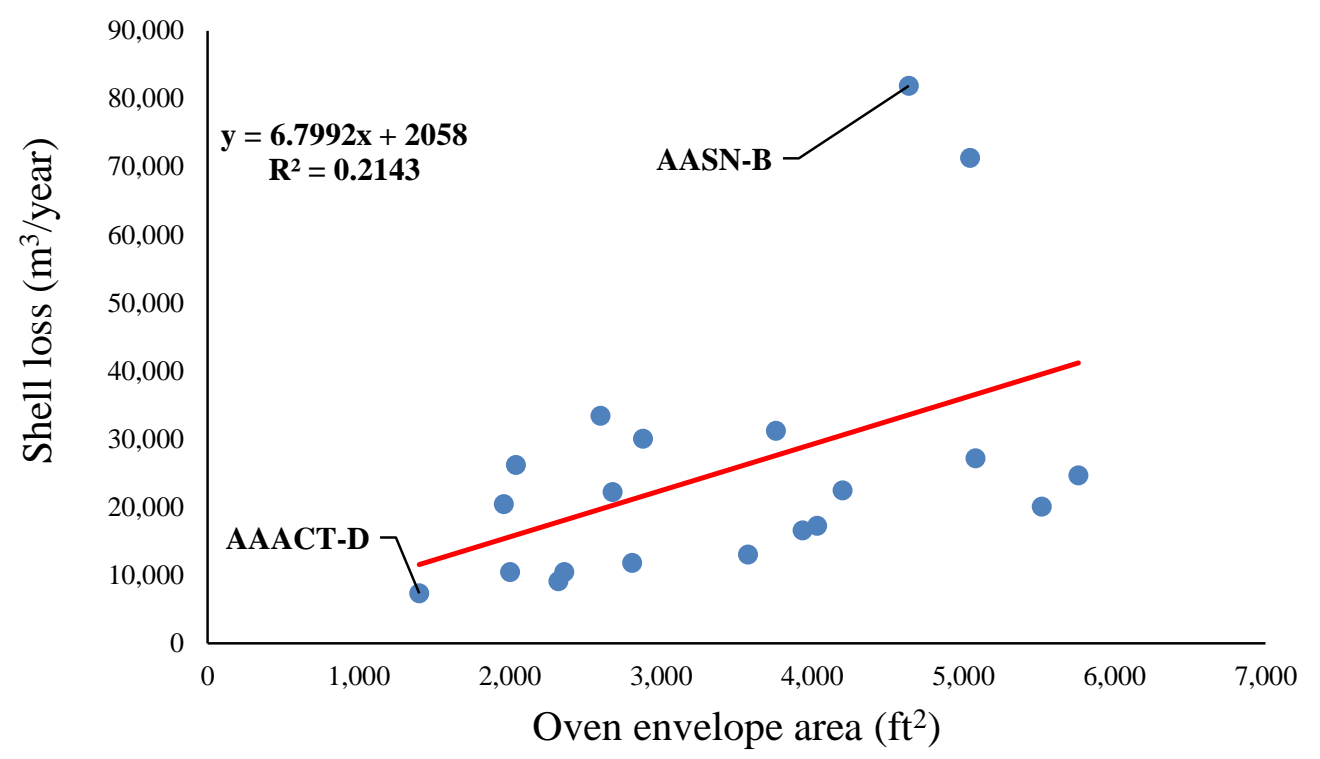

Figure 4.27: Shell loss vs. oven envelope area

\subsection{Radiation Energy Loss Analysis}

Transfer of heat energy to facility space caused energy loss through radiation. Table 4.11 displays radiation heat loss from oven skin. Column 2 shows facility reference temperature, and Column 3 shows the oven skin temperature. Thermal emissivity determined one as an ideal emitter and the Stefen Boltzman constant as 1.714 x 10-9 Btu/hr ft2 R4. The result of radiation loss is presented in Column 6 of Table xxx. The calculations show from $2 \%-4 \%$ oven energy loss through radiation, which is higher than the percentage of miscellaneous heat loss as $1-2 \%$ in George Koch Sons, LLC $[55,56,57]$. This radiation heat loss contributes to higher operating than the standard described by George Koch Sons, LLC. 
Table 4.11: Radiation energy loss from oven

\begin{tabular}{|c|c|c|c|c|c|c|c|c|}
\hline $\begin{array}{l}\text { Company } \\
\text { Name }\end{array}$ & $\begin{array}{c}\text { Facility } \\
\text { Reference } \\
\text { Temperature }\end{array}$ & $\begin{array}{c}\text { Facility } \\
\text { Reference } \\
\text { Temperature }\end{array}$ & $\begin{array}{c}\text { Oven } \\
\text { Skin } \\
\text { Temp }\end{array}$ & $\begin{array}{l}\text { Oven } \\
\text { Skin } \\
\text { Temp }\end{array}$ & $\begin{array}{l}\text { Oven } \\
\text { Area }\end{array}$ & $\begin{array}{c}\text { Operation } \\
\text { Hour }\end{array}$ & $\begin{array}{c}\text { Radiation } \\
\text { Energy } \\
\text { Loss }\end{array}$ & $\begin{array}{l}\text { Radiation } \\
\text { Loss in } \\
\text { Percentage } \\
\text { of Total }\end{array}$ \\
\hline & $\left({ }^{\circ} \mathbf{F}\right)$ & $\left({ }^{\circ} \mathrm{C}\right)$ & $\left({ }^{\circ} \mathbf{F}\right)$ & $\left({ }^{\circ} \mathrm{C}\right)$ & $\left(\mathbf{f t}^{2}\right)$ & (hr/year) & (m³/year) & $(\%)$ \\
\hline AAGF & 70 & 21 & 80 & 27 & 5044 & 6000 & 9062 & 2.79 \\
\hline AASN & 70 & 21 & 80 & 27 & 4640 & 7488 & 10404 & 2.93 \\
\hline AAAL & 70 & 21 & 80 & 27 & 4200 & 2500 & 3144 & 2.62 \\
\hline AABN & 70 & 21 & 80 & 27 & 5080 & 2500 & 3803 & 2.53 \\
\hline AACF & 65 & 18 & 75 & 24 & 2680 & 4080 & 3183 & 2.67 \\
\hline AAMP & 65 & 18 & 75 & 24 & 3760 & 4080 & 4466 & 2.61 \\
\hline AAACT & 70 & 21 & 80 & 27 & 1960 & 5125 & 3008 & 2.78 \\
\hline AASPEC & 70 & 21 & 80 & 27 & 2880 & 5125 & 4420 & 2.71 \\
\hline AAWIL & 70 & 21 & 80 & 27 & 2040 & 6000 & 3665 & 2.84 \\
\hline D-78 & 70 & 21 & 80 & 27 & 2600 & 6000 & 4671 & 2.77 \\
\hline D-225 & 70 & 21 & 80 & 27 & 1400 & 2250 & 943 & 2.22 \\
\hline AAAL & 70 & 21 & 80 & 27 & 2000 & 2250 & 1347 & 2.33 \\
\hline AABN & 69 & 21 & 80 & 27 & 2360 & 2000 & 1550 & 3.92 \\
\hline AACF & 69 & 21 & 80 & 27 & 2320 & 2000 & 1524 & 4.12 \\
\hline AAMP & 65 & 18 & 75 & 24 & 3576 & 2000 & 2082 & 3.05 \\
\hline AAACT & 65 & 18 & 75 & 24 & 5520 & 2000 & 3214 & 3.20 \\
\hline AASPEC & 65 & 18 & 75 & 24 & 2808 & 2000 & 1635 & 2.78 \\
\hline AAWIL & 65 & 18 & 75 & 24 & 3936 & 2000 & 2292 & 2.54 \\
\hline D-78 & 65 & 18 & 75 & 24 & 4032 & 2000 & 2348 & 1.94 \\
\hline D-225 & 65 & 18 & 75 & 24 & 5760 & 2000 & 3354 & 2.38 \\
\hline
\end{tabular}

\subsection{Productive and Non-productive Hours Natural Gas Consumption Analysis}

Productive hours natural gas consumption is defined as the consumption during the hours when a plant is producing [97]. The acronym of the company followed by the letter $\mathrm{F}$ and $\mathrm{P}$, which refer to food and finishing process company in Table 4.12, Column 1. Eleven audited plants run five days per week. The usual weekends are Saturday and Sunday. Plant AASN-F maintain one day, Sunday, as the weekend.

The results of the analysis are presented in Table 4.12. Calculated non-productive hours in a year based on the information from schedule, while non-productive hours energy consumption was 
extracted from daily and hourly utility bill and presented in column 6. Process energy consumption analysis was performed on eleven audited companies. Food companies consumed process energy per unit hour of operation from $65 \mathrm{~m}^{3} / \mathrm{h}$ to $452 \mathrm{~m}^{3} / \mathrm{h}$, and finishing process industries at $12 \mathrm{~m}^{3} / \mathrm{h}$ to $429 \mathrm{~m}^{3} / \mathrm{h}$. These are presented in Table 4.12 . Productive hours index was calculated by total consumption / (plant area x yearly operation hour) and presented in Table 4.12, Column 8. This index indicated energy uses in productive hours.

Table 4.12: Summary of natural gas consumption of productive and non-productive hours

\begin{tabular}{|c|c|c|c|c|c|c|c|c|c|}
\hline 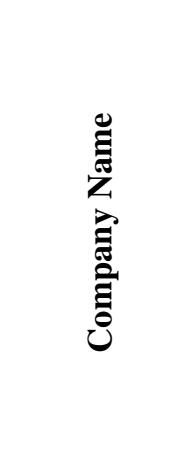 & 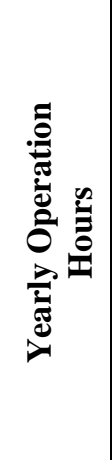 & 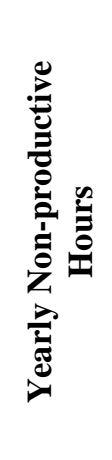 & 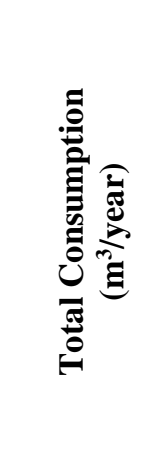 & 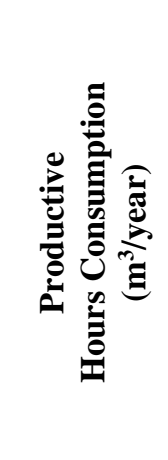 & 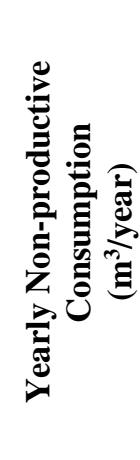 & 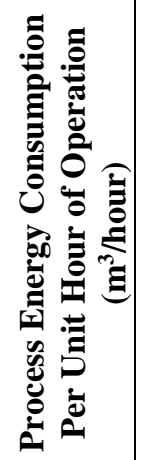 & 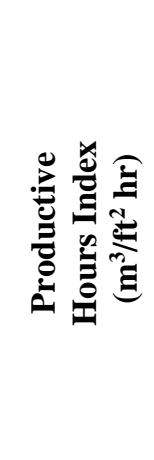 & 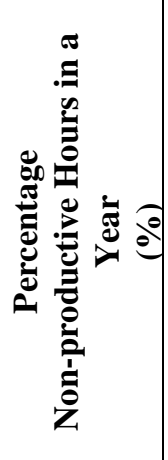 & 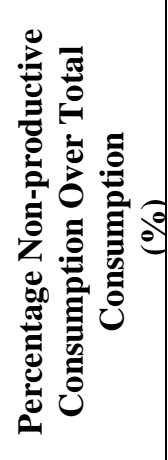 \\
\hline AAGF-F & 6,000 & 2,760 & $3,372,327$ & $2,709,881$ & 662,446 & 452 & $2.99 \mathrm{E}-03$ & 32 & 20 \\
\hline AASN-F & 7,488 & 1,272 & 546,832 & 486,991 & 59,841 & 65 & $3.88 \mathrm{E}-04$ & 15 & 11 \\
\hline AAAL-P & 2,500 & 6,260 & 584,907 & 496,858 & 88,049 & 199 & $3.54 \mathrm{E}-03$ & 71 & 15 \\
\hline AACF-P & 5,125 & 3,635 & 437,383 & 403,590 & 33,793 & 79 & $1.82 \mathrm{E}-03$ & 41 & 8 \\
\hline AAMP-P & 6,000 & 2,760 & 514,025 & 168,437 & 345,588 & 28 & $1.27 \mathrm{E}-03$ & 32 & 67 \\
\hline AABN-P & 4,000 & 4,760 & 363,976 & 112,852 & 251,124 & 28 & $9.25 \mathrm{E}-04$ & 54 & 69 \\
\hline AASPEC-P & 3,000 & 5,760 & 369,364 & 292,628 & 76,736 & 98 & $2.03 \mathrm{E}-03$ & 66 & 21 \\
\hline AAWIL-P & 2,000 & 6,760 & 298,809 & 110,973 & 187,836 & 55 & $1.35 \mathrm{E}-03$ & 77 & 63 \\
\hline D-78-P & 2,000 & 6,760 & 951,907 & 761,011 & 190,896 & 381 & $2.07 \mathrm{E}-03$ & 77 & 20 \\
\hline D-225-P & 2,000 & 6,760 & $1,306,121$ & 857,813 & 448,308 & 429 & $3.06 \mathrm{E}-03$ & 77 & 34 \\
\hline AAACT-P & 2,250 & 6,510 & 161,682 & 27,366 & 134,316 & 12 & $6.96 \mathrm{E}-03$ & 74 & 83 \\
\hline
\end{tabular}

Figure 4.28 shows the upper and lower limits of two types of audited companies. Process energy consumption analysis was performed to draw significant upper and lower limits or range of process energy consumption for similar types of companies. Among these eleven companies, food companies have a lower limit of $65 \mathrm{~m}^{3} / \mathrm{hr}$ and upper limit of $452 \mathrm{~m}^{3} / \mathrm{hr}$, AASN and AAGF 
respectively. Finishing process industries have a lower limit of $12 \mathrm{~m}^{3} / \mathrm{hr}$ and upper limit of $429 \mathrm{~m}^{3} / \mathrm{hr}$, AAACT and D-225 respectively. Company AAACT has the lowest consumption while AAGF has the highest energy consumption based on process energy consumption per hour.

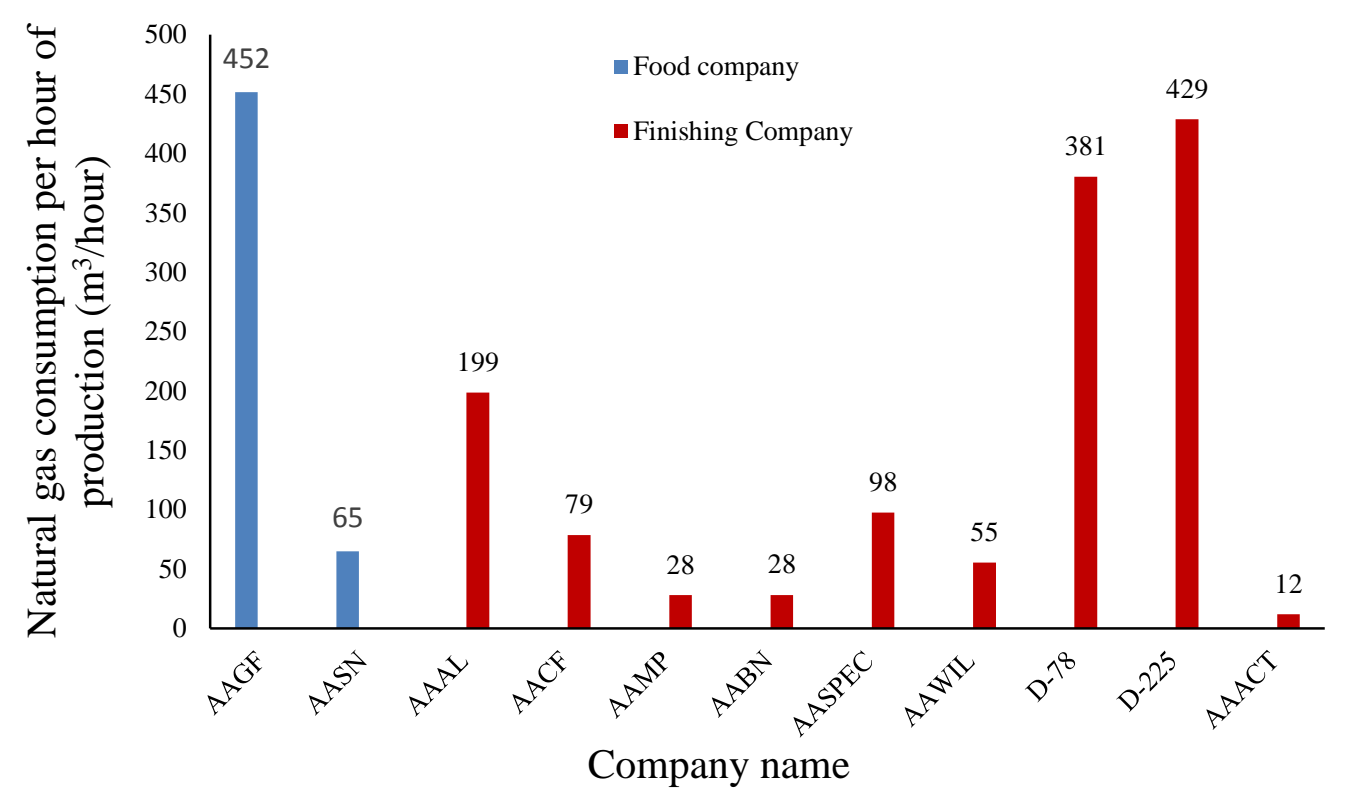

Figure 4.28: Natural gas consumption per hour of production of audited companies

Figure 4.29 displays the energy consumption index for productive hours. The productive hours consumption index was calculated as the ratio of productive hours consumption and the product of facility area and number of productive hours. 


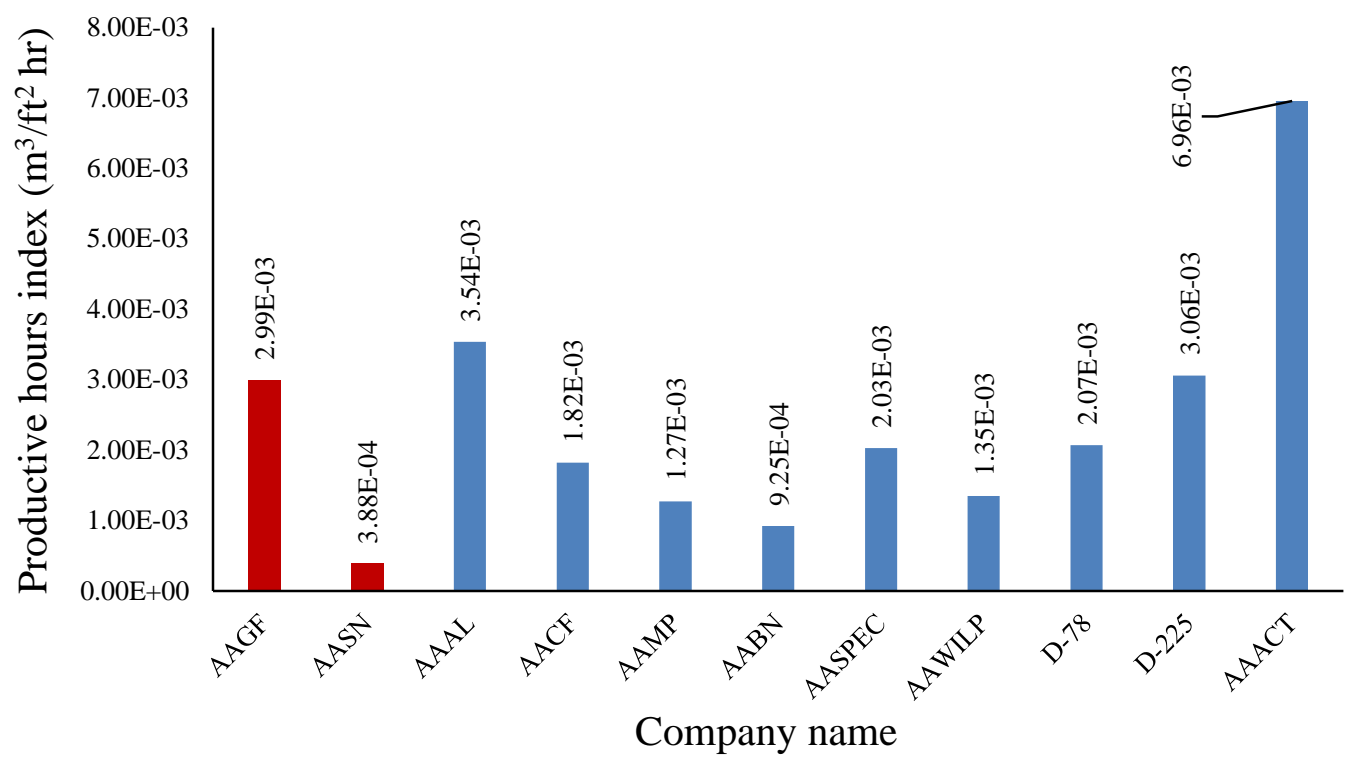

Figure 4.29: Productive hours energy consumption index

The finishing process industries show a decreasing trend with the increase of plant area. No conclusion can be drawn about the food companies because of limited data (only two companies). AAACT-P shows the highest productive hours index while AABN-P shows the lowest among finishing companies.

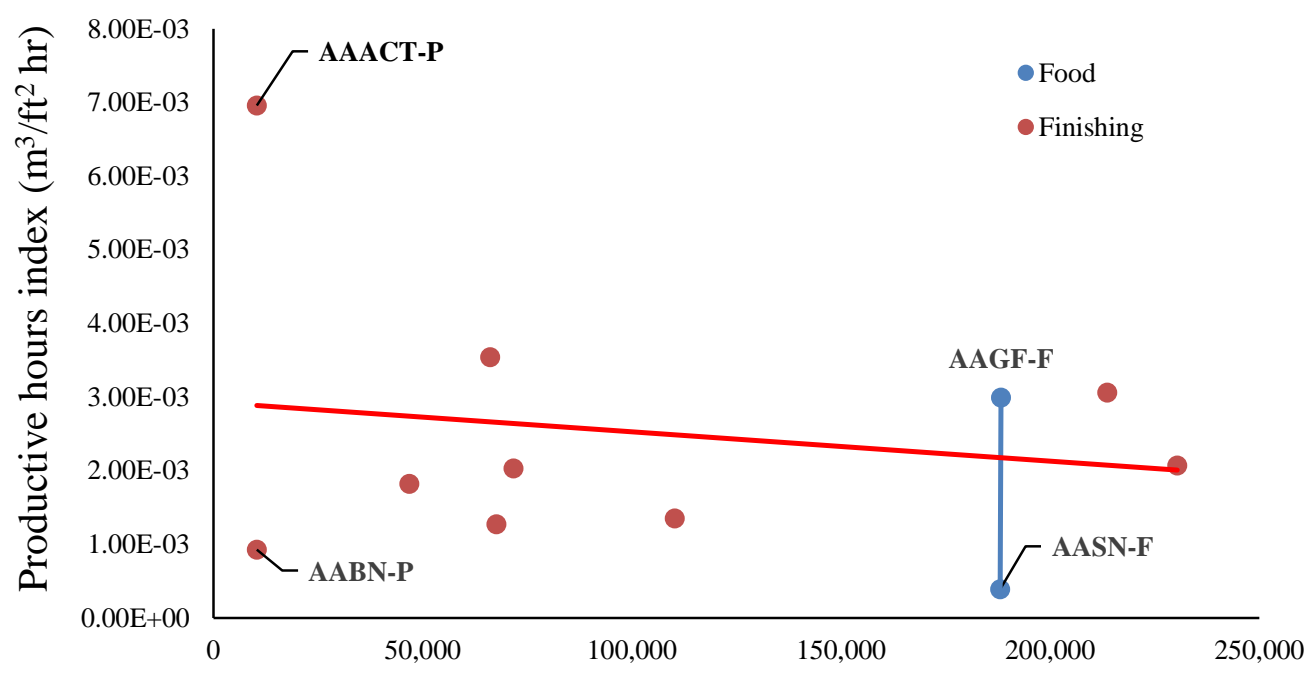

Facility area $\left(\mathrm{ft}^{2}\right)$

Figure 4.30: Productive index of process energy of the audited plants 
Table 4.13 shows the percentage of natural gas consumption for production. The lower limit was close to $17 \%$ and the upper limit was $92 \%$.

To maintain indoor quality some of the heating and ventilation equipment were left running during non-productive hours which contributed non-productive hours energy consumption. It is assumed that only the required equipment were running during non-productive times. Column 3 , Table 4.13 shows that AAACT has opportunity to improve percentage of productive time's consumption.

Table 4.13: Productive time's consumption as a percentage of total annual consumption

\begin{tabular}{|c|c|c|}
\hline Company Name & Type of Company & $\begin{array}{c}\text { Natural Gas Consumption } \\
\text { of Productive Hours } \\
\text { Consumption as a Percentage of } \\
\text { Total Consumption } \\
(\boldsymbol{\%})\end{array}$ \\
\hline AAGF & Food & 80 \\
\hline AASN & Food & 89 \\
\hline AAAL & Finishing & 85 \\
\hline AACF & Finishing & 92 \\
\hline AAMP & Finishing & 33 \\
\hline AABN & Finishing & 31 \\
\hline AASPEC & Finishing & 79 \\
\hline AAWIL & Finishing & 37 \\
\hline D-78 & Finishing & 60 \\
\hline D-225 & Finishing & 17 \\
\hline AAACT & Finishing & 66 \\
\hline
\end{tabular}

Figure 4.31 presents percent natural gas consumption during productive hours at audited companies. The percent productive hours energy consumption of total plant's consumption of all the audited companies was found to be between $17 \%$ to $92 \%$. The higher percent energy consumption signifies that most of the energy is used for production. Company AAACT had the 
lowest natural gas consumption during productive hours while company AACF had the highest natural gas consumption.

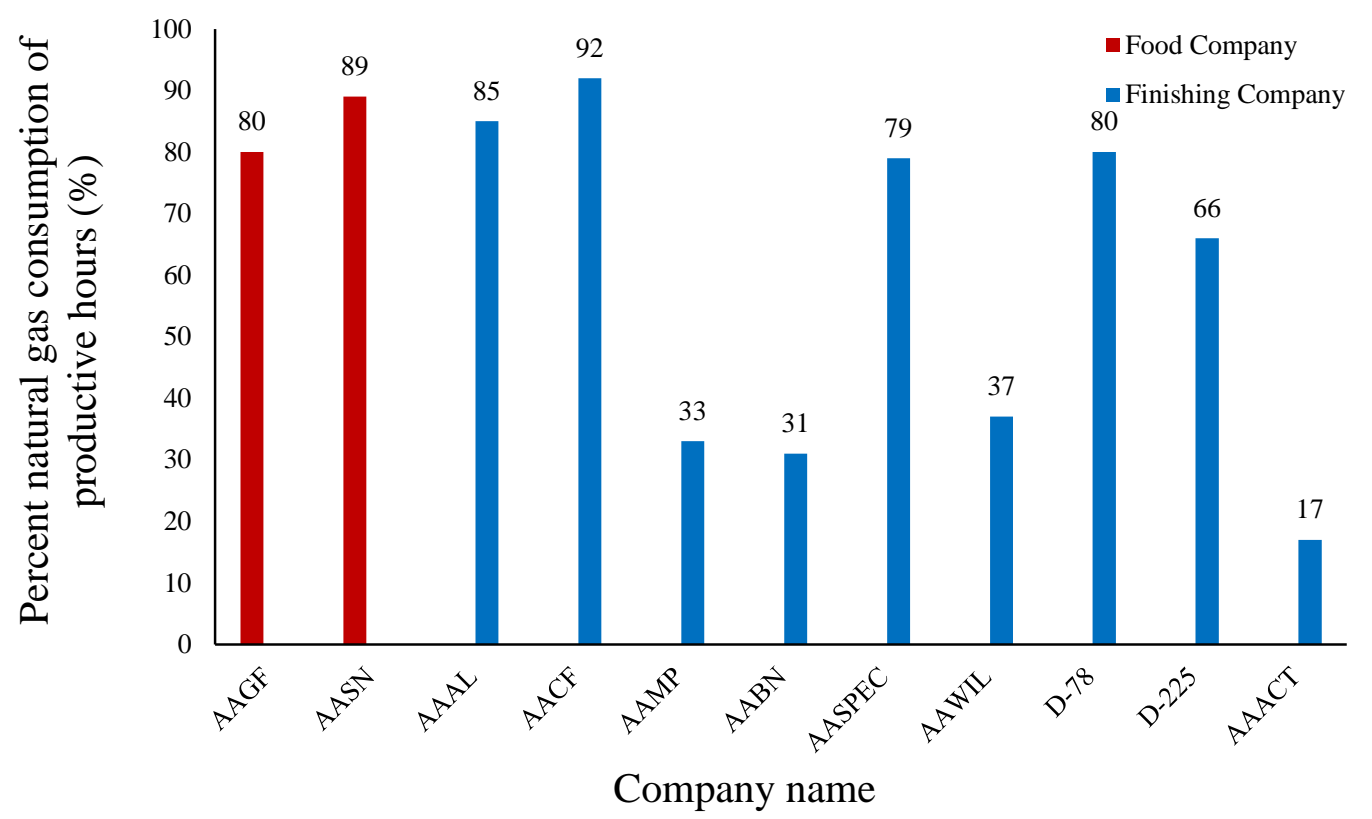

Figure 4.31: Percent natural gas consumption of productive hours

\subsection{Non-Productive Hours Energy Consumption Analysis}

Reduction of misuse and loss can improve energy consumption per unit of production. Therefore, identifying areas of misuse and loss is an important step in creating an energyefficient plant.

An analysis was performed, on energy consumption during non-productive hours, to investigate potential savings in the natural gas consumption of industrial plants. Non-productive hours include scheduled weekends [103, 104], declared statutory holidays in Ontario [103, 104], and scheduled annual shut-down periods. Daily and hourly utility consumption data were used in the analysis of energy consumption during non-productive hours. The analysis was necessary 
because it was suspected that plant machinery was running idly during non-operational hours, which eventually led to energy loss.

Table 4.14 displays percentage non-productive hours and non-productive consumption. These analysis were performed to estimate energy consumption in non-productive times over the total consumption and total year. This analysis shows that AABN-P has an opportunity to reduce nonproductive hours consumption while D-78-P, AAWIL-P, and D-225-P has an opportunity to reduce non-productive hours.

Table 4.14: Percentage non-productive hours and non-productive consumption

\begin{tabular}{|c|c|c|}
\hline Company name & $\begin{array}{c}\text { Percentage of } \\
\text { Non-productive Hours } \\
\text { Over Total Hours in a } \\
\text { Year }\end{array}$ & $\begin{array}{c}\text { Percentage Non-productive } \\
\text { Consumption Over Total } \\
\text { Consumption }\end{array}$ \\
\cline { 2 - 3 } & $\mathbf{( \% )}$ & $\mathbf{( \% )}$ \\
\hline AAGF-F & 32 & 20 \\
\hline AASN-F & 15 & 11 \\
\hline AAAL-P & 71 & 15 \\
\hline AACF-P & 41 & 8 \\
\hline AAMP-P & 32 & 67 \\
\hline AABN-P & 54 & 21 \\
\hline AASPEC-P & 66 & 63 \\
\hline AAWIL-P & 77 & 20 \\
\hline D-78-P & 77 & 34 \\
\hline D-225-P & 77 & 83 \\
\hline AAACT-P & 74 & 69 \\
\hline
\end{tabular}

To determine how much energy was consumed during non-productive hours, daily and hourly consumption data were analyzed. The yearly average non-productive hours and corresponding consumption were obtained by summing up the consumption data for the weekends of billings years, and consumption during non-productive hours. The percentage of non-productive hours over annual hours was calculated. The resulting energy consumption during non-productive 
hours over annual consumption was calculated and plotted on the $\mathrm{X}$-axis and $\mathrm{Y}$-axis respectively. A graph is drawn considering ideal situation where $\mathrm{R}^{2}$ value assumed 1, shows black in Figure 4.32. Plants shows above the ideal line represents inefficient while plants are below the trend line are efficient plants.

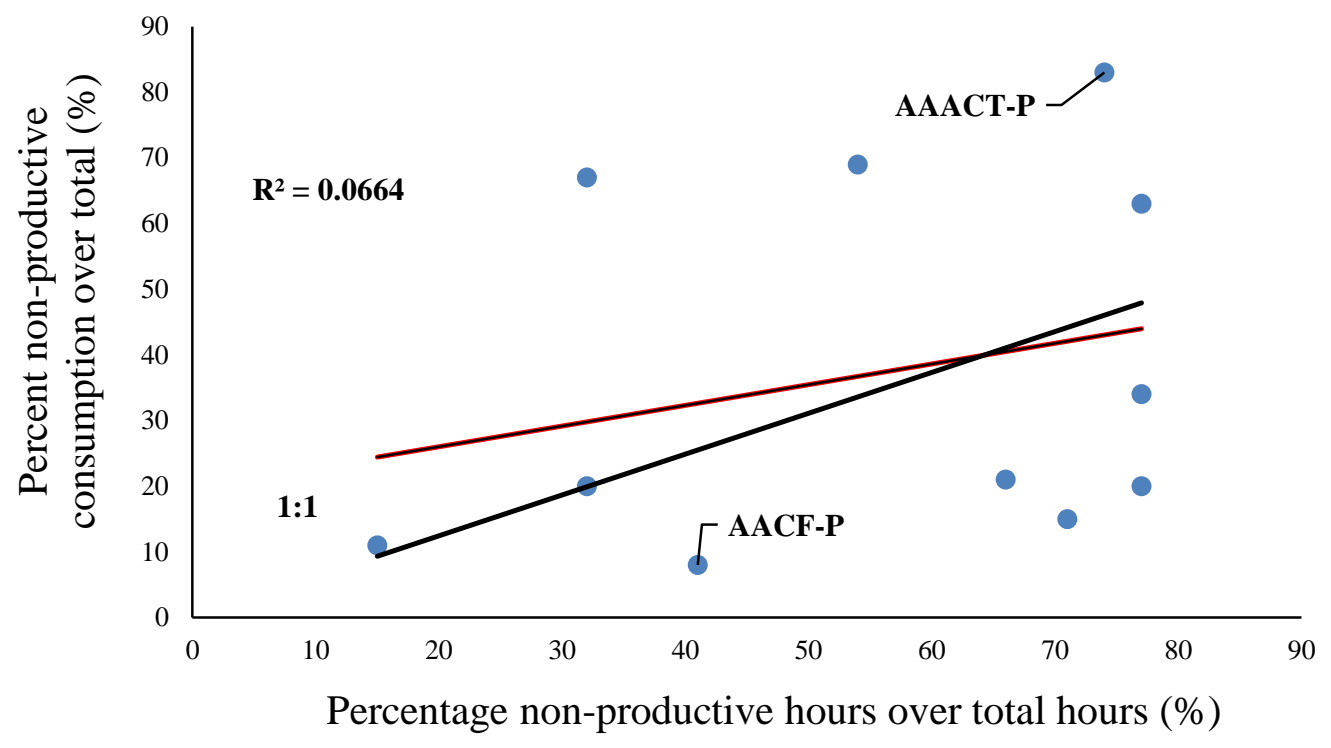

Figure 4.32: Energy consumption during non-productive hours

\subsection{Non-Productive Hours Energy Consumption Analysis Based on Summer Months}

An analysis was performed on energy consumption during non-productive hours based on summer months to investigate potential savings and in natural gas consumption of industrial plants. Heating and ventilation units are not usually working during summer months. Therefore a clear non-productive hour's loss can be estimated without natural gas consumption to maintain indoor air quality. The summer months (June, July, August) consumption, productive hours, nonproductive hours, percentage non-productive consumption over total, and percentage nonproductive hours over productive are presented in Table 4.15. Column 2 shows the non- 
productive hours consumption, column 3 shows productive hours consumption, column 5 shows non-productive hours, and column 6 shows productive hours during the summer months.

Study shows that AAGF-F has an opportunity to reduce non-productive hour's consumption, while AAWIL-P, D-78-P, and D-225-P have the opportunity to reduce non-productive hours in their schedule.

Table 4.15: Productive and non-productive hours consumption analysis (summer months)

\begin{tabular}{|c|c|c|c|c|c|c|c|}
\hline 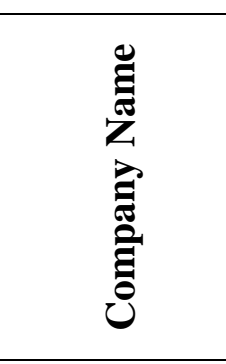 & 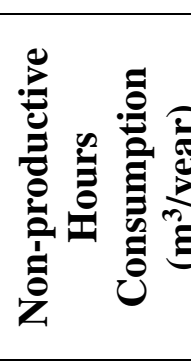 & 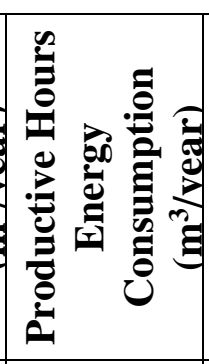 & 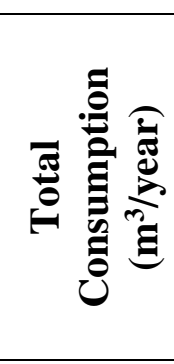 & 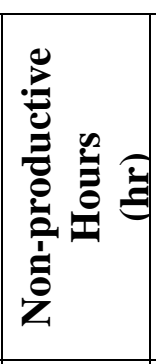 & 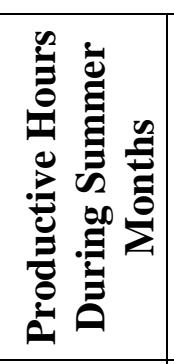 & 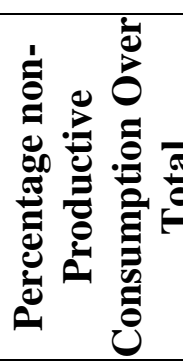 & 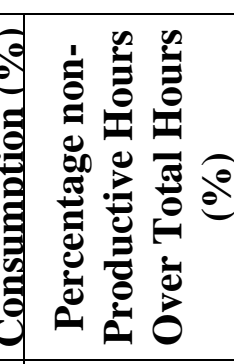 \\
\hline AAGF-F & 131,281 & 432,802 & 564,083 & 576 & 1,440 & 23.27 & 27 \\
\hline AASN-F & 13,563 & 107,418 & 120,981 & 288 & 1,728 & 11.21 & 13 \\
\hline AAAL-P & 11,884 & 104,518 & 116,402 & 816 & 1,200 & 10.21 & 38 \\
\hline AACF-P & 2,150 & 98,748 & 100,898 & 786 & 1,230 & 2.13 & 36 \\
\hline AAMP-P & 12,632 & 73,765 & 86,397 & 576 & 1,440 & 14.62 & 27 \\
\hline AABN-P & 96 & 62,685 & 62,781 & 1,056 & 960 & 0.15 & 49 \\
\hline AASPEC-P & 5,635 & 41,324 & 46,959 & 1,296 & 720 & 12.00 & 60 \\
\hline AAWIL-P & 5,567 & 41,392 & 46,959 & 1,536 & 480 & 11.86 & 71 \\
\hline D-78-P & 4,964 & 42,760 & 47,724 & 1,536 & 480 & 10.40 & 71 \\
\hline D-225-P & 2,112 & 17,072 & 19,184 & 1,536 & 480 & 11.01 & 71 \\
\hline AAACT-P & 3,245 & 30,334 & 33,579 & 1,476 & 540 & 9.66 & 68 \\
\hline
\end{tabular}

Figure 4.33 shows different than Figure 4.32 though the same concept applied in both cases. Study observed that in the summer months non-productive hours consumption less than when this was considered for the total year. At the same time non-productive hours observed less in summer months. 


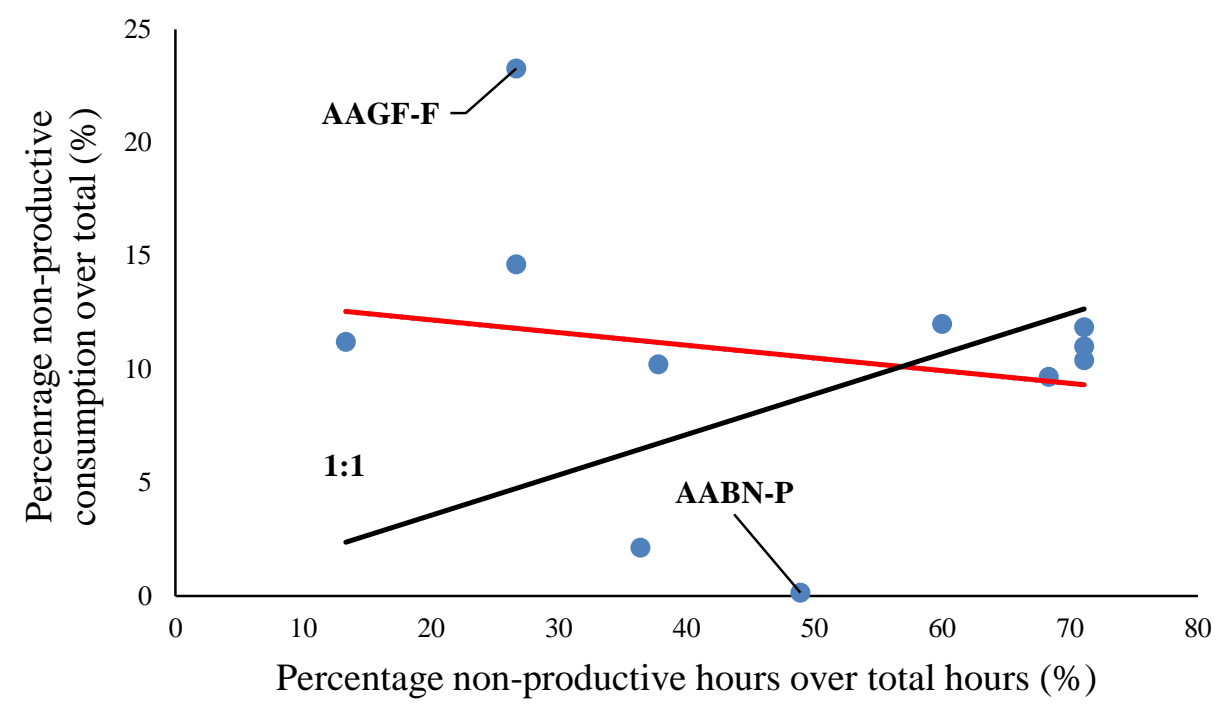

Figure 4.33: Energy consumption during non-productive hours (summer months average)

Scattered points in the non-productive hours energy consumption show that the percentage of non-productive hours are not the same for all the plants. This percentage depends on facility area, hours of operation, and product type. Non-productive hours consumption signifies that the machines are ideally running during non-productive hours. Therefore, different plans have different non-productive hours consumption, which is the cause of stray points on the graph. If the non-productive hours consumption can be reduced, then operating cost can be reduced a significant amount. On the other hand, there is a decreasing trend during the summer months when the out production is more. When the gap between production output and the scope of nonproductive hours consumption is reduced, operating equipment has a smaller scope of slackness or tardiness. 


\subsection{Savings Analysis}

Energy costs are important in industrial sectors like bakery and finishing process industries. This study revealed that major energy losses are caused by the ovens' exhaust. Savings could be achieved by reducing ovens exhaust; however, the exhaust flow rate should not be decreased below that required for safe operation of oven. For this purpose, the exhaust requirement methodology presented by Enbridge Gas Distribution Inc. [55, 56, 57] could be used to determine the flow rate for safe operation.

\subsubsection{Energy Savings from Oven Exhaust}

The study showed that companies operated their oven exhaust fans continuously and at high velocities even when they were not required. It is important to operate exhaust fans at the appropriate velocity only when it is necessary.

Exhaust flow is an important criterion for determining the operational safety of an oven. Better control of exhaust fans can save costs in terms of operating electricity and heated air. The percent savings from operating exhaust are presented in Table 4.16, column 7. It can be seen that exhaust savings can range from $19 \%$ to $53 \%$ depending on the size, exhaust CFM, operating temperature, and production type. 
Table 4.16: Exhaust requirements and current exhaust of ovens

\begin{tabular}{|c|c|c|c|c|c|c|}
\hline 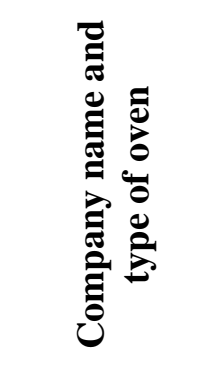 & 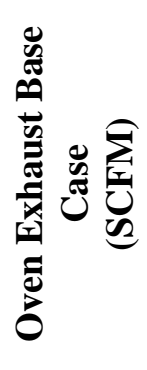 & 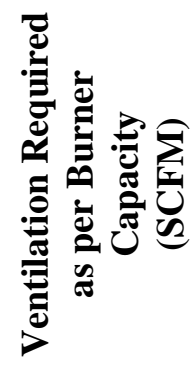 & 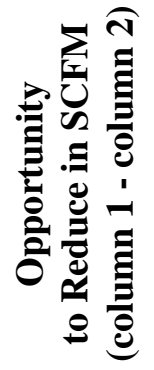 & 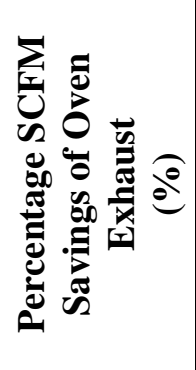 & 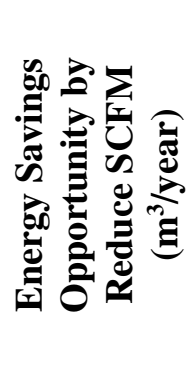 & 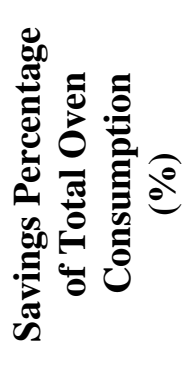 \\
\hline AAGF-B & 3,380 & 549 & 2,831 & 84 & 172,966 & 53 \\
\hline AASN-B & 3,000 & 549 & 2,451 & 82 & 186,887 & 53 \\
\hline AAAL-D & 2,500 & 641 & 1,859 & 74 & 43,023 & 36 \\
\hline AAAL-C & 3,300 & 824 & 2,476 & 75 & 79,764 & 53 \\
\hline AABN-D & 1,200 & 275 & 925 & 77 & 29,696 & 25 \\
\hline AABN-C & 2,400 & 641 & 1,759 & 73 & 52,041 & 30 \\
\hline AACF-D & 1,000 & 275 & 725 & 73 & 30,956 & 29 \\
\hline AACF-C & 1,800 & 549 & 1,251 & 70 & 49,459 & 30 \\
\hline AAMP-D & 900 & 183 & 717 & 80 & 39,824 & 31 \\
\hline AAMP-C & 1,500 & 549 & 951 & 63 & 47,539 & 28 \\
\hline AAACT-D & 600 & 183 & 417 & 70 & 8,106 & 19 \\
\hline AAACT-C & 1,200 & 366 & 834 & 70 & 15,055 & 26 \\
\hline AASPEC-D & 928 & 275 & 653 & 70 & 12,493 & 32 \\
\hline AASPEC-C & 950 & 366 & 584 & 61 & 9,991 & 27 \\
\hline AAWIL-D & 1,620 & 458 & 1,162 & 72 & 19,004 & 28 \\
\hline AAWIL-C & 3,600 & 1,098 & 2,502 & 70 & 39,374 & 39 \\
\hline D-78-D & 1,260 & 183 & 1,077 & 85 & 19,608 & 33 \\
\hline D-78-C & 2,520 & 275 & 2,245 & 89 & 38,101 & 42 \\
\hline D-225-D & 2,304 & 549 & 1,755 & 76 & 32,493 & 27 \\
\hline D-225-C & 4,608 & 1,098 & 3,510 & 76 & 61,736 & 44 \\
\hline
\end{tabular}

\subsubsection{Energy Savings Opportunity from Oven Shell Energy Loss Through Improving Insulation Thermal Resistance (R)}

This research observed that $10 \%$ to $31 \%$ of oven consumption was lost through the oven shell. This can be remedied with the internal and external surface of the oven and the insulation condition of the shell. In this research the loss factor is considered as a flat value as $0.25 \%$, (estimated U value and estimated average panel thickness 6 inch) [57] which can be changed based on the "R" value. On the one hand, the internal surface reflectivity can reduce absorption of heat by the shell plates and increase internal air heating. On the other hand, the $\mathrm{R}$ value can 
affect heat conduction through shell plates. A simulated value calculated using different percentage of reduced loss factors and presented in Table 4.17. In the same table presents actual energy loss through the shell with its current estimated configuration. From columns 3 to 7 , the simulated values are based on $10 \%$ reduction of loss factor from base case.

Table 4.17: Shell energy loss of ovens with different loss factors

\begin{tabular}{|c|c|c|c|c|c|c|}
\hline 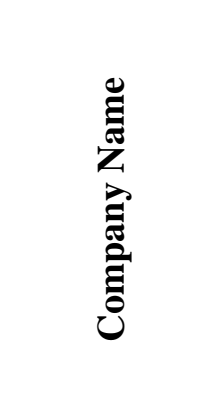 & 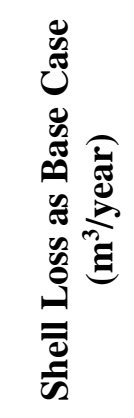 & 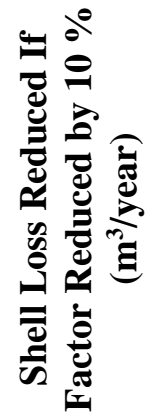 & 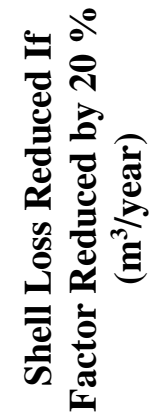 & 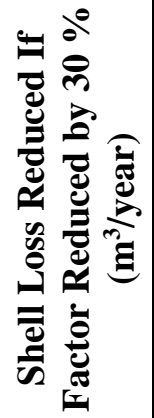 & 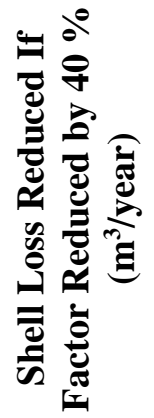 & 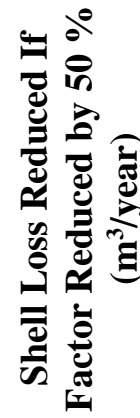 \\
\hline AAGF-B & 71,337 & 64,203 & 57,069 & 49,936 & 42,802 & 35,668 \\
\hline AASN-B & 81,897 & 73,708 & 65,518 & 57,328 & 49,138 & 40,949 \\
\hline AAAL-D & 22,500 & 20,250 & 18,000 & 15,750 & 13,500 & 11,250 \\
\hline AABN-D & 27,214 & 24,493 & 21,771 & 19,050 & 16,329 & 13,607 \\
\hline AACF-D & 22,259 & 20,033 & 17,807 & 15,582 & 13,356 & 11,130 \\
\hline AAMP-D & 31,229 & 28,107 & 24,984 & 21,861 & 18,738 & 15,615 \\
\hline AAACT-D & 20,449 & 18,404 & 16,359 & 14,314 & 12,269 & 10,224 \\
\hline AASPEC-D & 30,047 & 27,042 & 24,038 & 21,033 & 18,028 & 15,024 \\
\hline AAWIL-D & 26,229 & 23,606 & 20,983 & 18,360 & 15,737 & 13,114 \\
\hline D-78-D & 33,429 & 30,086 & 26,743 & 23,400 & 20,057 & 16,714 \\
\hline D-225-D & 7,335 & 6,602 & 5,868 & 5,135 & 4,401 & 3,668 \\
\hline AAAL-C & 10,479 & 9,431 & 8,383 & 7,335 & 6,287 & 5,239 \\
\hline AABN-C & 10,485 & 9,437 & 8,388 & 7,340 & 6,291 & 5,243 \\
\hline AACF-C & 9,147 & 8,233 & 7,318 & 6,403 & 5,488 & 4,574 \\
\hline AAMP-C & 13,027 & 11,724 & 10,421 & 9,119 & 7,816 & 6,513 \\
\hline AAACT-C & 20,109 & 18,098 & 16,087 & 14,076 & 12,065 & 10,054 \\
\hline AASPEC-C & 11,834 & 10,650 & 9,467 & 8,284 & 7,100 & 5,917 \\
\hline AAWIL-C & 16,587 & 14,929 & 13,270 & 11,611 & 9,952 & 8,294 \\
\hline D-78-C & 17,280 & 15,552 & 13,824 & 12,096 & 10,368 & 8,640 \\
\hline D-225-C & 24,686 & 22,217 & 19,749 & 17,280 & 14,811 & 12,343 \\
\hline
\end{tabular}


Suitable insulation material of appropriate thickness can minimize heat loss. Shell loss calculated based on estimated loss factor. Considering that shell loss, thermal insulation values were calculated and found similar.

\subsubsection{Exhaust Savings and Estimated Cost Savings Through Retrofits (Installation of VFD)}

Research found that exhaust loss from ovens accounted for $33 \%$ to $64 \%$ in the audited companies, of which $61 \%$ to $89 \%$ can be reduced by maintaining the minimum requirement. This research finding was developed to minimize possible fires and other risks. Therefore, after maintaining the ventilation requirement, energy savings potential was observed in the audited companies. Potential energy savings in different simulated situations are presented in Table 4.18. Table 4.17 shows the different percentages of savings to be gained through the installation of a variable frequency drive (VFD) fan in the air inlet (oxygen) system of ovens, which can be controlled by exhaust mixture properties [100].

The estimated cost involved to install one VFD system in an oven is:

Price of one VFD $($ Capital cost $)=\$ 3,857.12$ plus HST $(@ 13 \%)=\$ 4,358.55$

Labour cost $=\$ 520.00$ (@ $\$ 65$ per hour and estimated 8 hrs $)$

Other material costs $=\$ 200.00$

Total cost to install one VFD $=\$ 5,078.55$

The primary function of VFDs is to vary the speed of a three-phase AC induction motor. This piece of equipment also provides non-emergency start and stop control, acceleration and deceleration, and overload protection. This device also reduces motor start-up rush current by accelerating the motor gradually. For this reason, VFDs are suitable for devices where variable speed is required. 
Selection of VFDs is based on the operating profile of the load it will drive. The choice also depends on constant or variable motor speed run by the VFD, frequency of start and stop of motor, and whether the motor runs continuously. Another major selection criterion will be the maximum current requirement of the motor at peak torque demand. In the current market VFD of required SCFM reduction rating could be difficult to arrange, therefore a simulated cost saving showed in different percentages in Table 4.18.

Table 4.18: Exhaust savings from different percentages of exhaust reduction

\begin{tabular}{|c|c|c|c|c|c|c|c|}
\hline \multirow{2}{*}{ 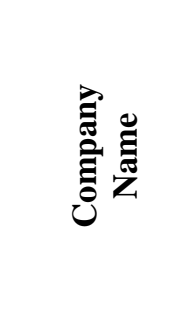 } & \multirow{2}{*}{ 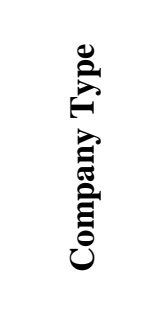 } & \multirow{2}{*}{ 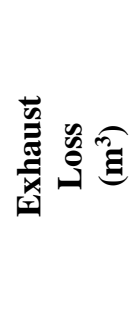 } & \multirow{2}{*}{ 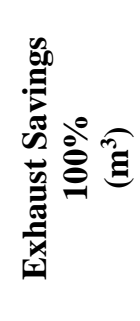 } & \multicolumn{4}{|c|}{ 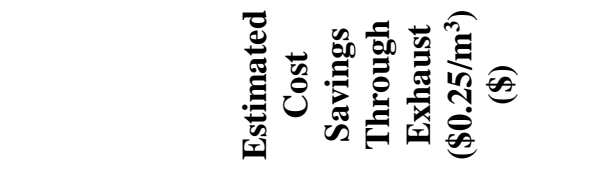 } \\
\hline & & & & $\stackrel{\stackrel{\circ}{\varrho}}{\theta}$ & $\begin{array}{l}\text { of } \\
\text { in }\end{array}$ & $\stackrel{\circ}{\ddot{n}}$ & $\begin{array}{l}\stackrel{0}{0} \\
\stackrel{n}{N}\end{array}$ \\
\hline AAGF-B & \multirow{2}{*}{ Food } & 206,508 & 172,966 & 43,242 & 32,431 & 21,621 & 10,810 \\
\hline AASN-B & & 228,748 & 186,887 & 46,722 & 35,041 & 23,361 & 11,680 \\
\hline AAAL-D & \multirow{18}{*}{ Finishing } & 57,857 & 43,023 & 10,756 & 8,067 & 5,378 & 2,689 \\
\hline AAAL-C & & 76,371 & 79,764 & 19,941 & 14,956 & 9,970 & 4,985 \\
\hline AABN-D & & 43,057 & 29,696 & 7,424 & 5,568 & 3,712 & 1,856 \\
\hline AABN-C & & 86,114 & 52,041 & 13,010 & 9,758 & 6,505 & 3,253 \\
\hline AACF-D & & 45,071 & 30,956 & 7,739 & 5,804 & 3,870 & 1,935 \\
\hline AACF-C & & 81,127 & 49,459 & 12,365 & 9,274 & 6,182 & 3,091 \\
\hline AAMP-D & & 49,989 & 39,824 & 9,956 & 7,467 & 4,978 & 2,489 \\
\hline AAMP-C & & 83,314 & 47,539 & 11,885 & 8,914 & 5,942 & 2,971 \\
\hline AAACT-D & & 13,580 & 8,106 & 2,027 & 1,520 & 1,013 & 507 \\
\hline AAACT-C & & 27,160 & 15,055 & 3,764 & 2,823 & 1,882 & 941 \\
\hline AASPEC-D & & 17,811 & 12,493 & 3,123 & 2,342 & 1,562 & 781 \\
\hline AASPEC-C & & 16,181 & 9,911 & 2,478 & 1,858 & 1,239 & 619 \\
\hline AAWIL-D & & 25,494 & 19,004 & 4,751 & 3,563 & 2,375 & 1,188 \\
\hline AAWIL-C & & 56,654 & 39,374 & 9,844 & 7,383 & 4,922 & 2,461 \\
\hline D-78-D & & 22,939 & 19,608 & 4,902 & 3,676 & 2,451 & 1,225 \\
\hline D-78-C & & 45,878 & 38,101 & 9,525 & 7,144 & 4,763 & 2,381 \\
\hline D-225-D & & 42,657 & 32,493 & 8,123 & 6,092 & 4,062 & 2,031 \\
\hline D-225-C & & 85,314 & 61,736 & 15,434 & 11,575 & 7,717 & 3,858 \\
\hline
\end{tabular}


Table 4.19 displays the percentage savings and payback analysis. Column 2, Table 4.19 shows the cost of installation of VFD, while on the subsequent column from 3 to column 6 shows simulated payback periods with $100 \%, 75 \%, 50 \%$ and $25 \%$ savings respectively. The natural gas billing rate was considered as $0.25 / \mathrm{m}^{3}$. This rate was considered as flat rate to estimate payback analysis. This rate was based on the flat rate of billing for commercial and industrial usages years 2014.

Table 4.19: Percentage savings and payback period

\begin{tabular}{|c|c|c|c|c|c|}
\hline & & & & \\
& & & & \\
& & & & & \\
& & & & & \\
\hline AAGF-B & 5,079 & 0.12 & 0.16 & 0.23 & 0.47 \\
\hline AASN-B & 5,079 & 0.11 & 0.14 & 0.22 & 0.43 \\
\hline AAAL-D & 5,079 & 0.47 & 0.63 & 0.94 & 1.89 \\
\hline AAAL-C & 5,079 & 0.25 & 0.34 & 0.51 & 1.02 \\
\hline AACF-D & 5,079 & 0.68 & 0.91 & 1.37 & 2.74 \\
\hline AACF-C & 5,079 & 0.39 & 0.52 & 0.78 & 1.56 \\
\hline AAMP-D & 5,079 & 0.66 & 0.88 & 1.31 & 2.62 \\
\hline AAMP-C & 5,079 & 0.41 & 0.55 & 0.82 & 1.64 \\
\hline AABN-D & 5,079 & 0.51 & 0.68 & 1.02 & 2.04 \\
\hline AABN-C & 5,079 & 0.43 & 0.57 & 0.85 & 1.71 \\
\hline AASPEC-D & 5,079 & 2.51 & 3.34 & 5.01 & 10.02 \\
\hline AASPEC-C & 5,079 & 1.35 & 1.80 & 2.70 & 5.40 \\
\hline AAWIL-D & 5,079 & 1.63 & 2.17 & 3.25 & 6.50 \\
\hline AAWIL-C & 5,079 & 2.05 & 2.73 & 4.10 & 8.21 \\
\hline D-78-D & 5,079 & 1.07 & 1.43 & 2.14 & 4.28 \\
\hline D-78-C & 5,079 & 0.52 & 0.69 & 1.03 & 2.06 \\
\hline D-225-D & 5,079 & 1.04 & 1.38 & 2.07 & 4.15 \\
\hline D-225-C & 5,079 & 0.53 & 0.71 & 1.07 & 2.13 \\
\hline AAACT-D & 5,079 & 0.63 & 0.83 & 1.25 & 2.50 \\
\hline AAACT-C & 5,079 & 0.33 & 0.44 & 0.66 & 1.32 \\
\hline
\end{tabular}

\subsubsection{Cost Savings Analysis from Shell Energy Loss}

This study investigated how the insulation R value affects energy savings. Calculated energy loss is displayed in Table 4.17, column 2 while other simulated energy losses presented from column 
3 to 9 are based on different $R$ values. The same loss can be reduced with adding more insulation on oven shell envelope. Table 4.20 presents another simulated savings in terms of cost and represent from column 2 to 7 based on the simulated energy savings. According to the data, energy savings through shell envelope loss have the most significant effect on optimizing the thermal insulation $\mathrm{R}$ value.

Table 4.20: Amount of energy savings with reduced oven envelope loss factors

\begin{tabular}{|c|c|c|c|c|c|}
\hline 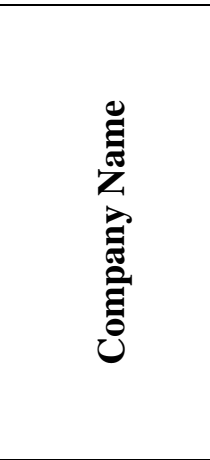 & 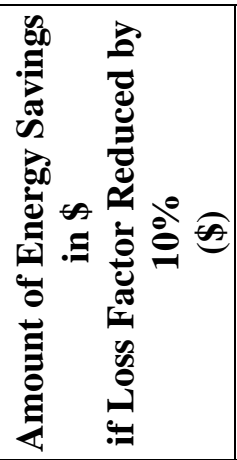 & 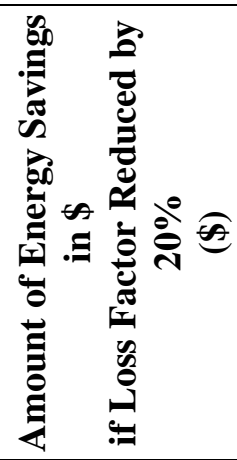 & 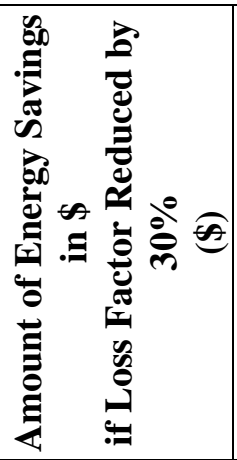 & 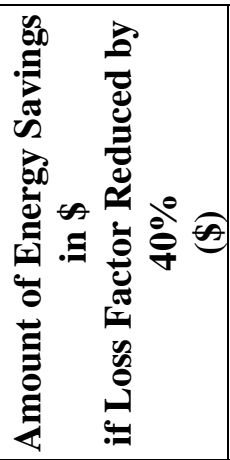 & 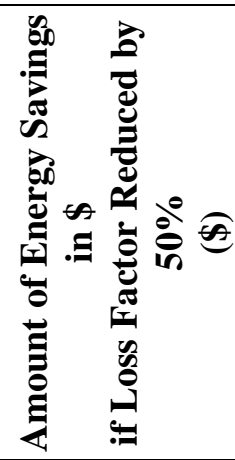 \\
\hline AAGF-B & 1,783 & 3,567 & 5,350 & 7,134 & 8,917 \\
\hline AASN-B & 2,047 & 4,095 & 6,142 & 8,190 & 10,237 \\
\hline AAAL-D & 563 & 1,125 & 1,688 & 2,250 & 2,813 \\
\hline AABN-D & 680 & 1,361 & 2,041 & 2,721 & 3,402 \\
\hline AACF-D & 556 & 1,113 & 1,669 & 2,226 & 2,782 \\
\hline AAMP-D & 781 & 1,561 & 2,342 & 3,123 & 3,904 \\
\hline AAACT-D & 511 & 1,022 & 1,534 & 2,045 & 2,556 \\
\hline AASPEC-D & 751 & 1,502 & 2,254 & 3,005 & 3,756 \\
\hline AAWIL-D & 656 & 1,311 & 1,967 & 2,623 & 3,279 \\
\hline D-78-D & 836 & 1,671 & 2,507 & 3,343 & 4,179 \\
\hline D-225-D & 183 & 367 & 550 & 734 & 917 \\
\hline AAAL-C & 262 & 524 & 786 & 1,048 & 1,310 \\
\hline AABN-C & 262 & 524 & 786 & 1,049 & 1,311 \\
\hline AACF-C & 229 & 457 & 686 & 915 & 1,143 \\
\hline AAMP-C & 326 & 651 & 977 & 1,303 & 1,628 \\
\hline AAACT-C & 503 & 1,005 & 1,508 & 2,011 & 2,514 \\
\hline AASPEC-C & 296 & 592 & 888 & 1,183 & 1,479 \\
\hline AAWIL-C & 415 & 829 & 1,244 & 1,659 & 2,073 \\
\hline D-78-C & 432 & 864 & 1,296 & 1,728 & 2,160 \\
\hline D-225-C & 617 & 1,234 & 1,851 & 2,469 & 3,086 \\
\hline
\end{tabular}


Table 4.21 presented return on investment by simple pay back calculation. Insulation cost per square footage was estimated through online available resources (Appendix F) and standard unionize license labour wages based in year 2015. In the Table 4.21 shows the payback period considering the savings calculation presented in the Table 4.20.

Table 4.21: Payback analysis based on different oven envelope loss factors

\begin{tabular}{|c|c|}
\hline $\begin{array}{c}\text { Loss Factor Increased } \\
\text { in Percent From Base Case }\end{array}$ & Payback \\
\hline (\%) & (year) \\
\hline $10 \%$ & 8.4 \\
\hline $20 \%$ & 4.2 \\
\hline $30 \%$ & 2.8 \\
\hline $40 \%$ & 2.1 \\
\hline $50 \%$ & 1.7 \\
\hline
\end{tabular}

A simple payback analysis performed to investigate the estimated return on investment. This analysis performed to check the feasibility of retrofit by adding more insulation on oven shell. It gives an estimated assumption of investment for energy savings measures. In the Figure 4.34 shows the payback period with investment on adding more insulation which in turn reduce loss factor on oven shell while the payback was presented in Table 4.20.

Figure 4.34.displays the payback period and insulation cost. Increased cost of insulation estimated at $20 \%$ increase in insulation value. Result shows that with the increase of insulation value, payback period decrease because of increasing savings. 


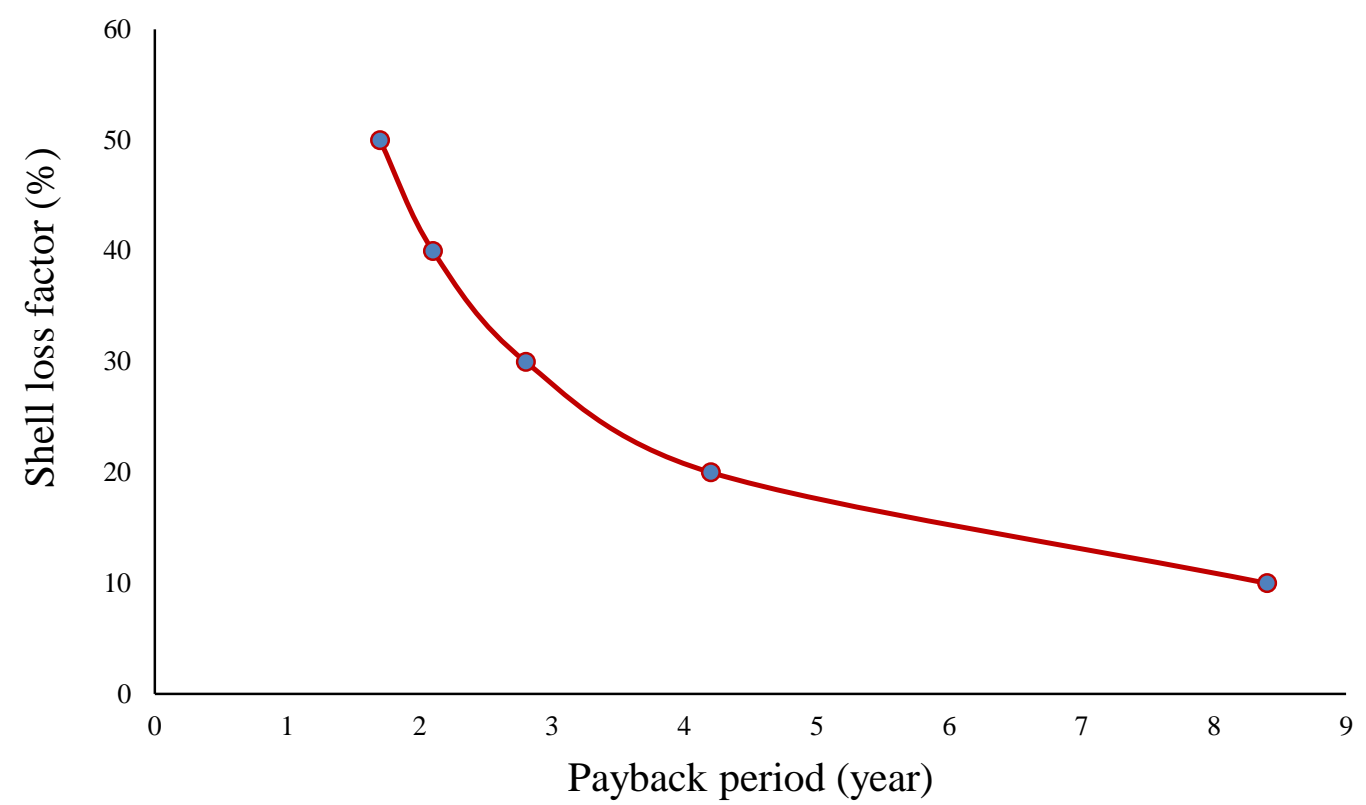

Figure 4.34: Payback period of investment savings based on different insulation loss factors (AASPEC)

\subsection{Maximum Potential Natural Gas Savings Analysis}

This research has quantified the maximum natural gas savings from oven consumption from $8 \%$ to $42 \%$ of total natural gas consumption in audited facilities. Columns 3 , 4, and 5 show the savings potential from exhaust, shell, and miscellaneous energy savings. As shown in the research of George Koch Sons, LLC, miscellaneous loss can be 1\% of the total consumption [55, 57], radiation loss included. The radiation loss has been calculated and presented in Table 4.22, Column 6. It was observed that the radiation loss of the audited facilities is from $2 \%$ to $4 \%$, which is higher than the research by George Koch Sons, LLC. Potential savings from miscellaneous loss have been calculated from existing loss by deducting the results of Column 6 of Table 4.5 from the radiation loss shown in the Table 4.22 of Column 6. Miscellaneous energy savings in Column 5, Table 4.22 are less than the radiation energy loss from ovens. Calculated maximum shell energy savings have been considered, as presented in Column 7 of Table 4.17. 
Table 4.22: Maximum potential savings of total natural gas consumption

\begin{tabular}{|c|c|c|c|c|c|c|}
\hline $\begin{array}{l}\text { Company } \\
\text { Name }\end{array}$ & $\begin{array}{c}\text { Total } \\
\text { Consumption }\end{array}$ & $\begin{array}{l}\text { Exhaust } \\
\text { Savings }\end{array}$ & $\begin{array}{l}\text { Shell } \\
\text { Savings }\end{array}$ & $\begin{array}{c}\text { Miscellaneous } \\
\text { savings }\end{array}$ & $\begin{array}{c}\text { Total } \\
\text { Savings }\end{array}$ & $\begin{array}{c}\text { Percentage } \\
\text { of Total } \\
\text { Savings }\end{array}$ \\
\hline & (m³ear) & (m³ear) & $\left(\mathrm{m}^{3} /\right.$ year $)$ & $\left(\mathrm{m}^{3} /\right.$ year $)$ & (m³ear) & $(\%)$ \\
\hline AAGF-B & $3,372,327$ & 172,966 & 35,668 & 0 & 834,536 & 25 \\
\hline AASN-B & 546,832 & 186,887 & 40,949 & 0 & 227,836 & 42 \\
\hline AAAL-D & \multirow{2}{*}{584,907} & 43,023 & 11,250 & 0 & \multirow[b]{2}{*}{151,308} & \multirow{2}{*}{26} \\
\hline AAAL-C & & 79,764 & 13,607 & 3,664 & & \\
\hline AABN-D & \multirow{2}{*}{363,976} & 29,696 & 11,130 & 0 & \multirow[b]{2}{*}{108,482} & \multirow{2}{*}{30} \\
\hline AABN-C & & 52,041 & 15,615 & 0 & & \\
\hline AACF-D & \multirow{2}{*}{437,383} & 30,956 & 10,224 & 0 & \multirow[b]{2}{*}{109,868} & \multirow{2}{*}{25} \\
\hline AACF-C & & 49,459 & 15,024 & 4,205 & & \\
\hline AAMP-D & \multirow{2}{*}{514,025} & 39,824 & 13,114 & 0 & \multirow[b]{2}{*}{117,191} & \multirow{2}{*}{23} \\
\hline AAMP-C & & 47,539 & 16,714 & 0 & & \\
\hline AAACT-D & \multirow{2}{*}{161,682} & 8,106 & 3,668 & 2,228 & \multirow[b]{2}{*}{34,296} & \multirow{2}{*}{21} \\
\hline AAMP-C & & 15,055 & 5,239 & 0 & & \\
\hline AASPEC-D & \multirow{2}{*}{369,364} & 12,493 & 5,243 & 0 & \multirow[b]{2}{*}{33,162} & \multirow{2}{*}{9} \\
\hline AASPEC-D & & 9,991 & 4,574 & 861 & & \\
\hline AAWIL-D & \multirow{2}{*}{298,809} & 19,004 & 6,513 & 13,003 & \multirow[b]{2}{*}{92,764} & \multirow{2}{*}{31} \\
\hline AAWIL-C & & 39,374 & 10,054 & 4,816 & & \\
\hline D-78-D & \multirow{2}{*}{951,907} & 19,608 & 5,917 & 154 & \multirow[b]{2}{*}{74,577} & \multirow{2}{*}{8} \\
\hline D-78-C & & 38,101 & 8,294 & 2,502 & & \\
\hline D-225-D & \multirow{2}{*}{$1,306,121$} & 32,493 & 8,640 & 29,295 & \multirow[b]{2}{*}{144,507} & \\
\hline D-225-C & & 61,736 & 12,343 & 0 & & \\
\hline
\end{tabular}

\subsection{Natural Gas Savings Analysis with Hours of Operations}

Based on analysis $15 \mathrm{~m}^{3} /$ hour to $139 \mathrm{~m}^{3} /$ hour of natural gas input can be saved through proper addressing the exhaust loss, shell loss, and radiation loss. The natural gas saving are presented in Table 4.23. 
Table 4.23: Natural gas savings per hour of operation

\begin{tabular}{|c|c|c|c|}
\hline $\begin{array}{c}\text { Company } \\
\text { Name }\end{array}$ & $\begin{array}{c}\text { Hour of } \\
\text { Operation }\end{array}$ & $\begin{array}{c}\text { Estimated } \\
\text { Total Natural } \\
\text { Gas Savings }\end{array}$ & $\begin{array}{c}\text { Natural gas } \\
\text { Savings Per } \\
\text { Hour of } \\
\text { Operation }\end{array}$ \\
\hline AAGF & 6000 & 834,536 & 139 \\
\hline AASN & 7488 & 227,836 & 30 \\
\hline AAAL & 2500 & 151,308 & 61 \\
\hline AABN & 4080 & 108,482 & 27 \\
\hline AACF & 5125 & 109,868 & 21 \\
\hline AAMP & 6000 & 117,191 & 20 \\
\hline AAACT & 2250 & 34,296 & 15 \\
\hline AASPEC & 2000 & 33,162 & 17 \\
\hline AAWIL & 2000 & 92,764 & 46 \\
\hline D-78 & 2000 & 74,577 & 37 \\
\hline D-225 & 2000 & 144,507 & 72 \\
\hline
\end{tabular}

Figure 4.35 displays natural gas savings per hour of operation of the audited companies. Analysis shows AAGF have the highest opportunity for hourly saving, while AAACT have the lowest. It can be seen that savings opportunity increases with the increase of hour of operation.

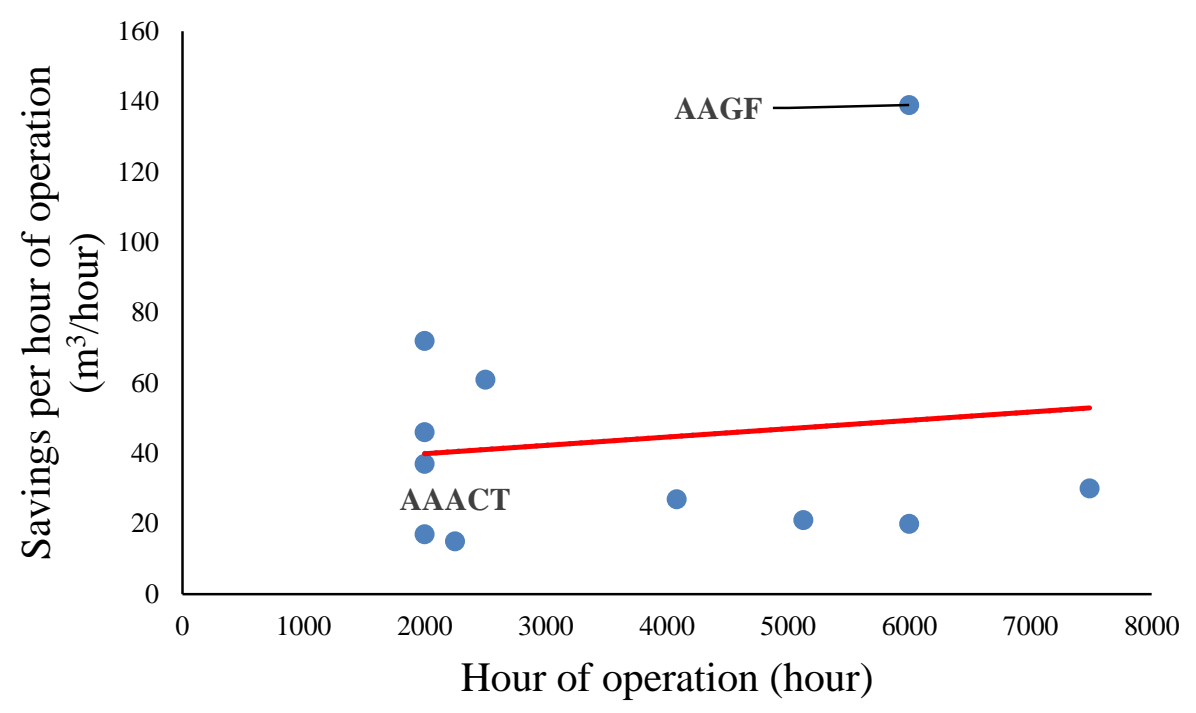

Figure 4.35: Natural gas savings per hour of operation 


\section{Chapter 5: Result and Discussion of SMEs' Energy Consumption}

This study has several findings regarding energy savings. First, this study estimates that by using the ventilation requirement methodology by Enbridge Gas Distribution Inc. $[53,55,56,57]$ that prevents exhaust energy loss, ovens can consume between $19 \%$ and $53 \%$ less energy. These estimates are presented in Table 4.15.

Second, around $14 \%$ to $27 \%$ energy savings can be realized from oven consumption by limiting oven shell loss. These estimates were presented in Figure 4.14 and 4.18.

This study observed that for two bakeries, $82 \%$ and $88 \%$ of the energy is consumed for processing their products. The data are and presented in Table 4.1. Plant AASPEC and D-78 usages less natural gas energy in process oven because the process equipment runs on electricity and the plant has a large area. Of the process energy consumption, $26 \%$ to $73 \%$ was used for direct-fired ovens, which was shown in Table 4.1.

The eleven companies audited for this study all use ovens. Two use bake ovens, while the rest use dry-off and cure ovens. It was estimated that bake ovens use $47 \%$ to $73 \%$ of process energy, while ovens in the finishing companies use $26 \%$ to $68 \%$. These were presented in Table 4.1 .

Natural gas was the main source for maintaining indoor air quality for most of the large facilities. Research found that the energy intensity by area in bake ovens is around $24 \mathrm{~m}^{3} / \mathrm{ft}^{2}$ to $30 \mathrm{~m}^{3} / \mathrm{ft}^{2}$ (Table 4.2), whereas for dry-off and cure ovens it is $7 \mathrm{~m}^{3} / \mathrm{ft}^{2}$ to $36 \mathrm{~m}^{3} / \mathrm{ft}^{2}$ (Table 4.2). This same study found that energy intensity by volume in bake ovens is around $64 \mathrm{~m}^{3} / \mathrm{ft}^{3}$ to $77 \mathrm{~m}^{3} / \mathrm{ft}^{3}$, whereas for dry-off and cure ovens it is $16 \mathrm{~m}^{3} / \mathrm{ft}^{3}$ to $65 \mathrm{~m}^{3} / \mathrm{ft}^{3}$. The same oven does not always exhibit have the same energy intensity by volume and energy intensity by area (e.g., AASPECD).

This study also observed that the suitable methodologies for benchmarking are: (a) energy 
intensity index which estimates energy consumption per square footage $\left(\mathrm{m}^{3} / \mathrm{ft}^{2}\right)$; (b) energy consumption per unit volume $\left.\left(\mathrm{m}^{3} / \mathrm{ft}^{2}\right)\right)$ (Table 4.2 and Table 4.3); and (c) production hours index (Table 4.11, column 8 and Figure 4.28)

The research observed that potentially around $8 \%$ to $83 \%$ of energy loss during non-productive hours could be saved and thus help lower production costs (Table 4.13). This is conclusion was reached because there were more non-productive hours. There were less non-productive hours during summer, and energy consumption during non-productive hours decreased (Table 4.13, Table 4.14 and Figure 4.31)

Potential savings can be realized from many retrofits such as the addition of a VFD controller, insulation (Table 4.15, Table 4.16, and Table 4.17). Depending on the investment and the type of estimated retrofits, return on investment can be realized in less than a year or in ten years (Table 4.18, Table 4.19, Table 4.20, and Table 4.21).

The research observed that potentially around $8 \%$ to $42 \%$ of total natural gas loss can be saved through different retrofits thus help to lower the production cost (Table 4.22). Natural gas savings per hour of operation observed from $15 \mathrm{~m}^{3} /$ hour of $139 \mathrm{~m}^{3} /$ hour.

\subsection{Savings from installing Variable Frequency Drive (VFD)}

Variable frequency drive (VFD) is an electro-mechanical device that controls the speed of AC motors and the torque by varying the motor input frequency and voltage. Variable Frequency Drive (VFD) plays an important role in energy management with regards to technology. It was observed that major energy savings form Eddy-current and hysteresis loss accounted for 15-25\% of the overall losses. It was also observed that the starting current of a motor was too high, usually between 3 to 8 times the full-load current. As a result, the voltage surges in the power 
system. On the other hand, if full torque is applied instantly at the start of the process, the mechanical shock can eventually damage the drive system, including the motor or fan mount shaft. Therefore, VFD is suitable where mechanical considerations like variable torque, constant torque, and constant horsepower are involved. It was proven that VFD can help realize direct savings in electrical energy consumption and indirect savings from exhaust losses. Electrical energy is saved by varying the motor speed and torque, while exhaust energy can be saved through the proper mixing of natural gas and oxygen ratio. At the exhaust duct, companies can install an oxygen sensor which would measure the percentage of oxygen gas in the exhaust flue gas. The percentage of oxygen gas in the exhaust flue can control the motor speed at the inlet

duct of the oven. A potential savings can be achieved from $19 \%$ to $61 \%$ of oven energy consumption after installing VFD with controller.

\subsection{Savings from Insulation Correction}

Insulation reduces the exchange of heat through a surface; that is, an insulated surface lessens the amount of warm air escaping through the surface. It acts as a barrier for heat loss and gain. Therefore, the amount of energy needed for this purpose could be reduced. Insulation is the most practical and cost-effective way to make an oven more energy-efficient $[111,112,113]$. Insulation can be selected based on R-value and cost analysis. In this study, it was observed that shell loss calculated from $18 \%$ to $31 \%$ can be reduced based on insulation properties having an loss factor reduced from $10 \%$ to $50 \%$ and simulated energy savings potential is addressed in Table 4.18 . 


\section{Chapter 6: Conclusion and Recommendations}

Burners are devices which mix molecules of fuel with molecules of air. An efficient oven depends on burner performance. A poorly designed oven with an efficient burner may perform better than a well-designed oven with a poor burner. Burners are designed to maximize combustion efficiency while minimizing the release of emissions.

An efficient natural gas burner requires only $2 \%$ to $3 \%$ excess oxygen or $10 \%$ to $15 \%$ excess air in the gas, to burn fuel without forming excess carbon monoxide.

A natural gas burner can be more efficient if it is provided with $2 \%$ to $3 \%$ excess oxygen or $10 \%$ to $15 \%$ excess air in the flue gas, to burn fuel without forming carbon monoxide. Therefore, a proper air-to-fuel mixture is important for burner efficiency without constant adjustment. Usually burners with complex linkage designs can't maintain air-to-fuel setting over time. This is a cause of inefficiency. So a burner using servomotors with parallel positioning which independently control the quantities of fuel and air delivered to the burner head can improve efficiency more than complex linkage designed burners. An advantage of servomotors with parallel positioning burners is that they don't have complex linkages, which allows for easy tune-ups and minor adjustments, while eliminating hysteresis, or lack of retrace ability, and provide accurate pointto-point control. These are the reasons for consistent performance and repeatability, adjusting burners for different firing rates. Other alternatives are burners with a single drive or jackshaft.

In assessing overall efficiency and potential for oven energy savings, the parameters of significant importance are temperature, flow rate of inlet air and dry flue gas, processing material flow rate, and insulation of shell, etc. The temperature can be measured by a laser temperature gun, or thermocouple probe. The installation of economizer or flue-gas air pre-heaters are 
practical ways of reducing stack temperature while reusing oven inlet air. Studied companies observed exhaust gas temperatures of $350^{\circ} \mathrm{F}$ to $450^{\circ} \mathrm{F}\left(177^{\circ} \mathrm{C}\right.$ to $\left.232^{\circ} \mathrm{C}\right)$.

\subsection{New findings in this research}

Research work was accomplished with the contribution of Enbridge's University Partnership Program (UPP) to identify natural gas savings in small and medium-sized industries. In this respect, the author has accomplished the following tasks and achieved the following goals:

- Development of Excel based calculating tool by which oven energy balance can be calculated through required data sets without on-site energy audit

- Development of code in Visual basic to create a portable version of calculating tools

- Consolidation of energy data (natural gas) from 11 small and medium-sized industries within the GTA

- Energy consumption analysis of ovens of small and medium-sized industries within the GTA and identifying major losses and potential savings (such as exhaust loss, shell loss, miscellaneous loss, etc.)

- Development of a few indices by which industries that have ovens can be classified based on their efficient use of natural gas

- Assessment of financial and environmental benefits in terms of natural gas savings and greenhouse gas emissions

\subsection{Limitations of this study}

At the beginning of this project, the goal was to aim for a minimum of 50 companies whose audited energy data could be obtained from SMEs through Enbridge Gas Distribution Inc. to 
draw a statistical analysis. However, based on available data, this project study analyzed data from 11 SME companies. Among them two are bakeries, and the remaining 9 are finishing companies. These results are a sample analysis, but could not be tested for robustness due to data limitation. These results would have been highly accepted if they had been obtained from the minimum required companies (at least 50 companies' data). Therefore, a research opportunity is there to test this methodology.

Energy audits largely rely on accurate information from facilities. These are: temperature readings from different energy served systems, air-flow rates of HVAC system and ovens, energy data from sub-metering and major equipment, and more. This study relies on very limited data. These are: utility bills, schedules, some of the data from ovens, and some data collected from internet searches. Due to limited resources of measuring equipment and tools, that accurate information could not be retrieved. Many of the results are based on estimation and discussion with experts. The same results were obtained for savings calculations. The prices were taken from the internet and were included in payback calculations.

\subsection{Possible Future Work}

Plenty of potential for future research work was identified during this research, which is energy savings potential based on design parameters of ovens and retrofits. Another opportunity was observed to analyze oven burners with optimized thermal capacity design. 


\section{Appendix A}

\section{Sample calculations:}

1. Production throughput (AAAL)

$\mathrm{m}_{\mathrm{p}}=$ Product mass $=15[\mathrm{lb}]$

$\mathrm{V}_{\text {line }}=$ Conveyor speed $=15[\mathrm{ft} / \mathrm{min}]$

Loading per hook spece $=$ Loading $/ \mathrm{h}_{\mathrm{s}}=2$

Production throughput $=\mathrm{m}_{\mathrm{p}} \times \mathrm{V}_{\text {line }} \times 60[\mathrm{hr} / \mathrm{min}] \times$ Loading $/ \mathrm{h}_{\mathrm{s}}$

$$
=15[\mathrm{lb}] \times 8[\mathrm{ft} / \mathrm{min}] \times 60[\mathrm{hr} / \mathrm{min}] \times 2=13500[\mathrm{lb} / \mathrm{min}]
$$

2. Energy required per hour (AAAL)

$=\mathrm{m}_{\mathrm{p}}[\mathrm{lb}] \times \mathrm{C}_{\mathrm{p}}\left[\mathrm{Btu} / \mathrm{lb}^{\mathrm{o}} \mathrm{F}\right] \mathrm{x} \Delta \mathrm{T}\left[{ }^{\mathrm{o}} \mathrm{F}\right]$

$=12[\mathrm{lb}] \times 0.12\left[\mathrm{Btu} / \mathrm{lb}^{\circ} \mathrm{F}\right] \times 330\left[{ }^{\circ} \mathrm{F}\right]$

$=540[\mathrm{Btu} / \mathrm{pcs}]$

3. Exhaust requirement (AAAL)

Burner capacity $=3.5$ inch

$$
=3.5 \times 183=640.5=651 \text { MMBtu }[\text { SCFM }]
$$

$=12[\mathrm{lb}] \times 0.12\left[\mathrm{Btu} / 1 \mathrm{~b}^{\circ} \mathrm{F}\right] \times 330\left[{ }^{\circ} \mathrm{F}\right]$

$=540[\mathrm{Btu} / \mathrm{pcs}]$

4. Correction factor $(\mathrm{CF})=\frac{\text { Exhaust temperature }+460}{\text { Inlet temperature }+460}=\frac{370+460}{70+460}=1.57$

5. $\mathrm{ACFM}$ required $=641[\mathrm{SCFM}] \times 1.57[\mathrm{CF}]=1,006 \mathrm{ACFM}$

6. Exhaust at constant volume $=\frac{\text { Oven volume }\left[\mathrm{ft}^{2}\right] \mathrm{x} 4}{\text { purge time }}=\frac{10,000 \times 4}{16}=2,500[\mathrm{SCFM}]$

7. Exhaust energy loss $=[\mathrm{SCFM}] \times 1.08\left[\mathrm{Btu} / \mathrm{lb}{ }^{\circ} \mathrm{F}\right] \mathrm{x} 300\left[{ }^{\circ} \mathrm{F}\right] \mathrm{x} 2500[\mathrm{Year} / \mathrm{hr}] / 35000$

$$
=2500 \times 1.08 \times 300 \times 2500 / 35000
$$




$$
=57857 \mathrm{~m}^{3} / \text { year }
$$

8. Exhaust savinngs $=$ Conatant volume exhaust - require exhaust

$$
\begin{aligned}
& =2,500[\mathrm{SCFM}]-651[\mathrm{SCFM}] \\
& =1849[\mathrm{SCFM}]
\end{aligned}
$$

9. Product energy consumption (AAAL)

Actual product in a year $=1,500,000 \mathrm{pcs}$

Energy required per product $=540 \mathrm{Btu} / \mathrm{pcs}$

Product energy required $=$ Energy required per product $\mathrm{x}$ No of product in a year

$$
\begin{aligned}
& =540[\mathrm{Btu} / \mathrm{pcs}] \times 1,500,000[\mathrm{pcs}] / 35000 \\
& =23,143 \mathrm{~m}^{3} / \text { year }
\end{aligned}
$$

10. Materail handling loss $(\mathrm{AAAL})=3 \%$ of the total oven consumption

$$
\begin{aligned}
& =0.03 \times 120184\left[\mathrm{~m}^{3} / \text { year }\right] \\
& =3606\left[\mathrm{~m}^{3} / \text { year }\right]
\end{aligned}
$$

11. Shell loss (AAAL)

$=$ Shell area $\left[\mathrm{ft}^{2}\right] \mathrm{x}$ loss factor $\mathrm{x} \Delta \mathrm{T}\left[{ }^{\circ} \mathrm{F}\right] \mathrm{x}$ operating hour $[\mathrm{year} / \mathrm{hr}]$ 135000

$=4200\left[\mathrm{ft}^{2}\right] \times 0.25 \times 300\left[{ }^{\circ} \mathrm{F}\right] \times 2500[$ year $/ \mathrm{hr}] / 35000$

$=22,500 \mathrm{~m}^{3} /$ year

11. Oven energy intensity in terms of area

Oven area $=4,200\left[\mathrm{ft}^{2}\right]$

Oven consumption $=120,184\left[\mathrm{~m}^{3} /\right.$ year $]$

Energy intensity in terms of area $=$ oven consumption $\left[\mathrm{m}^{3} /\right.$ year $] /$ oven area $\left[\mathrm{ft}^{2}\right]$

$$
=120,184\left[\mathrm{~m}^{3} / \text { year }\right] / 4,200\left[\mathrm{ft}^{2}\right]=29\left[\mathrm{~m}^{3} / \mathrm{ft}^{2}\right]
$$


12. Oven energy intensity in terms of volune

Oven volume $=10,000\left[\mathrm{ft}^{3}\right]$

Oven consumption $=120,184\left[\mathrm{~m}^{3} /\right.$ year $]$

Energy intensity in terms of area $=$ oven consumption $\left[\mathrm{m}^{3} / \mathrm{year}\right] /$ oven volume $\left[\mathrm{ft}^{3}\right]$

$$
=120,184\left[\mathrm{~m}^{3} / \text { year }\right] / 10,000\left[\mathrm{ft}^{3}\right]=12\left[\mathrm{~m}^{3} / \mathrm{ft}^{3}\right]
$$

13. Payback calculation after improving loss factor

Oven area $=5044\left[\mathrm{ft}^{2}\right]$

Insulation cost $=\$ 15,435$ (@3.06 per square footage $)$

Doller savings after improving of insulation value of $10 \%$ than base case

Savings $=7,350 \times 0.25=\$ 1,838$

Payback period $=15,438 / 1,838=8.4$ 


\section{Appendix B}

\section{Collected data for ovens from energy audit}

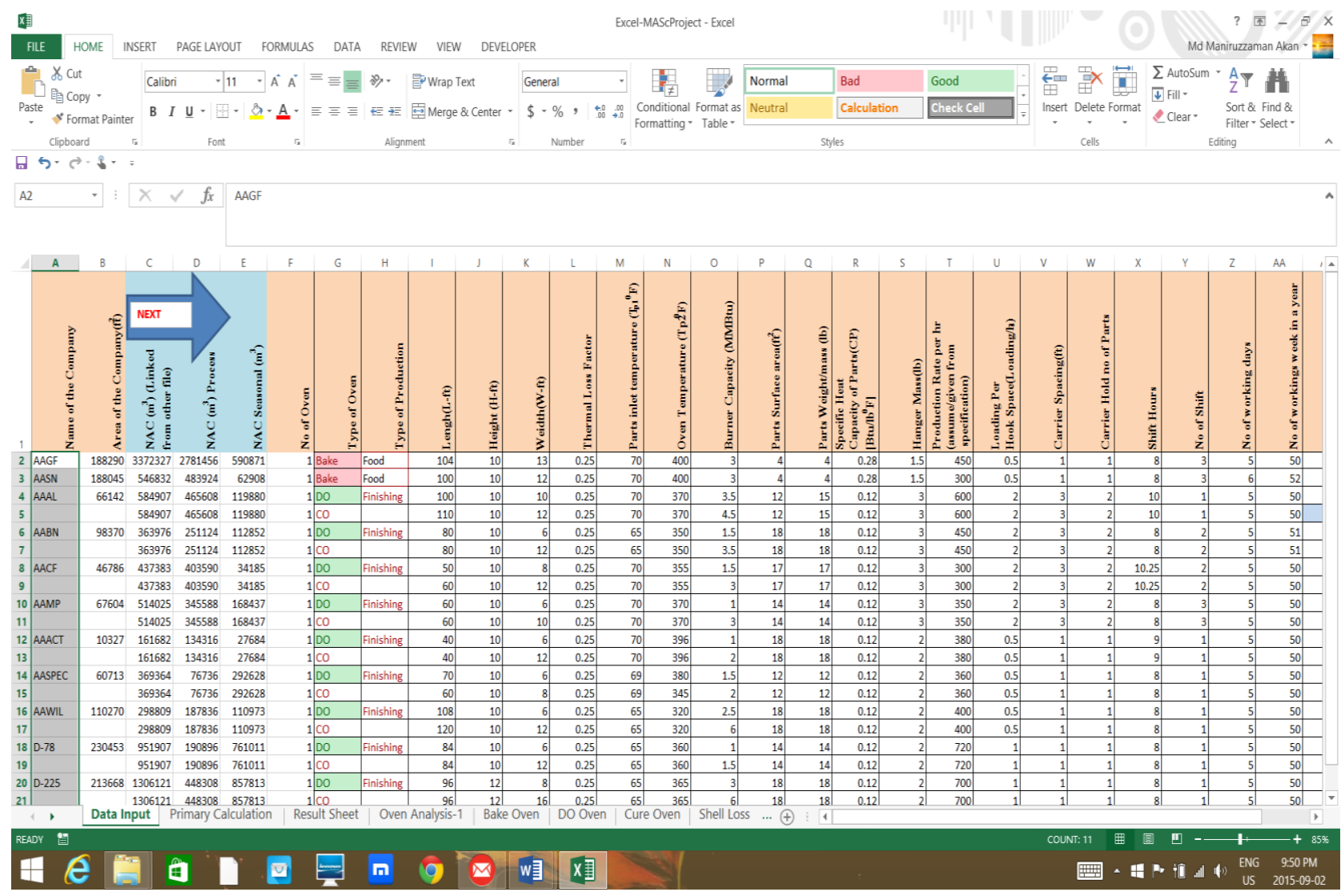




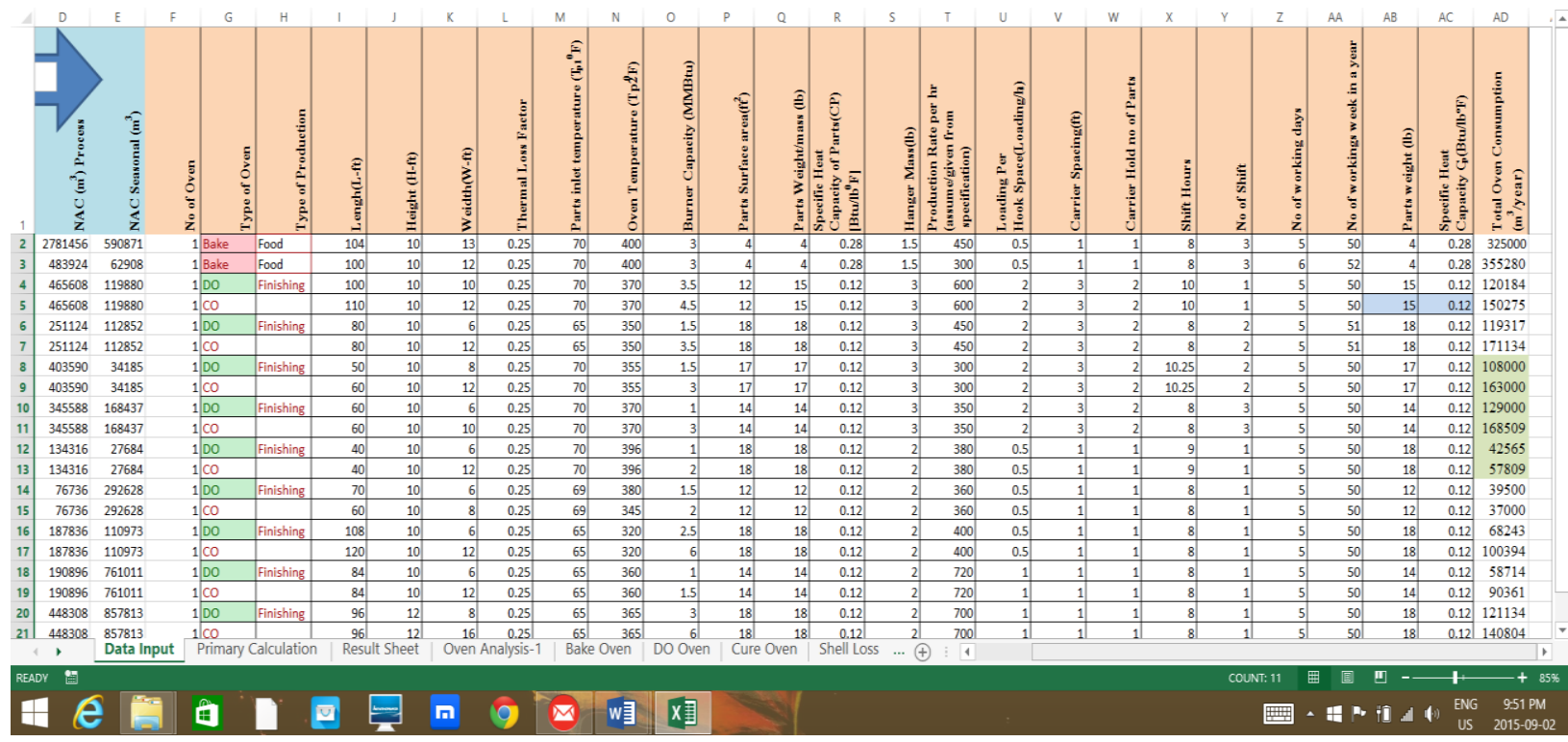
$\begin{array}{llllll}\text { FIIE } & \text { HOME INSERT PAGELAYOUT FORMULAS DATA REVEW VIEW DEVELOPER }\end{array}$ Excel-MAScProject - Excel

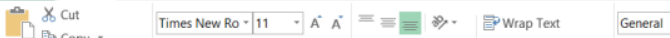

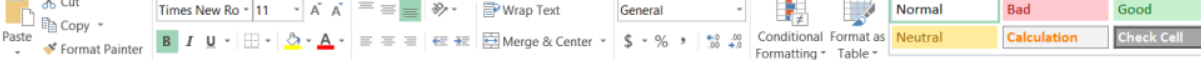
Ch. $\rightarrow \cdot$ :

\begin{tabular}{lll|l}
$\mathrm{k} 3$ & $x \vee f_{x}$ & No of workings hours in a year
\end{tabular}

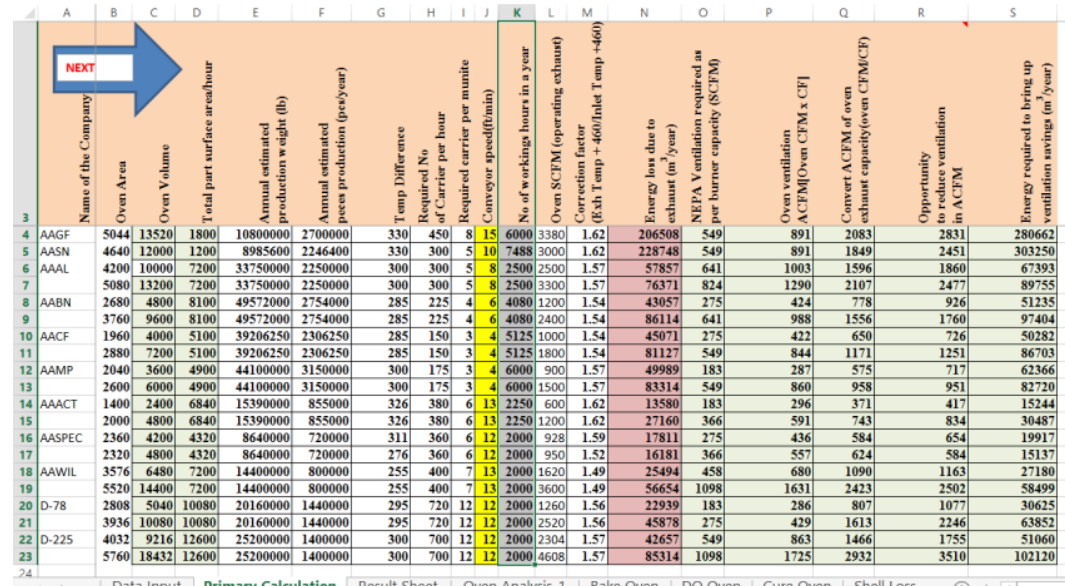

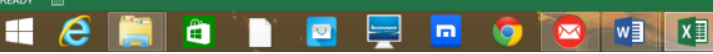




\section{Appendix C}

\section{Calculated data for ovens}

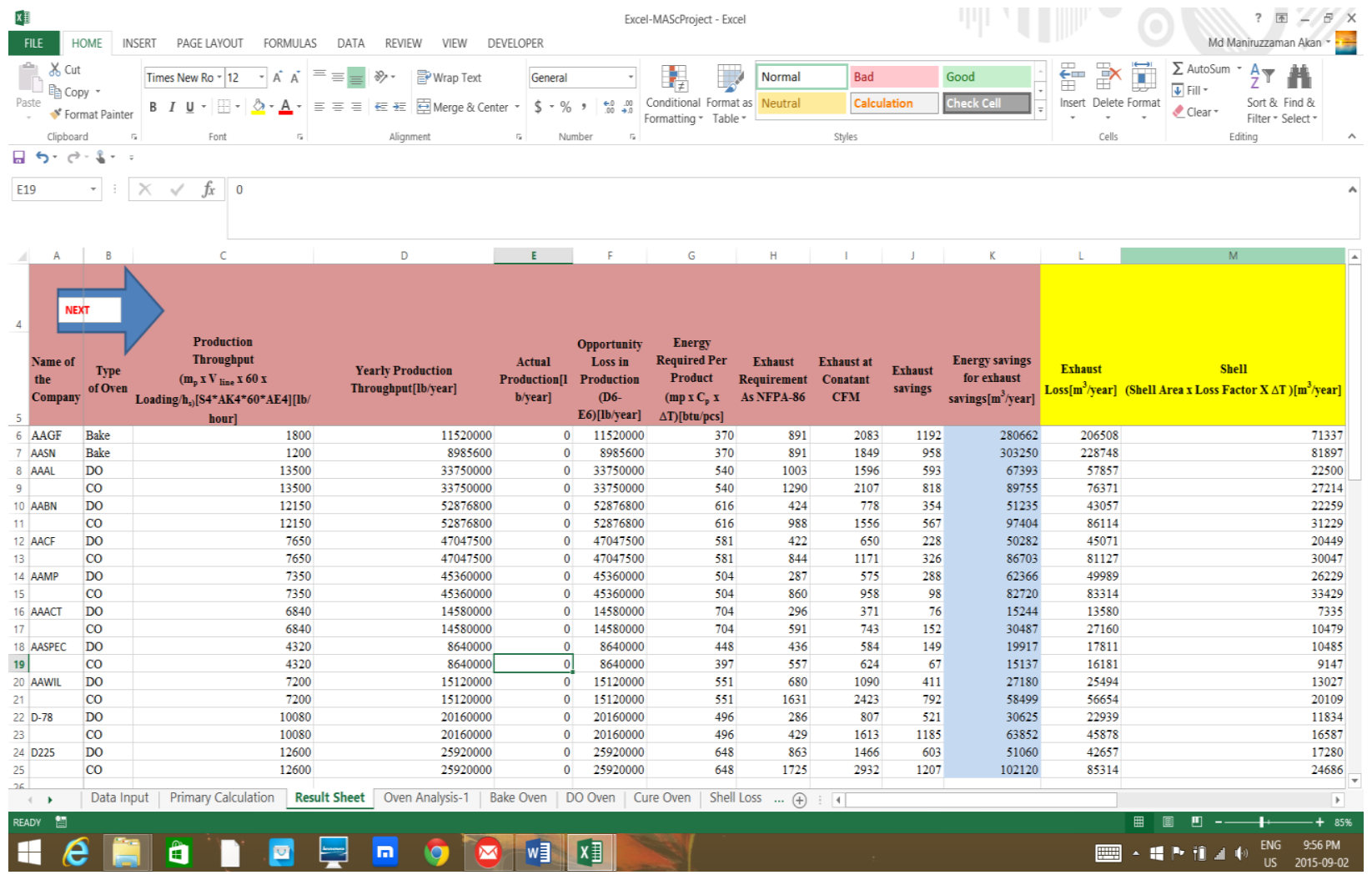




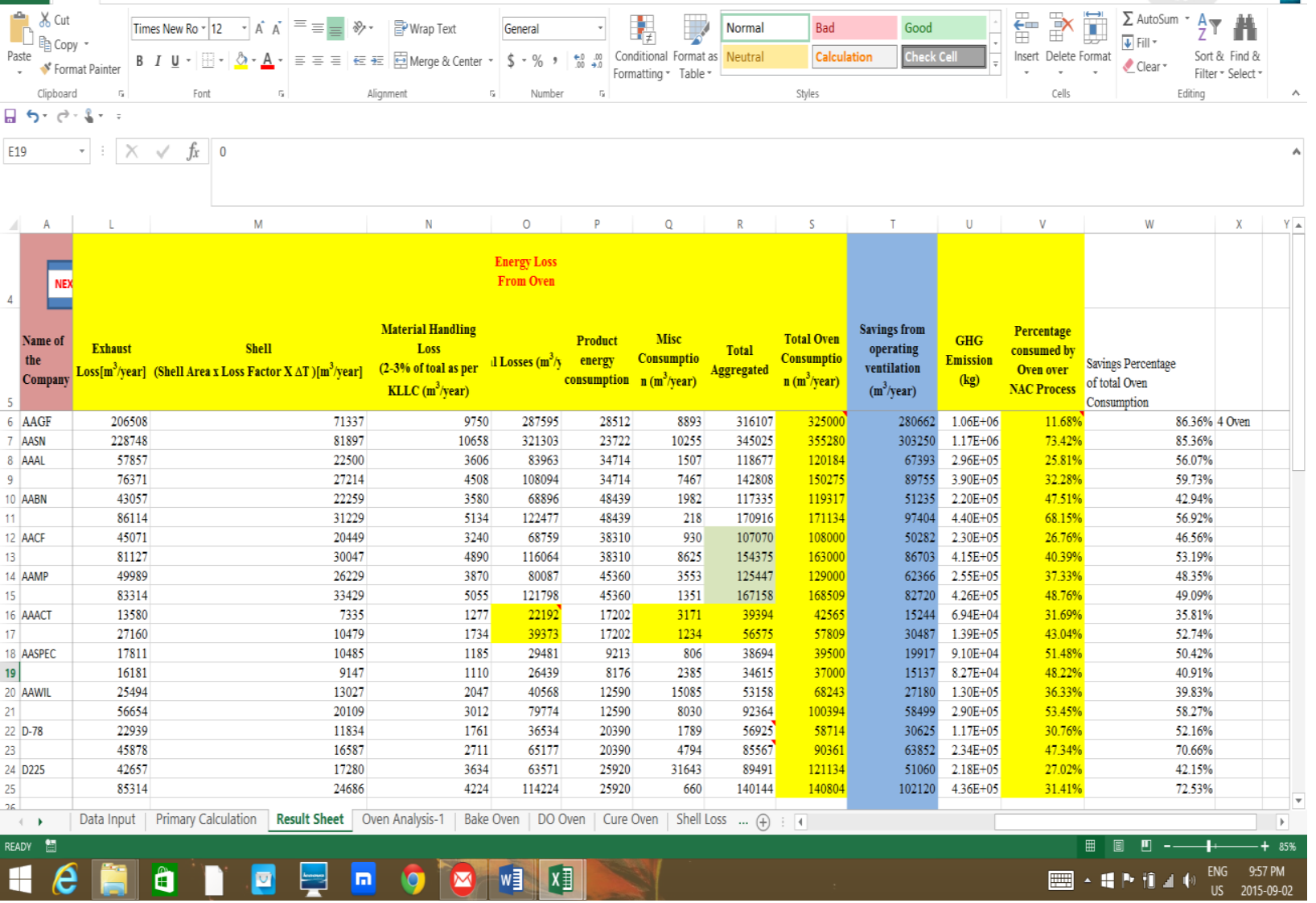




\section{Appendix D}

\section{Summary result of dry-off ovens}

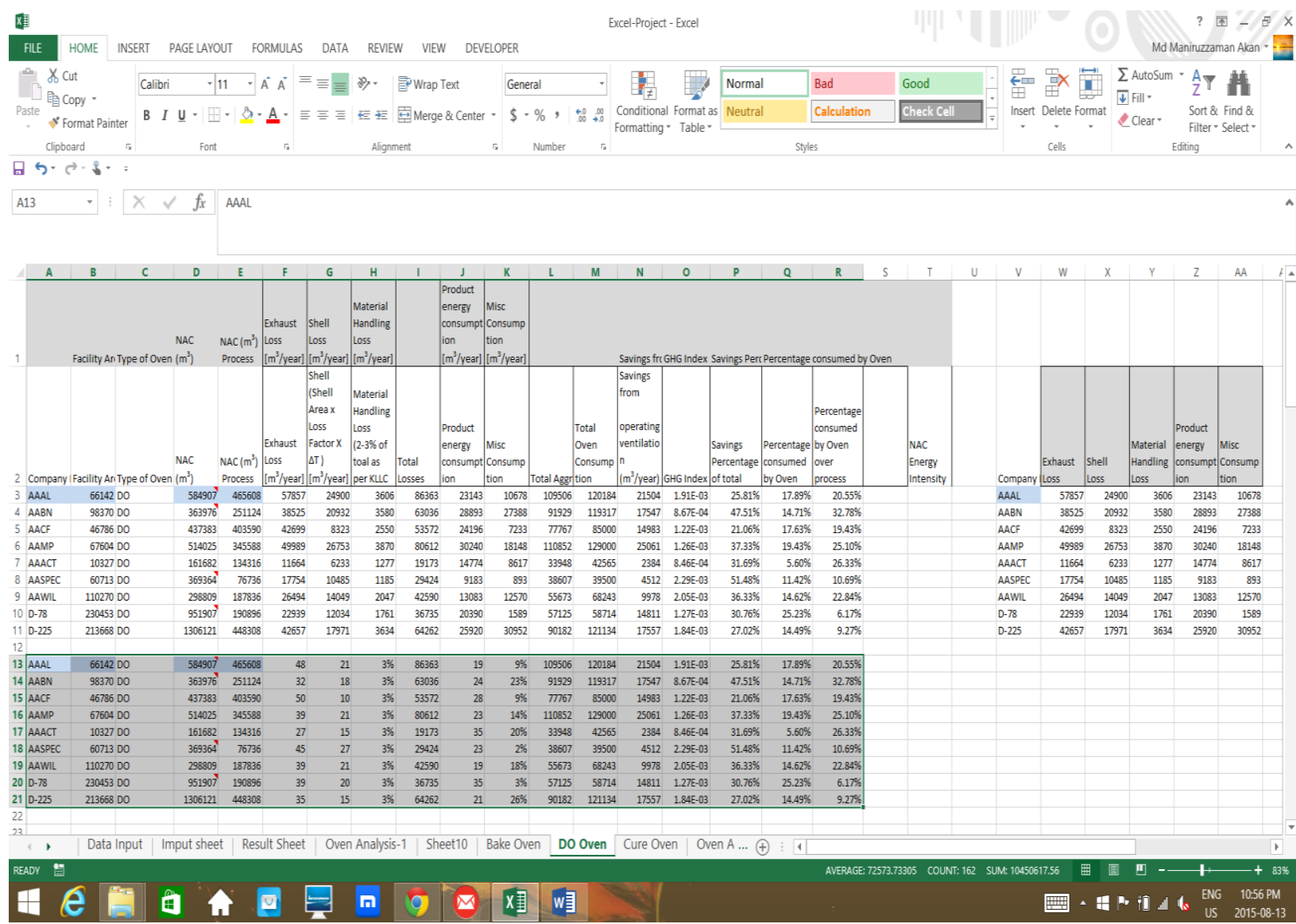




\section{Appendix E}

\section{Summary result of cure ovens}

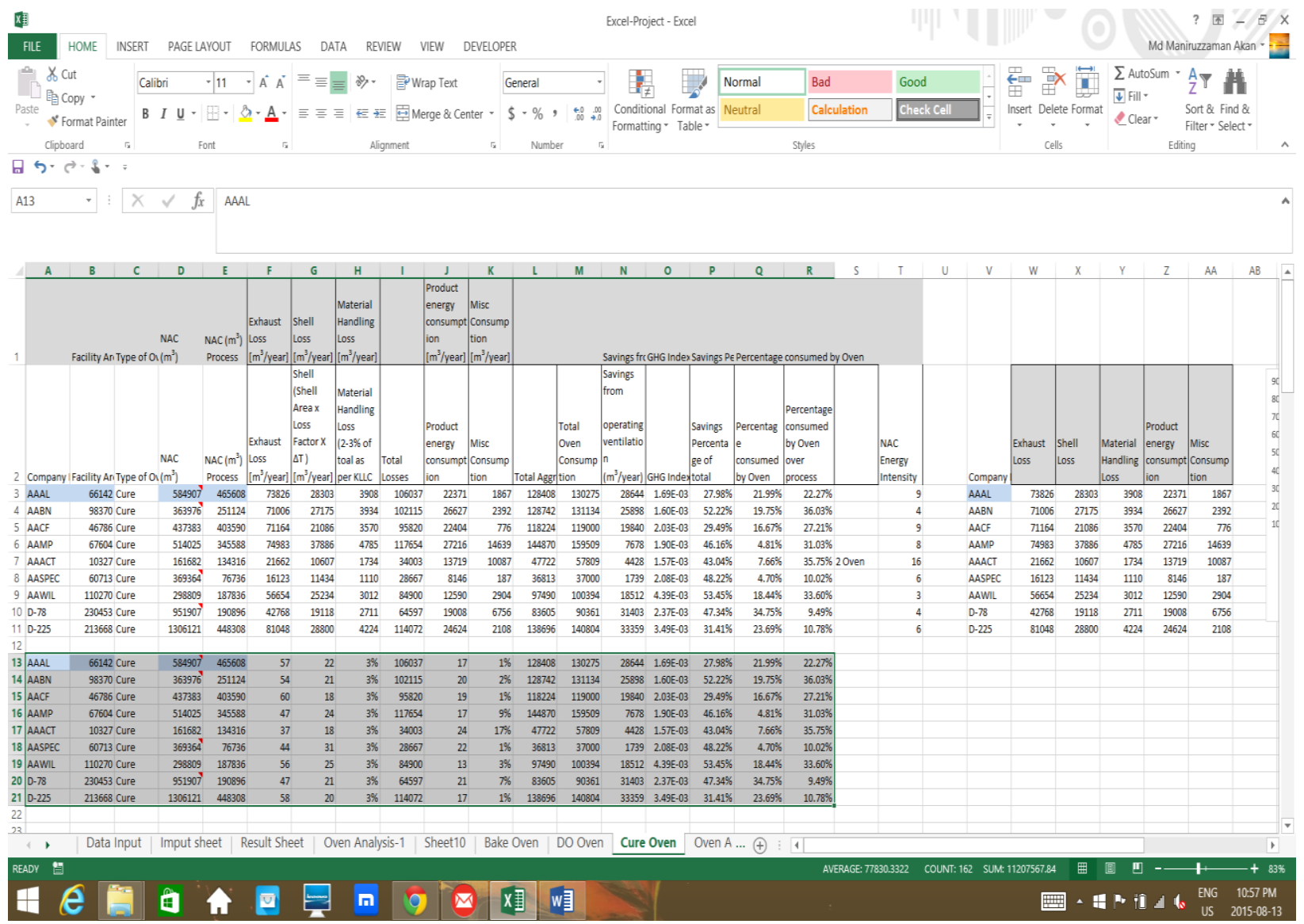




\section{Appendix F}

Utility bill collected during energy audit

1. AAAL

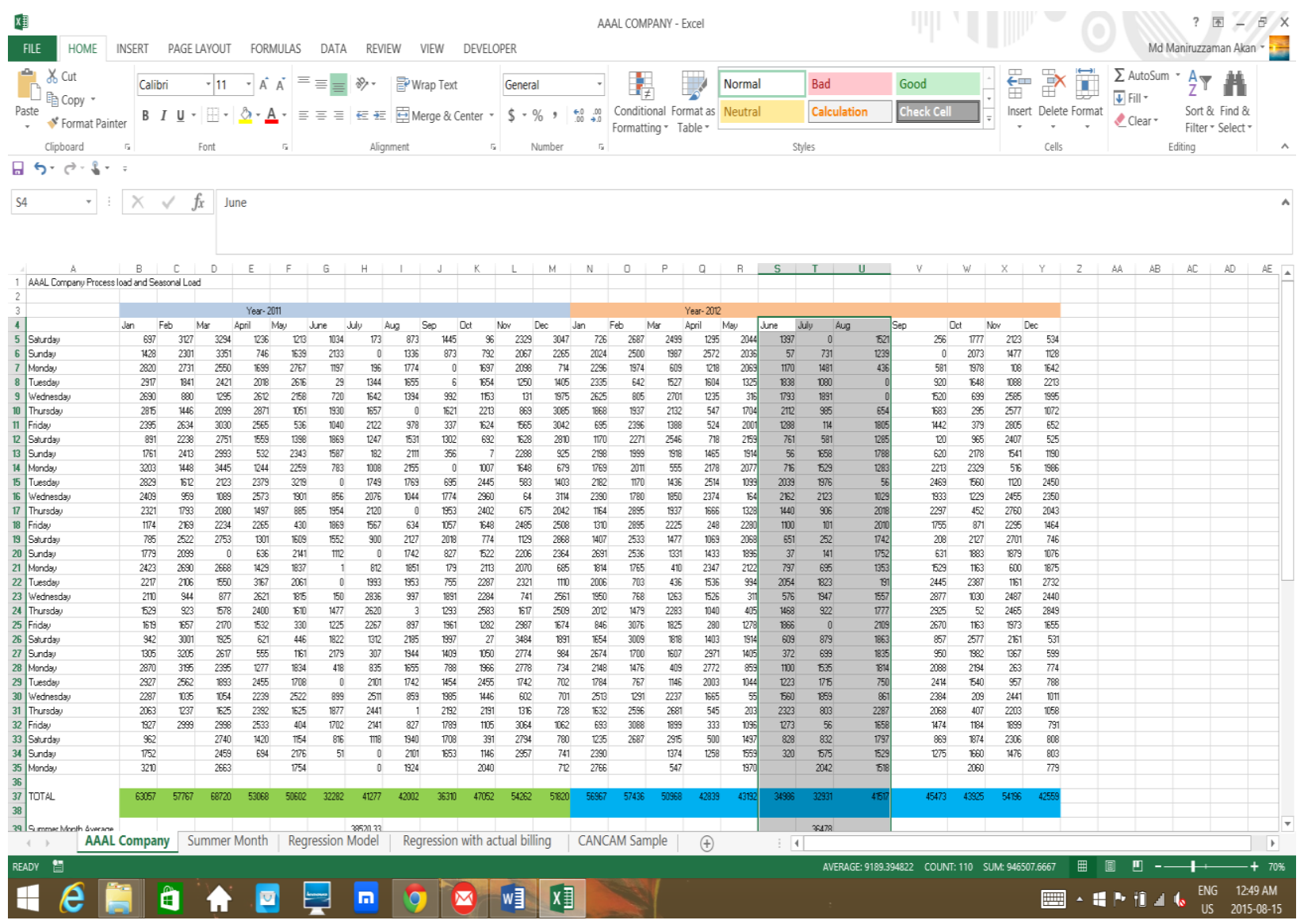




\section{AAGF}

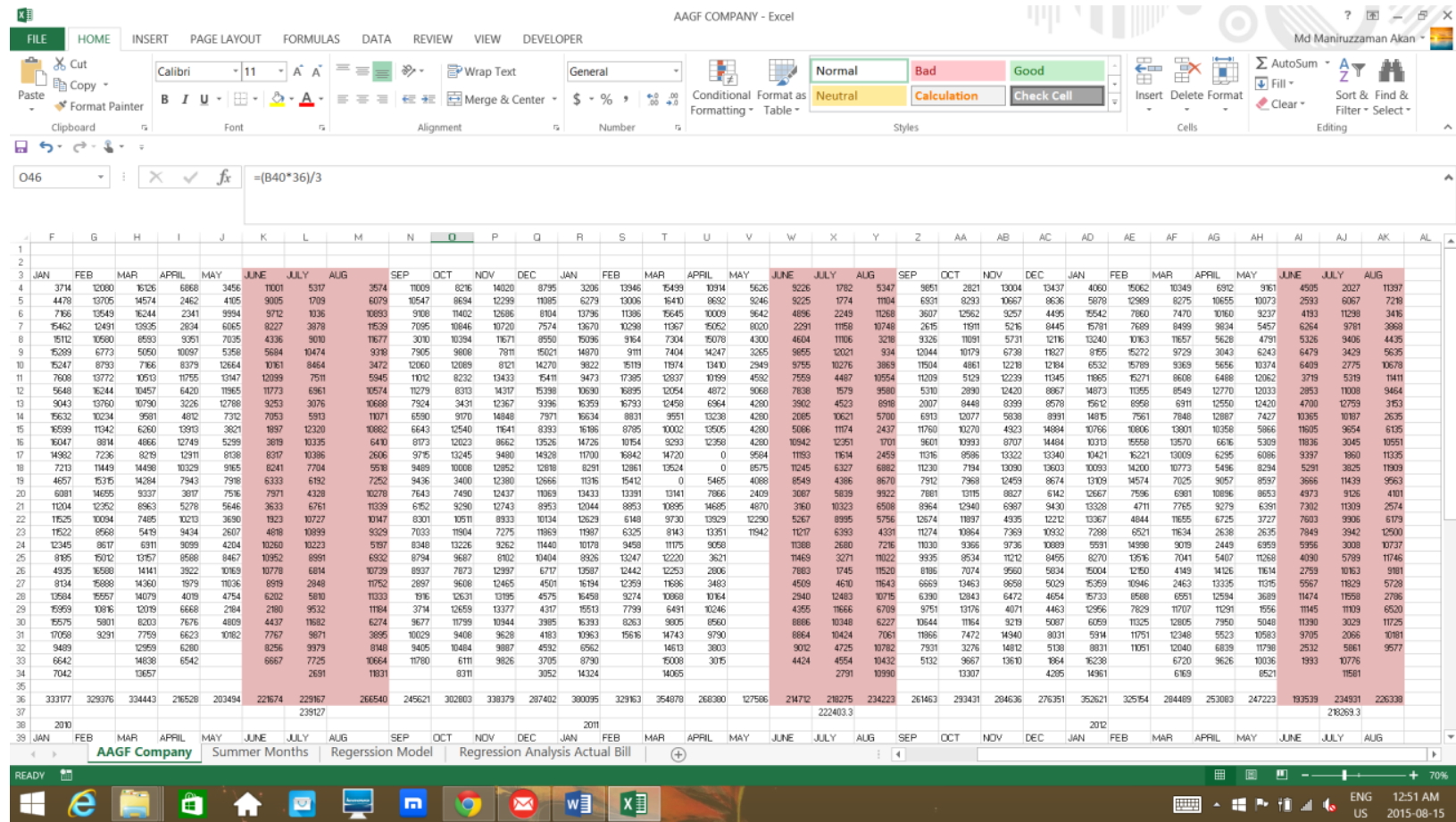

\section{AASN}

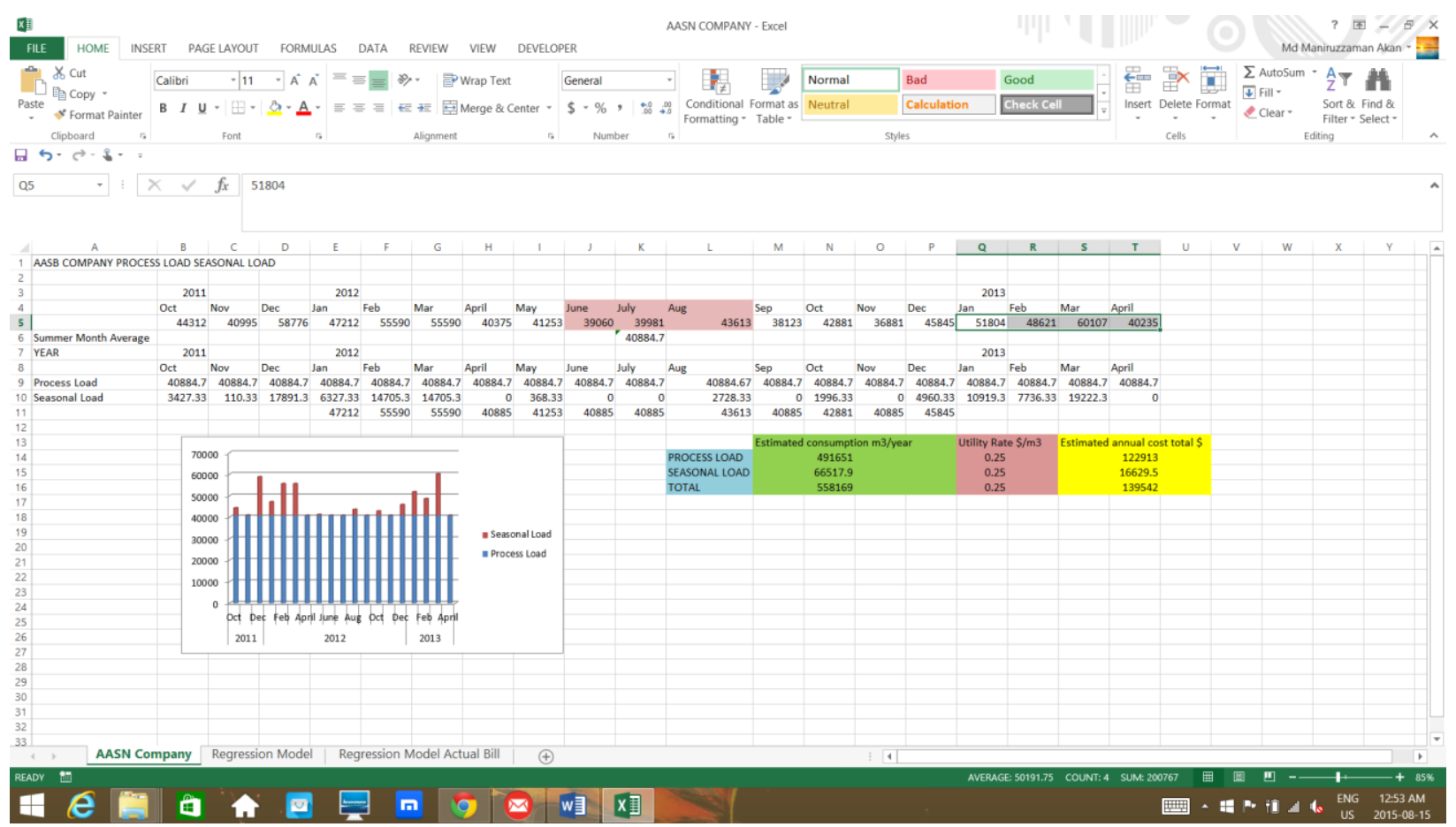




\section{4. $\mathrm{AACF}$}

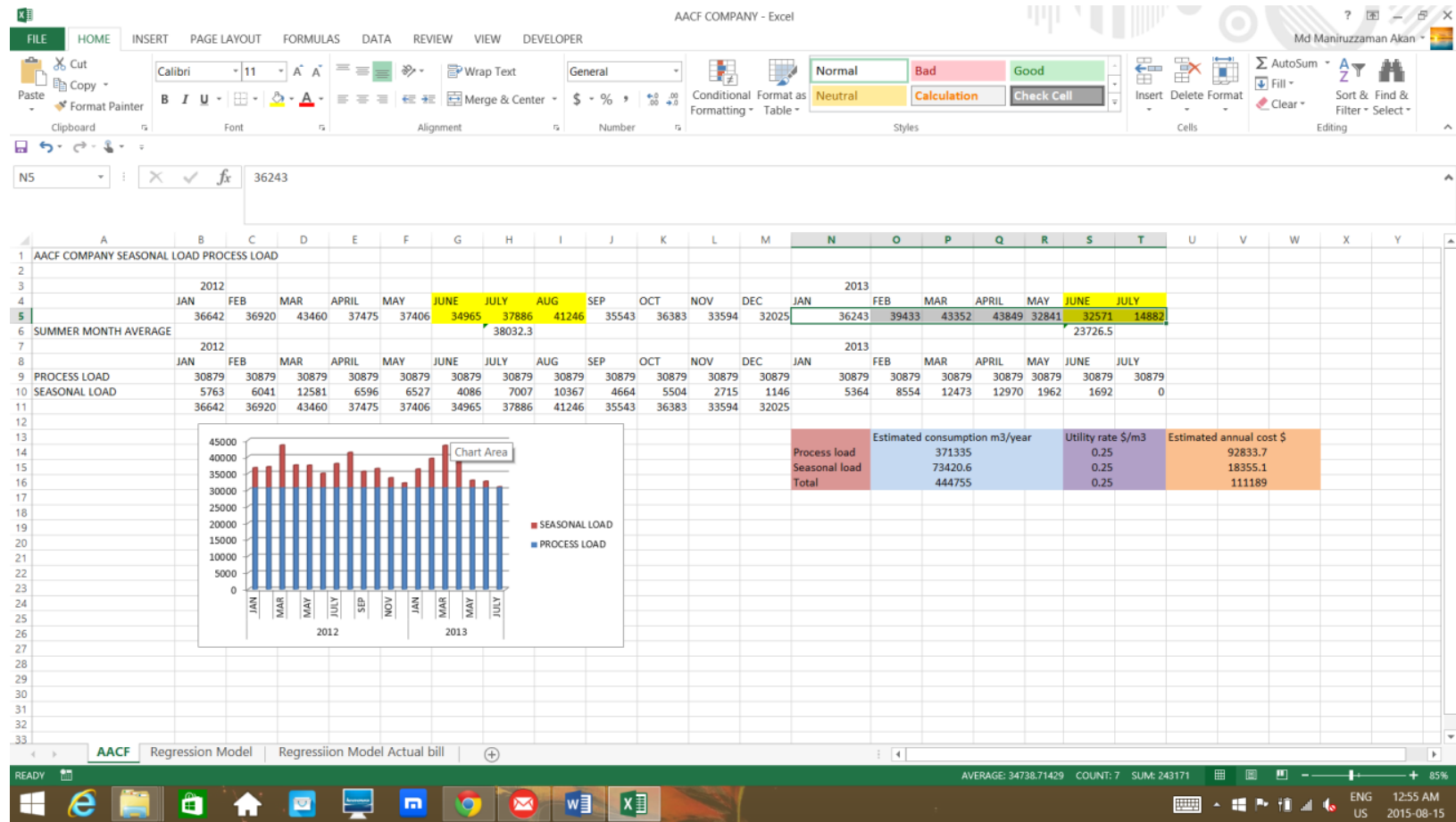

\section{AAMP}

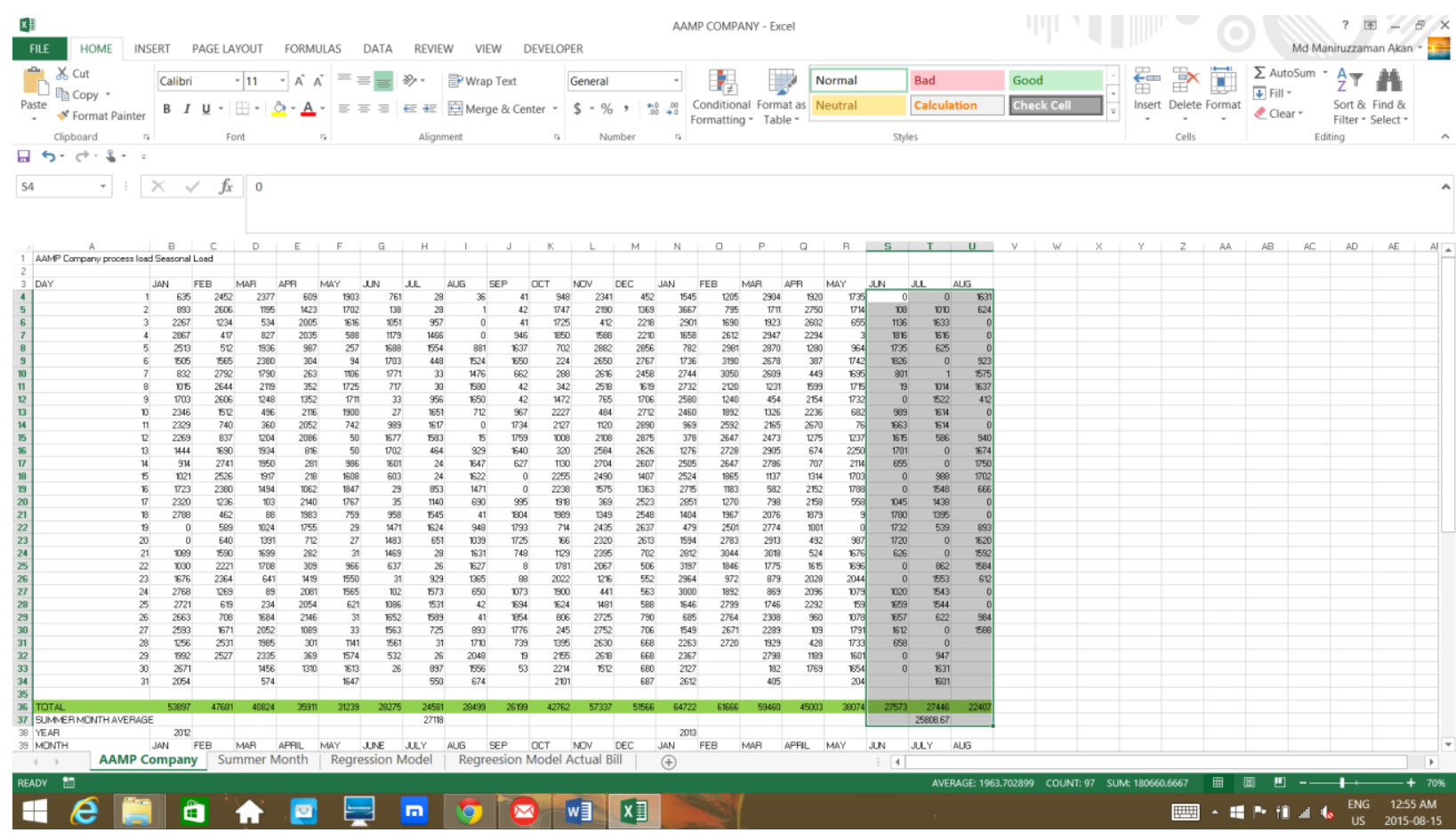




\section{AABN}

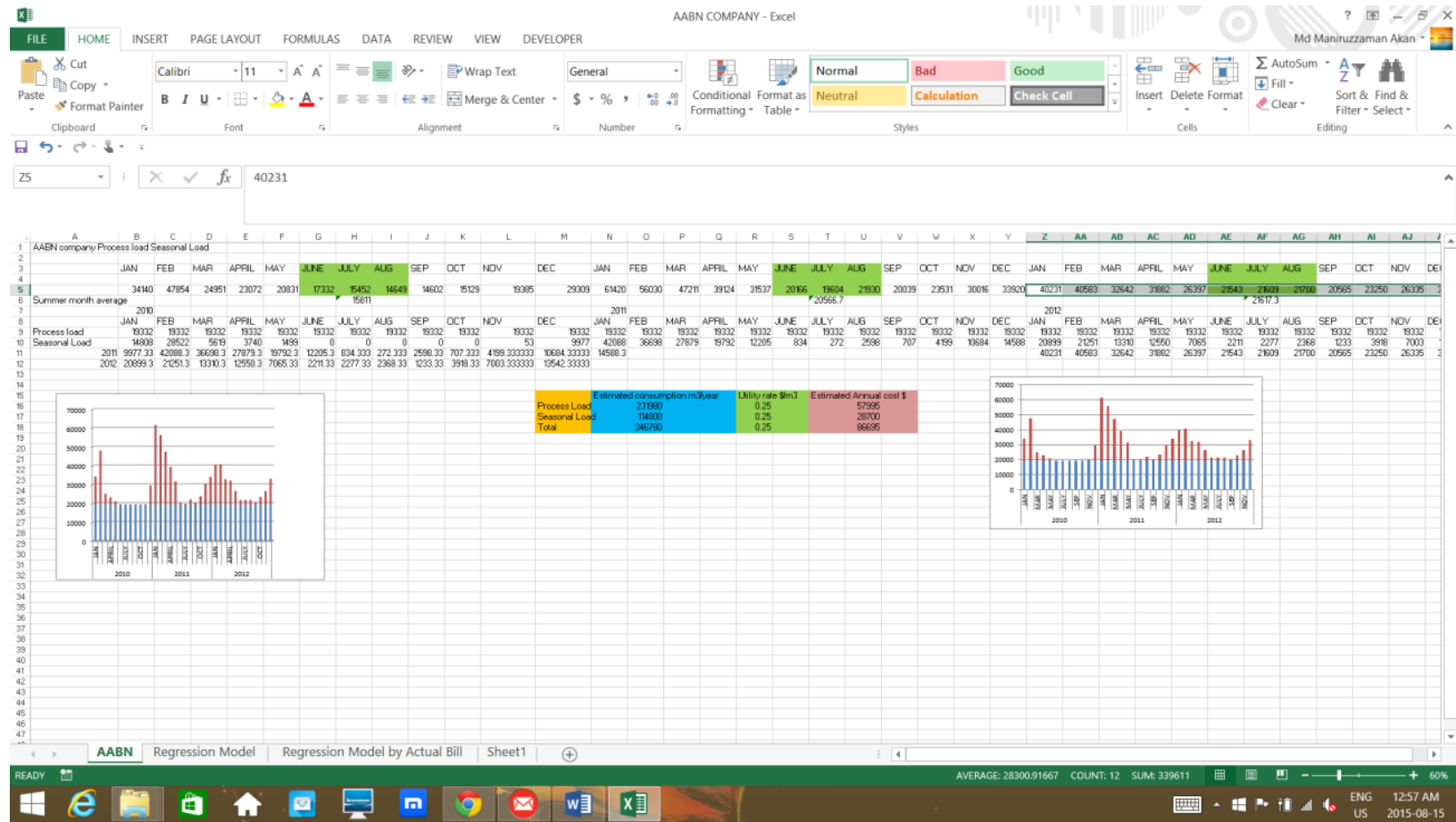

\section{AASPEC}

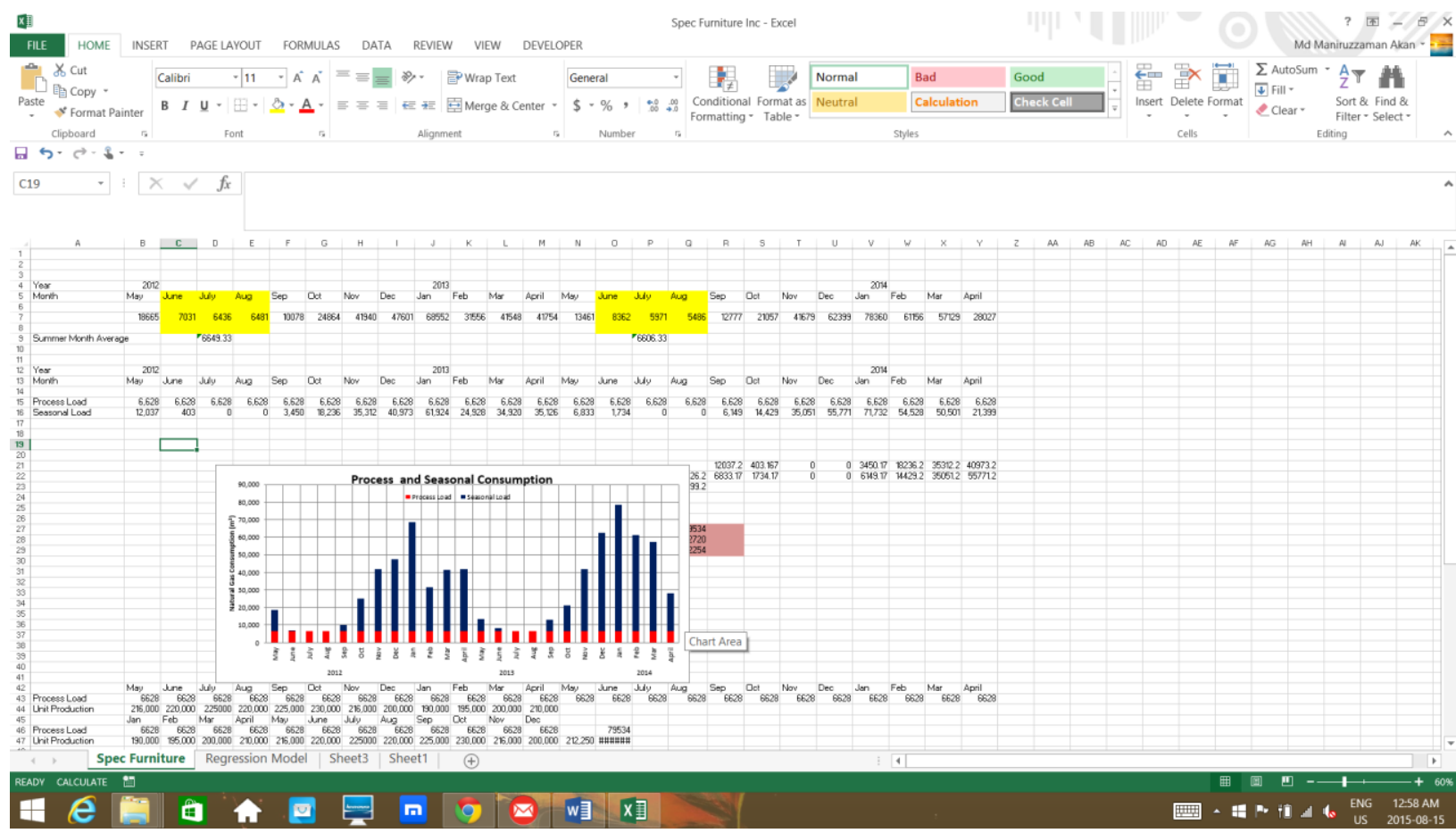




\section{AAWIL}

《)

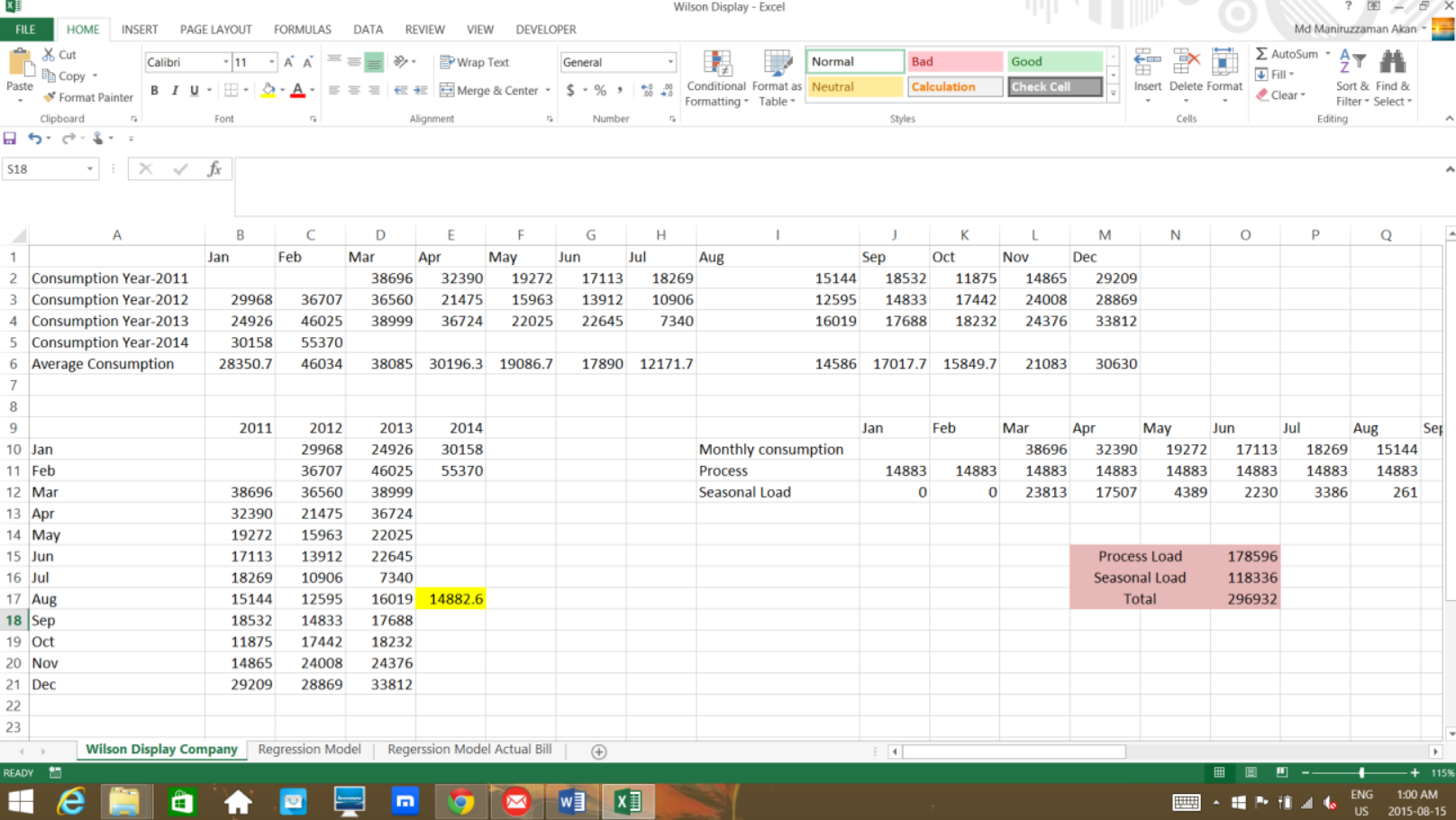

\section{D-78}

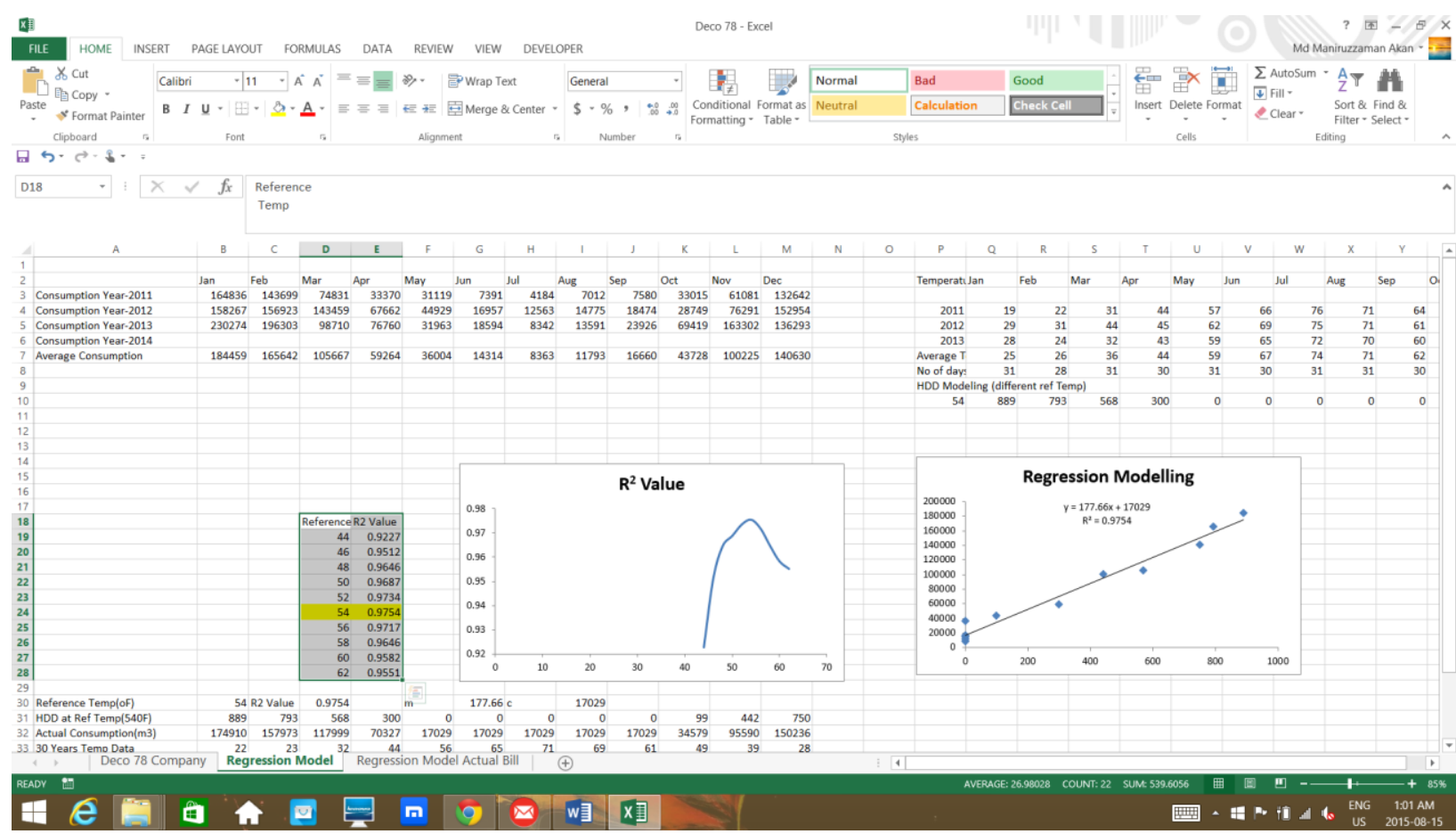




\section{D-225}

a

FILE HOME INSERT PAGELAYOUT FORMULAS DATA REVIEW VIEW DEVELOPER

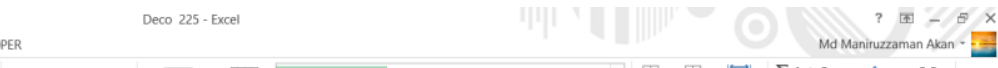

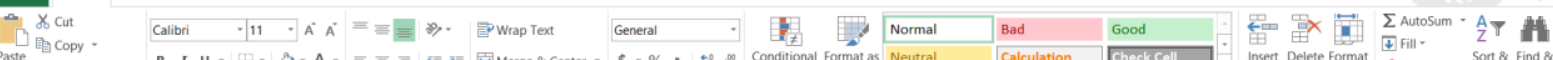

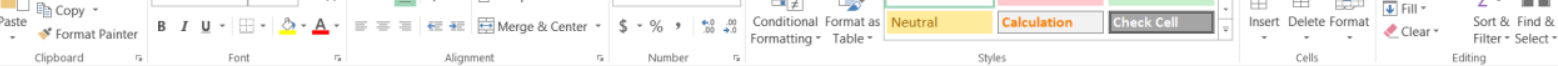
a clipboard

D13 $: X \vee f_{x}$ Reference

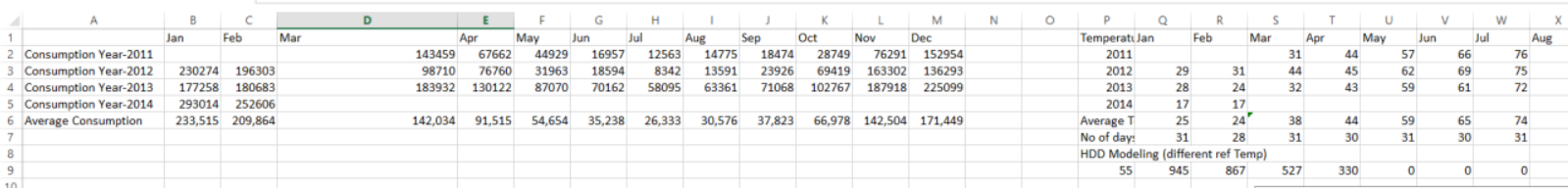

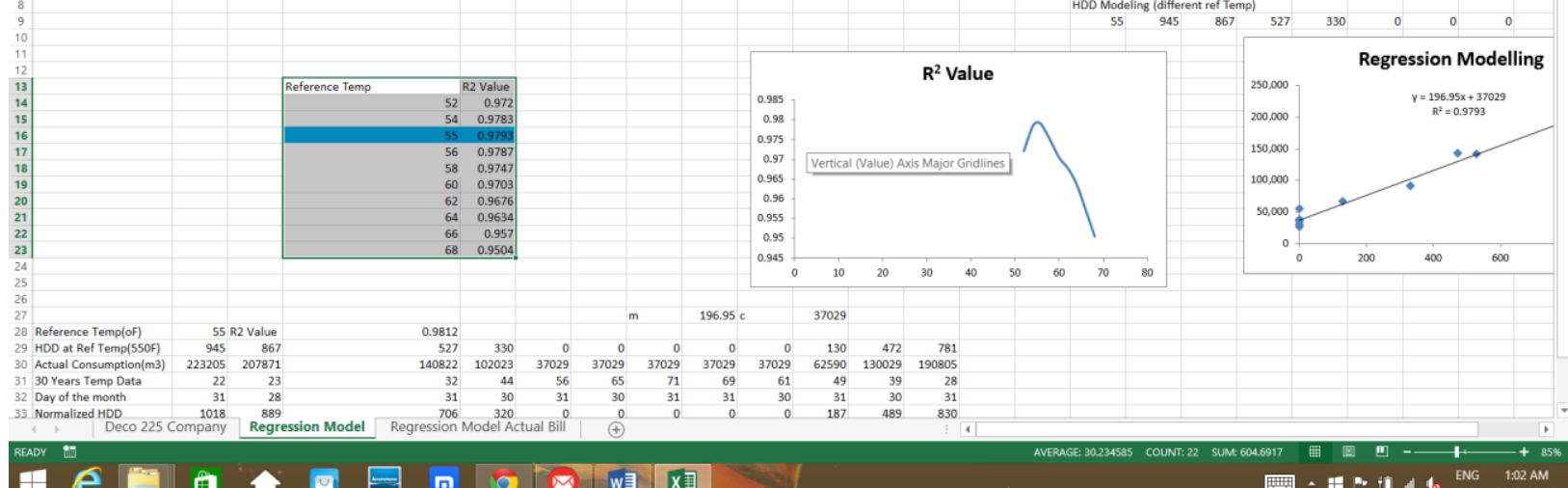

\section{AAACT}

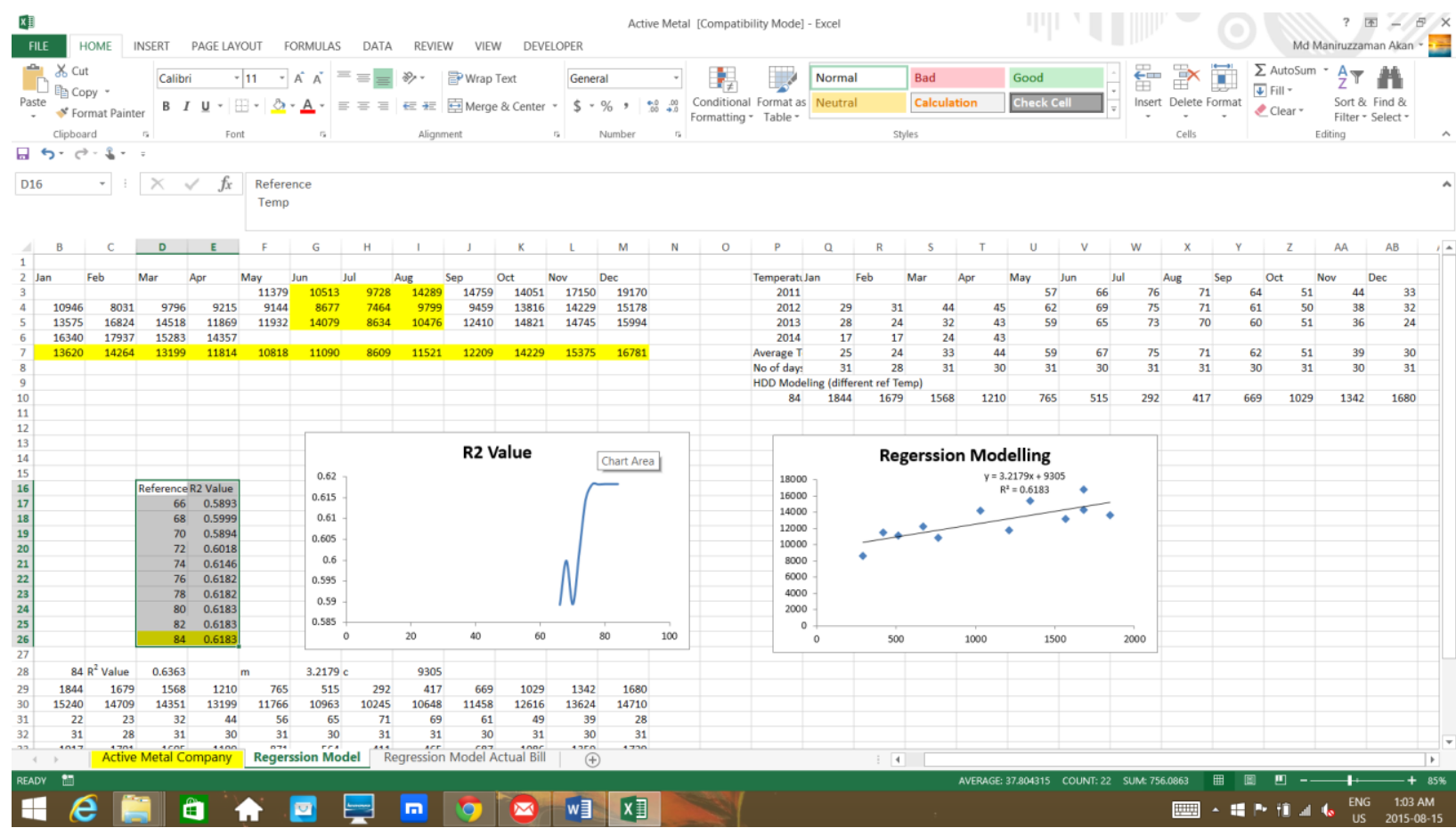




\section{Appendix G}

Price of Variable Frequency Drive

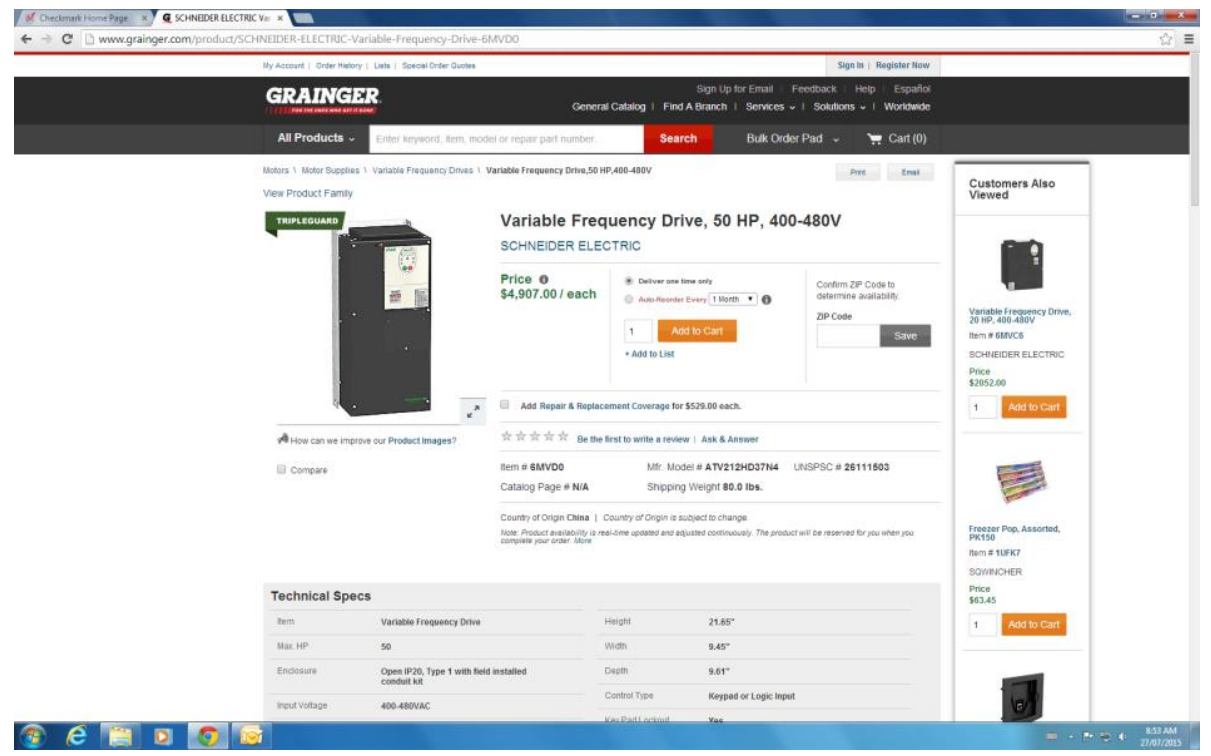

Source: http://www.grainger.com/product/SCHNEIDER-ELECTRIC-Variable-Frequency-Drive-6MVD0

This price is changing based on negotiation and service.

1. Price of insulation
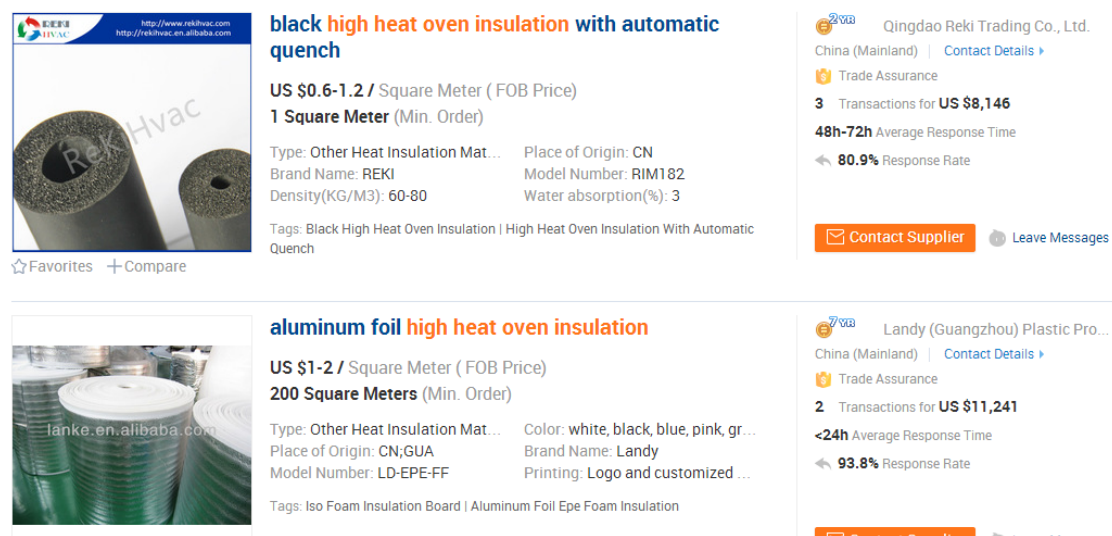

aluminum foil high heat oven insulation US \$1-2/ Square Meter (FOB Price)

200 Square Meters (Min. Order)

Type: Other Heat Insulation Mat... Color: white, black, blue, pink, gr...

Place of Origin: $\mathrm{CN} ; \mathrm{GUA} \quad$ Brand Name: Landy

Model Number: LD-EPE-FF Printing: Logo and customized

Tags: Iso Foam Insulation Board | Aluminum Foil Epe Foam Insulation

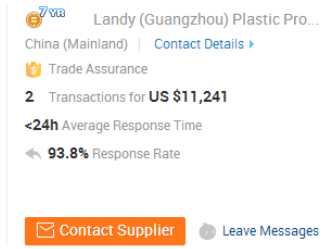

认Favorites + Compare

Source: http://www.alibaba.com/showroom/high-heat-oven-insulation.html

This price is changing based on quantity, port of shipment and tax rate. 


\section{Appendix H}

2. Wages of Electrical License Technician

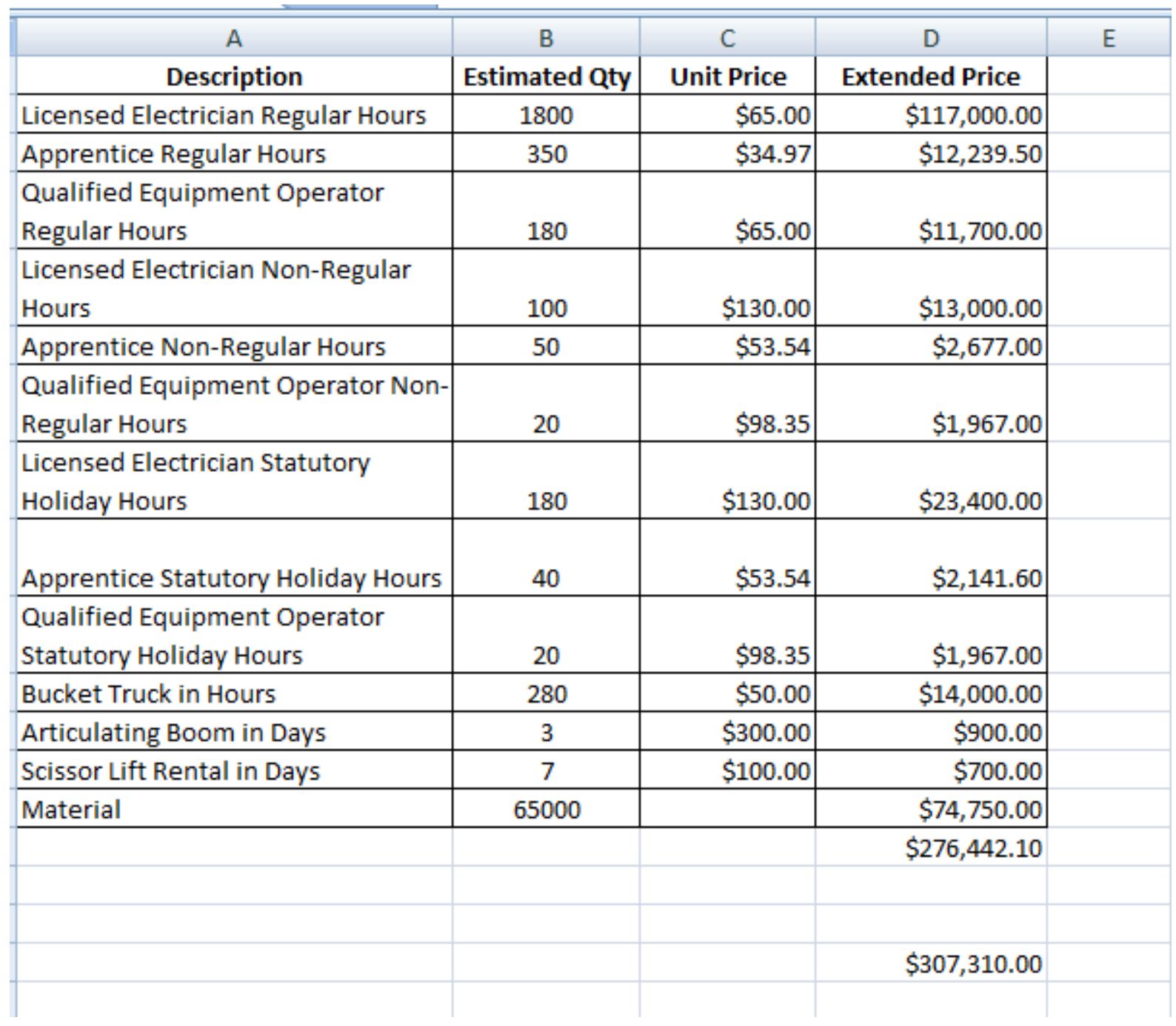

Source:

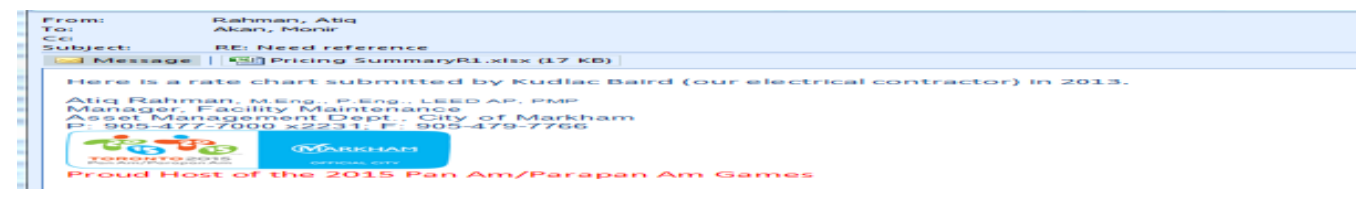

This wage rate is an approximate which is subject to changes by experience and craftsmanship. 


\section{Appendix I}

\section{HST}

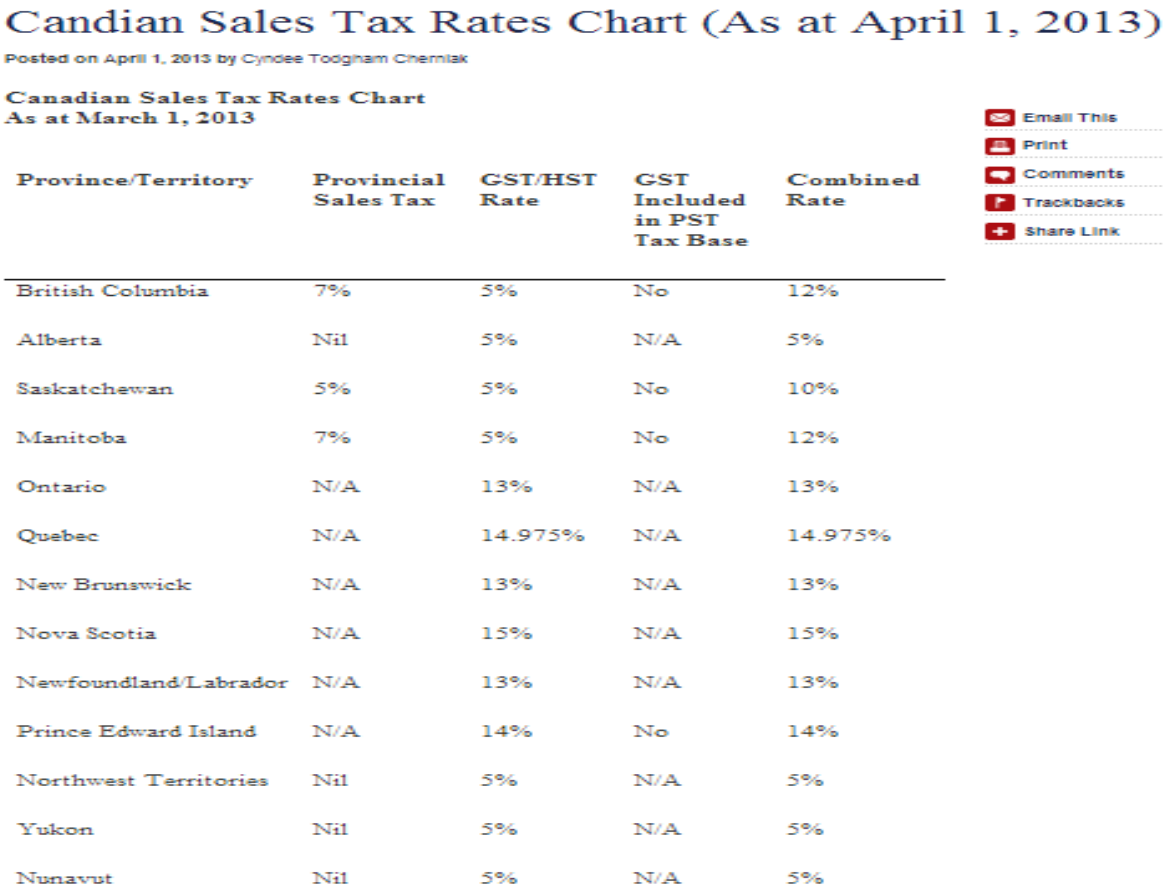

Source: http://www.thehstblog.com/2013/04/articles/gst-general-1/candian-sales-tax-rates-chart-as-atapril-1-2013/

HST rate shows 13\%, which is subject to change by Provincial and Federal Government' policy

1. Natural gas billing rate by Enbridge as a flat rate considered @0.25/ $\mathrm{m}^{3}$

\begin{tabular}{|c|c|c|c|c|c|}
\hline A & B & $\mathrm{C}$ & D & $\mathrm{E}$ & $\mathrm{F}$ \\
\hline Location: & City of Markham-> $920000033464->910010762233$ [910010762233] & & & & \\
\hline Time: & $27 / 07 / 201514: 19$ & Commodity: & Natural Gas & Created By: & City of Markham \\
\hline Year & Unit Cost (\$/CUBICM) & & & & \\
\hline 2012 & 0.18 & & & & \\
\hline 2013 & 0.193 & & & & \\
\hline 2014 & 0.244 & & & & \\
\hline 2015YTD & 0.337 & & & & \\
\hline
\end{tabular}

This rate changes little bit depending on usages and negotiation. This is an sample rate for exhibit.

Source: City of Markham, Sustainability Department. 


\section{Appendix J}

Code for Calculating Tools

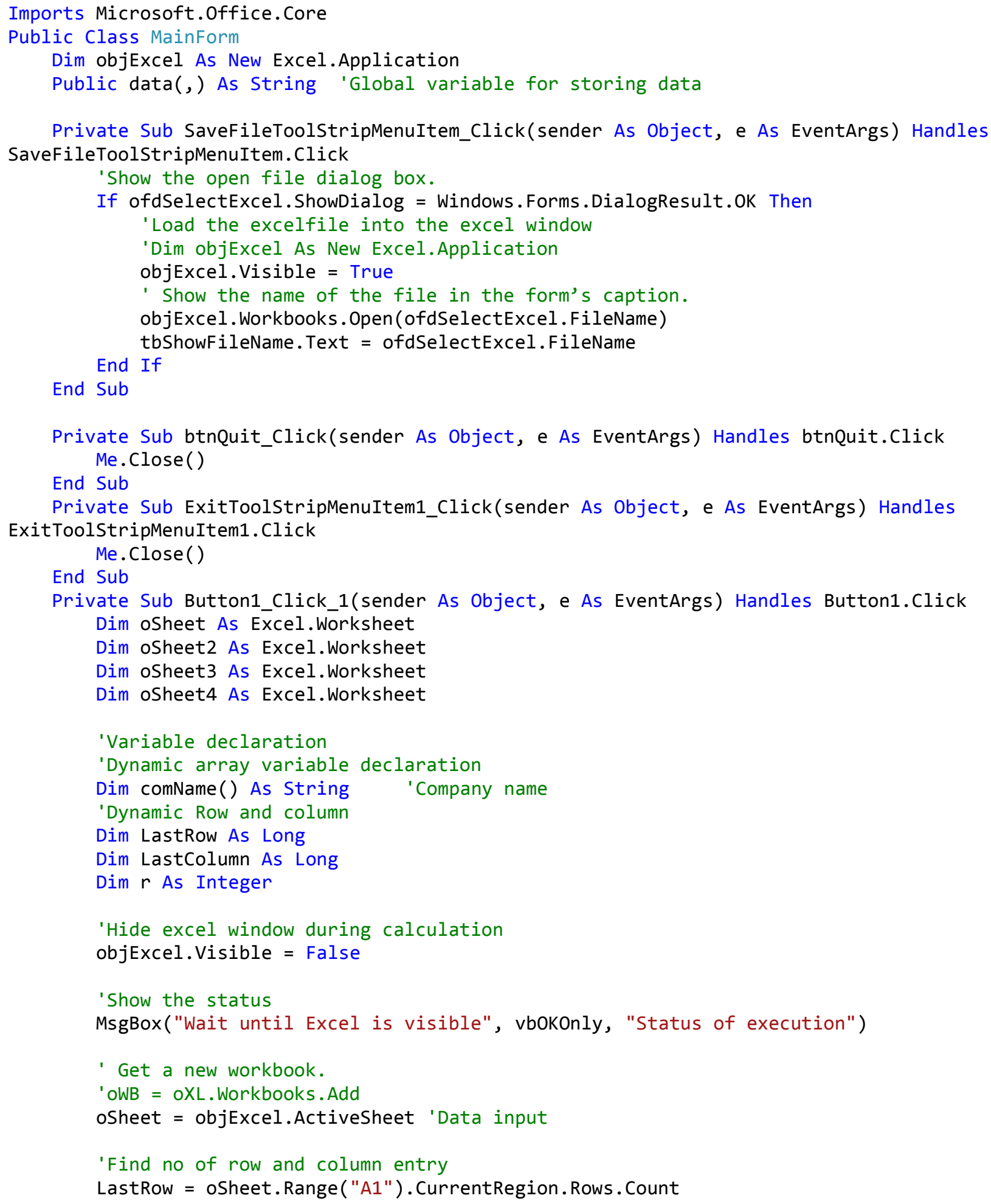


LastColumn = oSheet. Range ("A1").CurrentRegion.Columns.Count ()

'Write Company names

ReDim comName(0 To LastRow - 2) 'Dynamic allocation of cell based no. of company

entry

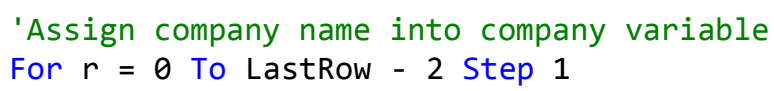




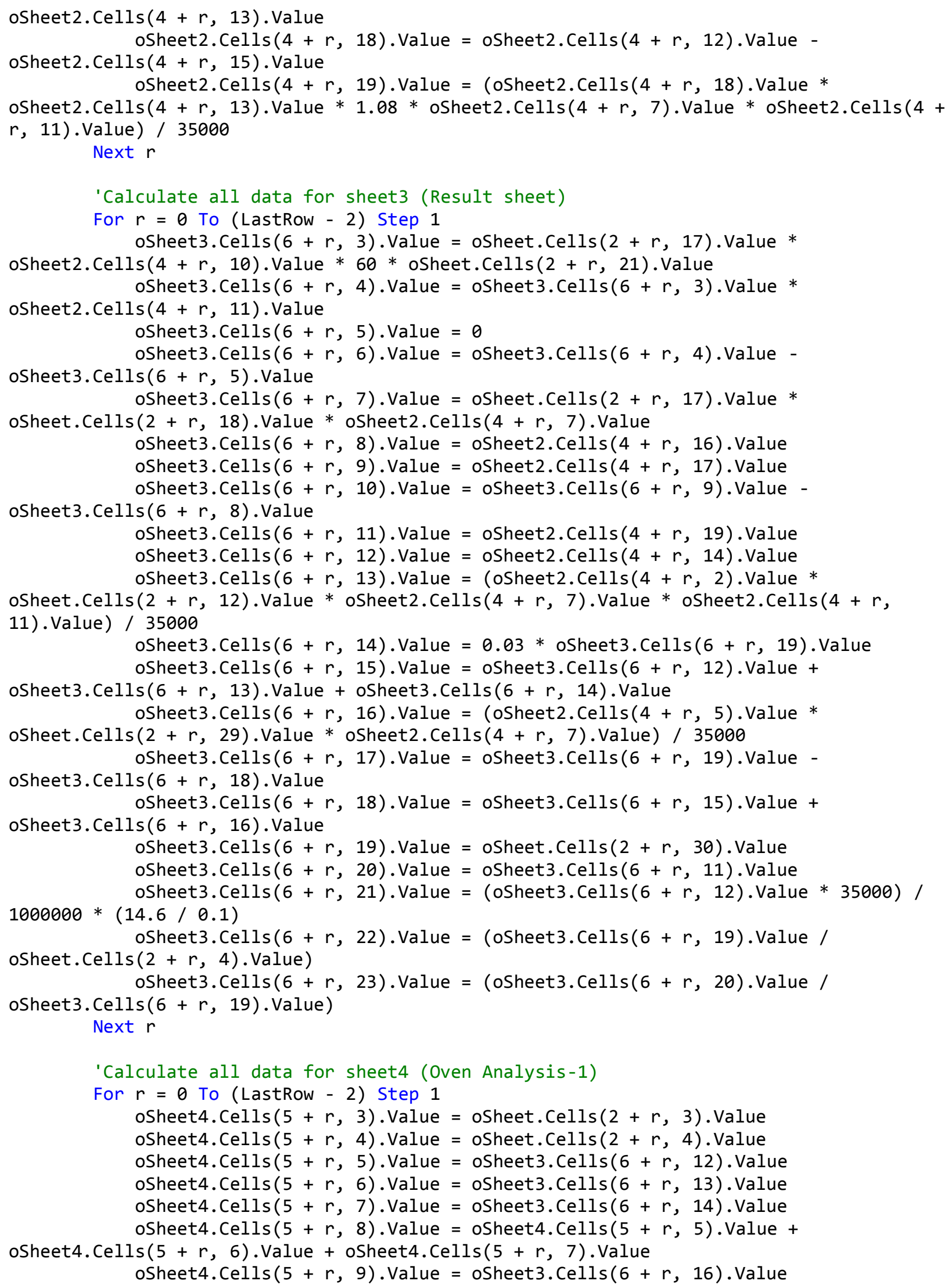




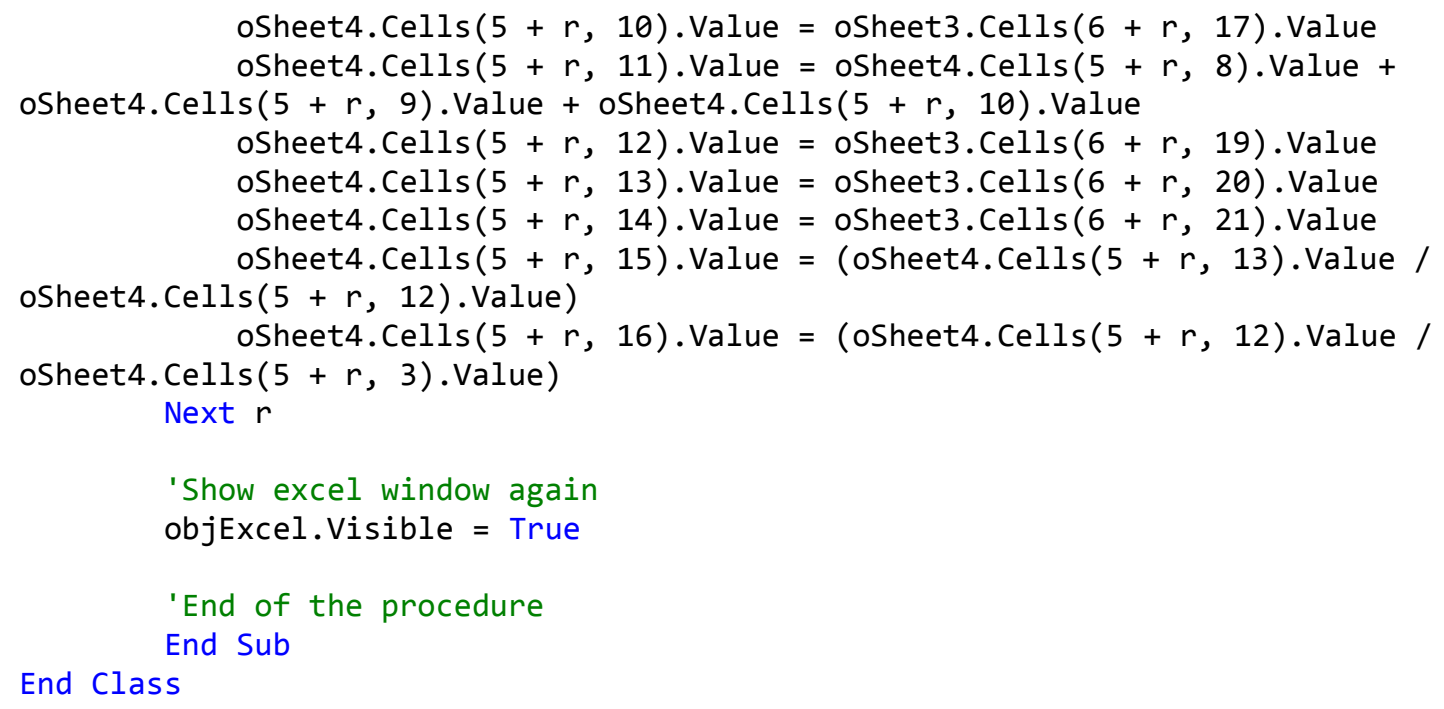




\section{Appendix K}

\section{Input screen}

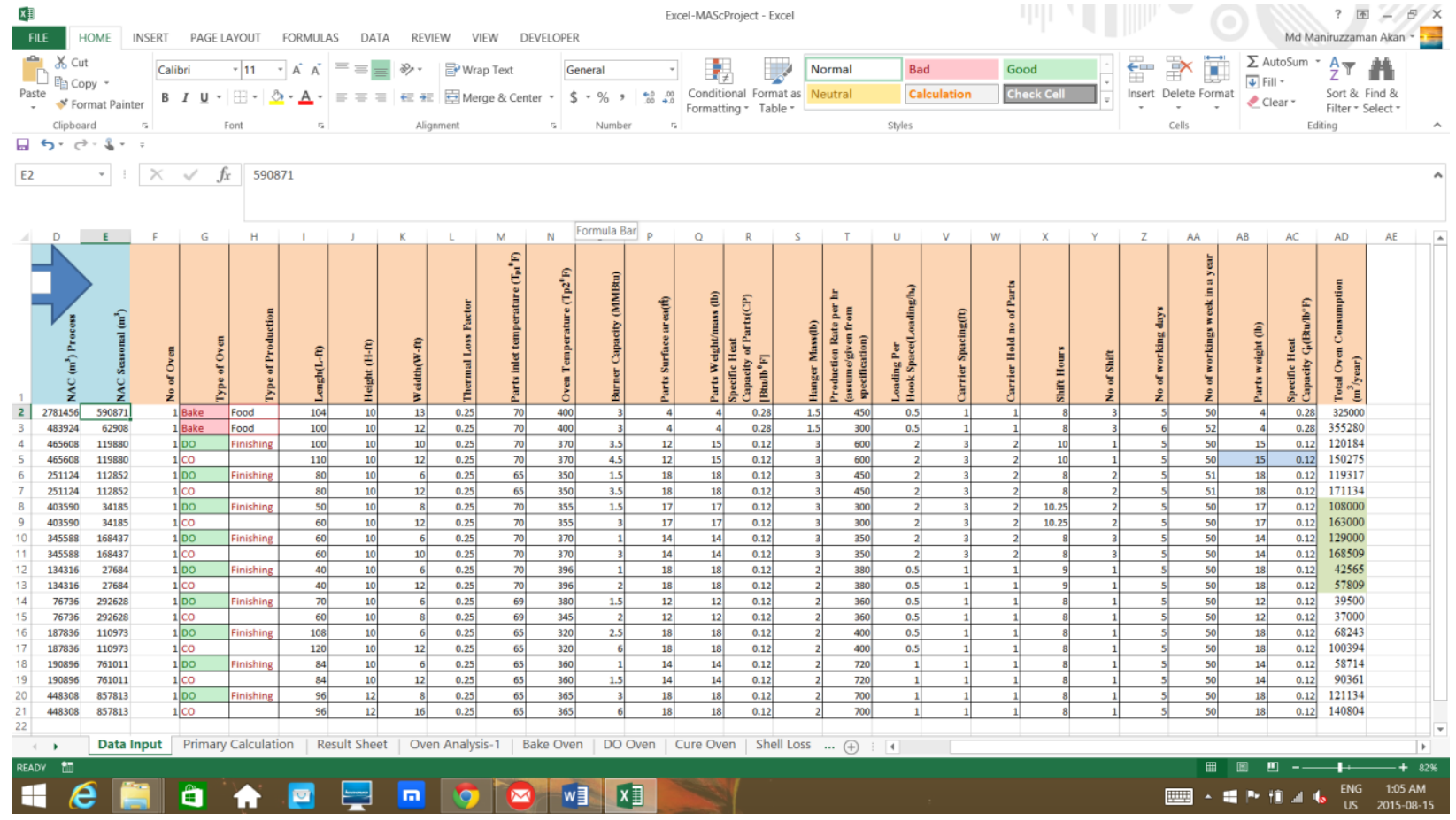




\section{Appendix L}

\section{Input screen}

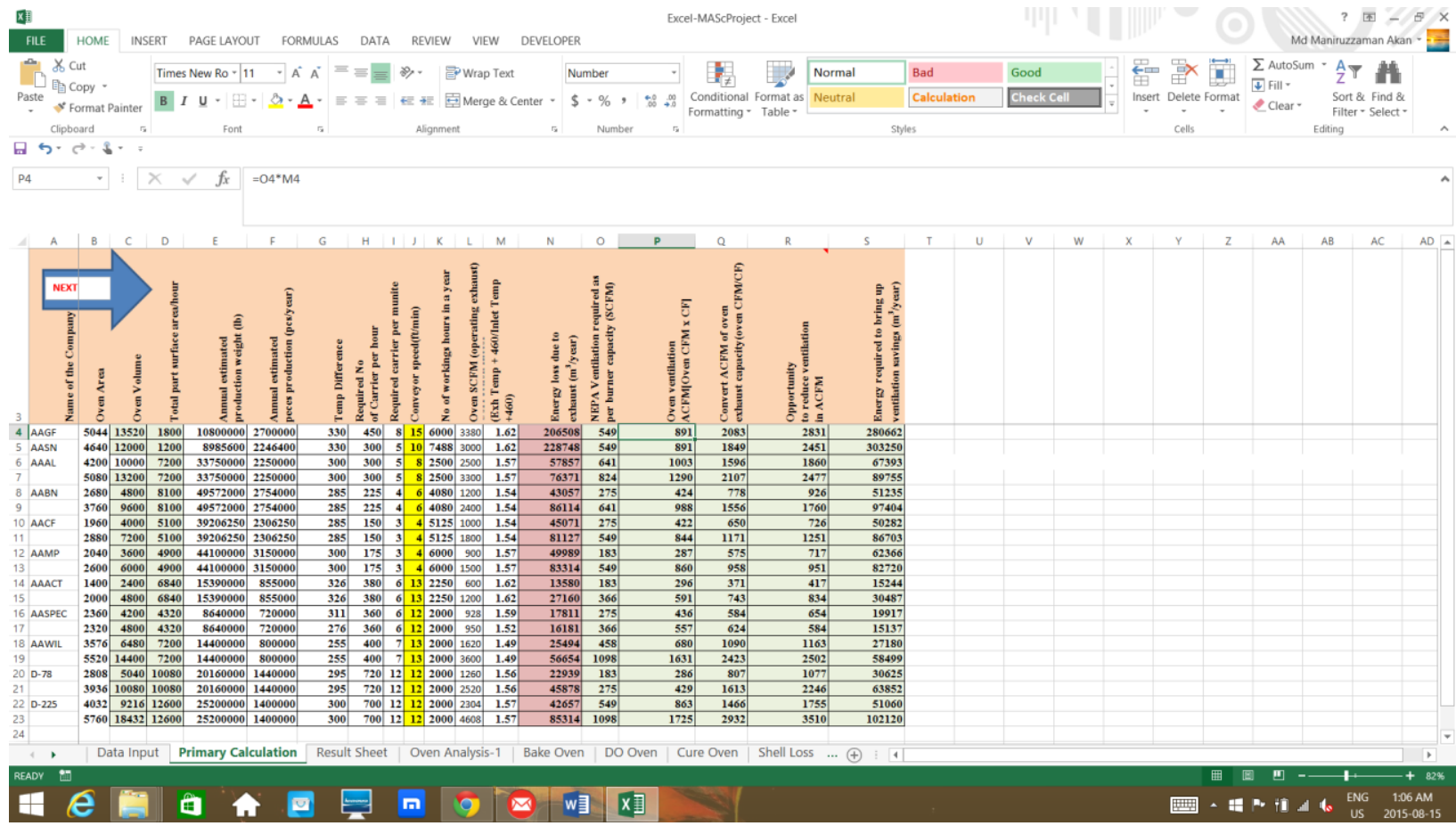




\section{Appendix M}

\section{Result screen}

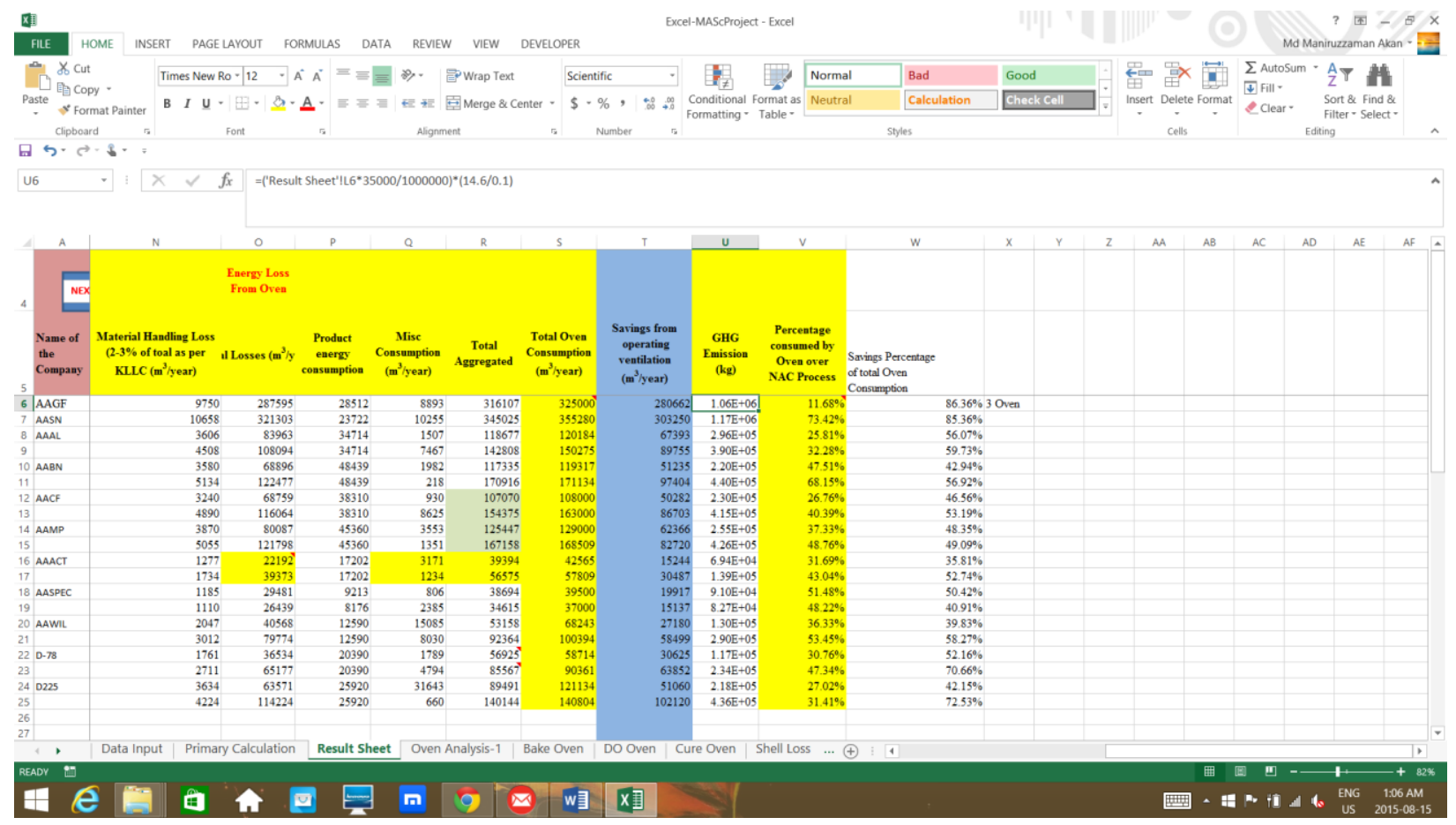




\section{Appendix N}

\section{Summary result}

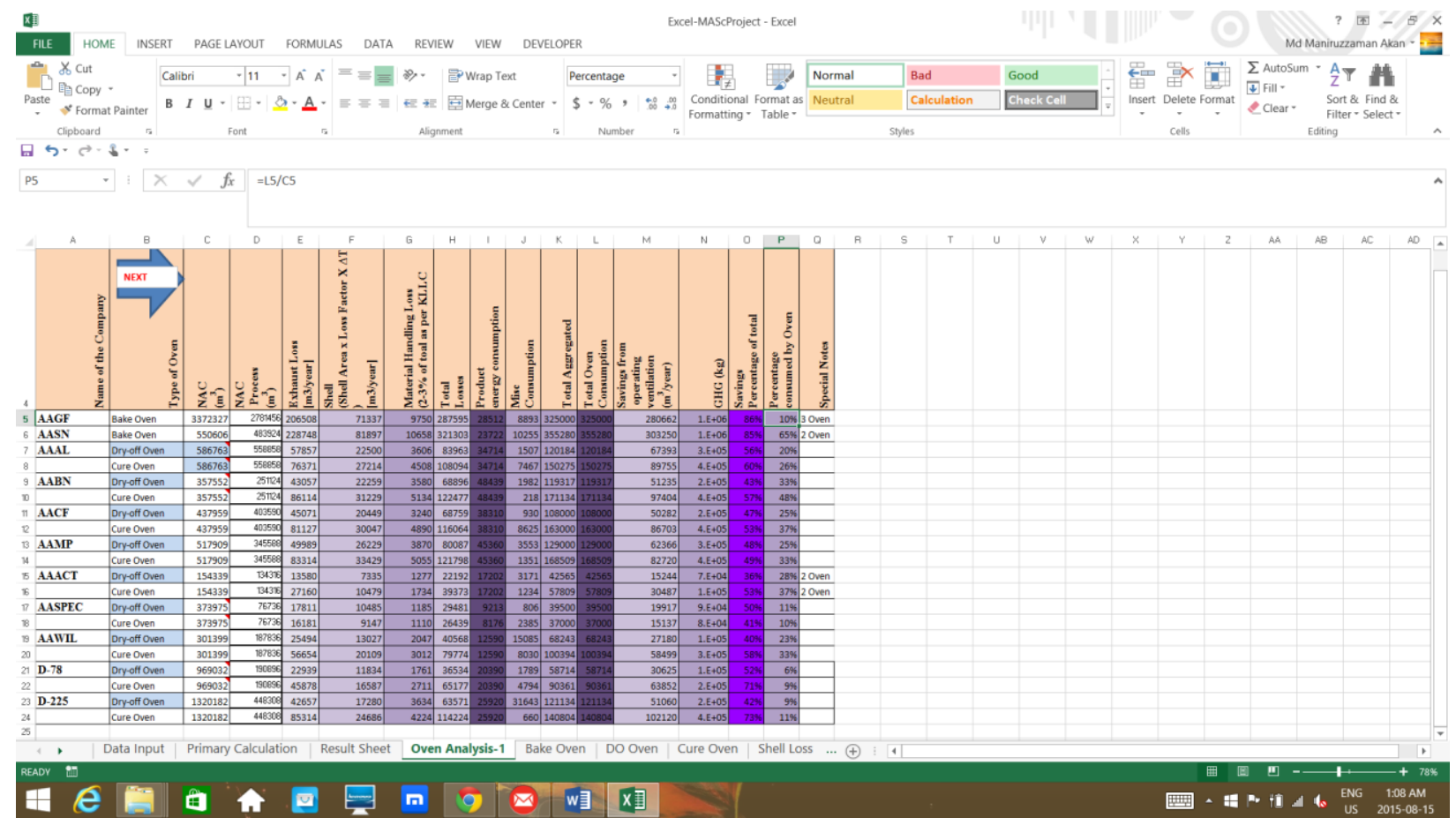




\section{Appendix 0}

\section{Calculated data for analyis}

\begin{tabular}{|c|c|c|c|c|c|c|c|c|c|c|c|}
\hline 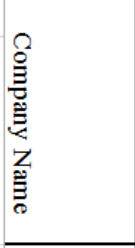 & 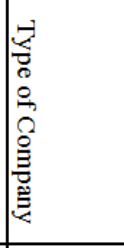 & 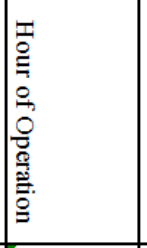 & 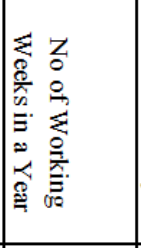 & 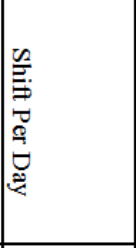 & 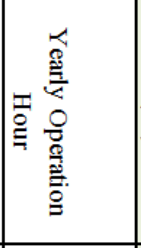 & 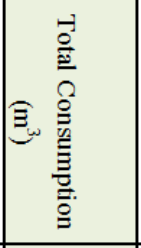 & 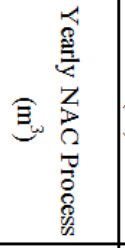 & 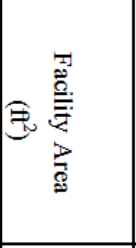 & 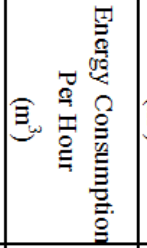 & 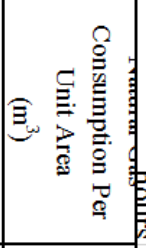 & 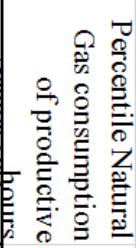 \\
\hline AAGF & Food & $24 / 5$ & 50 & 3 & 6000 & 3372327 & 2781456 & 188290 & 464 & 18 & $82 \%$ \\
\hline AASN & Food & $24 / 6$ & 52 & 3 & 7488 & 546832 & 483924 & 188045 & 65 & 3 & $88 \%$ \\
\hline AASU & Food & $18 / 6$ & 52 & 2 & 5616 & 671714 & 558858 & 60,000 & 100 & 11 & $83 \%$ \\
\hline AAWR* & Food & $24 / 5$ & 50 & 3 & 6000 & 1057007 & 902748 & 186026 & 150 & 6 & $85 \%$ \\
\hline AAKIK-10 & Packaging & $24 / 6$ & 52 & 3 & 6000 & 1008872 & 571752 & 140438 & 95 & 7 & $57 \%$ \\
\hline AAKIK-13 & Packaging & $24 / 7^{*}$ & 50 & 3 & 8400 & 734063 & 485700 & 83367 & 58 & 9 & $66 \%$ \\
\hline AAAL & Finishing & 05 -Oct & 50 & 1 & 2500 & 584907 & 465608 & 66142 & 186 & 9 & $80 \%$ \\
\hline $\mathrm{AACF}$ & Finishing & $20.5 / 5$ & 50 & 2 & 5125 & 437383 & 403590 & 46786 & 79 & 9 & $92 \%$ \\
\hline AAMP & Finishing & $24 / 5$ & 50 & 3 & 6000 & 514025 & 345588 & 67604 & 58 & 8 & $67 \%$ \\
\hline $\mathrm{AABN}$ & Finishing & $16 / 5$ & 51 & 2 & 4000 & 363976 & 251124 & 10327 & 63 & 35 & $69 \%$ \\
\hline AASPEC & Finishing & 05-Dec & 50 & 1 & 3000 & 369364 & 76736 & 71722 & 26 & 5 & $21 \%$ \\
\hline AAWIL & Finishing & 05-Aug & 50 & 1 & 2000 & 298809 & 187836 & 110270 & 94 & 3 & $63 \%$ \\
\hline AADEC-78 & Finishing & 05-Aug & 50 & 1 & 2000 & 951907 & 190896 & 230453 & 95 & 4 & $20 \%$ \\
\hline AADEC-22 & Finishing & 05-Aug & 50 & 1 & 2000 & 1306121 & 448308 & 213668 & 224 & 6 & $34 \%$ \\
\hline AAACT & Finishing & $05-\mathrm{Sep}$ & 50 & 1 & 2250 & 161682 & 134316 & 10327 & 60 & 16 & $83 \%$ \\
\hline
\end{tabular}

\begin{tabular}{|c|c|c|c|c|c|c|c|c|c|c|c|c|}
\hline 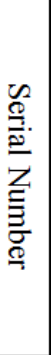 & 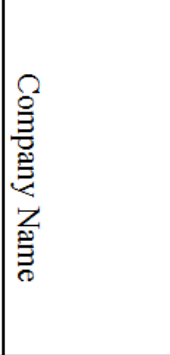 & 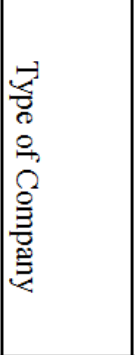 & 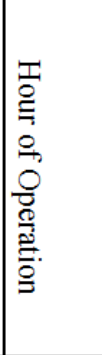 & 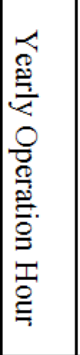 & 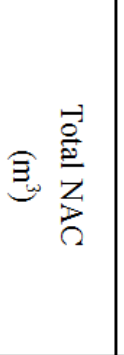 & 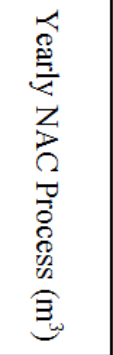 & 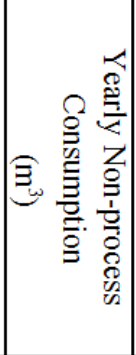 & 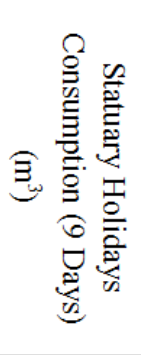 & 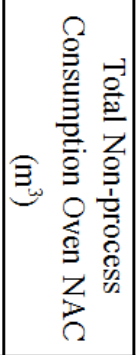 & 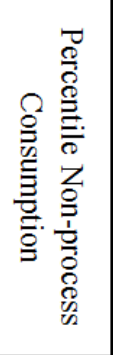 & 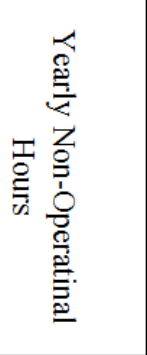 & 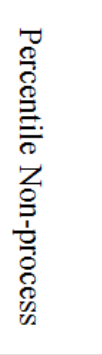 \\
\hline 1 & AAGF & Food & $24 / 5$ & 6000 & 3372327 & 2781456 & 633043 & 43229 & 676272 & $20.05 \%$ & 1,200 & 0.20 \\
\hline 2 & AASN & Food & $24 / 6$ & 7488 & 546832 & 483924 & 59841 & 8663 & 68504 & $12.53 \%$ & 973 & 0.13 \\
\hline 3 & AAKIK-10 & Packaging & $24 / 6$ & 6000 & 1008872 & 571752 & 120760 & 12987 & 133747 & $13.26 \%$ & 809 & 0.13 \\
\hline 4 & AAKIK-13 & Packaging & $24 / 7$ & 8400 & 734063 & 485700 & 0 & 13014 & 13014 & $1.77 \%$ & 173 & 0.02 \\
\hline 5 & AAAL & Finishing & "10/5" & 2500 & 584907 & 465608 & 77617 & 13663 & 91280 & $15.61 \%$ & 394 & 0.16 \\
\hline 6 & $\mathrm{AACF}$ & Finishing & $20.5 / 5$ & 5125 & 437383 & 403590 & 52919 & 4567 & 57486 & $13.14 \%$ & 663 & 0.13 \\
\hline 7 & AAMP & Finishing & $24 / 5$ & 6000 & 514025 & 345588 & 50389 & 5017 & 55406 & $10.78 \%$ & 676 & 0.11 \\
\hline 8 & AABN & Finishing & $16 / 5$ & 4000 & 363976 & 251124 & 26714 & 3389 & 30103 & $8.27 \%$ & 320 & 0.08 \\
\hline 9 & AADEC-225 & Finishing & "8/5" & 2000 & 1306121 & 448308 & 248520 & 24590 & 273110 & $20.91 \%$ & 420 & 0.21 \\
\hline 10 & AASPEC & Finishing & "12/5" & 3000 & 369364 & 76736 & 72851 & 8785 & 81636 & $22.10 \%$ & 660 & 0.22 \\
\hline
\end{tabular}




\section{Appendix P}

List of Audited Company and their Acronym

\begin{tabular}{|c|c|c|c|}
\hline $\begin{array}{c}\text { Acronym of } \\
\text { Company }\end{array}$ & Company Name & Type of Company & Type of Oven \\
& & & \\
\hline AAGF-B & Griffith Laboratories & Food Processing & Bake oven \\
\hline AASN-B & Son Bakery & Food Processing & Bake oven \\
\hline AAAL-D & ACL Auto Coating Ltd. & Finishing Process Company & Dry-off oven \\
\hline AAAL-C & ACL Auto Coating Ltd. & Finishing Process Company & Cure oven \\
\hline AABN-D & Broan-NuTon & Finishing Process Company & Dry-off oven \\
\hline AABN-C & Broan-NuTon & Finishing Process Company & Cure oven \\
\hline AACF-D & Calorific Inc. & Finishing Process Company & Dry-off oven \\
\hline AACF-C & Calorific Inc. & Finishing Process Company & Cure oven \\
\hline AAMP-D & M\&P Co & Finishing Process Company & Dry-off oven \\
\hline AAMP-C & M\&P Co & Finishing Process Company & Cure oven \\
\hline AAACT-D & Active Metal Inc. & Finishing Process Company & Dry-off oven \\
\hline AAMP-C & Active Metal Inc. & Finishing Process Company & Cure oven \\
\hline AASPEC-D & Spec Furniture Inc. & Finishing Process Company & Dry-off oven \\
\hline AASPEC-D & Spec Furniture Inc. & Finishing Process Company & Cure oven \\
\hline AAWIL-D & Wilson Display Inc. & Finishing Process Company & Dry-off oven \\
\hline AAWIL-C & Wilson Display Inc. & Finishing Process Company & Cure oven \\
\hline D-78-D & Deco Automotive-Brampton & Finishing Process Company & Dry-off oven \\
\hline D-78-C & Deco Automotive-Brampton & Finishing Process Company & Cure oven \\
\hline D-225-D & $\begin{array}{c}\text { Deco Automotive- } \\
\text { Etobicoke }\end{array}$ & Finishing Process Company & Dry-off oven \\
\hline D-225-C & $\begin{array}{c}\text { Deco Automotive- } \\
\text { Etobicoke }\end{array}$ & Finishing Process Company & Cure oven \\
\hline
\end{tabular}




\section{References}

[1] Seens, D.L. (March 2013). "Small and Medium-Sized Enterprises Growth Study: Actual vs. Sustainable Growth." Small Business Branch Research and Analysis Directorate.

[2] Mandil, C. (2007). Tracking Industrial Energy Efficiency and $\mathrm{CO}_{2}$ Emissions. 75739 Paris Cedex 15, France.: IEA.

[3] Industry Canada. (2013). Retrieved August 25, 2014, from Industry Canada website: Key Small Business Statistics - August 2013; How do we define and categorize business? http://www.ic.gc.ca/eic/site/061.nsf/eng/02803.html

[4] Axsen, J., Nyboer, J., \& Bataille, B. C. (2005). Goods-Producing Small to Medium-Sized Enterprises: Energy end use and efficiency potentials. Burnaby, BC: Canadian Industrial Energy End-use Data and Analysis Centre; Simon Fraser University

[5] Natural Resources Canada. (2013). Industrial Consumption of Energy (ICE) Survey: Summary report of energy use in the Canadian manufacturing sector 1995-2011, 1165 Kenaston street, PO Box 9809, StnT, Ottowa, ON, K1G GS1

[6] Trombley, D. (2014). One Small Step for Energy Efficiency: Targeting small and mediumsized manufacturers. American council for an energy-efficient economy. $52914^{\text {th }}$ Street NW, Suite 600, Washington, DC, 20045

[7] Kostka, G., Moslener, U. \& Andreas, J. (n.d.). Barriers to Energy Efficiency Improvement: Empirical evidence from small-and -medium-sized enterprises in China. Frankfurt school of finance and management, Sonnemann St, 9-11 Frankfurt am Main 60314

[8] Baig, A.A. (2014). Analysis of natural gas consumption and energy savings measures for small and medium-sized industries in the Greater Toronto Area. Ryerson University, Toronto, Canada

[9] Investopedia. (n.d.). Investopedia online dictionary. Retrieved from http://www.investopedia.com/sustainablegrowthrate.asp

[10] Ontario Power Authority. (n.d.). Save on energy. Retrieved from https://www.saveonenergy.ca/Business/Program-Overviews/Audit-Funding.aspx

[11] Institute of Electrical and Electronics Engineers (IEEE). (n.d.). Dictionary.com. Retrieved September 14, 2014, from Dictionary.com Unabridged.: http://dictionary.reference.com/browse/energy audit

[12] Canadian Industry Program for Energy Conservation. (n.d.). Energy Savings Toolbox - An Energy Audit Manual and Tool. Retrieved from National Resources Canada: 
http://www.nrcan.gc.ca/sites/www.nrcan.gc.ca/files/oee/pdf/publications/infosource/pub/cipec/en ergy-audit-manual-and-tool.pdf

[13] Jamaludin, A., M, N. (2013). Energy Audit and Prospective Energy Conservation. Energy Audit and Conservation, 31, 158-172.

[14] Sharma., R.A. (2006). Electrical India (Vol. 46). Secunderabad, Andhra Pradesh, India: Master Consultancy \& Productivity Pvt. Ltd.

[15] Natural Resources Canada. (n.d.). Energy conservation vs. energy efficiency. Retrieved from http://www.nrcan.gc.ca/enrgy/efficiency/buildings/eeb/key/3969

[16] An ISGAN glossary definition. (n.d.). Definition: demand side management. Retrieved from http://www.en.openei.org/wiki/definition_demand_side_managemnt

[17] Bazari, Z., (2007). Ship energy performance benchmarking: methodology and application. Journal of Marine Engineering and Technology, No. A9 2007.

[18] Capehart, B., et al. (2011). Comprehensive Five Days Training Program for Certified Energy Managers, Association of energy engineers, 4024 Pleasantdale road, Suite 420, Atlanta, Georgia USA.

[19] Agrawal, S. (2005). Heat and Mass Transfer. Anshan limited, Tunbridge wells, Kent, UK

[20] InfraSource Inc. (n.d.). Powder coating process. Retrieved from http;//www.infrasourceus.com

[21] Society of Manufacturing Engineers. (n.d.). Painting \& Powder Coating. www.sme.org. Retrieved from http://manufacturing.stanford.edu/processes/Painting\&PowderCoating.pdf

[22] Auto Coat Engineering (India) P. Ltd. (n.d.). Industrial Oven [Brochure]. Retrieved from http://www.autocoatindia.com/industrial-oven.htm

[23] Fawer, B. (n.d.). Powder coating magazine: Cure dynamics of powder coatings. CSC publishing, powder coating. from http://www.pcoating.com/Content/getArticle.aspx?ItemID=540d403c-4dd2-49cc-8362a2db44b6a913\&Subject=Powder+coatings

[24] Aquini, R. (n.d.). Powder coating magazine: Reducing energy use in powder coating systems. CSC publishing, powder coating. Retrieved from http://www.pcoating.com/Content/getArticle.aspx?ItemID=af0cc7d8-9cc4-4545-98bc54401cddebf6

[25] Aquino, R. (n.d). Reducing energy use in powder coating system. Energy reduction technical article. CSC publishing, Powder coating 
[26] Kraft, K.N. (1996). Curing oven basics. Modern machine shop. Garner business media Inc. 2015. Retrieved from http:// www.pfonline.com/article/curing-oven-baseline

[27] Fels, M. \& Reynolds, C. (1994) "Three-Point HO/CO PRISM in Advanced Version of PRISM," Report for Advanced PRISM Project, Center for Energy and Environmental Studies, Princeton University, Princeton,

[28] http://www.graphpad.com/scientific-software/prism/\#7 (Inc., 2014)

[29] Kulkarni, J. (2006). Energy, Economic and Environmental Impacts of the Delaware LowIncome Weatherization Assistance Program. Newark, DE 19716, United States: Center for Energy and Environmental Policy,University of Delaware.

[30] Fels, M. ed. (1986) "Measuring Energy Savings: The Scorekeeping Approach," Special PRISM Issue of Energy and Buildings, 9, \#1-2, 180 pages

[31] Fels, M. (1986) "PRISM: An Introduction," Energy and Buildings 9, \#1-2, pp. 5-18

[32] Reynolds, C. (1987) "PRISM: A Tool for Tracking Retrofit Savings," Energy Auditor and Retrofitter, Nov/Dec, pp. 27-36

[33] Ghajarkhosravi, M. (2010). "Utility Benchmarking and Potential Savings of Multi-Unit Residential Buildings (MURBs) in Toronto,” Ryerson University

[34] BizEE, Energy Lens: Degree Days - Handle With Care! (2014). Retrieved July 18, 2014, from Energy Lens: http://www.energylens.com

[35] Day, T. (2006). Degree days: theory and application. London: Jacquiline Balich. ISBN -13:

987-1-3287-76-7

[36] Cho, H., \& K, G. (2010). Energy Saving Impact of ASHRAE 90.1 Vestibule Requirements: Modeling of Air Infiltration through Door Openings. Richland, Washington 99352: Pacific Northwest National Laboratory.

[37] Thornton. B.A., Rosenberg. M.I., Richman, E.E., Wang, W., Xie, Y., Zhang. J., Cho, H., Mendon, V.V., Athalye, R.A., \& Liu, B. (2011). Achieving the 30\% Goal: Energy and Cost Savings Analysis of ASHRAE Standard 90.1-2010. Washington 99352: Pacific Northwest National Laboratory. Retrieved from http://www.energycodes.gov/sites/default/files/documents/BECP_Energy_Cost_Savings_STD20 10_May2011_v00.pdf

[38] Weimin Wang, Weimin.(2006). Floor shape optimization for green building design. Advanced Engineering Informatics, 363-378. 
[39] Weimin, W., Hugues, R., \& Radu, Z. (2006). A Comparative Study of Representation and Encodings for Building Shape Optimization With Genetic Algorithms. Joint International Conference on Computing and Decision Making in Civil and Building Engineering, (p. 2417). Montréal, Canada. Retrieved from http://irandanesh.febpco.com/FileEssay/civil-86-1-3-bsy\%28270\%29.pdf

[40] Michael Overcash, K. B. (2012). Estimating nonprocess energy from building energy consumption. Energy Efficiency, 6:21-33.

[41] Mohamad, N., \& Said, F. (2011). Business Management Dynamics: Solving single machine scheduling problem with common due date, Vol.1, No. 4, pp. 63-72

[42] Shabtay, D., \& G, S. (2007). Single machine batch scheduling to minimize total completion time and resource consumption costs. Journal of Scheduling, Vol-4, 255-261.

[43] Moore, J. (1986). An n Job, One Machine Sequencing Algorithm for Minimizing the Number of Late Jobs. Management Science, Vol. 15 No. 1. pp 102

[44] Guner, E., Erol, S., \& Tani, K., One machine scheduling to minimize the maximum earliness with minimum number of tardy jobs. International Journal of Production Economics. doi; PII S 0925-5273(98) 00062-0

[45] Kusiak, A, \& M, L. (2006). Modeling and optimization of HVAC energy consumption. Energy and Buildings, 220-231.

[46] Fung, A. (2012). HVAC Demand Management and Control System. Toronto, Canada: Centre for Urban Energy.

[47] ASHRAE Handbook Fundamentals 2013. (2013). N.E. Atlanta, GA 30329 : ASHRAE.

[48] Brager.S.G, \& D, d. (2001, April). Climate, Comfort \& Natural Ventilation: A new adaptive comfort standard for ASHRAE Standard 55. (W. U. Oxford Brookes University, Ed.) Moving Thermal Comfort Standards Into the 21st Century. Retrieved from http://web.stanford.edu/group/narratives/classes

[49] Moss, K. J. (2006). Energy Management in Buildings. New York: Taylor \& Francis.

[50] ASHRAE. Ventilation for Acceptable Indoor Air Quality. ASHRAE Handbook, 62.1-2013.

[51] Canadian Manufacturers \& Exporters. (2010). Advancing opportunity in Ontario industrial and manufacturing sector. Mississauga, Canada: Canada Manufacturers \& Exporters.

[52] Davis, G. Gray. (2002, July). California Standard Practice Manual: Economic Analysis of Demand-Side Programs and Projects. California, USA. 
[53] Eclipse Combustion. (n.d.). Curing Powder Coatings with Gas-Fired Equipment [Brochure]. Retrieved from http://www.genesyscombustion.com/whitepages-421.pdf

[54] Richard J. Reed. North American Combustion Handbook, $3^{\text {rd }}$ ed. Vol I, Cleveland: North American Manufacturing Co., 1968.

[55] Morroson, P., \& Naden, D. (2013). Process oven. Retrieved October 22, 2014, from https://www.enbridgegas.com: https://www.enbridgegas.com/businesses/assets/docs

[56] McLean, G. (2005). Direct-gas-fired air heating system. Hastings HVAC, Inc. Retrieved from http://www.hastingshvac.com/file/Direct\%20gas-Fired\%20Heating\%20System.pdf

[57] Talbert, R. (1994). Convection Curing Equipment: Understanding gas-fired convection curing equipment for powder coating. Powder Coating. Retrieved from http://infohouse.p2ric.org/ref/39/38957.pdf

[58] Goetzman,J. (n.d). Fundamental of Pressure and Temperature Measurement. Center Point Energy. 1111 Louisiana, Texas 77002.

[59] Canada, N. R. (2008). Improving energy performance in Canada. Office of Energy Efficiency. Ottawa ON K1G 6S1: Natural Resources Canada. Retrieved from http//www.oee.nrcan.gc.ca/publications. ISBN 978-1-100-11432-3

[60] Thollan, P., \& D, E. (2010). An energy efficiency program for Swedish industrial small-and medium-sized enterprises. Linkoping, Sweden: Elsevier Science B.V., Amsterdam. Retrieved from http://urn.kb.se/resolve?urn=urn:nbn:se:liu:diva-58532

[61] Banyard, C. (1983). Energy audits, property management. Emerald Insight. Vol.1, Iss 1 pp. 26-29. Retrieved from http://www.emeraldinsight.com/doi/abs/10.1108/eb006544

[62] Standard for Ovens and Furnaces (NFPA 86). (2007). National Fire Protection Association. Retrieved from http://www.nfpa.org/codes-and-standards/document-informationpages? mode $=$ code $\&$ code $=86$

[63] Public safety first. (n.d.). Technical standard and safety authority. Retrieved from http://www.tssa.org

[64] Oxford Dictionary. (n.d.). Oxford online dictionary. Retrieved from http://www.oxforddictionaries.com/definition/english/summer

[65] Government of Canada. (2015). Before you arrived: get to know Canada, typical featuture of seasons. Retrieved from http://www.cic.gc.ca/english/newcomers/before-seasons-typical. asap, August 14, 2015.

[66] Ontario Energy Board. (n.d.). Weather Normalization for Total Utility Load. Retrieved from http://www.ontarioenergyboard.ca/documents/cases/EB-2005-0317. 
[67] Avina, J. (2012). An Introduction to Utility Bill Weather Normalization for Energy Contractors. Retrieved from http://www.abraxasenergy.com/articles/intro-weathernormalization-contractors/

[68] Fels, M. F., Kissock, K., A, Michelle., Marean., \& R, Cathey. (1995). PRISM (Advance Version 1.0) User Guide. Princeton University: Centre for Energy and Environmental Studies. New Jersey.

[69] Environment Canada. (n.d.). Ontario-weather condition and forecast by location. Retrieved from http://www.weather.gc.ca/city/pages/on-143_metric_e

[70] Fels, M. F., Rachlin, J., \& Socolow, R. H. (1986). Seasonality of non-heating consumption and its effect on PRISM results. Energy and Buildings. Pages 139-148.

[71] Finch, G., Burnett, E., \& Knowles, W. (2010). Energy Consumption in Mid and High Rise Residential Buildings in British Columbia, Portland.

[72] Paulus, M.T., Claridge, D.E., \& Culp, C. (2014). Algorithms for automating the selection of a temperature dependent change point model. Energy and Buildings. 87(2015)95-104.

[73] Eto, H. J. (n.d.). A comparison of weather normalization technique for commercial buildings energy use. Retrieved from http://www.ornl.gov/sci/buildings/2012.

[74] ASHRAE, Guideline 14-2002, Measurement of energy and demand savings, 2002.

[75] Fels, M. F. (1086). PRISM: an introduction. Energy Build. 5-18.

[76] 2009 ASHRAE Handbook- Fundamental. (n.d.). Climatic design information. Retrieved from http://www.ecop.rpi.edu/hartford/

[77] Tapia, S., \& J.A. Rio, J.A., (2011). One temperature model for effective ovens, Classical physics, Cornel university library. Retrieved from http://www.arxiv.org/abs/1109.0664

[78] Hong, S., Wen, C., He, J., Gan, F., \& Yuh, H., (2009). Adsorption thermodynamics of Methylene Blue onto bentonite. Journal of Hazardous Materials, doi: 10.1016/j.jhazmat.2009.01.014.

[79] Apraci, V. (2001). Thermal Deformation: From Thermodynamics to Heat Transfer. Journal of Heat Transfer, from http://heattransfer.asmedigitalcollection.asme.org.ezproxy.lib.ryerson.ca/article.aspx?articleid=1 445148, doi: 10:1115/1.1379953

[80] Eclipse guide to infra-red heating. (1992). Curing powder coating with gas-fired equipment. Published SP-421, Eclipse combustion, Rockford, IL. 
[81] Hangzhou color powder coating Equipment Co., Ltd. (n.d) Retrieved from http://www.powder-coatingline.com/china-

lpg_tank_powder_coating_line_industrial_spray_painting_equipment_1_6_m_min_custom-

1180042.html

[82] Bierma, T.J., \& Marsch, D. (2008). Material and Energy Efficiency in SMEs. University of Illinois, Normal, Illinois.

[83] Acomi, N., Acomi, O. C., \& Ghita, S., (2008). The Energy Efficiency Operational Index An instrument for the Marine Pollution Control. Recent Advances in Energy, Environment, Economics and Technological Innovation, ISBN: 978-960-474-343-8.

[84] IMO, Interim guidelines for voluntary ship $\mathrm{CO}_{2}$ emission indexing for use in trials,

MEPC.1/Circ.471.CO 2, 2005.

[85] IEA, (2013). IEA statistics. $\mathrm{CO}_{2}$ emissions from fuel combustion highlights. Retrieved from http://www.iea.org/publications/freepublications/publication/co2emissionsfromfuelcombustionhi ghlights2013.pdf

[86] City of Toronto, Environment and Energy division. (2014). Annual energy consumption and greenhouse gas emission report. Retrieved from http://www.toronto.ca/city\%20\%of 20Toronto/Environment\%20\%20Energy/action\%20Plans,

20\%Policies\%20\&Research?PDFs/2012_energy_consumption_HGH_emission\%20report.pdf

[87] Putman Media. (2015). Sustainable operations area efficiency. Retrieved from www.sustainableplant.com/topic/efficient

[88] Mazda (n.d). Reduced total $\mathrm{CO}_{2}$ emissions from Mazda's four principal domestic plants by 42.6\% compared with FY March 1991 levels. Retrieved from http://www2.mazda.com/en/csr/download/pdf/2012/2012_s_p48.pdf

[89] Ontario. Ministry of Labour (n.d.), Public holiday; Retrieved from http://www.labour.gov.on.ca/english/es/pubs/guide/publicholidays.php

[90] Statutory Holidays Canada, (n.d.): Canadian statutory holidays. Dates and information about holidays in Canada. Retrieved from http://www.statutoryholidays.com/ontario.php

[91] Calendar for year 2013 (n.d.): Timeanddate.com: Retrieved from http://www.timeanddate.com/calendar/?country

[92] Gray, D. (2002). California Standard Practice Manual: Economic Analysis of Demand-Side Programs and Projects. Published by governor's office of planning and research, state of California. 
[93] Gray, W., \& Tatiana, K. (2009). Applying the total resource cost test to conservation and demand management initiatives of local electricity distribution companies in Ontario: Assessment and recommendations for reform. Faculty of Environmental Studies, York University, Canada

[94] Investopedia. (n.d.). Investopedia online dictionary. Retrieved from http://www.investopedia.com/terms/n/npv.asp

[95] The financial-dictionary. (n.d.). Retrieved from http://financialdictionary.thefreedictionary.com/Cost-Benefit+Ratio

[96] Mind Tools Ltd. (n.d.). Cost-Benefit Analysis: Deciding, Quantitatively, Whether to go Ahead. Retrieved from http://www.mindtools.com/pages/article/newTED_08.htm

[97] Ontario Energy Board. (2014). Natural Gas Demand Side Management Summary Report 2012 Results. Toronto: Ontario Energy Board.

[98] Benchmarking. (n.d.). In Education Portal's online dictionary. Retrieved from http://education-portal.com/academy/lesson/what-is-benchmarking-definition

[99] Ribeiro, L., \& Cabral, J.A. (2006). A Benchmarking Methodology for Metalcasting Industry. Benchmarking: An International Journal, 13, 23-35. doi: 10.1108/14635770610644556

[100] Morroson, P., \& Naden, D. (2013). Process oven. Retrieved October 22, 2014, from https://www.enbridgegas.com: https://www.enbridgegas.com/businesses/assets/docs

[101] Turner, Wayne C. (2006). Energy Managemnt Handbook. The Fairmon Press, Inc, 700 Indiana Trail, Liburn, GA 30047: TJ163.2.T87 2006

[102] City of Toronto, Environment and Energy division. (2014). Annual energy consumption and greenhouse gas emission report. Retrieved from http://www.toronto.ca/city\%20\% of 20Toronto/Environment\%20\%20Energy/action\%20Plans, 20\%Policies\%20\&Research?PDFs/2012_energy_consumption_HGH_emission\%20report.pdf

[103] Putman Media. (2015). Sustainable operations area efficiency. Retrieved from www.sustainableplant.com/topic/efficient dated March 13' 2015].

[104] Mazda (n.d). Reduced total CO2 emissions from Mazda's four principle domestic plants by $42.6 \%$ compared with FY March 1991 levels. Retrieved from http://www2.mazda.com/en/csr/download/pdf/2012/2012_s_p48.pdf dated March 13' 2015].

[105] Kasinoff, H. (2002). Oven exhaust gas oxygen sending arrangement and related control circuit and methods. CA2352648 A1, Retrieved from https://www.google.com/patient/CA2352648A1?cl = en 
[106] Ontario. Ministry of Labour (n.d.), Public holiday; Retrieved from http://www.labour.gov.on.ca/english/es/pubs/guide/publicholidays.php

[107] Statutory Holidays Canada, (n.d.): Canadian statutory holidays. Dates and information about holidays in Canada. Retrieved from http://www.statutoryholidays.com/ontario.php

[108] Calendar for year 2013 (n.d.): Timeanddate.com: Retrieved from http://www.timeanddate.com/calendar/?country

[109] Carpenter, k. and K, Kissoack. (n.d.). Energy efficiency process heating: Insulation and thermal mass. University of Dayton, 300 College Park, Dayton, OH 45469-02210. Retrieved fromhttps://www.udayton.edu/engineering/centers/industrial_assessment/resources/docs/pdf/Insu 1ThermMass_SAE2005_draft_.pdf

[110] U.S. Department of Energy. (2002). Process heat tip sheet \# 2. Office of Industrial Technologies Energy Efficiency and Renewable Energy, Washington DC, 20585-0121

[111] Kaynakli, O. (2011). Parametric investigation of optimum thermal insulation thickness for external wall. Energies, 913-927; doi: 10.3390/en4060913

[112] Bolatturk, A. (2006). Determination of optimum insulation thickness for building walls with respect to various fuels and climate zones in Turkey. Applied thermal engineering, 26, 1301-1309, ISSN-1333-1124

[113] Aytac, A., \& Aksoy, U.T. (2006). The relation between optimum insulation thickness and heating cost on external walls for energy savings. Journal of faculty of engineering and architecture, Gazi University, 21, 753-758

[114] Johnson Controls Company. (2006). Solution-energy series reducing AHU energy consumption. P.O. Box 1592, York, Pennsylvania USA 17405-1692 